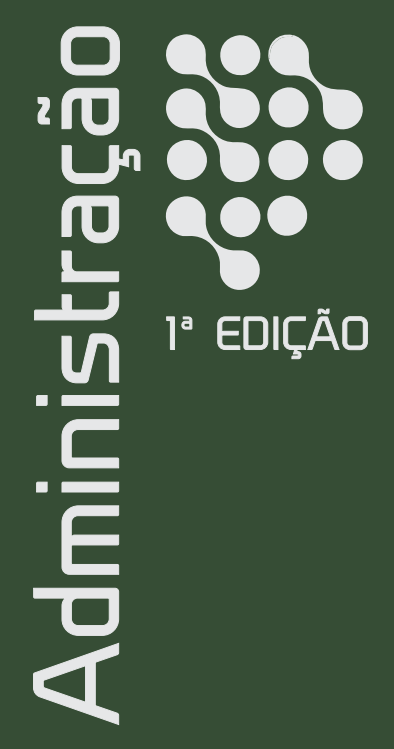

GESTÃO

\title{
ORGANIZACIONAL: REALIDADE ATUAL E PERSPECTIVAS FUTURAS
}

ORGANIZAÇĀO
MARIA APARECIDA FERNANDES

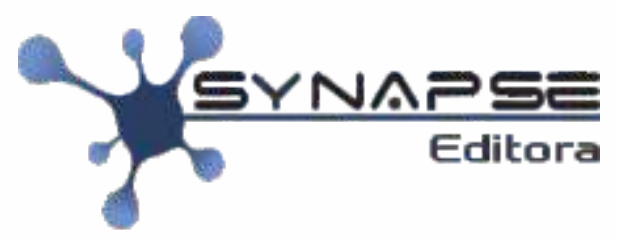

Compartilhando conhecimento 
Editor Chefe

Msc Washington Moreira Cavalcanti

Organizador

Maria Aparecida Fernandes

Conselho Editorial

Msc Lais Brito Cangussu

Msc Rômulo Maziero

Msc Jorge dos Santos Mariano

Dr Jean Canestri

Msc Elias Rocha Gonçalves Júnior

Projeto Gráfico e Diagramação

Departamento de arte Synapse Editora

Edição de Arte Maria Aparecida Fernandes

Revisão

Os Autores
2021 by Synapse Editora

Copyright (c) Synapse Editora

Copyright do Texto (c) 2021 Os autores

Copyright da Edição (c) 2021 Synapse Editora

Direitos para esta edição cedidos à

Synapse Editora pelos autores.

O conteúdo dos artigos e seus dados em sua forma, correção e confiabilidade são de responsabilidade exclusiva dos autores, inclusive não representam necessariamente a posição oficial da Synapse Editora.

Permitido o download da obra e o compartilhamento desde que sejam atribuídos créditos aos autores, mas sem a possibilidade de alterá-la de nenhuma forma ou utilizá-la para fins comerciais.

A Synapse Editora não se responsabiliza por eventuais mudanças ocorridas nos endereços convencionais ou eletrônicos citados nesta obra.

Todos os manuscritos foram previamente submetidos à avaliação por parte dos membros do Conselho Editorial desta Editora e pareceristas convidados, tendo sido aprovados para a publicação.

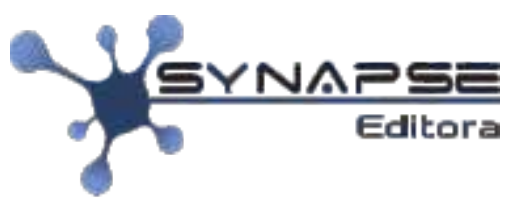

Compartilhando conhecimento

2021 


\section{F363g Fernandes, Maria Aparecida}

Gestão Organizacional: Realidade atual e perspectivas futuras Organizadora: Maria Aparecida Fernandes

Belo Horizonte, MG: Synapse Editora, 2021, 207 p.

Formato: PDF

Modo de acesso: World Wide Web.

Inclui bibliografia

ISBN: 978-65-88890-11-0

DOI: doi.org/10.36599/editpa-2021_gorap

1. Gestão Organizacional. 2. Ambiente Organizacional. 3. Gestão Empresarial. 4. Gestão Pública

I. Gestão Organizacional: Realidade atual e perspectivas futuras

SYNAPSE EDITORA

Belo Horizonte - Minas Gerais

CNPJ: 20.874.438/0001-06

Tel: + 5531 98264-1586

www.editorasynapse.org

editorasynapse@gmail.com

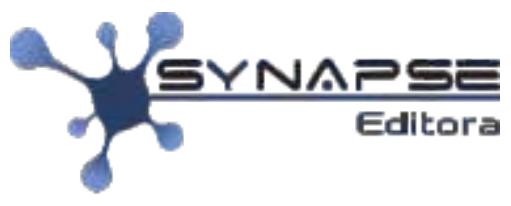

Compartillhando conhecimento

2021 


\section{Apresentação}

Atualmente, uma das questões preocupantes para as Organizações Corporativas são fatores relacionados ao gerenciamento das corporações como a responsabilidade social, a motivação de seus colaboradores, a gestão de processos e o aprendizado organizacional. Grande parte dessas questões estão associadas a gestão da qualidade interagindo com os sistemas inteligentes e a gestão da inovação.

A gestão é um processo contínuo de alocação de recursos de uma organização (recursos humanos e econômicos) por funções gerenciais típicas (planejamento, organização, motivação e controle) com o objetivo de alcançar metas declaradas, ou seja, como utilizar as melhores práticas para se alcançar o melhor da Gestão Organizacional.

Neste livro são apresentadas pesquisas relevantes e atuais que permitem dialogar com a gestão organizacional, seja ela privada ou pública, as tendências e diagnósticos organizacionais, análise de riscos, gestão integrada, metodologia PDCA, assim como, a inovação dentro das organizações.

Maria Aparecida Fernandes

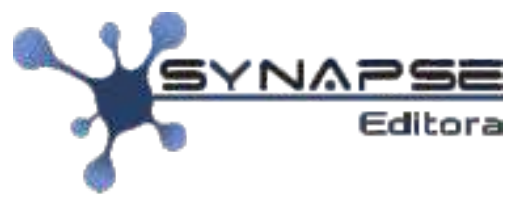

Compartillhando conhecimento

2021 


\title{
Sumário
}

CAPÍTULO 1

RESPONSABILIDADE SOCIOAMBIENTAL: O CASO DE UMA INDÚSTRIA DE COSMÉTICOS DO INTERIOR DE MINAS GERAIS, BRASIL

\author{
Homero Domingues \\ Talles Jefferson Valentim \\ Gustavo Martins do Carmo Miranda \\ DOI doi.org/10.36599/editpa-2021_gorap-001
}

\section{CAPÍTULO 2}

O NIVEL DE MOTIVAÇÃO/SATISFAÇÃO E A RESPECTIVA INFLUÊNCIA NA QUALIDADE DO TRABALHO DOCENTE A PARTIR DA ANÁLISE LINGUÍSTICO-DISCURSIVA DA CONSTRUÇÃO DO ETHOS: UM ESTUDO DE CASO EM UMA UNIVERSIDADE FEDERAL BRASILEIRA

Geúno Bruno Vieira Soares

Priscilla Chantal Duarte Silva

Ricardo Luiz Perez Teixeira

DOI doi.org/10.36599/editpa-2021_gorap-002

\section{CAPÍTULO 3}

IDENTIFICAÇÃO DE FALHAS DE GESTÃO E ORGANIZAÇÃO EM OBRAS DO MUNICÍPIO DE POMBAL-PB COM BASE NOS PRINCÍPIOS DA CONSTRUÇÃO ENXUTA: UM ESTUDO DE CASO

$\begin{array}{ll}\text { Raquel Ferreira do Nascimento } & \text { Cibelle Guimarães Silva Severo } \\ \text { Leonardo de Souza Dias } & \text { Danylo de Andrade Lima } \\ \text { Heberton Linhares Damaceno } & \text { Maelle Guedes Passos } \\ \text { Alice Vitória Serafim Beserra } & \text { GeovanyFerreira Barrozo } \\ \text { Náthaly Bernardo Sousa } & \text { Bianca Anacleto Araújo de Sousa } \\ \text { Thomas Mayck Wanderley Melo } & \text { Francisco Ygor Moreira Menezes } \\ \text { Dol doi.org/10.36599/editpa-2021_gorap-003 }\end{array}$

CAPÍTULO 4

O USO DA SIMULAÇÃO NO PROCESSO DE TOMADA DE DECISÃO EM UMA EMPRESA DO SETOR VAREJISTA

\author{
lochane Garcia Guimarãe \\ Leonardo Marques Caires \\ Virginia Thomasi
}

DOI doi.org/10.36599/editpa-2021_gorap-004

\section{CAPÍTULO 5}

GESTÃO DE PROCESSOS NO SETOR PÚBLICO:

UM ESTUDO NA UNIVERSIDADE FEDERAL DO TOCANTINS

Jordana Teixeira de Melo Dias

Helga Midori Iwamoto

DOI doi.org/10.36599/editpa-2021_gorap-005

\section{CAPÍTULO 6}

A CONTRIBUIÇÃO DA PRÁTICA PARA A PESQUISA SOBRE O USO DAS MÍDIAS SOCIAIS NA APRENDIZAGEM EM ORGANIZAÇÕES

\footnotetext{
Mírian Assumpção e Lima

Helton Cristian de Paula

Wellington Tavares

Lelis Maia de Brito

DOI doi.org/10.36599/editpa-2021_gorap-006
} 


\section{Sumário}

CAPÍTULO 7

CERTIFICAÇÃO DE QUALIDADE COMO INOVAÇÃO NA GESTÃO DE SERVIÇOS DE SAÚDE: EXPERIÊNCIA DO CEARÁ.

Flavianne Santos Soares Oliveira

Maria Ludimila Arruda Frota Rocha

Lady Diana Arruda Mota

DOI doi.org/10.36599/editpa-2021_gorap-007

CAPÍTULO 8

SISTEMAS INTELIGENTES DE TRANSPORTES E SUAS APLICAÇÕES PARA O AUMENTO DA EFICIÊNCIA NO TRANSPORTE DE CARGAS: UMA REVISÃO DA LITERATURA.

Isabela Kopperschmidt de Oliveira

DOI doi.org/10.36599/editpa-2021_gorap-008

CAPÍTULO 9

AS BASES TEÓRICOS-CONCEITUAIS (FRAMEWORK) DE AVALIAÇÃO DE DESEMPENHO E RESULTADOS APLICADOS NAS INSTITUIÇÕES DE SAÚDE NO BRASIL

Galba Freire Moita

Allan Claudius Queiroz Barbosa

DOI doi.org/10.36599/editpa-2021_gorap-009

CAPÍTULO 10

MODELOS E INSTRUMENTOS DE AVALIAÇÃO DE QUALIDADE E SATISFAÇÃO NA

EXPERIÊNCIA DE USUÁRIOS DE SAÚDE NO BRASIL

Galba Freire Moita

Zulmira Maria de Araújo Hartz

DOIdoi.org/10.36599/editpa-2021_gorap-010

CAPÍTULO 11

O PROCESSO DE ADESÃO AO PROGRAMA DA QUALIDADE NO SERVIÇO PÚBLICO (PQSP) E A QUALIDADE NO ATENDIMENTO EM SAÚDE, EM FUNÇÃO DA EXCELÊNCIA

Priscila Marinho da Silva

DOI doi.org/10.36599/editpa-2021_gorap-011

CAPÍTULO 12

GESTÃO DA INOVAÇÃO, TEORIAS E PRÁTICAS APLICÁVEIS

ÀS AÇÕES EMPRESARIAIS

Washington Moreira Cavalcanti

Maria aparecida Fernandes

DOI doi.org/10.36599/editpa-2021_gorap-012 


\title{
RESPONSABILIDADE SOCIOAMBIENTAL: O CASO DE UMA INDÚSTRIA DE COSMÉTICOS DO INTERIOR DE MINAS GERAIS, BRASIL.
}

\author{
Homero Domingues \\ Faculdade Doctum de João Monlevade \\ profhomerodomingues@gmail.com \\ Talles Jefferson Valentim \\ Faculdade Doctum de João Monlevade \\ tallesjeffersonvalentim@gmail.com \\ Gustavo Martins do Carmo Miranda \\ Universidade Federal de Minas Gerais - UFMG \\ gustavmcm@gmail.com
}

\begin{abstract}
RESUMO
Nas últimas décadas, questões relacionadas à Responsabilidade Socioambiental e ao crescimento sustentável nas organizações estão sendo constantemente debatidas pela sociedade. Este estudo teve como objetivo identificar os principais projetos sociais e ambientais em uma indústria de cosméticos, bem como compreender a percepção dos moradores e beneficiários locais em relação às ações desenvolvidas pela empresa. A relevância da pesquisa está no fato da responsabilidade socioambiental ser assunto de interesse: de diversos públicos envolvidos com as organizações, sejam eles funcionários, clientes, fornecedores, gestores ou sociedade local. Para a realização do estudo foram realizadas pesquisas bibliográficas em livros e artigos sobre o tema, além de
\end{abstract}

um estudo de caso em uma indústria de cosméticos do interior de Minas Gerais, com a realização de entrevista com o gestor da empresa e a aplicação de questionário com os moradores da cidade em que está inserida a indústria de cosméticos. Por meio dessas pesquisas foi possível entender que a preservação do lucro da instituição está diretamente relacionada aos investimentos em sustentabilidade apresentados pela empresa. Além disso, foi possível entender a percepção da comunidade local quanto aos projetos socioambientais implantados pela organização.

\section{Palavras-chave:}

Sustentabilidade; Ambiente organizacional; Crescimento sustentável; Comunidade local.

\begin{abstract}
In recent decades, issues related to Social and Environmental Responsibility and sustainable growth in organizations have been constantly debated by society. This study aimed to identify the main social and environmental projects in a cosmetics industry, as well as to understand the perception of local residents and beneficiaries regarding the actions developed by the company. The relevance of the research lies in the fact that social and environmental responsibility is a matter of interest to various publics involved with organizations, whether employees, customers, suppliers, managers or local society. To carry out the study were conducted bibliographic searches in books and articles on the subject, as well as a case study in a cosmetics industry in the interior of Minas Gerais, with
\end{abstract}

interviews with the manager of the company and the application of a questionnaire with residents of the city where the cosmetics industry is located. Through these researches it was possible to understand that the preservation of the institution's profit is directly related to the sustainability investments presented by the company. In addition, it was possible to understand the perception of the local community regarding the social and environmental projects implemented by the organization.

\section{Keywords:}

Sustainability; Organizational environment; Sustainable growth; Local community. 


\section{INTRODUÇÃO}

Nos últimos anos, as questões referentes à Responsabilidade Socioambiental têm ganhado espaço nas mídias e, sobretudo nas ações das organizações e de seus gestores. Porém, percebe-se que no Brasil as ações empresariais ainda são incipientes no que se refere à sustentabilidade.

Para uma organização ser considerada sustentável, é necessário que atenda às suas necessidades do presente, sem comprometer os recursos que garantirão o desenvolvimento e o bem-estar das gerações futuras. Deve, sobretudo, preocupar-se com todas as variáveis e pessoas envolvidas em seus processos, trabalhando para atingir as metas econômicas, sem perder de vista os objetivos da sociedade em geral, notadamente a preservação do meio ambiente.

A visão clássica da empresa pode incorporar em seu planejamento estratégico as questões socioambientais, além da obrigação legal, eleva os custos e reduz o lucro das empresas. Esse posicionamento é uma estratégia de curto prazo que não se sustenta diante do conceito de empresa socialmente responsável. Para que haja perpetuação da política de responsabilidade socioambiental, trabalha-se com a visão de lucro a longo prazo, como forma de alcançar os objetivos empresariais (Borger, 2013).

Diante do exposto, questiona-se: como uma empresa pode visar ao lucro e,concomitantemente, implementar medidas de responsabilidade socioambiental? Nesse sentido, o presente artigo tem como objetivo geral identificar os principais projetos sociais e ambientais implantados por uma indústria de cosméticos, bem como compreender a percepção dos moradores e beneficiários locais em relação às ações desenvolvidas pela indústria e entender como esses investimentos geram lucros para a organização. Além disso, os objetivos específicos desse estudo são: caracterizar os diferentes projetos sociais e ambientais desenvolvidos pela indústria de cosméticos; descrever a percepção dos moradores e dos beneficiários quanto aos resultados gerados pelos projetos; identificar como a empresa consegue conciliar responsabilidade socioambiental com a preservação de seu lucro; além de apresentar para a empresa os resultados da pesquisa e propor algumas ações para continuidade dos projetos. Portanto, a responsabilidade socioambiental é um assunto do interesse de diversos públicos, o que atribui relevância a este estudo. Todos os indivíduos ligados às organizações - sejam eles funcionários, clientes, fornecedores, gestores e sociedade local - são beneficiados, direta ou indiretamente, por estudos que visem a embasar e fomentar ações empresariais voltadas à preservação do meio ambiente e pelo desenvolvimento de projetos sociais.

Para atingir os objetivos propostos neste trabalho, a pesquisa divide-se em duas etapas. A primeira tem uma abordagem qualitativa, de caráter exploratório, para aprofundamento do tema por meio do levantamento bibliográfico em livros e artigos especializados no tema. Essa parte também é constituída por entrevista semiestruturadas com o principal gestor da empresa e por observação de dados secundários em alguns órgãos governais responsáveis pela área de Responsabilidade Socioambiental. A segunda etapa tem caráter descritivo e uma abordagem quantitativa, com o fim de coletar dados sobre a percepção da sociedade local acerca dos projetos socioambientais implementados por uma indústria de cosméticos do interior de Minas Gerais. 
O artigo encontra-se dividido da seguinte forma: após essa breve introdução, é abordada o referencial teórico que apresenta autores que fazem considerações a respeito da contextualização histórica da responsabilidade socioambiental, do conceito de responsabilidade socioambiental empresarial, dos benefícios e vantagens da implantação da responsabilidade sócio empresarial dentro das organizações, além da abordagem sobre indicadores de desempenho. A próxima seção faz menção à caracterização da organização onde será realizado o estudo de caso. Em seguida, apresenta-se a metodologia utilizada na realização do trabalho. Logo após, aborda-se a pesquisa e a análise dos dados apurados durante a realização do trabalho. Encerra-se o trabalho com as considerações finais.

\section{Contextualização Histórica da Responsabilidade Socioambiental}

De acordo com Dias (2017), os consumidores começaram a ter consciência das questões socioambientais durante a segunda metade do século $X X$, essa conscientização ocorreu ao mesmo tempo em que cresceram de forma considerada as denúncias a respeito dos impactos ambientais que as atividades organizacionais estavam causando no meio ambiente.

Reis \& Medeiros (2007) acrescentam que, a Responsabilidade Social das Empresas (RSE) teve o seu início nos anos de 1960 nos Estados Unidos da América (EUA), motivada pela busca por maior consciência de segmentos da sociedade em relação à responsabilidade das empresas na preservação do meio ambiente e dos direitos dos consumidores.

Diante de um contexto econômico caracterizado por uma rígida postura dos consumidores que possuem uma percepção direcionada à expectativa de interagir com organizações que sejam éticas, com uma imagem institucional de crédito com o mercado, e com empresas que sejam ecologicamente responsáveis, têm-se desenvolvido nas empresas uma visão voltada para a gestão da responsabilidade social (Tachizawa, 2004).

No Brasil, no ano de 1998, a Confederação Nacional da Indústria (CNI) elaborou a Declaração de Princípios da Indústria para o Desenvolvimento Sustentável. Essa declaração continha normas que visavam ao crescimento empresarial de forma simultânea ao desenvolvimento social e ambiental. A publicação do documento do CNI, como considera Dias (2017) foi considerada como um grande passo para que as empresas colocassem em seu planejamento maneiras de realizar as suas atividades de uma forma que não gere um impacto negativo no meio ambiente e contribua para o desenvolvimento da sociedade em que está inserida.

\subsection{Responsabilidade Socioambiental Empresarial}

De acordo com Tachizawa (2002), a responsabilidade socioambiental quando implementada nas organizações agregam valor para seus clientes e são fatores que servem como diferencial competitivo para a organização. Nesse sentido as organizações devem implantar a responsabilidade socioambiental em suas atividades e fazer com que todos os envolvidos e impactados pelas ações percebam as atitudes que equilibram o crescimento econômico com o desenvolvimento da sociedade e do meio ambiente.

Percebe-se entre as empresas com destaque em ações de responsabilidade socioambiental benefícios como uma melhor imagem institucional, melhor aproveitamentodos recursos e acesso a mercado de capitais, etc. Benefícios esses que podem ajudar em uma melhor competitividade no 
mercado, formados, na maioria das vezes, por uma elevada rivalidade entre os competidores. Sendo assim, Lilian Aligleri; Luiz Aligleri \& Krunglianskas (2009), mencionam a competitividade no novo contexto empresarial e segundo os autores:

A revolução tecnológica e o mundo cada vez mais globalizado estão gerando transformações e, consequentemente, um novo contexto competitivo empresarial. Rapidez nas informações, maior concorrência e comunicação instantânea ocasionaram uma nova realidade para as organizações. Preço, produto de qualidade, notável serviço ao cliente $e$ controle de custos são condições mínimas para a sobrevivência das empresas e isoladamente não impulsionam o crescimento da organização (Aligleri, Aligleri \& Kruglianskas, 2009, p. 4).

Esses autores também revelam que o macroambiente tem impostos novos desafios para as organizações, tais como: maior valorização por comportamentos ecologicamente corretos, busca por qualidade de vida no trabalho, postura ética e diversidade da força de trabalho devido aos novos valores sociais, cultura e estilo de vida.

Diante do cenário atual, com o aumento da competitividade e a preocupação das empresas em manter os clientes e/ou conquistar o mercado consumidor, torna-se necessária a adoção de práticas de responsabilidade socioambiental, o que pode trazer resultados positivos para as organizações.

Responsabilidade Socioambiental diz respeito à postura adotada por uma empresa no sentido de criar melhoria contínua para a sociedade e o meio ambiente. Empresas de todos os segmentos, por meio da aplicação da responsabilidade socioambiental em suas atividades buscam formas de ressarcir todo o público envolvido e que será afetado pelos processos das organizações, com práticas que contribuam com a melhoria contínua do meio ambiente e consequentemente tragam uma melhor qualidade de vida para as pessoas (Lacerda \& Moura, 2016).

Pode inferir que as empresas que não traçarem metas estratégicas em seus negócios para conquistar a competitividade, não sobreviverão em meio àquelas organizações que visam ao alinhamento da teoria com a prática. Nota-se que, em mundo onde a disputa por um espaço no mercado está cada vez mais acirrada, apenas as empresas que realmente implantarem estratégias que de fato contribuíram para colocar em prática o exercício da responsabilidade socioambiental, irão ter continuidade no mercado empresarial. Desse modo, consideramos demodo semelhante ao que afirma Tachizawa (2004), é fundamental que essas empresas sejam socialmente responsáveis e adotem estratégias para um desenvolvimento sustentável e que atendam aos aspectos legais.

\subsection{Desenvolvimento Sustentável}

Segundo Dias (2017), o desenvolvimento sustentável dentro das organizações é representado pelas dimensões econômica, social e ambiental. Levando-se em conta a dimensão econômica, ser uma organização sustentável é obter o retorno esperado através do investimento realizado na implantação da organização. Já na dimensão social a organização deve adotar formas de proporcionar para todos os envolvidos no contexto organizacional melhores condições de vida. Por fim, a dimensão ambiental aponta que a organização deve colocar em prática ações que contribuam para o desenvolvimento ambiental, deve obter uma postura de responsabilidade ambiental. 
Donaire (2016) corrobora que, o desenvolvimento sustentável vai além da antiga visão que as organizações tinham a respeito do motivo de sua existência, que era simplesmente auferir lucro através da produção de bens e serviços, com a nova visão, para ser considerada uma empresa sustentável, a organização além de obter lucro deve preocupar-se com a forma como modifica o meio ambiente e a sociedade ao qual está inserida.

Para Tachizawa (2007), a busca pela sustentabilidade e consequentemente o desenvolvimento sustentável por parte das organizações está se tornando uma realidade para o mundo dos negócios, além de ser essencial para o crescimento econômico empresarial, a busca pelo desenvolvimento sustentável é fator de vantagem competitiva para a organização. O autor acrescenta que, questões sociais e ambientais, em equilíbrio com as questões econômicas são essenciais para o êxito e a sobrevivência dos negócios.

Para tanto, as empresas podem se valer de indicadores que auxiliam na identificação do grau de responsabilidade de suas empresas. Na literatura sobre o assunto encontram-se várias ferramentas de indicadores de sustentabilidade que serão abordadas a seguir.

\subsection{Indicadores de Responsabilidade Socioambiental}

Segundo Martins \& Candido (2008), os indicadores de responsabilidade socioambiental (RSA) são instrumentos utilizados pelas empresas a fim de direcionar suas estratégias em busca da vantagem competitiva. Os indicadores constituem importantescritérios para orientar a gestão e o planejamento de políticas e ações que podem ser desenvolvidas pelas empresas.

Nas literaturas sobre o tema, encontram-se diversos modelos de avaliação de RSA que podem ser utilizados pelas organizações e que são adotados em vários países. Para tanto, muitas organizações utilizam desses indicadores que acompanham e controlam as práticas e estratégias empresariais para obter competitividade e lucratividade.

O tema indicador de desempenho em RSA, no Brasil, teve o seu início, em 1997, com lançamento do modelo de Balanço Social, por Betinho, do Instituto Brasileiro de Análises Sociais e Econômicas (IBASE), considerado um dos primeiros modelos utilizados no Brasil. Na mesma época, em 1998, houve também a criação do Instituto Ethos de Responsabilidade Social, pelo empresário Oded Grajew (Rabelo \& Silva, 2011).

Segundo Godoy et al. (2007), o Balanço Social leva em consideração os principais indicadores de desempenho econômico, social e ambiental das empresas. Ele pode ser considerado um meio de ampliar a comunicação com seus diversos públicos de interesse: acionistas, consumidores/clientes, comunidade vizinha, funcionários, fornecedores, governo, organizações não governamentais, mercado financeiro e sociedade.

O Instituto Ethos de Responsabilidade Social utiliza de um conjunto composto de quatro dimensões, sendo: visão e estratégia; governança e gestão; ambiental; e social. Os Indicadores Ethos têm como foco avaliar o quanto a sustentabilidade e a responsabilidade social têm sido incorporadas nos negócios, auxiliando a definição de estratégias, políticas e processos (Botelho et al, 2015).

Segundo Botelho et al. (2015), outro indicador muito utilizado em nível mundial, refere-se aos relatórios da Global Reporting Initiative (GRI), uma organização sem fins lucrativos, criada em 1997 por meio de uma ação conjunta da Coalizition for Environmentally Responsible (CERES) e do Programa 
das Nações Unidas para o Meio Ambiente (PNUMA). A finalidade dessa Organização Não Governamental (ONG) é contribuir para a melhoria dos relatórios de sustentabilidade publicados pelas empresas com maior qualidade, rigor e aplicação global, a fim de tornar os relatórios internacionalmente harmônicos. Esses relatórios devem ser elaborados com total transparência, abrangência, relevância, neutralidade, exatidão, objetividade e facilidade de compreensão.

O GRI utiliza de uma guia de apresentação com os principais indicadores de desempenho organizado pelas dimensões: econômica, social e ambiental (Global Reporting Initiative, 2015).

O Global Reporting Initiative (GRI) é formado por uma rede de peritos erepresentantes de diversos setores da sociedade (empresas, organizações não governamentais, peritos, agências governamentais, entre outros), presentes em mais de 40 países ao redor do mundo. Esses profissionais participam em grupos de trabalho e órgãos de governança do GRI e determinam as diretrizes do GRI para a realização de relatórios de sustentabilidade com a constante participação de diversas partes interessadas (Hourneaux, Corrêa \& Gomes, 2010).

Considerando um índice como simplesmente um indicador de alta categoria, leva-se em conta o Índice de Sustentabilidade Empresarial (ISE), também como um indicador de Responsabilidade Social. De acordo com Botelho et al. (2015), o ISE avalia o desempenho das 150 empresas com as ações mais negociadas na BOVESPA - Bolsa de Valores, Mercadorias e Futuros. Essas empresas devem demonstrar desempenho em relação à gestão sustentável no Brasil e ser referência para investidores financeiros no mundo todo, que estão em busca de aplicações em empresas socialmente responsáveis, sustentáveis e rentáveis.

Outro indicador, utilizado por empresas brasileiras e de outros países refere-se ao Grupo de Reflexão e Apoio à Cidadania Empresarial - GRACE. Trata-se de uma associação, sem fins-lucrativos e exclusivamente dedicada à promoção da Responsabilidade Social Corporativa. O GRACE foi fundado em Fevereiro de 2000 por um conjunto de empresas e atualmente reúne mais de 150 empresas, das mais variadas dimensões e setores de atividade, empenhadas em aprofundar o seu papel no desenvolvimento social das pessoas e das organizações e esse grupo tem como missão: refletir, promover e desenvolver a responsabilidade social corporativa em Portugal (Grace, 2014).

Para a presente pesquisa, pretende-se utilizar o indicador GRACE, pela simplicidade e facilidade de aplicação em pequenas e médias empresas. Ibid (2014) trata das seguintes dimensões de Responsabilidade Social: a) Responsabilidade na gestão; b) Responsabilidade pelos colaboradores; c) Responsabilidade na cadeia de valor; d) Responsabilidade pela comunidade; e) Responsabilidade pelo ambiente.

\section{Caracterização da Organização}

No ano de 1989, a empresa BioExtratus Cosméticos Naturais deu início às suas atividades, na cidade de Belo Horizonte - Minas Gerais, quando os proprietários procuravam um diferencial na área de cosméticos, e além disso, buscavam produtos capazes de atender às expectativas de todos os níveis de consumidores, tanto em qualidade quanto em preço. No início do ano de 1991 surge a marca Extratus - Produtos Naturais, a primeira empresa a apostar na utilização do óleo de tutano em cosméticos capilares.Em meados de 1997, a empresa passava por uma revolução tecnológica, seus processos, mesmo que ainda timidamente, deixavam de serem artesanais para serem tecnológicos. As vendas 
aumentavam consideravelmente e a marca passava a se tornar referência para uma grande gama de clientes. Em 1998, a Extratus Produtos Naturais passou a se chamar BioExtratus Cosméticos Naturais.

Atualmente, superando os 25 anos de atuação no mercado, oferecendo emprego diretamente para mais de 500 pessoas, a empresa BioExtratus é uma organização que apresenta grande grau de satisfação por parte de seus clientes e demais envolvidos. É uma empresa que preza o crescimento sustentável e busca meios de levar benefícios a todos os públicos que são impactados por suas ações.

A BioExtratus tem como missão oferecer ao consumidor, cosméticos de alta qualidade e preço acessível, produzidos de forma sustentável, com ética e responsabilidade socioambiental. Crescer junto com nossos fornecedores, parceiros comerciais e colaboradores, ampliando a participação no mercado, através de parcerias consolidadas. Já a visão da organização é ser referência nacional na fabricação sustentável de produtos cosméticos, reconhecidos pela sua qualidade, que combinam natureza e tecnologia. Além disso, a empresa possui os seguintes valores: comportamento ético, inovação tecnológica, primazia em saúde, segurança no trabalho, meio ambiente e serviço de qualidade.

\section{Metodologia}

Quanto à natureza trata-se de uma pesquisa aplicada. Para atingir os objetivos propostos neste trabalho, a pesquisa subdividiu-se em duas etapas. A primeira etapa consiste na abordagem qualitativa, de caráter exploratório, para aprofundamento do tema em livros e artigos especializados. Segundo Lakatos \& Marconi (1991), a pesquisa bibliográfica trata-se do levantamento, seleção e documentação de toda bibliografia já publicada sobre o assunto que está sendo pesquisado em livros, enciclopédias, revistas, jornais, folhetos, boletins, monografias, teses e dissertações. Essa parte, também foi constituída por entrevista com o gestor da empresa responsável pelos projetos socioambientais.

Já a segunda etapa teve caráter descritivo e uma abordagem quantitativa, com a coleta de dados primários, entre os moradores da cidade e beneficiários dos projetos socioambientais da empresa, a fim de investigar as percepções e conhecimentos acerca desses projetos. Com referência a esse levantamento como meio da pesquisa descritiva, Gil (2002) comenta que, além da multiplicidade de tipos, os levantamentos desenvolvem-se ao longo de várias fases,abrangendo a elaboração do instrumento de coleta de dados, pré-teste do instrumento, seleção da amostra, coleta e verificação dos dados, análise e interpretação dos dados e apresentação dos resultados.

A pesquisa foi desenvolvida em uma indústria de cosméticos do interior de Minas Gerais. Qualitativamente foi realizada uma entrevista como orienta Barbetta (2011) com o principal gestor da instituição. Quantitativamente foi efetuada uma pesquisa descritiva, com uma amostragem por julgamento ${ }^{1}$.

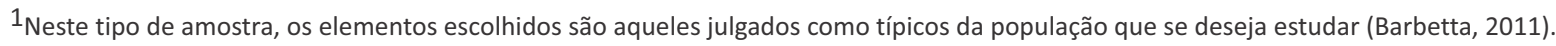




\section{Práticas de Responsabilidade Socioambiental na Indústria de Cosméticos}

Foi realizada uma entrevista com o principal gestor da instituição, com a aplicação de um questionário com perguntas estruturadas. Para tanto, foi utilizado o modelo de indicador de sustentabilidade baseado no GRACE (2014), a partir de perguntas confeccionadas com opções de resposta evidenciando a existência ou não de critérios de indicadores de RSA. No caso de não aplicação da pergunta, para a empresa pesquisada, utilizou-se a opção "não se aplica". O referido indicador utilizado trata das seguintes dimensões:

a) Responsabilidade na gestão;

b) Responsabilidade pelos colaboradores;

c) Responsabilidade na cadeia de valor;

d) Responsabilidade pela comunidade;

e) Responsabilidade pelo ambiente.

A partir da entrevista, pôde-se constatar que a BioExtratus Cosméticos Naturais possui grande preocupação nos impactos que suas ações causam para a comunidade local e ao meio ambiente.

Para tanto, no que se refere à dimensão responsabilidade na gestão, a instituição tem em seu planejamento estratégico princípios éticos que norteiam as atividades realizadas, bem como avalia e monitora a satisfação de todas as partes interessadas. Além disso, busca partilhar as informações sobre suas práticas e indicadores econômicos sociais e ambientais por meio de comunicações on-line.

No que tange à dimensão responsabilidade pelo ambiente, a instituição investe em procedimentos voltados para a redução do consumo de energia, da poluição e do consumo de água, além de desenvolver iniciativas para sensibilizar os colaboradores, fornecedores e clientes para as questões ambientais.

No tocante à dimensão responsabilidade pela comunidade, a instituição contribui para o desenvolvimento da sociedade local por meio de investimentos em ações que visam a melhorar a condição de vida das pessoas, seja por meio de patrocínios e donativos, ou pelo desenvolvimento de projetos sociais que envolvem toda a sociedade.

Já na dimensão responsabilidade pelos colaboradores, a instituição acredita que o desenvolvimento dos colaboradores, por meio do incentivo à educação, à saúde e pelo reconhecimento da capacidade profissional e pessoal das pessoas é fator preponderante para a satisfação dos funcionários no desempenho de suas atividades.

Com a relação à dimensão responsabilidade na cadeia de valor, a BioExtratus Cosméticos Naturais realiza a gestão da sua cadeia de suprimentos, de modo a incentivar seus stakeholders na busca pela qualidade e honestidade, por meio de contratos e negócios que não prejudiquem nem um lado nem o outro. Além disso, conta com ferramentas para registrar reclamações, tanto de consumidores e clientes, quanto de fornecedores.

Levando-se em conta todas essas dimensões, a instituição acredita que os investimentos realizados em responsabilidade socioambiental agregam valor à marca BioExtratus e geram uma vantagem competitiva em relação aos seus concorrentes, o que garante a maximização do lucro da empresa, além de contribuir para o desenvolvimento da sociedade e do meio ambiente ao qual está inserida. 


\subsection{Percepção da Comunidade Local em Relação à Responsabilidade Socioambiental da Empresa BioExtratus}

Foi realizada uma pesquisa descritiva a fim investigar a percepção da sociedade local com relação aos projetos sociais e ambientais desenvolvidos pela empresa. Para tanto, foi utilizada uma amostra, por acessibilidade, composta por 136 respondentes com características heterogêneas.

Quando questionado aos entrevistados sobre o significado de RSA, cerca de 98,5\% mostrou conhecimento do significado do termo. O que demonstra a importância do tema para a Sociedade local e para a empresa.

No que se refere à percepção dos entrevistados sobre os projetos sociais implantados pela empresa, $94,9 \%$ dos respondentes disseram que a organização possui projetos sociais. Deste modo, considerase que a sociedade local percebe os projetos sociais de autoria da empresa e os impactos positivos gerados por tais projetos. Por outro lado, no tocante aos projetos ambientais implantados pela organização, $75,7 \%$ dos respondentes consideram que aempresa possui projetos ambientais. Já os outros $24,3 \%$ dos entrevistados não souberam responder quando questionados se a empresa possui projetos ambientais. Diante disso, constata-se que a empresa deve trabalhar os seus projetos ambientais para que uma maior parte da sociedade perceba os projetos ambientais implantados na comunidade pela organização.

Quando solicitados aos respondentes para listarem os projetos sociais e ambientais desenvolvidos pela indústria pesquisada, foram identificados os seguintes, conforme consta no quadro (no 1) a seguir (Quadro 1):

Quadro 1: Projetos Sociais e Ambientais percebidos pelos entrevistados.

\begin{tabular}{|l|l|}
\hline \multicolumn{1}{|c|}{ PROJETOS SOCIAIS } & \multicolumn{1}{c|}{ PROJETOS AMBIENTAIS } \\
\hline Fundação BioExtratus & Estação de tratamento de afluentes \\
\hline Bateria Colibri & Fontes renováveis de energia \\
\hline Passarela BioExtratus & Gerenciamento de residuos sólidos \\
\hline Incentivo à educação & Reaproveitamento da água \\
\hline Utilização da mão de obra local & Recuperação de nascentes \\
\hline Apoio à prática de esportes e eventos culturais & Reposição da mata nativa \\
\hline Não utilização de mão de obra infantil & \\
\hline
\end{tabular}

Fonte: Elaborado pelos autores.

Nota-se que $98,5 \%$ dos entrevistados têm conhecimento da definição de responsabilidade socioambiental e, desse modo sabem identificar os projetos sociais e ambientais desenvolvidos pela instituição, além de perceberem como estes contribuem para o desenvolvimento da comunidade local.

Salienta-se que, dentro dos projetos sociais listados pelos 129 entrevistados que disseram que a indústria possui projetos sociais, a maior lembrança como projeto social desenvolvido pela empresa foi o projeto Bateria Colibri, sendo mencionado por $86,1 \%$ do público que reconhece algum projeto de cunho social desenvolvido pela BioExtratus. 
Quanto aos projetos ambientais percebidos pelos 103 entrevistados que responderam que a empresa possui projetos ambientais, a maior lembrança foi o projeto Estação de tratamento de afluentes, sendo lembrado por $40,78 \%$ do público que reconhece que a empresa apresenta projetos ambientais.

$86 \%$ dos entrevistados classificam a empresa como muito atuante no cenário da responsabilidade socioambiental. Porém, $60,3 \%$ dos respondentes não têm conhecimento sobre como a empresa define quais as ações e projetos serão implantados visando a atender às necessidades da sociedade. Estes acreditam que a instituição, antes de elaborar os projetossocioambientais, participa de discussões envolvendo os líderes da comunidade, para saber quais as áreas necessitam de apoio.

Durante a aplicação da entrevista foi questionado se a comunidade necessita de algum projeto social ou ambiental que a organização ainda não atende $61 \%$ dos entrevistados responderam que sim. Segundo esses entrevistados, a comunidade ainda é carente de alguns projetos sociais e ambientais que poderiam ser implantados pela empresa. Sendo assim, foi solicitado aos $61 \%$ dos entrevistados exemplos de projetos sociais e ambientais que poderiam ser atendidos pela empresa. Diante dessa resposta, foram identificados os seguintes projetos sociais e ambientais que podem ser implantados pela instituição, conforme consta no quadro ( $\mathrm{n}$-2) abaixo:

Quadro 2: Projetos Sociais e Ambientais sugeridos pelos entrevistados.

\begin{tabular}{|l|l|}
\hline \multicolumn{1}{|c|}{ PROJETOS SOCIAIS } & \multicolumn{1}{c|}{ PROJETOS AMBIENTAIS } \\
\hline $\begin{array}{l}\text { Incentivo à educação para todos os membros } \\
\text { da comunidade }\end{array}$ & $\begin{array}{l}\text { Projeto de reciclagem que envolve toda a } \\
\text { comunidade }\end{array}$ \\
\hline $\begin{array}{l}\text { Apoio à saúde para a comunidade e } \\
\text { investimento em lazer para os idosos }\end{array}$ & $\begin{array}{l}\text { Projeto de preservação do meio ambiente } \\
\text { extensivo à comunidade }\end{array}$ \\
\hline Projetos de apoio à arte e dança & \multicolumn{1}{c|}{} \\
\hline
\end{tabular}

Fonte: Elaborado pelos autores.

Com base na entrevista realizada, percebe-se que a BioExtratus Cosméticos Naturais contribui de forma assertiva para o desenvolvimento da comunidade local. Nota-se ainda que, 95,9\% dos entrevistados possuem uma imagem positiva da instituição, o que torna fator preponderante para a ótima relação entre a instituição e a sociedade. Contudo, $88,7 \%$ dos entrevistados acreditam que a instituição poderia investir ainda mais em áreas como a saúde da população e a conscientização de toda a comunidade nos assuntos como: reciclagem, coleta seletiva e preservação do meio ambiente.

\section{Considerações Finais}

Por meio deste estudo foi possível entender que atualmente, a maximização e preservação do lucro de toda e qualquer empresa, seja ela de pequeno, médio ou grande porte, também podem estar relacionados com as ações e projetos socioambientais que são implantados pela instituição. Nesse sentido, entende-se que o problema apresentado nesse trabalho foi entendido e solucionado, inicialmente, por meio da entrevista realizada com ogestor da BioExtratus Cosméticos Naturais e por meio da percepção da comunidade local, a respeito da contribuição que os projetos socioambientais implantados pela instituição trazem para a sociedade. 
Os objetivos do presente trabalho foram alcançados a partir de pesquisas bibliográficas realizadas a respeito do tema e por meio da entrevista com o gestor da instituição e, posteriormente, com pessoas da comunidade local.

Quanto às contribuições proporcionadas por essa pesquisa, entende-se que o tema Responsabilidade Socioambiental está em crescente evolução, desse modo, qualquer empresa que almeje a continuidade e a lucratividade do seu negócio, pode fazer uso dessa pesquisa para entender quais contribuições o investimento em projetos socioambientais podem trazer para as empresas. Além disso, por meio deste estudo, torna-se possível para a sociedade entender as contribuições que a responsabilidade socioambiental, quando de fato implantada pelas empresas podem trazer para a comunidade.

Sendo o tema Responsabilidade Socioambiental relativamente recente quando tratado pelas pequenas e médias empresas, sugere-se o aprofundamento e sequenciamento do estudo, como forma de manutenção e evolução das práticas sustentáveis na indústria pesquisada, bem como a proposta de desenvolvimento dos projetos sociais e ambientais sugeridos pela sociedade local. 


\section{REFERÊNCIAS}

Aligleri, L, Aligleri, LA \& Kruglianskas, I. (2009). Gestão Socioambiental: responsabilidade e sustentabilidade do negócio. São Paulo: Atlas.

Barbetta, PA. (2011). Estatística aplicada às ciências sociais. Florianópolis: UFSC.

Borger, FG. (2013). Responsabilidade social empresarial e sustentabilidade para a gestão empresarial. Acesso em 15 de março, em: https://www.ethos.org.br/cedoc/responsabilidade- social-empresarial-e-sustentabilidadepara-a-gestao-empresarial/\#.xi5rdyhkjiu.

Botelho, KT. (2015). Indicadores de sustentabilidade empresarial: um estudo exploratório. Revista Eletrônica Interdisciplinar, 8 (2), 104-16.

Dias, R. (2017). Gestão Ambiental: Responsabilidade Social e Sustentabilidade. 3ed. São Paulo: Atlas.

Donaire, D. (2016). Gestão Ambiental na Empresa. 2ed. São Paulo: Atlas. GIL, AC. (2002). Como elaborar projetos de pesquisas. São Paulo: Atlas.

Global Reporting Initiative. (2015). Elaboração de relatórios de sustentabilidade, 2015. https://www.globalreporting.org/resourcelibrary/GRIG4-Part1-Reporting-Principles-and- StandardDisclosures.pdf.

Godoy, M, Pfitscher, ED, Gasparetto, V \& Limongi, B. (2007). Balanço Social: convergências e divergências entre os modelos do IBASE, GRI e Instituto ETHOS. In: Trabalho apresentando no I Congresso UFSC de Controladoria e Finanças, Florianópolis, SC, Brasil, 1, 25-9.

GRACE. (2014). Guia Responsabilidade Social nas Pequenas e Médias Empresas. http://www.grace.pt/ conteudos/00/04/00/00/GUIA-RS-NAS-PME_SITE_9985.pdf.

Hourneaux, FJr, Corrêa, HL \& Gomes, CM. (2010). Indicadores de sustentabilidade: em busca de um modelo de integração e de diferenciação estratégica para a gestão empresarial. Trabalho apresentado no XXXIV Encontro da Anpad, Rio de Janeiro, RJ, Brasil, 34,1-15.

Lacerda, AS \& Moura, D. (2016). A Responsabilidade Socioambiental Como Estratégia de Competitividade para as Organizações de Contemporaneidade. Trabalho apresentado no XII Congresso de Nacional Excelência em Gestão, Rio de Janeiro, RJ, Brasil, 12,1-16.

Lakatos, EM \& Marconi, MA. (1991). Fundamentos da Metodologia Científica. 3.ed. rev. e ampl. São Paulo: Atlas.

Martins, MF \& Candido, GA. (2008). Indicadores de Desenvolvimento Sustentável para Localidades: uma proposta metodológica de construção e análise. In: Candido, G.A. Desenvolvimento Sustentável e Sistemas de Indicadores de Sustentabilidade: formas de aplicação em contextos geográficos diversos e contingências especificas. Campina Grande - UFCG.

Pereira, AS, Shitsuka, DM, Parreira, FJ \& Shitsuka, R. (2018). Metodologia da pesquisa científica. [e-book]. Santa Maria. Ed. UAB/NTE/UFSM. Acesso em: 15 maio 2020.

Disponível em: https://repositorio.ufsm.br/bitstream/handle/1/15824/Lic_Computacao_MetodologiaPesquisa-Cientifica.pdf?sequence=1. 
Rabelo, NS \& Silva, CE. (2011). Modelos de indicadores de responsabilidade socioambiental corporativa. Revista Brasileira de Administração Científica, 2 (1),5-30.

Reis, CN \& Medeiros, LE. (2007). Responsabilidade social das empresas e balanço social. São Paulo: Atlas.

Tachizawa, T. (2002). Gestão Ambiental e Responsabilidade Social Corporativa: estratégias de Negócios Focadas na Realidade Brasileira. São Paulo: Atlas.

Tachizawa, T. (2004). Gestão Ambiental e Responsabilidade Social Corporativa: Estratégias de Negócios Focadas na Realidade Brasileira. 2.ed. rev. e ampl. São Paulo: Atlas.

Tachizawa, T. (2007) Organizações Não Governamentais e Terceiro Setor: Criação de Ongs e Estratégias de Atuação. 3.ed. São Paulo: Atlas. 
O NÍVEL DE MOTIVAÇÃO/SATISFAÇÃO E A RESPECTIVA INFLUÊNCIA NA QUALIDADE DO TRABALHO DOCENTE A PARTIR DA ANÁLISE LINGUÍSTICO-DISCURSIVA DA CONSTRUÇÃO DO ETHOS: UM ESTUDO DE CASO EM UMA UNIVERSIDADE FEDERAL BRASILEIRA

\author{
Geúno Bruno Vieira Soares \\ Universidade Federal de Itajubá \\ geunobruno@gmail.com \\ Priscilla Chantal Duarte Silva \\ Universidade Federal de Itajubá \\ priscillachantal@unifei.edu.br \\ Ricardo Luiz Perez Teixeira \\ Universidade Federal de Itajubá \\ ricardo.luiz@unifei.edu.br
}

\begin{abstract}
RESUMO
Um dos maiores desafios enfrentados pelas organizações em geral é a execução de uma gestão eficiente que consiga gerar resultados positivos para todos os stakeholders presentes. Entre estes, tem-se os colaboradores que são os principais agentes do processo de produção e que executam todas as atividades determinadas para se atingir os objetivos pré-estabelecidos. Dentro de uma universidade federal pública, ao oferecer uma graduação para jovens e adultos, essa incumbência é aumentada visto que a qualidade do serviço terá impacto direto no futuro do discente em questão. Assim, o objetivo deste estudo é determinar o nível de motivação e satisfação, a respectiva influência na qualidade do trabalho dos docentes em suas atividades laborais de ensino em uma universidade federal brasileira e analisar a
\end{abstract}

construção do ethos desses sujeitos a partir de uma análise linguístico-discursiva. Afinal, realizar trabalhos que gerem a construção do ethos dos docentes, por meio da análise dos seus discursos, e que possibilitem a verificação do nível de motivação e satisfação quanto ao empreendimento e a consequente relação com a qualidade do serviço executado é essencial para que haja um aprimoramento das atividades laborais e que o dever da instituição seja executado da melhor forma possível. Para isso, a metodologia adotada será o levantamento tipo survey, juntamente com a análise do discurso para se depreender o funcionamento, as necessidades e a construção do ethos do docente.

\title{
Palavras-chave:
}

Análise do discurso. Docência. Ethos. Motivação. Satisfação.

\begin{abstract}
One of the biggest challenges faced by organizations, in general, is the implementation of efficient management that can generate positive results for all stakeholders present. Among these, there are employees who are the main agents of the production process and who perform all the activities determined to achieve the pre-established objectives. Within a public federal university, when offering a degree to young people and adults, this task is increased since the quality of service will have a direct impact on the future of the student in question. Thus, the objective of this study is to determine the level of motivation and satisfaction, the respective influence on the quality of the work of teachers in their teaching work activities at a Brazilian federal university and to analyze the construction of the ethos of these subjects from $a$
\end{abstract}

linguistic analysis- discursive. After all, carrying out works that manage the construction of the teachers' ethos, through the analysis of their speeches, and that allow the verification of the level of motivation and satisfaction regarding the enterprise and the consequent relationship with the quality of the service performed is essential for there to be an improvement in work activities and that the institution's duty is carried out in the best possible way. For this, the methodology adopted will be the survey type survey, together with the analysis of the discourse to understand the functioning, the needs and the construction of the teacher's ethos.

\section{Keywords:}

Discourse analysis. Teaching. Ethos. Motivation. Satisfaction. 


\section{INTRODUÇÃO}

Uma das palavras que norteiam a sociedade como um todo é o termo "gestão" em razão de sua grande abrangência nos diversos aspectos que incluem a execução de um projeto. É comumente reconhecido e aplicado em processos organizacionais como um ato de gerenciar e administrar. Portanto, trata-se da tentativa de se alcançar os objetivos previamente estabelecidos pela empresa de forma que todos os recursos utilizados nesse processo sejam maximizados; sendo que no que tange à gestão de pessoas, inclui também a valorização dos colaboradores envolvidos. Afinal, a vida organizacional não se centra apenas nas atividades técnicas e/ou científicas, mas também na relação humana, uma vez que são as pessoas que vão mover o trabalho. Sendo assim, depreender a motivação humana já é hoje uma preocupação e compreende como uma das principais competências da gestão.

Nos moldes de Chiavenato (2010a, p. 476), "o conhecimento da motivação humana é indispensável para que o administrador possa realmente contar com a colaboração irrestrita das pessoas", pois acredita-se que o nível de motivação e satisfação é diretamente proporcional ao comprometimento, produtividade e qualidade do trabalho. Tal como aponta Chiavenato (2010a, p. 477), "quando uma pessoa está motivada, ela tenta trabalhar mais arduamente". Nesse sentido, quanto mais motivado estiver o colaborador, maior será a sua capacidade produtiva. É sob essa perspectiva e hipótese que este estudo se propõe a investigar.

Sabe-se que os setores público e privado possuem diferenças quanto à forma de gestão, em princípio. Na gestão de pessoas, há também diferenças, sobretudo no que concerne ao gerenciamento de competências e na meritocracia. Nesse sentido, vale investigar como o impulso motivacional é trabalhado no setor público, em que, normalmente, há hierarquias e estruturas de gestão mais engessadas. Sob esse aspecto, como "a motivação é um contínuo processo de satisfação de necessidades individuais" (CHIAVENATO, 2010b, p. 477), é preciso compreender como isso se dá no setor público e como o profissional docente canaliza seus esforços em prol da qualidade do ensino público brasileiro já que no setor privado, há uma certa competitividade própria.

A prestação de serviço em ambos os setores deve sempre buscar a melhoria contínua. Para que isso aconteça, os principais fatores trabalhados são a motivação e a satisfação dos colaboradores no que concerne às tarefas realizadas. Afinal, como garantem Schermerhorn, Hust e Osborn (1999, p. 133), "os grupos [de trabalho] podem ter um impacto substancial sobre as atitudes e os comportamentos dos seus membros [...]", sendo que "[...] sob as condições certas, os grupos podem melhorar o desempenho da tarefa e a satisfação no emprego dos seus membros".

Dado que essa função, na maioria das vezes, não é fácil, há uma grande demanda de energia para manter os funcionários confiantes e estimulados durante as atividades que realizam. Como é um resultado da interação entre o indivíduo e a situação envolvida e cada pessoa é única e tem os seus sentimentos variados ao longo do tempo, o nível de motivação e satisfação difere de ocasião para ocasião e momento para momento, não sendo, então, um registro constante e sólido.

Nos inúmeros estudos sobre esse assunto, há uma abordagem multidisciplinar que engloba, principalmente, as áreas da psicologia e da comunicação que recebem e/ou geram análises dos perfis 
humanos. Dessa forma, "a teoria administrativa se abastece deles [ou gera para eles] para criar condições de aplicabilidade dos seus conceitos na vida organizacional” (CHIAVENATO, 2010a, p. 476).

Diante de todo o exposto, tem - se o auxílio de obras como a de Juran (2015) que aborda a importância de se realizar estudos como objetivo de maximização da qualidade em um serviço, de Herzberg, Mausner \& Snyderman (1959) que apresentam, principalmente, hipóteses em relação à natureza da motivação de trabalho e seus efeitos dentro da organização e de Amossy (2005) que discorre sobre como é possível representar uma pessoa por meio do estilo, competências linguísticas e crenças para, enfim, analisar a sua personalidade por meio do seu discurso. Assim, busca - se responder a seguinte questão: qual o nível de motivação e satisfação dos docentes e a sua respectiva influência na qualidade do trabalho na atividade laboral executada em uma universidade federal brasileira?

Com o intuito de solucionar essa problemática, serão aplicados questionários e entrevistas aos profissionais, de forma anônima, respeitando as condições éticas de pesquisa, de modo que as respostas obtidas serão analisadas de acordo com obras literárias relacionadas ao assunto. Assim, posteriormente, ao obter um diagnóstico de possíveis problemas, torna - se viável propor tentativas de melhoria, no caso de ocorrências passíveis de mudança, e atingir, assim, uma elevação na prestação do serviço pedagógico aos discentes das graduações em observação.

Dessa maneira, entendendo que a principal função das universidades, tanto federais quanto privadas, é, justamente, realizar a formação de jovens e adultos de excelente forma, o ensino, ao lado da pesquisa e da extensão, é um dos principais fatores contribuintes para isto. E evidenciar os motivos que desmotivam e/ou geram insatisfação nos docentes faz com que seja possível eliminá-los e, consequentemente, contribuir diretamente para que a instituição cumpra seu papel com êxito. O objetivo deste estudo é determinar o nível de motivação e satisfação, a respectiva influência na qualidade do trabalho dos docentes em suas atividades laborais de ensino em uma universidade federal brasileira e analisar a construção do ethos desses sujeitos a partir de uma análise linguístico-discursiva.

\section{A Gestão de Pessoas no serviço público federal brasileiro: estrutura, organização e política}

Com uma evolução constante, os produtos e serviços organizacionais devem realizar aprimoramentos frequentes para manter o alto nível de qualidade em seus produtos. Como afirma Moretto Neto (2018), torna-se, portanto, uma incumbência da administração das instituições - independente do setor: comercial, social ou educacional - prezar por uma máxima qualidade nos resultados das suas produções por meio de um planejamento eficiente e ajustado com os stakeholders. Para garantir isso, um dos norteadores são os objetivos de desempenho. Os principais são: confiabilidade, custo, flexibilidade, qualidade e velocidade (SLACK, 2018).

Como é afirmado por Slack (2018), de maneira geral, à medida que o nível de satisfação destes indicadores aumenta, cresce, também, o reconhecimento de que as atividades executadas são satisfatórias. Tal fato pode gerar, então, satisfação nos colaboradores do trabalho e aumentar a motivação e engajamento desses com as tarefas feitas. Para que isso possa ser feito com eficiência, é necessário que a organização possua uma gestão eficiente. Vista como um instrumento tecnológico neutro e racional, segundo Junquilho (2001), a gestão promove o alcance de resultados coletivos esperados, sendo uma atividade complexa e formada por estruturas formalizadas de sistemas de controle. 
Lima et al. (2018) destaca que a gestão possui quatro subfunções principais. São elas: planejar, ou seja, determinar com antecedência quais tarefas devem ser realizadas e como executá-las; organizar, isto é, estabelecer as relações formais entre as pessoas e a interface destas com as tecnologias e os recursos existentes; influenciar de maneira positiva no comportamento dos colaboradores, para que eles realizem as suas obrigações, por meio de uma liderança eficaz, com comunicação positiva e, ainda, motivação constante; $\mathrm{e}$, finalmente, controlar os resultados da organização por meio de comparações entre os resultados atingidos e os esperados (INSTITUTO SUPERIOR DE CONTABILIDADE E ADMINISTRAÇÃO DO PORTO, 2014).

Para que todos esses aspectos possam ser abordados com êxito, a gestão se subdivide em diferentes âmbitos, sendo um deles a Gestão de Pessoas (GP). Antigamente denominada Recursos Humanos, esta é fundamental nas instituições, pois, como defende Magalhães Filho e Pereira (2013), os relacionamentos entre os indivíduos se cruzam com os desejos e anseios pessoais e profissionais de cada um, visto que há em todos o objetivo de crescimento e desenvolvimento dentro da instituição, o que pode, por consequência, causar danos se não for bem administrado pelos responsáveis.

Entretanto, esse conceito da coordenação de pessoas só foi agregado com o passar do tempo. Como afirma Ribas e Salim (2013), inicialmente, no período entre 1900 e 1950, a GP possuía apenas a administração das questões burocráticas, tais como: folhas de pagamento; registros e controle de horários, além de ter enfoque no operacional e considerar os colaboradores como simples recursos de produção, isto é, homem-máquina. De 1950 a 1990, houve um avanço em relação ao elemento humano e a sua inserção nos processos de produção com o desenvolvimento de novas atividades táticas, subsistemas e de uma visão diferenciada em relação ao capital humano. Já a partir de 1990, a Gestão de Pessoas tem procurado se desenvolver ainda mais em relação à importância das pessoas como fornecedoras de conhecimento e componentes fundamentais para o processo.

Dessa forma, para que haja contribuição para a eficácia organizacional, Chiavenato (2010b) determina que alguns meios são utilizados, como: auxílio para a organização alcançar os objetivos e realizar a sua missão; geração de competitividade; promoção de treinamentos, motivação e satisfação aos funcionários; manutenção constante da qualidade de vida no trabalho, entre outros. Todos esses aspectos estão alocados dentro dos seis processos da GP mostrados na Figura 1 abaixo.

Figura 1 - Os processos da Gestão de Pessoas

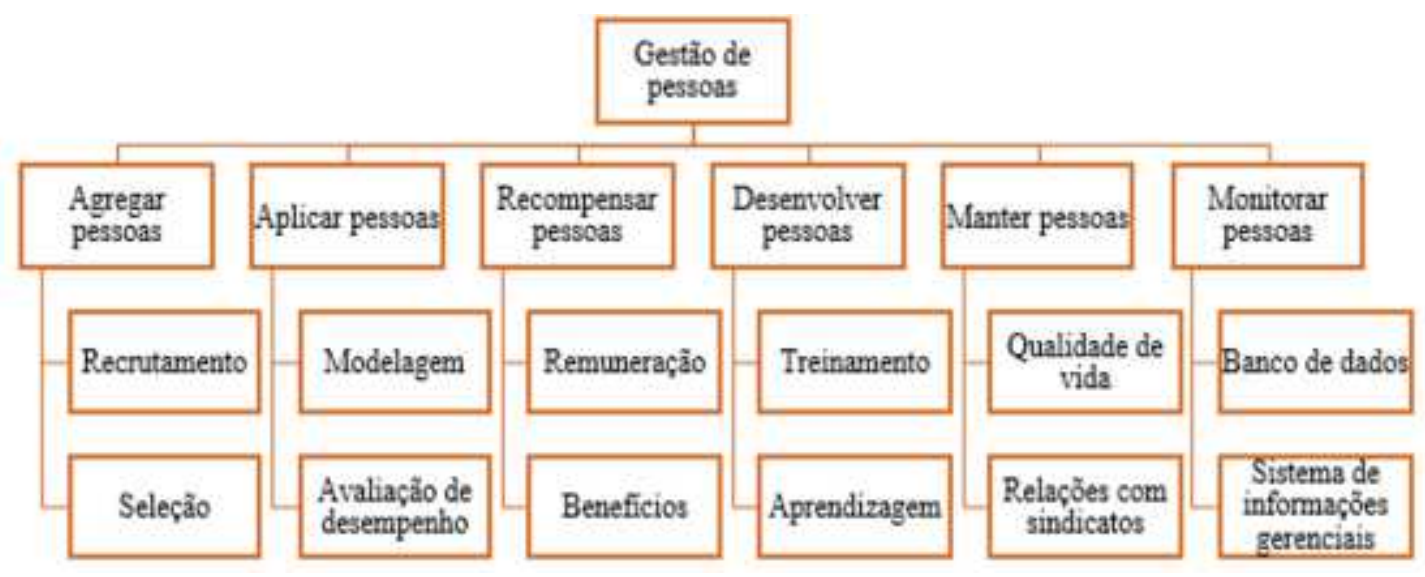

Fonte: Adaptado de Marques (2015) 
Assim, tem-se que:

- Agregar pessoas: recrutar e incluir os novos colaboradores na empresa por meio de processos seletivos;

- Aplicar pessoas: designar os novos funcionários para as respectivas atividades, com as devidas orientações e acompanhamentos;

- Recompensar pessoas: incentivar os contratados, além de satisfazer algumas das suas necessidades pessoais e profissionais, utilizando remunerações, benefícios e serviços sociais;

- Desenvolver pessoas: capacitar e incrementar o desenvolvimento pessoal e/ou profissional de cada um por meio de treinamentos, programas e gestão do conhecimento;

- Manter pessoas: criar ambientes favoráveis para o trabalho, tanto em relação aos fatores físicos quanto aos psicológicos, prezando por princípios como clima e segurança;

- Monitorar pessoas: acompanhar e controlar as atividades executadas com as constantes verificações dos resultados obtidos.

Nesse ciclo, há uma inter-relação que faz com que a boa ou a má utilização de um dos processos gere, respectivamente, resultados bons ou ruins para o outro devido a interdependência existente. Por consequência, a organização tem como obrigação manter um equilíbrio entre todas as atividades por meio de ferramentas e técnicas para conseguir, então, executar uma boa gestão de pessoas. $E$, quando isso ocorre, o colaborador tende a se sentir mais motivado, graças a todo o amparo recebido pela alta direção, e gerar, portanto, melhores resultados para a empresa.

\subsection{Motivação nas Organizações}

Um dos principais objetivos buscados hoje em dia pelas organizações é gerar motivação em seus colaboradores nas atividades do cotidiano. Como garante Pedroso et al. (2018), esse termo significa o "[...] conjunto de forças internas que mobiliza o indivíduo para atingir um dado objetivo como resposta a um estado de necessidade, carência ou desequilíbrio". Ou seja, indica o processo em que o comportamento humano é incentivado por algum motivo ou razão em específico.

A psicologia considera a motivação como uma força interna, presente nos sentimentos de cada pessoa, visto que os indivíduos possuem diferentes necessidades e anseios, tornando as pessoas diferentes entre si. Bergamini (2008) garante que:

A motivação, pode e deve ser considerada como uma força propulsora que tem suas fontes frequentemente escondidas dentro de cada um, e que a satisfação ou insatisfação que podem oferecer fazem parte integrante de sentimentos de prazer ou desprazer diretamente acessíveis somente a quem experimenta (BERGANINI, 2008, p. 108).

Alcançar, então, o pleno estado de motivação dos funcionários é uma tarefa difícil, pois, como mencionado, inclui fatores individuais e de personalidade, além do ambiente organizacional. Uma das incumbências da Gestão de Pessoas é, portanto, conhecer o perfil do colaborador e as situações vivenciadas por ele, sem aplicar pressupostos tradicionais que, frequentemente, são falhos. 
Uma das técnicas mais aplicadas para engajar o trabalhador em sua operação é aplicar o estilo participativo na instituição. Desse modo, por meio de uma gestão à vista, há a possibilidade de o empregado colaborar e participar ativamente dentro da empresa, tendo ciência sobre os seus frutos e resultados e, assim, a produtividade e satisfação consigo tende a aumentar, o que proporcionará melhores resultados de forma geral.

Apesar de funcionar de modo regular, essa estratégia isoladamente pode não ser suficiente para instigar os funcionários. Tal fato se dá porque, como citado anteriormente e também abordado por Chiavenato (2010b), há uma variação nas condições que motivam os funcionários de uma organização. Com o intuito de descobrir tais fatores, então, há diversas teorias e estudos que relacionam os principais fatores.

Uma das utilizadas pelos gestores, principalmente em universidades federais, tema-foco do presente trabalho, é a Pirâmide de Maslow, desenvolvida por um psicólogo americano, que afirma que o fator motivacional está distribuído em níveis hierárquicos representados na forma da Figura 2. A medida que o nível de necessidades é atingido, da base para o topo, os elementos deixam de ser motivadores e o usuário passa a almejar, então, o nível seguinte.

Figura 2 - Pirâmide de Maslow

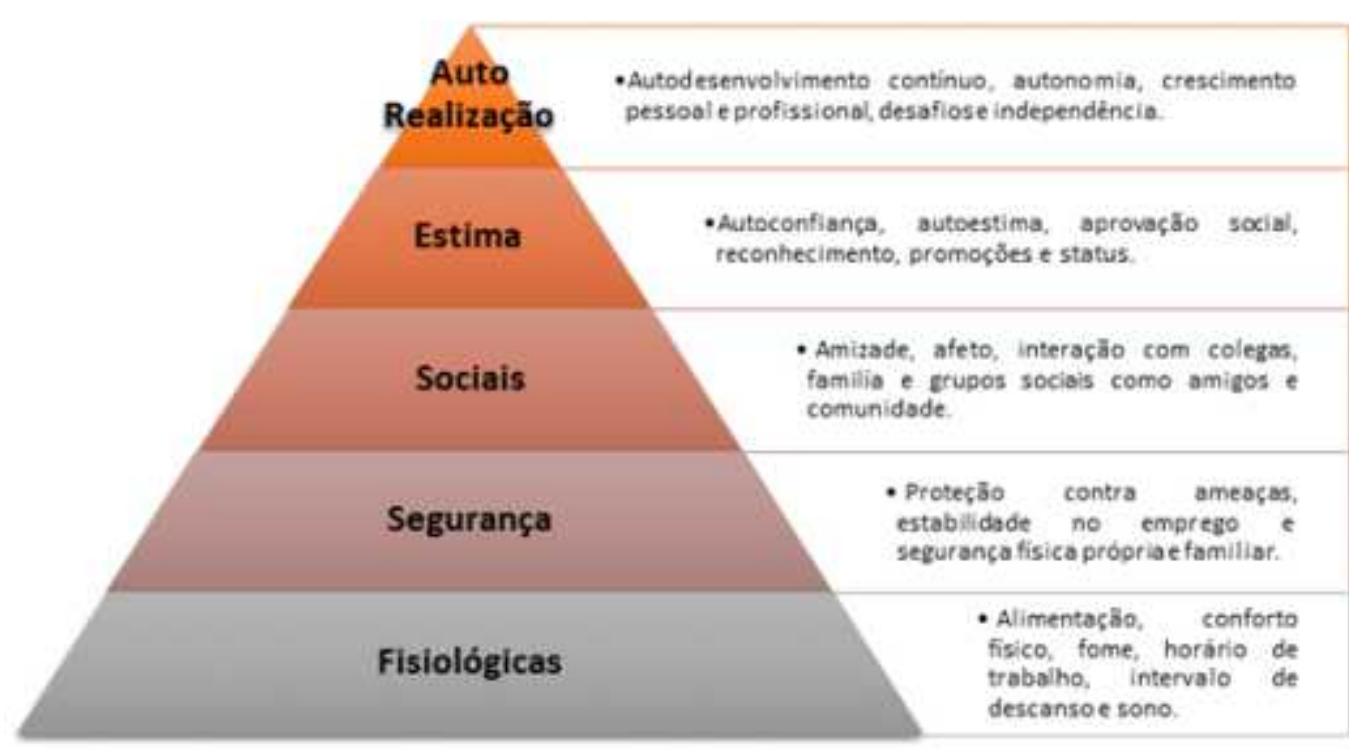

Fonte: Adaptado de Sá e Sacheti (2015)

Outra teoria amplamente difundida é a Teoria dos Dois Fatores, formulada por Frederick Herzberg, que consiste na divisão dos fatores motivacionais em duas categorias: higiênicos, benefícios como ambiente de trabalho, segurança e salário que garantem o mínimo de satisfação, e motivadores, "[...] relacionados com o cargo ocupado pelo empregado e abrange reconhecimento e oportunidade de progresso profissional [...]" que geram diferentes níveis de satisfação (CHIAVENATO, 2010b).

Ainda, vale citar também a Teoria Xe Y, criada por Douglas Mc Gregor na década de 1960 segundo Santos et al. (2010), em que há uma distinção entre dois perfis de personalidades. O estático, sem motivação e tradicional, denominado de Teoria X, e, de forma oposta, o colaborador participativo, ambicioso e proativo é o que tem potencial de crescer e se desenvolver, chamado de Teoria Y (JOFRE; SANTOS, 2015). 
De acordo com o comportamento nas organizações, portanto, os profissionais são divididos nas duas categorias, permitindo aos superiores a escolha do modo de trabalho perante a eles.

Outras técnicas de engajamento e motivação também são utilizadas, pois, como destaca Chiavenato (2010a), a qualidade de vida influencia amplamente na motivação para o trabalho do colaborador. Isso ocorre por causa do envolvimento de aspectos intrínsecos e extrínsecos nas atitudes e comportamentos, tornando-se relevante para a produtividade da empresa como um todo.

\subsection{A carreira docente no serviço público federal brasileiro}

Iniciar uma carreira em uma profissão requer adaptação, preparação e tempo. Tal fato não é diferente para os professores e docentes que começam a lecionar e se tornam membros de uma instituição e das diversas atividades ali presentes. Em alguns casos, juntamente com o novo emprego e as descobertas recorrentes, ocorrem também mudanças drásticas no estilo de vida do profissional, já que podem haver alterações geográficas e/ou familiares nesse mesmo tempo.

Por isso, então, há a possibilidade de acontecer grandes perturbações e choques emocionais logo nesse início, já que há um "[...] impacto por eles sofrido quando iniciam a profissão e que poderá perdurar por um período de tempo mais ou menos longo" (SILVA, 1997). Este mesmo autor destaca ainda que quando essa quebra da expectativa ocorre, alguns problemas como mudança de atitude, de comportamento e de personalidade ou, até mesmo, abandono da profissão em casos extremos podem acontecer e gerar graves danos por toda a vida do profissional. Torna-se necessário, portanto, um estudo acerca da motivação e satisfação desses profissionais desde o início da carreira.

Após essa fase principiante que dura em média três anos, no serviço público, segundo Huberman (1995), tem - se um período de outros três em que há uma consolidação da docência gerada pela estabilidade do profissional. E, ainda segundo o mesmo autor, a partir do sétimo ano de trabalho nesta área, ocorre o período de diversificação do trabalho em que o profissional passa a experimentar outras ações e dinamizar o seu papel dentro e fora da faculdade. Posteriormente, por volta do vigésimo quinto ano de lecionamento, há um distanciamento afetivo da profissão, sendo que, após mais dez anos, ele, provavelmente, já estará iniciando o seu afastamento por completo do seu trabalho e de toda a rotina imposta, completando, então, o ciclo de vida do profissional docente.

Entretanto, como garante Cardoso (2017), não há uma linearidade entre essas etapas e elas não são estáticas. Em outros termos, as características de uma fase podem estar presentes em outra graças à singularidade de cada pessoa e de todas as influências e particularidades do local de trabalho, o que valida, por consequência, o estudo sobre a motivação e a respectiva influência desta no modo de vida do indivíduo.

Nas universidades, principalmente federais, há alguns requisitos para que o docente possa ser considerado pela sociedade em geral como um bom professor, como destacam Rios, Ghelli e Silveira (2019, p 144). Como a instituição de ensino superior é educativa, o profissional deve ser “[...] capaz de articular o currículo com a teoria, a ética, a competência, a habilidade de se relacionar com os alunos, com o mundo à sua volta e demonstrar também ser capaz para formar os seus membros como cidadãos (seres humanos e sociais) e profissionais competentes". Ele sintetiza isso, então, nas seguintes características: dinamismo, dominação do conteúdo e das técnicas de aprendizagem, engajamento e, por fim, compromissado com o aprendizado do aluno. 
Para verificar se o profissional possui esse perfil buscado pelas organizações e, a partir disso, gerar progressões na carreira do mesmo, é aplicado periodicamente um sistema de avaliação de desempenho (AD). Essa metodologia dinâmica consiste no julgamento das qualidades, dos pontos de melhoria e o valor da contribuição do docente para a instituição pertencente. Por meio da sua aplicação e do consequente feedback, é possível, então, eliminar as deficiências de desempenho e manter ativa a busca por uma melhoria contínua em relação ao serviço prestado (SAKANO et al, 2014).

A aplicação e a execução da avaliação podem ser realizadas de diferentes formas. Como afirma Marra e Tose (2012), pode se ter foco na aferição do potencial para posições que demandam assuntos complexos, no desenvolvimento profissional para aprimorar talentos, na análise comportamental para identificar os comportamentos no ambiente de trabalho ou, ainda, na realização de metas e resultados para medir os esforços em busca dos objetivos previamente estabelecidos. Tais abordagens podem ser avaliadas pelos gestores, equipes de trabalho, alunos e, até mesmo, por si próprio.

Entre os métodos de se realizar a AD, segundo Chiavenato (2010a), os mais tradicionais são:

- escalas gráficas: baseado em uma tabela constituinte por fatores de avaliação como pontualidade, personalidade e atendimento a prazos, versus os respectivos graus delegados, variando entre níveis de fraco a ótimo;

- escolha forçada: consiste em uma avaliação por meio de blocos de frases descritivas, sendo que o executor do teste deve selecionar apenas uma ou duas por conjunto que focalizam determinados aspectos do comportamento dentro da empresa;

- pesquisa de campo: é composto por entrevistas entre o especialista e os funcionários em avaliação, sendo que as perguntas são personalizadas para cada funcionário em análise;

- método dos incidentes críticos: composto pelas características extremas que representam os desempenhos de sucesso ou de fracasso, sem se preocupar com o cotidiano;

- lista de verificação: assentado em uma relação de fatores a serem considerados referentes a cada funcionário, os quais recebem uma avaliação quantitativa, se tornando, então, uma simplificação do método das escalas gráficas.

A principal vantagem e desvantagem de cada um destes está demonstrado no Quadro 1 abaixo. Apesar de poder ser executada de diversos modos, a avaliação deve sempre transmitir um feedback aos colaboradores sobre o desempenho dos mesmos, independentemente do resultado, para que os objetivos gerais sejam alcançados e o julgamento que preza pelos critérios de equidade e justiça, ao passo que estimule as pessoas, seja realizado (MARRA, TOSE; 2012).

No setor público, especificamente no ensino superior, essa ferramenta é dividida em duas vertentes, executada de acordo com os cargos em análise: docentes ou técnicos-administrativos. Segundo Brasil (2005), neste último, o plano de carreira é dividido em cinco níveis de classificação, representados pelas letras $A, B, C, D$ e $E$, sendo que cada um possui quatro classes de capacitação, simbolizados por algarismos entre I a IV, e dezesseis diferentes padrões de vencimento básico. A ascensão, que pode acontecer por capacitação ou por mérito profissional, pode ocorrer somente dentro do mesmo nível e, para trocar de A para B, por exemplo, o servidor deve ingressar novamente na instituição.

Já na docência, as classificações são realizadas da seguinte forma: classes A, B, C, D e E, com diferentes níveis de vencimento em cada um. A categoria $A$ é composta por professores ingressantes, dividindo se entre graduados, chamados de auxiliares, mestres, denominados por assistentes, e doutores, que possuem adjunto como nominação. 
Quadro 1 - Comparação entre os métodos da avaliação de desempenho

\begin{tabular}{|c|c|c|}
\hline Modelo & Vantagens & Desvantagens \\
\hline $\begin{array}{c}\text { Escalas } \\
\text { gráficas }\end{array}$ & $\begin{array}{c}\text { Permite fácil entendimento } \\
\text { aos avaliadores. }\end{array}$ & $\begin{array}{c}\text { O avaliador deve se ajustar ao } \\
\text { instrumento, e não as características do } \\
\text { avaliado, possuindo, então, pouca } \\
\text { flexibilidade. }\end{array}$ \\
\hline $\begin{array}{c}\text { Escolha } \\
\text { forçada }\end{array}$ & $\begin{array}{c}\text { Gera resultados com grau de } \\
\text { confiança maior e é isento de } \\
\text { influências subjetivas. }\end{array}$ & $\begin{array}{c}\text { Não gera uma estrutura que permite } \\
\text { tomada de decisões }\end{array}$ \\
\hline $\begin{array}{c}\text { Pesquisa de } \\
\text { campo }\end{array}$ & $\begin{array}{c}\text { Permite a realização de um } \\
\text { planejamento de ação que seja capaz } \\
\text { de remover os obstáculos } \\
\text { encontrados. }\end{array}$ & $\begin{array}{c}\text { Como demanda temponó um um } \\
\text { instrumento mais demorado que os } \\
\text { demais. }\end{array}$ \\
\hline $\begin{array}{c}\text { Incidentes } \\
\text { críticos }\end{array}$ & $\begin{array}{c}\text { Possui uma descrição fácil e que faz } \\
\text { com que as decisões possam ser } \\
\text { tomadas mais rápido. }\end{array}$ & $\begin{array}{c}\text { Pode colocar um determinado } \\
\text { colaborador em um grau diferente da } \\
\text { realidade encontrada. }\end{array}$ \\
\hline $\begin{array}{c}\text { Lista de } \\
\text { verificação }\end{array}$ & $\begin{array}{c}\text { Há a possibilidade do trabalhador } \\
\text { avaliar a si mesmo para que a } \\
\text { empresa possa contrapor com a } \\
\text { avaliação padrão e obter um } \\
\text { resultado mais elaborado ao } \\
\text { empregado. }\end{array}$ & $\begin{array}{c}\text { Um funcionário pode não ser capaz de } \\
\text { avaliar o seu próprio desempenho } \\
\text { objetivamente e, assim, tornar o } \\
\text { resultado da c omparação superficial. }\end{array}$ \\
\hline
\end{tabular}

Fonte: Adaptado de NETTO et al. (2016)

Brasil (2012) também afirma que o princípio básico para ocorrer o desenvolvimento na carreira é o cumprimento de "[...] interstício mínimo de 24 (vinte e quatro) meses no último nível de cada Classe antecedente àquela para a qual se dará a promoção". Dessa forma, a progressão mencionada pode ocorrer de um nível para o outro, dentro da mesma classe, por avaliação do desempenho acadêmico no período em questão ou de uma classe para outra por meio de titulação ou desempenho acadêmico especial.

Fidler (1989) apud Reifschneider (2018) observa que, ao ser aplicada essa ferramenta de avaliação dos profissionais, alguns desafios são encontrados. Entre eles, a independência dos profissionais em seus trabalhos, a presença de incertezas em relação a recompensas e uma possível subjetividade ao se avaliar o ensino devido a escolha dos critérios, dentre outros, o que pode ocasionar, por consequência, uma redução na qualidade do serviço oferecido em questão causado pela ausência de motivação no trabalho executado.

Além disso, é necessário verificar todas as vertentes por trás das respostas obtidas independentemente do método de aplicação da avaliação de desempenho. Para isso, utiliza-se técnicas, sendo a análise do discurso uma delas. 


\section{A Análise do discurso e a formação do ethos docente}

Para que se entenda essa técnica que possui Michel Pêcheux como um dos fundadores franceses, é necessário, primeiramente, definir o conceito de discurso, mesmo que este esteja presente no cotidiano das pessoas em debates e discussões e seja um conceito empiricamente entendido por grande parte da população. Segundo Fernandes (2008), o discurso não é a língua, nem o texto e nem a fala executada, mas, como precisa de elementos linguísticos para se ter uma existência material, implica-se como uma exterioridade à língua, encontrado no social e que envolve questões de natureza além da linguística.

Tomando como objeto da Análise do Discurso (AD), etimologicamente, "[...] a palavra discurso tem em si a ideia de curso, de percurso, de correr por, de movimento. O discurso é assim palavra em movimento, prática de linguagem [...]" (ORLANDI, 1999, p. 15). Quando é exercido por alguém, o locutor constrói uma imagem de si, isto é, uma representação figurativa do que deseja expressar, denominada ethos (AMOSSY, 2005). Para esta autora, "todo ato de tomar a palavra implica a construção de uma imagem de si. Sendo assim, por meio da identificação do estilo do autor, das escolhas lexicais, crenças e a própria construção do discurso, é possível perceber neste marcas de subjetividade e a imagem que este tem de si. O ethos por fim designa como o que o orador deve mostrar ao seu público. "O orador enuncia uma informação e ao mesmo tempo diz: sou isto, não sou aquilo" (AMOSSY, 2005, p.10). em geral, a noção de ethos está ligada à enunciação. Para cada tipo de discurso, o locutor assume certo papel social conforme suas escolhas e intencionalidade.

Este é definido por Roland Barthes como os traços de caráter que o orador deve exibir aos seus ouvintes enquanto se discorre sobre um determinado assunto para que cause boa impressão, independente da sinceridade (BARTHES, 1970 apud AMOSSY, 2005). Dessa maneira, o ethos é o jeito do indivíduo e, assim, quando se realiza a análise discursiva, há o objetivo de interrogar os sentidos estabelecidos pelas diversas formas de produção do discurso: verbal e não verbal (CAREGNATO e MUTTI, 2006).

A AD é definida então como "[...] uma disciplina de interpretação [...]", como garante ainda Caregnato e Mutti (2006), sendo diversa e com diversos enfoques durante sua aplicação. Apesar da finalidade distinta, todas as formas de execução possuem a mesma premissa de rejeitar a noção realista de que a linguagem é simplesmente um meio neutro para refletir ou descrever o mundo, além de destacar a importância central do discurso na construção da vida social do ser humano (BAUER; GASKELL, 2008).

Durante o emprego da Análise do Discurso, há o objetivo de unir, então, o interno, composto pela discursivização, e o externo, integrado pela relação entre o enunciado e a enunciação (GREGOLIN, 1995). Ainda segundo o mesmo autor, executá-la significa, portanto, a busca pelo entendimento e pela explicação entre a construção de sentido de um texto e a forma como este se articula com a história e com a sociedade que o produziu.

Diferentemente da Análise de Conteúdo $(A C)$, outra disciplina formulada de maneira similar à $A D$, o foco nesta é totalmente qualitativo. E, além disso, Caregnato e Mutti (2006) ressaltam ainda que a principal diferença se encontra na perspectiva: enquanto que a $A D$ trabalha com o sentido relacionado ao discurso, a AC utiliza a materialidade linguística, por meio das condições empíricas do texto, que permitirão uma categorização em fatores que possibilitam a sua interpretação.

Portanto, como conclui Gregolin (1995), a Análise do Discurso é um valioso instrumento de trabalho pois oferece meios para refletir sobre a estrutura e geração de sentido nos discursos realizados. Dessa forma, os docentes podem utilizar-se dessa metodologia para enriquecer as atividades feitas dentro 
das salas de aula, nos projetos e nas pesquisas executadas visto que amplia as modalidades textuais com o estudo de todas as nuances e aspectos envolvendo um discurso, gerando, então, a tendência de aprimoramento e de melhorias contínuas.

\section{Metodologia}

A estrutura do plano de amostragem adotado baseou-se no método de amostragem estratificada de docentes de uma universidade federal. Utilizou-se estratégia de estratificação definida a partir de questionário tipo survey, com vistas a atender aos domínios de análise pré-estabelecidos para o estudo.

Para que o objetivo de realizar uma pesquisa do tipo quanti-qualitativa com máxima qualidade pudesse ser alcançado com êxito, dividiu-se a realização desta em três momentos distintos e sucessórios. Assim, os conhecimentos foram adquiridos e agregados ao longo de cada etapa em busca do objetivo final.

Dessa maneira, primeiramente realizou-se uma revisão bibliográfica dos principais assuntos que permeiam esta pesquisa. Isso foi feito para que os passos seguintes pudessem ser baseados em autores e obras renomadas para que se garanta a credibilidade dos dados e a qualidade em todas as informações documentadas e apresentadas. Além disso, como afirma Echer (2011), tal ação promove diversos benefícios como "[...] apoiar decisões do estudo, instigar dúvidas, verificar a posição de autores sobre uma questão, atualizar conhecimentos, reorientar o enunciado de um problema, ou ainda, encontrar novas metodologias que enriqueçam o projeto de pesquisa".

Com a finalização desta etapa, em seguida, definiu-se o local de aplicação da pesquisa, uma universidade federal brasileira, e elaborou-se um questionário tipo survey - sendo este definido como uma "[...] obtenção de dados ou informações sobre características, ações ou opiniões de determinado grupo de pessoas [...]" (Freitas et al., 2000) - para ser aplicado aos docentes ali presentes. Assim, os autores elaboraram as questões mostradas no Apêndice $B$ deste relatório no qual é possível perceber uma divisão dos temas em duas áreas, pessoal e profissional, envolvendo o presente bem como o futuro do colaborador.

Em grande parte das perguntas, utilizou-se a Escala Likert para mensuração das respostas. Nela, afirmativas são apresentadas e o respondente declara o seu grau de concordância com a frase em questão. Dessa forma, cada uma das opções possui um valor correspondente numa escala numérica original para que, posteriormente, isso ajude na contabilização dos dados colhidos. McClelland (1976) destaca que para que o questionário seja bem preparado, ele deve possuir características como relevância para o respondente, ser breve e, também, ausência de ambiguidade.

Por fim, depois de colhidos os resultados, realizou-se, para a análise qualitativa, uma análise do discurso pelo ethos de todas as respostas obtidas na aplicação do questionário tipo survey, cujas conclusões serão apresentadas nos tópicos seguintes. Isso, como mencionado anteriormente, é feito com o intuito de verificar a imagem que o profissional tem de si e a própria representação perante suas palavras e falas.

Dessa forma, a presente pesquisa é um estudo de caso em uma universidade federal brasileira em que se há o intuito de verificar o nível de motivação e de satisfação dos colaboradores e, ainda, os principais fatores que influenciam, tanto positivo quanto negativamente, na variação dessa sensação em cada um dos profissionais. 


\section{Análise do discurso, Resultados e Discussões}

O trabalho de planejamento da amostra levou em consideração os resultados de estudos que enfocaram a aplicação do questionário supramencionado com os docentes da universidade federal em análise, pelo qual tornou-se possível obter algumas informações quanto à motivação e satisfação destes com o trabalho exercido. Primeiramente, é necessário destacar as principais características da amostra coletada.

Em relação à faixa etária dos entrevistados, como é exibido na Figura 3 a seguir, a maior parte da população possui idade até 40 anos (46,94\%), seguido de pessoas na faixa etária entre 40 e 50 (32,65\%) e, depois, acima de 50 anos (20,41\%). Já em relação ao sexo, 61,4\% das pessoas são homens e $38,6 \%$ são mulheres.

Figura 3 - Faixa etária da população

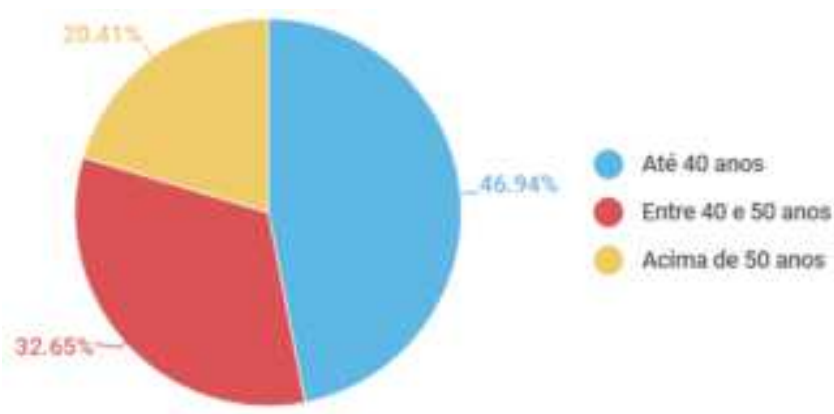

Fonte: Autores (2019)

Além disso, 67,75\% da amostra se declara solteiro, 28,38\% casado e 4,05\% divorciado. Quanto ao número de filhos, 39,47\% não possui nenhum, 28,95\% possui um, 19,47\% possuem dois filhos e $11,84 \%$ possuem três. Quanto à naturalidade, os entrevistados que optaram por responder essa questão são da maioria da região Sudeste $(90,16 \%)$, local residente da universidade. Entretanto, a entrevista possui também respondentes nascidos em outras localidades, como Centro-oeste, Sul, Norte e Distrito Federal, além de Peru e Colômbia.

No que tange ao grau de titulação dos entrevistados, $84,4 \%$ possui o Doutorado como grau de instrução; $34,69 \%$ possui mais de quinze anos de exercício na profissão docente (Figura 4); 38,14\% possui entre 7 e 11 anos de vínculo com a presente universidade (Figura 5); e 31,63\% possui esse mesmo tempo mencionado, entre 7 a 11 anos, de trabalho no serviço público como docente (Figura 6).

Figura 4 - Tempo de docência

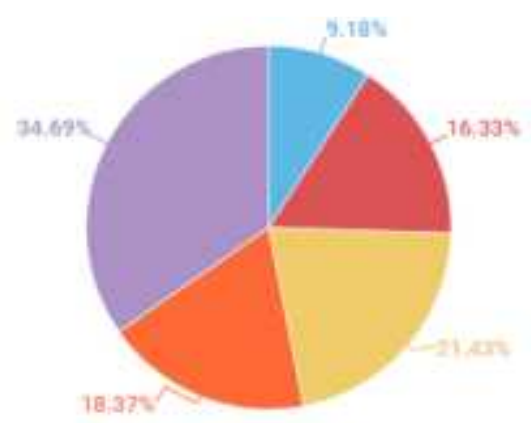

Figura 5 - Tempo na universidade em análise
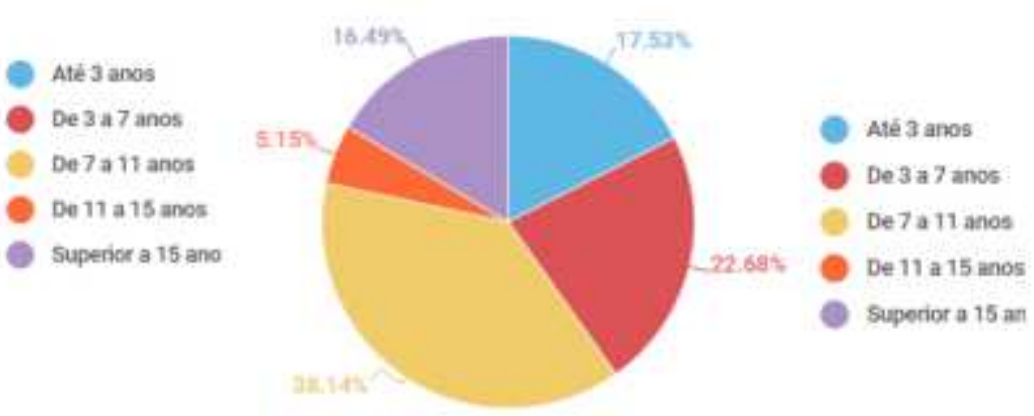

Fonte: Autores (2019) 
Figura 6 - Tempo como docente no serviço público

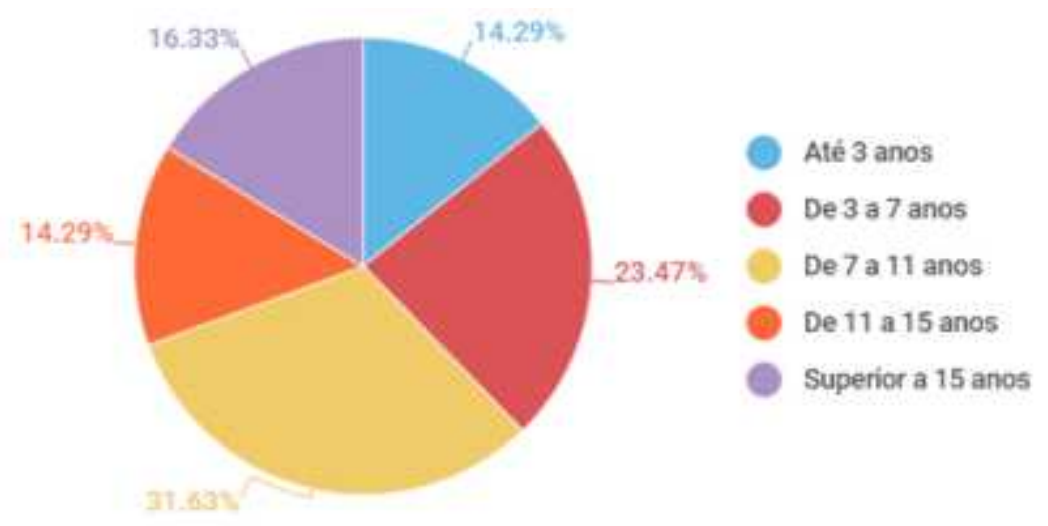

Fonte: Autores (2019)

Por fim, 86,7\% da população afirma exercer regime estável e não probatório, 97,6\% declara dedicação exclusiva e não parcial e $94 \%$ das pessoas não prestam serviços externos para outras fontes empregatícias.

Analisando, então, os dados obtidos, é possível concluir que a maior parte dos profissionais se declaram felizes e realizados com o cargo executado na faculdade. Isso se comprova pois $85,5 \%$ do total escolheu a carreira docência como opção de vida, e não obrigação, 96,4\% gosta de lecionar, $94,2 \%$ se sente realizado com todas as conquistas alcançadas até o momento e 90,6\% deseja crescer ainda mais em suas carreiras.

Isto posto, de maneira geral, todos declaram fatores específicos que geram maior motivação do que outros, sendo a ética e o respeito entre os colegas, alunos e instâncias superiores os mais mencionados. Além disso, o reconhecimento profissional, presente em um dos pilares da Pirâmide de Maslow mencionada no decorrer deste trabalho, também foi amplamente lembrado pelos entrevistados. Porém, como é visto na Figura 7, apenas $51,8 \%$ dos entrevistados se sentem reconhecidos dentro da instituição onde atuam. Nesse aspecto, a instituição deveria apoiar-se em mecanismos para valorizar e reconhecer o trabalho docente para que o nível de satisfação e motivação possa elevar-se.

Figura 7 - Reconhecimento da instituição

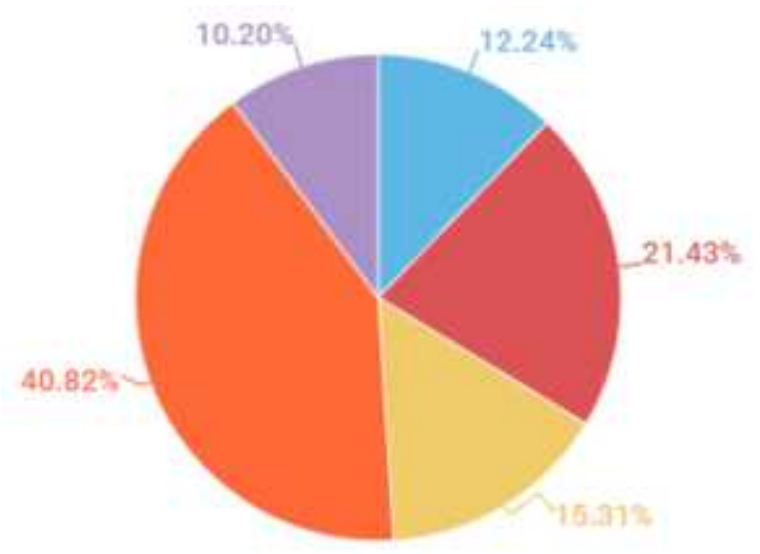

Discordo totalmente

Discordo parcialmente

Indiferente

Concordo parcialmente

Concordo totaimente

Fonte: Autores (2019) 
Esse reconhecimento está diretamente relacionado com a busca dos docentes para deixarem as aulas mais atrativas para os alunos, visto que $84,7 \%$ aplicam diferentes metodologias nas disciplinas nas quais lecionam, $96,4 \%$ se preocupa com o próprio desempenho e $97,6 \%$ dos profissionais priorizam o aprendizado dos discentes quanto ao conteúdo ofertado. Sob esse aspecto, pode-se considerar também a necessidade de ser reconhecido tanto pelo aluno, quanto pela instituição em termos administrativos ou mesmo de carreira. Nas questões dissertativas, grande parte dos informantes alegou falta de: valorização da carreira; incentivos e supervalorização do corpo discente em detrimento à valorização docente.

Já quando questionados sobre o crescimento profissional, aspecto abordado por eles como um dos principais fatores motivantes, $66,1 \%$ dos profissionais declararam que estão de acordo com os objetivos e metas que devem ser alcançados para progredirem na carreira, 51,8\% concordam com a forma de avaliação do trabalho e $67,01 \%$ das pessoas estão satisfeitas com as oportunidades geradas pelo trabalho. Esta última informação pode ser vista na Figura 8.

Figura 8 - Satisfação com as oportunidades geradas

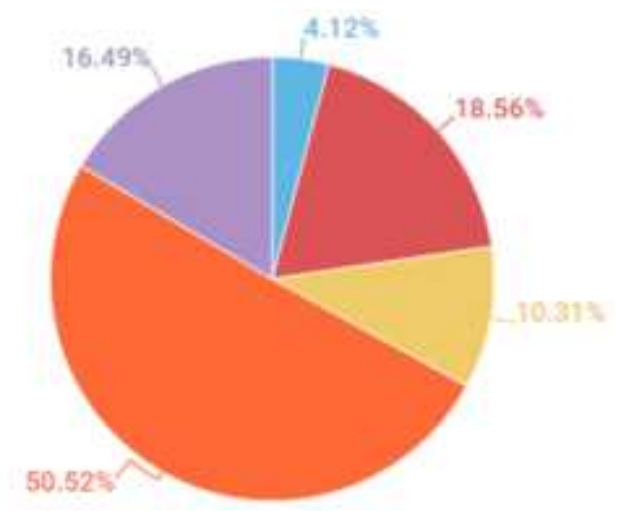

Discordo totalmente

Discordo parcialmente Indiferente

Concordo parcialmente

Concordo totalmente

Fonte: Autores (2019)

Estes aspectos estão relacionados de maneira direta com o clima organizacional da empresa atuante outro item mencionado como grande influenciador na motivação dos docentes para 81,2\% dos profissionais que participaram da pesquisa. Segundo a amostra coletada, $48,3 \%$ discordam ou são indiferentes quanto à afirmação de que o ambiente de trabalho favorece a execução das tarefas, como é visto na Figura 9.

Figura 9 - Favorecimento do ambiente de trabalho

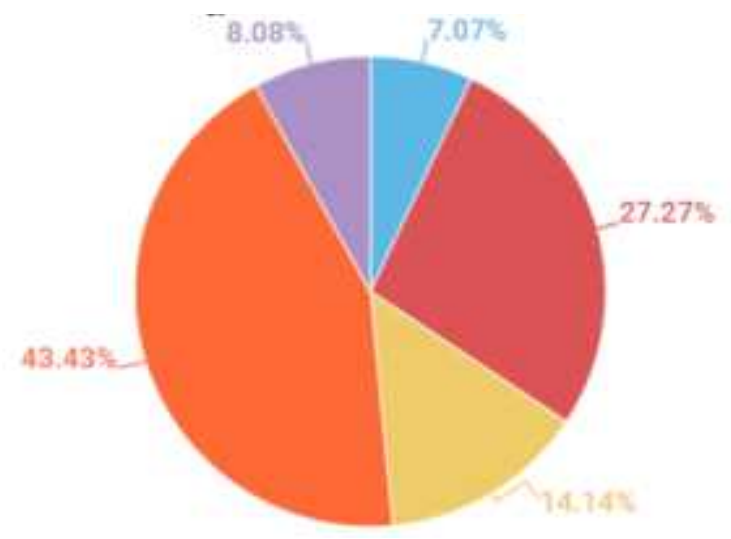

Discordo totalmente

Discordo parcialmente

Indiferente

Concordo parcialmente

Concordo totaimente

Fonte: Autores (2019) 
Além disso, também em relação ao clima, é possível afirmar que, no momento atual, este é um dos fatores que mais desmotiva os profissionais atualmente. Indagados como se sentem hoje, visto na Figura 10 seguinte os principais resultados, diversos entrevistados afirmaram haver o sentimento de insatisfação (15,31\%) e desmotivação $(25,51 \%)$ por diferentes motivos e razões. Dentre eles, destacase a estagnação na carreira, burocratização, politização de cargos, recursos ou infraestrutura incompleta e, ainda, desinteresse dos alunos quanto ao compromisso das aulas e atividades.

Figura 10 - Visão dos profissionais no momento

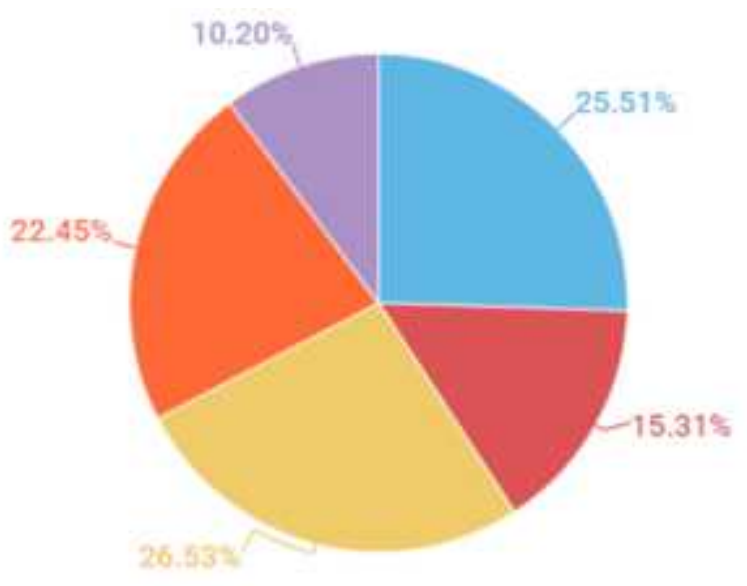

Desmotivado

Insatisfeito

Em progresso

Satisfeito

Motivado

Fonte: Autores (2019)

Além disso, a limitação, falta de estímulos para a execução das funções e o difícil conciliamento dos três âmbitos da educação - ensino, pesquisa e extensão - também são os principais impactantes na desmotivação e insatisfação desses profissionais. Em geral, "os docentes são muitas vezes reprimidos pelas exigências que a realidade educacional lhes atribui e por ideais educativos inalcançáveis, os professores manifestam uma enorme angústia e amplo sentimento de desamparo [...]" (PASCOAL e SILVA, 2018, p.10)

A listagem de itens desmotivacionais em ordem de citações, então, está apresentada abaixo no Quadro2.

Quadro 2 - Fatores desmotivacionais

\begin{tabular}{|l|l|}
\hline 1. Burocracia & 8. Infraestrutura inadequada \\
\hline 2. Politização excessiva & 9. Desvalorização do trabalho \\
\hline $\begin{array}{l}\text { 3. Atuação nos três eixos: ensino, } \\
\text { pesquisa e extensão }\end{array}$ & 10. Clima organizacional \\
\hline 4. Desinteresse dos alunos & 11. Desvalorização do professor \\
\hline 5. Cobrança por publicações & 12. Salário \\
\hline 6. Carga horária sobrecarregada & $\begin{array}{l}\text { 13. Desigualdades na relação aluno- } \\
\text { professor }\end{array}$ \\
\hline 7. Ausência de recursos & 14. Falta de incentivos na pesquisa \\
\hline
\end{tabular}

Fonte: Autores (2019) 
É percebido também que 22,45\% estão satisfeitos com as atividades exercidas e 10,2\% estão motivados com o futuro profissional. Já $26,53 \%$ declararam que sentem que há um grande aprendizado a ser obtido ainda, comprovando, portanto, o resultado mencionado anteriormente quanto ao crescimento profissional na carreira de docência.

Quando os docentes foram questionados sobre o que esperam dos próximos cinco e dez anos de carreira (Figura 11), enquanto que $36,73 \%$ afirmam que esperam se sentir realizado com a profissão que escolheram, realizando sonhos como atingir a liderança de grupos de estudos e pesquisas, execução de projetos com impacto direto em toda a sociedade e o alcance do reconhecimento a nível nacional, outros $36,73 \%$ acreditam que ainda estarão em fase de progressão, ainda tendo que se aprimorarem constantemente até chegarem ao patamar desejado. 19,39\% declararam que, por motivos diversos, estarão estagnados em relação ao presente e não terão tido evolução do presente momento até o futuro e outros 7\% estarão realizando atividades diferentes, como outra carreira ou aposentadoria.

Figura 11 - Visão dos profissionais no futuro

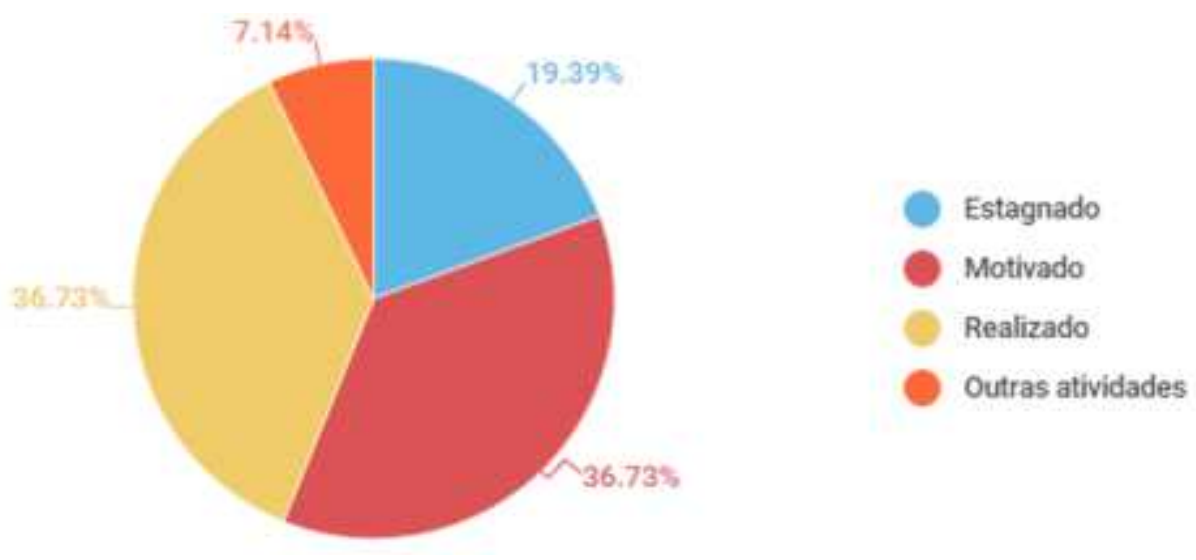

Fonte: Autores (2019)

Para se ter certeza, então, do que mais motiva os profissionais docentes a exercerem carreira em uma universidade federal brasileira, fora questionado qual é o maior atrativo gerando pela carreira aos entrevistados. Como é visto na Figura 12, a estabilidade é o principal fator influente para $57,6 \%$ dos docentes, seguido pela independência $(41,2 \%)$ e o salário $(30,6 \%)$, comprovando, portanto, a teoria da Pirâmide de Maslow, visto que procurar por um emprego estável é uma das prioridades do ser humano e está no segundo de cinco planos.

Figura 12 - Fatores motivantes do ensino público federal

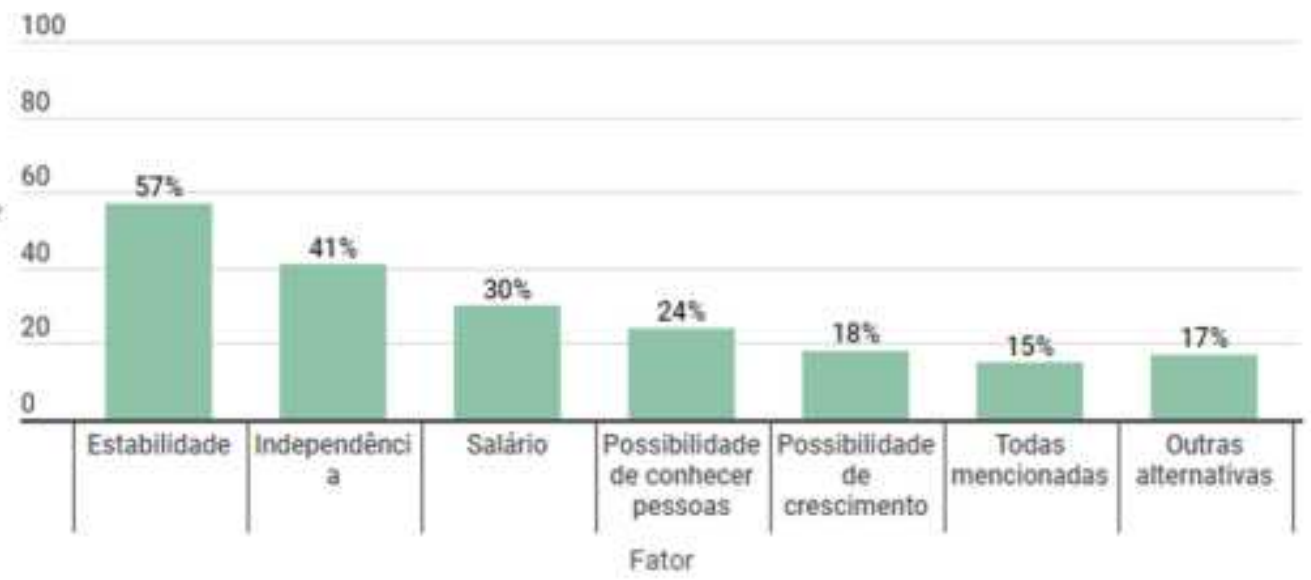

Fonte: Autores (2019) 
Dessa maneira, avaliando todas as respostas obtidas na pesquisa, é possível categorizar os fatores motivantes na listagem exibida no Quadro 3.

Quadro 3 - Fatores motivacionais

\begin{tabular}{|l|l|}
\hline 1. Respeito e ética profissional & $\begin{array}{l}\text { 8. Incentivo à pesquisa e } \\
\text { extensão }\end{array}$ \\
\hline $\begin{array}{l}\text { 2. } \text { Bom } \\
\text { relacionamento } \\
\text { com colegas }\end{array}$ & $\begin{array}{l}\text { 9. Disponibilização de } \\
\text { recursos para a } \\
\text { docência }\end{array}$ \\
\hline 3. Crescimento profissional & 10. Capacitações \\
\hline 4. Trabalho em equipe & 11. Apoio administrativo \\
\hline 5. Plano de carreira & 12. Infraestrutura \\
\hline 6. Liberdade e autonomia & 13. Premiações em geral \\
\hline 7. Valorização à docência & \multicolumn{1}{|l}{} \\
\cline { 1 - 2 } &
\end{tabular}

Fonte: Autores (2019)

Considerando que o lugar onde engendra o ethos é o discurso, pode-se observar que a imagem que os docentes que participaram do estudo tem é de um sujeito realizado ou parcialmente realizado, sobretudo, àqueles que já alcançaram níveis mais altos da carreira, mas com a sensação de que poderia estar melhor, ou ainda, relatam estar bem apesar das dificuldades, como em: "De maneira geral, apesar das dificuldades e restrições orçamentárias da vida acadêmica, me sinto motivado. Tenho alunos educados, atenciosos, motivados e queridos. [...] sigo lutando bastante pelo curso. Não por mim, mas pelo sucesso profissional dos alunos". Desse modo, observa-se um ethos preocupado com o desempenho dos alunos, demonstrando uma postura de responsabilidade social.

Nota-se uma autocrítica e autocobrança em grande parte das respostas dissertativas, o que confirma os dados quantitativos no que tange à preocupação com o próprio desempenho e o de seus alunos. $A$ preocupação com a carreira, em galgar maior posição e recursos para desenvolver pesquisas é outro fator crucial para se compreender o nível de satisfação e motivação. Ethos de autocobrança e frustração por não ter alcançado os objetivos "Poderia ter realizado mais. Insatisfeito".

Por terem optado pela carreira docente e não uma alternativa extra para a escolha profissional, podese depreender que possuem um ethos de realização. Em "Faço aquilo que me realiza", por exemplo, observa um ethos de um sujeito que prioriza a satisfação e não faz o que é contrário aos próprios sentimentos. Porém, os fatores desmotivantes representam uma parcela significativa para a construção de um ethos plenamente realizado. Alguns acreditam que a motivação é mais intrínseca do que extrínseca "Os fatores são mais auto motivacionais do que institucionais". Contudo, analisando todas as respostas juntamente com as questões quantitativas observou-se que fatores extrínsecos interferem tanto na satisfação quanto na motivação dos docentes. Em "Sem oportunidades claras para meu crescimento como profissional" observa-se um ethos tolhido, incapaz de conseguir atingir seus objetivos.

O sentimento de estagnação apontada ao longo da pesquisa se deve ao fato das próprias condições da carreira docente no serviço público, pois não há um crescimento substancial em termos monetários para os níveis de progressão. A relação com os colegas de trabalho também foi destacada " $A$ classe docente é desunida, arrogante e vaidosa", o que contribui para a formação de um ethos de um sujeito 
sem apoio. Outros relataram o desejo de obter parcerias entre os colegas: "Gostaria de ter mais professores daqui desenvolvendo estudos e pesquisas comigo"; com sentimento de frustração e necessidade de haver boa relação de trabalho e ambiente saudável: "Desmotivado principalmente pelas condições do ambiente de trabalho"; Infeliz com a direção do meu campus e com o direcionamento que a universidade escolhe para o ensino, pesquisa, extensão e, principalmente, para a qualificação dos docentes; "Sinto Como se estivesse caminhando num pântano com água lamacenta até os joelhos, no escuro, tomando cuidado para que o ego irredutível de colegas de trabalho não me adoeçam" Faz-se necessário: "Um bom ambiente para trabalhar, boas salas de aulas, colegas motivados e apoio para realização de pesquisa e extensão".

Na pirâmide de Maslow significa o aspecto social, a necessidade de obter boa relação e amizade entre os colegas de carreira. No que diz respeito à valorização e reconhecimento, muitos docentes ressaltaram essa necessidade e se veem não reconhecidos pela instituição onde trabalha, pelos alunos e também pela sociedade. Logo, observa-se a formação de um ethos de "alguém que gosta do que faz e está tentando ser reconhecido pelo que faz"; cercado de: "Burocracia e falta de reconhecimento do governo e da população"; "Subvalorizado como profissional"; frustrado pela "Falta de valorização da carreira"; muitas vezes intimidado pela desvalorização "Com vergonha. Queria ser relevante para os alunos e para a sociedade"; desejo de valorização pelo que faz "valorização coerentes da produtividade do docente"; "Valorização do professor como pesquisador".

A cobrança por parte da administração e também da comunidade têm acarretado em frustração e sentimento de inaptidão e inutilidade diante do quadro complexo que é a educação (PASCOAL e SILVA, 2018, p.4).

De um modo geral, em resumo, há a formação de um ethos que reconhece seu próprio valor e é ciente de que há limitações e obstáculos a serem vencidos: "Me vejo como um profissional esforçado $e$ capaz, porém ciente de que ainda há muito espaço para melhora"; "Sinto que sou uma professora dedicada que busca a todo momento realizar ensino de qualidade, fazer pesquisa e extensão. Entretanto, com defasagem na parte de pesquisa científica, por motivos que não cabem ser mencionados aqui"; "Sinto-me limitado".

\section{Considerações Finais}

As principais dificuldades acadêmicas na compreensão e utilização de dados de um questionário residem possivelmente na pouca exposição de características de seu delineamento para o próprio docente. Este trabalho busca atenuar essa dificuldade, apresentando uma exposição abrangente da participação dos docentes.

Uma vez que o questionário não se mostrou viável em um inquérito de grande porte com toda a comunidade acadêmica da universidade federal, fez-se necessário buscar um método de amostragem estratificada simples nos docentes. Essa estratégia permitiu maior homogeneidade na estratificação, favorecendo a precisão das estimativas que descrevessem a realidade docente na universidade federal em estudo quanto às suas necessidades e a construção de seus ethos.

Dessa maneira, por meio da análise e verificação dos dados obtidos e diante de todo o apresentado, é possível concluir que, de maneira geral, os docentes participantes da entrevista gostam do trabalho que exercem atualmente, procuram formas de crescimento na carreira por meio de pesquisas, participação em projetos de extensãoe, também, realização de cursos e modalidades acadêmicas, como doutorado emestrado. 
Além disso, os docentes também buscam ser criteriosos quanto ao trabalho que exercem, tentando ser empáticos com os colegas, pares e até mesmo com os alunos visto que há uma procura por aplicação de novas metodologias nas aulas, como já abordado anteriormente.

Entretanto, muitos profissionais relataram a presença de fatores específicos desmotivacionais que geram insatisfação e os desagradam em diferentes aspectos e áreas. Alguns desses itens são intrínsecos à profissão e outros à universidade em que estão vinculados, mas todos, cada um com um peso diferente, afetam os docentes de maneira.

Em uma análise do ethos por tempo de profissão dos entrevistados, tanto na universidade em questão quanto em carreira pública em geral, é possível verificar que todos possuem a mesma visão quanto às dificuldades encontradas, como a disposição de recursos e heterogeneidade dos alunos. Porém, é válido destacar que, apesar de não ser uma regra e haver exceções, à medida que o tempo de carreira avança, o grau de motivação quanto ao contínuo aprendizado diminui e a estagnação do docente tende a aumentar por motivos diversos.

Essa conclusão se tornou possível devido a utilização da análise do discurso para interligar as respostas quantitativas e qualitativas obtidas. Esse cruzamento de dados se faz necessário para que as informações possam ser contempladas ao máximo e diferentes aspectos possam ser abordados na disposição dos dados e, por consequência, se consiga responder a problemática do presente trabalho, isto é, tornar possível a determinação do nível de motivação e satisfação dos docentes em uma universidade federal brasileira.

Conclui-se que a satisfação é um motivo intrínseco ao docente, diretamente ligada aos valores e índices de realização pessoal, enquanto que o nível de motivação é regulada pelas necessidades de melhorias destacadas nos resultados. Tais necessidades estão relacionadas em grande parte à valorização e reconhecimento profissional. Sugere-se para pesquisas futuras, investigação acerca da motivação discente para melhor depreender a relação de ensino-aprendizagem e a necessidade de reconhecimento do profissional docente por parte dos discentes. 


\section{REFERÊNCIAS}

AMOSSY, R. Imagens de si no discurso: a construção do ethos. São Paulo: Contexto, 2005. 208 p.

BARTHES, R. L’ancienne rhétorique. Aidemémoire. Communications, n. 16, 1970, p.172-223.

BAUER, M. W.; GASKELL, G. Pesquisa qualitativa com texto, imagem e som: um manual prático. 7. ed. Petrópolis: Vozes, 2008.

BERGAMINI, C. Motivação nas organizações. São Paulo: Atlas, 2008.

BRASIL. Lei no 11.091, de 12 de janeiro de 2005. Dispõe sobre a estruturação do Plano de Carreira dos Cargos Técnico-Administrativos em Educação, no âmbito das Instituições Federais de Ensino vinculadas ao Ministério da Educação, e dá outras providências. Diário Oficial da União. Brasília, DF, 13 jan. 2005. Disponível em: http://www.planalto.gov.br/ccivil_03/_ato2004-2006/2005/lei/l11091.htm. Acesso em: 03 out. 2020.

BRASIL. Lei no 12.772, de 28 de dezembro de 2012. Dispõe sobre a estruturação do Plano de Carreiras e Cargos de Magistério Federal; sobre a Carreira do Magistério Superior, de que trata a Lei no 7.596, de 10 de abril de 1987. Diário Oficial da União. Brasília, DF, 31 dez. 2012. Disponível em: http://www.planalto.gov.br/ccivil_03/_ato2011-2014/2012/lei/l12772.htm. Acesso em: 03 out.2020.

CARDOSO, S. Ciclo de carreira docente: o que dizem as pesquisas brasileiras? In: CONGRESSO NACIONAL DE EDUCAÇÃO, 13, 2017, Curitiba. Anais... Curitiba: Champagnat, 2017. p. 4286 - 4297. Disponível em: http://educere.bruc.com.br/arquivo/pdf2017/24528_13853.pdf. Acesso em: 06 set. 2020.

CAREgnATO, R. C. A; MUTTI, R. Pesquisa qualitativa: análise de discurso versus análise de conteúdo. Texto Contexto Enferm, Florianópolis, v. 15, no 4, 2006, p. 679-684..

CHIAVENATO, I. Administração nos novos tempos. 2. ed. Rio de Janeiro: Elsevier, 2010a.

CHIAVENATO, I. Gestão de Pessoas. 3. ed. Rio de Janeiro: Elsevier, 2010b.

ECHER, I. C. A revisão da literatura na construção do trabalho científico. Revista Gaúcha de Enfermagem, Porto Alegre, v. 22, nㅇ2, 2001, p. 5-20.

FERNANDES, C. A. Análise do discurso: reflexões introdutórias. São Carlos: Claraluz, 2008, 112 p.

FIDLER, B. Staff appraisal: theory, concepts and experience in other organizations and problems of adaptation to education. In: RICHES, C.; MORGAN, C. (Ed.). Human resource management in education. Milton Keynes, UK: Open University Press, 1989.

FREITAS, H. et al. O método de pesquisa survey. Revista de Administração, São Paulo, v. 35, n. 3, p.105-112, 2000.

GREGOLIN, M. R. F. V.. Análise do discurso: conceitos e aplicações. Alfa, São Paulo, v. 39, 1995, p. 13-21.

HERZBERG, F.; AUSNER, B.; SNYDERMAN, B.B. Motivação para trabalhar. Tradução de: Orlando Nogueira. 2. ed. Sydney: John Wiley \& Sons, Inc., 1959. 156 p. Disponível em: http://www.crarj.adm.br/publicacoes/textos_classicos/The_Motivation_to_Work_Traduzido/files/assets/basichtml/index.html\#page1. Acesso em: 25 jul 2020. 
HUBERMAN, M. O ciclo de vida profissional dos professores. In: Huberman, M (Organizador). Vidas de professores. Porto: Porto Editora, 2.ed, 1995, p. 35-46. Disponível em: http://www.uel.br/pessoal/ sreis/pages/arquivos/TEXTOS/IDENTIDADE\%20DE\%20PROFESSORES\%20DE\%20LINGUAS/1995_Novoa_II_Ciclo\% 20de\%20Vida\%20Profissional\%20dos\%20Profs_p_31_46.pdf. Acesso em:03 jun. 2020

INSTITUTO SUPERIOR DE CONTABILIDADE E ADMINISTRAÇÃO DO PORTO. In: A gestão e a sua evolução. In: (Editor). Introdução à gestão: contabilidade e administração, 2014. Disponível em: http://www.aeiscap.com/wp-content/uploads/2014/01/Introdu\%C3\%A7\%C3\%A3o-\%C3\%A0Gest\%C3\%A3o_resumes.pdf. Acesso em: 26 mai. 2020.

JOFRE, A. C. C.; SANTOS, P. C. Teorias Motivacionais. 2015, 17 f. Trabalho de conclusão de curso (Graduação em Gestão de Recursos Humanos) - Fundação Universitária Vida Cristã, Pindamonhangaba, 2015. Disponível em: http://www.bibliotecadigital.funvicpinda.org.br:8080/jspui/bitstream/123456789/334/1/JofreSantos.pdf. Acesso em: 03 out. 2020.

JUNQUILHO, G. S. Gestão e ação gerencial nas organizações contemporâneas: para além do "folclore" e o fato. Gestão \& Produção, São Carlos, v. 8, no 3, p.304-318, dez, 2001.

JURAN, J. M. A qualidade desde o projeto: novos passos para o planejamento da qualidade em produtos e serviços. São Paulo: Cengage Learning, 2015.

LIMA, M. A. M. et al. Funções da gestão educacional: planejamento, organização, direção e controle nas escolas municipais de Aquiraz-CE, Brasil. Revista Eletrônica de Educação, [S. I.], v. 8, no 3, p.127-146, 2018.

MAGALHÃES FILHO, O. V. de; Pereira, V. da C. Gestão de pessoas e seu contexto na sociedade contemporânea. Comunicação \& Mercado, Dourados, v. 1, no 4, p.115-125, 2013.

MARQUES, F.. Gestão de Pessoas: fundamentos e tendências. Brasília: DDG/ENAP, 105, 2015, p.:il

MARRAS, J. P.; TOSE S. Avaliação de desempenho humano. Rio de Janeiro: Elsevier Editora, 2012.

MCCLELLAND, J. A. G. Técnica de questionário para pesquisa. Revista Brasileira de Física, Porto Alegre, v. 1, no 1, p. 93-101, 2019.

MORETTO NETO, L. Funções Administrativas. In: Jacobs N, A. L.; Cruz Júnior, J. B.; Moretto Neto, L. Administração: (Introdução e Teorias). Florianópolis: Sead/UFSC, 2006. 216p. Capítulo 2, 2018, p. 31-62. Disponível em: http://www.cesadufs.com.br/ORBI/public/uploadCatalago/16451216022012Introducao_a_Administracao_Aul a_2.pdf. Acesso em: 02 out. 2020.

OLIVEIRA, J. Empresas na sociedade: sustentabilidade e responsabilidade social. Rio de Janeiro, Elsevier, 2008.

ORLANDI, E. P. Análise de discurso: princípios \& procedimentos. 8. ed. Campinas: Pontes, 2009.

PASCOAL, P.A. G; SILVA, P. C. D.. Riscos psicossociais da atividade docente e análise do discurso: uma investigação acerca da saúde e segurança do professor de educação básica a partir dos princípios da ergonomia. Res., Soc. Dev. 2019; 8(1):e4181619, 2018. ISSN 2525-3409 | DOI: http://dx.doi.org/10.33448/rsd-v8i1.619

PEDRO, D. O. de O. et al.. Importância da motivação dentro das organizações. Revista Ampla de Gestão Empresarial, Registro, v. 1, № 1, p. 60-76, 2018.

REIFSCHNEIDER, M. B. Considerações sobre avaliação de desempenho. Ensaio: avaliação e políticas públicas em educação, Rio de Janeiro, v. 16, no 58, p. 47-58, 2018. 
RIBAS, A.; SALIM, C. R. Gestão de pessoas para concursos. In: (Coordenador). Origem e evolução da gestão de pessoas. Goiânia: Alumnus, 2013. p. 29-49. Disponível em: http://pdf.leya.com/2013/Sep/gestao_de_pessoas_para_concursos_oqgp.pdf. Acesso em:30 set. 2020.

RIOS, G. M.; GHELLI, K. G. M.; SILVEIRA, L. M. Qualidades de um professor universitário: perfil e concepções de prática educativa. Ensino em Re-vista, Uberlândia, v. 23, no 1, p.135-154, 2019.

SÁ, R. A. C. de; SACHETI, S. B. Teorias motivacionais versus qualidade de vida no trabalho. 2015. 60 f. Trabalho de conclusão de curso (Graduação em Administração) - Centro Universitário Eurípides de Marília, Marília, 2015.

SANTOS, G. F. et al. Estilos de liderança: enfoque na teoria X e teoria Y de Douglas McGregor. Universitária-Revista Científica do Unisalesiano, v. 1, n. 2, 2010.

SAKANO, A. M. et al. Avaliação de desempenho: conceito, objetivo e metodologia. Revista Ampla de Gestão Empresarial, Registro, v. 3, no 2, p.100-109, 2014.

SCHERMRHORN JÚNIOR, J. R.; Hunt, J.; Osborn, R. N. Fundamentos de comportamento organizacional. Porto Alegre: Bookman, 1999.

SLACK, N.; BRANDOS-JONES, A.; JOHNSTON, R. Administração da Produção. 8. ed. São Paulo: Atlas, 2018.

SILVA, M. C. M. O primeiro ano de docência: o choque com a realidade. In: ESTRELA, M. T. (Organizador). Viver e construir a profissão docente. Porto: Porto Editora, 1997, p. 53-80. 


\section{IDENTIFICAÇÃO DE FALHAS DE GESTÃO E ORGANIZAÇÃO EM OBRAS DO MUNICÍPIO DE POMBAL-PB COM BASE NOS PRINCÍPIOS DA CONSTRUÇÃO ENXUTA: UM ESTUDO DE CASO}

Raquel Ferreira do Nascimento

Universidade Federal do Rio Grande do Norte

Leonardo de Souza Dias

Universidade Federal do Rio Grande do Norte

Heberton Linhares Damaceno

Instituto Federal da Paraíba

Alice Vitória Serafim Beserra

Instituto Federal da Paraíba

Náthaly Bernardo Sousa

Universidade Federal de Campina Grande

Thomas Mayck Wanderley Melo

Universidade Federal de Campina Grande

\section{RESUMO}

A construção civil é uma das atividades mais importantes para a economia, entretanto é também responsável por grandes impactos ambientais, que se dá tanto pela retirada de recursos naturais do meio ambiente, como pela geração de resíduos, sendo esses muitas vezes descartados de forma inadequada, causando prejuízos à natureza e aos seres humanos. A fim de aliar o progresso da indústria da construção e a preservação do meio, fazse necessário introduzir no processo construtivo, os princípios da construção enxuta que visa o estabelecimento do desenvolvimento sustentável nos canteiros de obra através da reorganização dos mesmos e da instituição de medidas que, se adotadas corretamente, podem promover a otimização de tempo, a diminuição na geração de resíduos, a proteção dos colaboradores e a redução de gastos na obra. Assim, o

\author{
Cibelle Guimarães Silva Severo \\ Universidade Federal da Paraíba \\ Danylo de Andrade Lima \\ Universidade Federal de Campina Grande \\ Maelle Guedes Passos \\ Universidade Federal de Campina Grande \\ Geovany Ferreira Barrozo \\ Universidade de Brasília \\ Bianca Anacleto Araújo de Sousa \\ Universidade Federal Rural de Pernambuco \\ Francisco Ygor Moreira Menezes \\ Instituto Federal da Paraíba
}

objetivo do presente trabalho foi realizar um estudo de caso em 4 (quatro) obras do município de Pombal-PB, a fim de identificar as principais falhas de gestão e organização dos canteiros e propor soluções de otimização de acordo com os princípios da construção enxuta. Foi possível perceber que as principais falhas estão relacionadas à disposição inadequada dos materiais e dos instrumentos no canteiro, bem como a presença de entulho, o desperdício de materiais e a não utilização de EPI's por parte dos colaboradores. A reorganização do canteiro, o planejamento prévio e a conscientização dos trabalhadores são algumas das medidas propostas a fim de reduzir os problemas encontrados.

\section{Palavras-chave:}

Gestão, organização, construção enxuta, meio ambiente.

\section{ABSTRACT}

Civil construction is one of the most important activities for the economy, however it is also responsible for great environmental impacts, which occur both by removing natural resources from the environment and by generating waste, which is often improperly discarded, causing damage to nature and human beings. In order to ally the progress of the construction industry and the preservation of the environment, it is necessary to introduce in the constructive process, the principles of lean construction that aims at the establishment of sustainable development in the construction sites through the reorganization of the same and the institution of measures that, if adopted correctly, can promote the optimization of time, the decrease in the generation of residues, the protection of the collaborators and the reduction of expenses in the construction site. Thus, the objective of the present work was to carry out a case study in 4 (four) works of the city of Pombal-PB, in order to identify the main failures in the management and organization of the construction sites and to propose optimization solutions according to the principles of lean construction. It was possible to notice that the main flaws are related to the inadequate disposal of materials and instruments on the site, as well as the presence of rubble, waste of materials and non-use of PPE by employees. The reorganization of the yard, the previous planning and the workers' awareness are some of the measures proposed in order to reduce the problems found.

\section{Keywords:}

Management, organization, lean construction, environment. 


\section{INTRODUÇÃO}

A construção civil é uma das indústrias mais relevantes para o desenvolvimento econômico. No entanto, é considerada como uma das atividades mais geradoras de impactos ambientais, utilizando cerca de 20 e $50 \%$ dos recursos naturais consumidos (JOHN, 2000).

Além de utilizar uma enorme quantidade de recursos naturais o processo construtivo caracteriza-se pela elevada produção de resíduos decorrentes das atividades executadas na construção. Dessa forma, a Resolução CONAMA no 307, de 5 de julho de 2002, estabelece responsabilidades e deveres para a gestão dos resíduos da construção civil (RCC), definindo obrigações dos geradores para disposição e tratamento dos RCC's.

Visando conciliar o crescimento da indústria da construção civil com a preservação do meio ambiente, é necessário enquadrar os princípios construtivos no conceito de desenvolvimento sustentável, fazendo uso dos recursos naturais de maneira consciente e, diminuindo a agressão ao meio ambiente (PINTO, 2005).

Nesse contexto, surge a Construção Enxuta, que visa, além de reduzir o uso desenfreado dos recursos naturais e a geração de resíduos, proporcionar maior eficiência e produtividade a atividade construtiva. Dessa maneira, os seus princípios englobam não apenas a produção, mas o negócio como um todo, compreendendo o desenvolvimento do produto, a relação com os fornecedores, as vendas e a gestão de pessoas (PICCHI, 2003). Está relacionada, então, a um gerenciamento eficiente de todos os fatores envolvidos em uma obra, de forma a gerar benefícios tanto para o meio ambiente como para àqueles envolvidos no processo construtivo.

Diante disso, o presente trabalho tem por objetivo diagnosticar as falhas relacionadas a gestão ou execução de obras em 4 (quatro) canteiros do município de Pombal-PB e sugerir possíveis soluções para a minoração das mesmas, baseando-se nos princípios da construção enxuta, visando a melhoria na produtividade, na eficiência e a redução de impactos ambientais.

\section{Referencial Teórico}

A construção civil é um dos setores que apresentam maiores índices de geração de resíduos, sendo uma atividade bastante comprometedora para o meio ambiente. Além disso, a utilização de recursos naturais é constante na indústria da construção, visto que, os mesmos são utilizados como matériaprima para o desenvolvimento de materiais destinados ao processo construtivo. Isso proporciona a degradação de áreas naturais.

No entanto, a atividade construtiva é fundamental para o desenvolvimento social e econômico da sociedade. Segundo o DIEESE (2020), o setor da construção Civil teve participação de 3,7\% do PIB em 2019, mantendo cerca de 6,38 milhões de ocupados no Brasil. Por essa razão, faz-se necessário conciliá-la com a preservação do meio ambiente, de maneira tal que, a humanidade não sofra as possíveis consequências decorrentes da negligência para com o mesmo. É necessário, então, aliar-se ao conceito de desenvolvimento sustentável, permitindo o equilíbrio entre o progresso econômico ea 
preservação da natureza, de forma que, seja possível para gerações futuras, desfrutarem do meio sem maiores consequências. (FERREIRA et at., 2008).

Nesse cenário, surge o conceito de construção enxuta que deriva do modelo para gestão de produção Lean Production (Produção Enxuta), advindo do Sistema Toyota de Produção. Esse modelo aplicado a construção Civil proporciona maior eficiência e produtividade a atividade construtiva, permitindo a redução dos resíduos gerados e a consequente redução dos impactos causados pelo setor. Consiste em um modo eficaz de gestão que permite o melhoramento da produção, com redução do tempo de trabalho, dos gastos, dos desperdícios e da geração de resíduos.

A Construção Enxuta, baseia-se no planejamento prévio e organização do canteiro de obras, de maneira a tornar o trabalho mais produtivo. A gestão não se restringe apenas a etapa de execução da obra, mas envolve uma gama de fatores que devem ser verificados antes do início da construção, incluindo, nesse aspecto, a disposição dos materiais no local e a segurança dos colaboradores. Está relacionada, então, a um gerenciamento eficiente de todos os fatores envolvidos em uma obra, de forma a gerar benefícios tanto para o meio ambiente como para àqueles envolvidos no processo construtivo.

É possível estabelecer uma nítida diferença entre os processos construtivos convencionais e os que aplicam um modelo de gestão baseado na Construção Enxuta. No modelo convencional a produção ocorre apenas com a análise das atividades que agregam valor, sem considerar o processo como um todo (REIS et al., 2015). Já na Construção Enxuta, a produção envolve todos os acontecimentos durante o processo, desde a seleção da matéria prima até o produto final (FORMOSO, 2002). O planejamento desde o início das atividades possibilita maior desempenho na execução das obras de forma a permitir progresso e eficiência. Koskela (1992) define onze princípios da construção enxuta, são eles:

a) Redução de parcela de atividades que não agregam valor;

b) Aumento no valor do produto;

c) Redução a variabilidade;

d) Redução no tempo de ciclo;

e) Simplificação e minimização do número de passos ou partes;

f) Aumento da flexibilidade de saída (produto);

g) Aumento da transparência do processo;

h) Foco no controle e no processo global;

i) Introdução de melhoria no processo;

j) Balanceamento das melhorias no fluxo com as melhorias das conversões;

k) Benchmarking.

A inserção desses conceitos alcança vantagens como o aumento de produtividade e de competitividade, maior estabilidade dos processos produtivos, redução no tempo de execução das atividades e de custos de produção, redução de riscos, melhor organização e redução de desperdícios no canteiro de obras, maior controle de fluxos e aumento da satisfação das equipes de trabalho e clientes finais (REIS et al.,2015).

Diante disso, é possível perceber a importância de introduzir esse modelo de gestão sustentável nas construções. A manutenção de um modelo tradicional pode comprometer a obra e o meio ambiente. Como foi descrito, a adoção de um sistema sustentável de produção gera inúmeros benefícios e possibilita a conciliação entre desenvolvimento econômico/social e meio ambiente. 


\section{Metodologia}

O presente trabalho caracteriza-se como sendo exploratório e descritivo. Segundo Vieira (2002), "A pesquisa exploratória visa proporcionar ao pesquisador uma maior familiaridade com o problema em estudo. Este esforço tem como meta tornar o problema complexo mais explícito ou mesmo construir hipóteses mais adequadas". A descritiva está interessada em descobrir e observar fenômenos, procurando descrevê-lo, classificá-los e interpretá-los.

Dessa forma, o estudo em questão é de natureza aplicada, pois está direcionada à aquisição de conhecimentos buscando a elucidação de problemas por meio de aplicações práticas (SILVA, 2004).

Foram realizadas visitas de campo a 4 (quatro) obras, nas quais foi possível diagnosticar as principais falhas relacionadas a gestão das mesmas, o que permitiu definir sugestões para a melhoria, baseando-se nos princípios da Construção Enxuta, a fim de reduzir os resíduos gerados, bem como o impacto desses sobre o meio ambiente. Além de possibilitar a otimização do tempo, redução de gastos e aumento do lucro.

\section{Resultados e Discussões}

Nas visitas realizadas às obras selecionadas do município de Pombal-PB, observou-se as principais características dos canteiros, tais como a organização, os desperdícios, a disposição dos materiais, o fluxo dos trabalhadores e a segurança dos mesmos.

\subsection{Caracterização das obras e falhas identificadas}

1ạ obra: A construção (Figura 1), com $90 \mathrm{~m}^{2}$ de área, encontrava-se na etapa de acabamento, contando com 4 (quatro) colaboradores que possuíam funções definidas. Os mesmos trabalhavam 8 (oito) horas diárias com 2 (duas) horas livres para o almoço. Sendo assim, o expediente iniciava-se as 7:00 e encerrava-se às 11:00, na parte da manhã e retornava às 13:00 encerrando-se às 17:00 horas. 0 período de descanso ocorria nas próprias residências dos trabalhadores, por ser mais cômodo e próximo ao local de trabalho.

Figura 1 - Croqui da obra 1
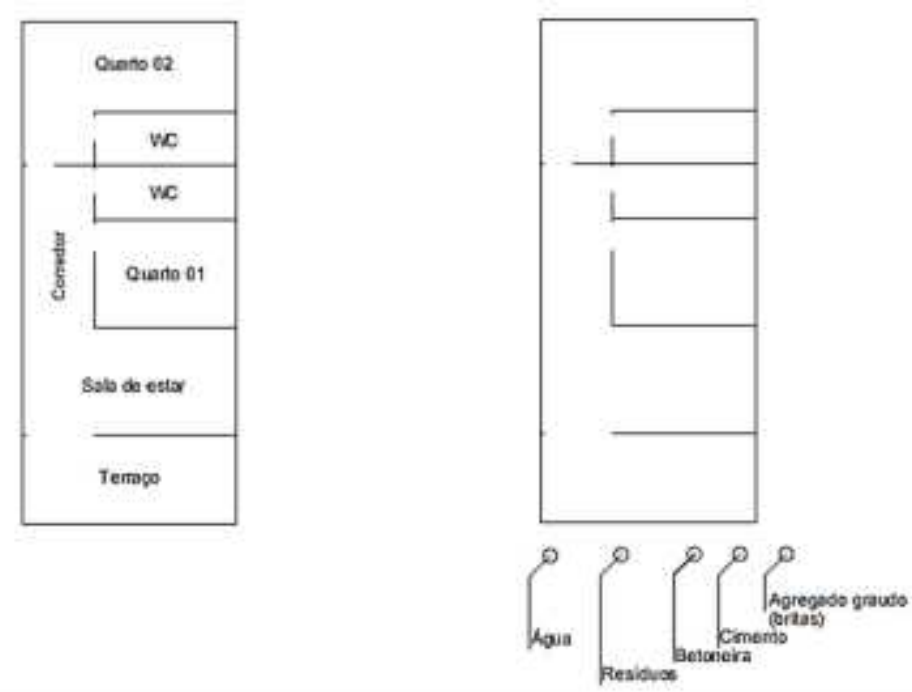
Ao realizar a visita no local da obra foi possível identificar determinadas falhas na organização e gestão da construção, em especial a falta de limpeza no próprio local, de forma a apresentar resíduos na frente (Figura 2), bem como na lateral da obra (Figura 3), o que proporcionava dificuldade de locomoção dos trabalhadores, correndo riscos de sofrer algum tipo de ferimento. Além disso, o acúmulo de resíduos consistia em um grande atrativo para proliferação de animais transmissores de doenças.

Figura 2 - Resíduos na área frontal da obra.

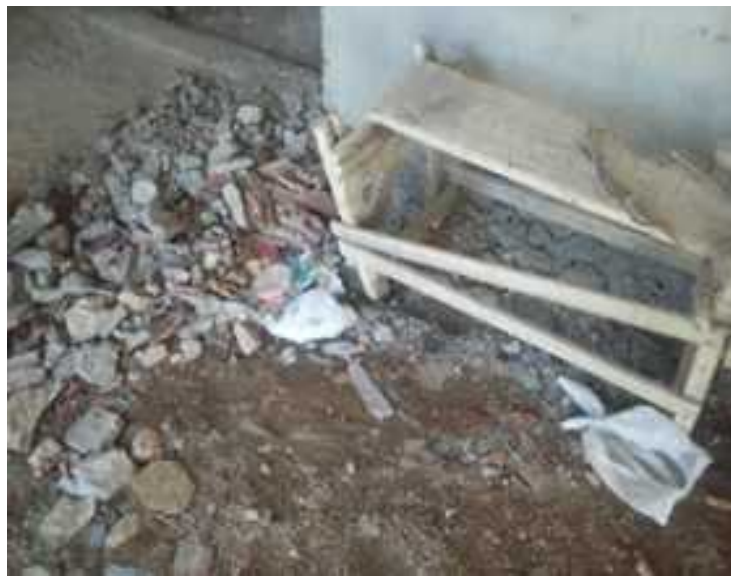

Figura 3 - Resíduos na área lateral da obra.

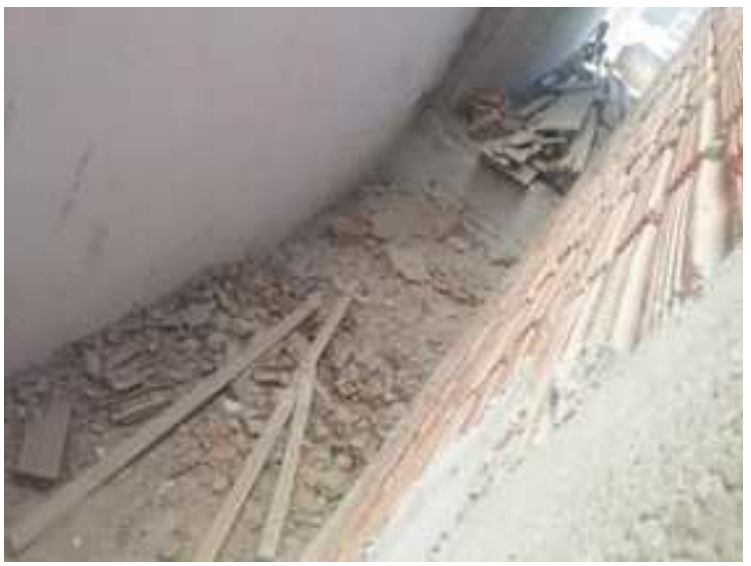

Observou-se também o desperdício de material gerado durante a execução da alvenaria, visto que, foi possível notar a quantidade desnecessária do material entre os tijolos ou espalhado no chão. Na alvenaria é possível ainda perceber a irregularidade na quantidade de material entre os tijolos, de forma que, entre alguns há uma parcela generosa de argamassa, enquanto entre outros, quase não há (Figura 4).

Figura 4 - Desperdício de material e irregularidade de seu uso.

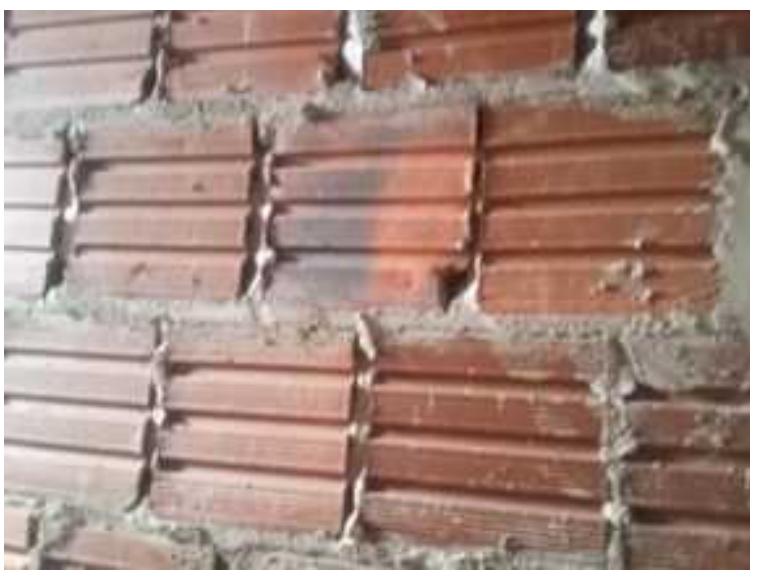

Além disso, percebeu-se a desorganização de determinados materiais utilizados (Figura 5), que se apresentavam "jogados" na parte interior da obra. A betoneira (não aterrada), areia, brita, cimentos, caixa d'água e demais materiais utilizados no processo construtivo se encontravam dispostos do lado de fora da construção (Figura 6), ocupando parte da rua, o que dificultava a passagem de transportes e pedestres, bem como dos próprios trabalhadores. Isso gerava um atraso (ainda que pequeno) no processo construtivo. Os colaboradores não utilizavam os Equipamentos de Proteção Individual (Epi's), correndo sério riscos de segurança, podendo estes comprometer a saúde e integridade física dos mesmos. 
Figura 5 - Materiais dispostos de forma desorganizada na área interna.

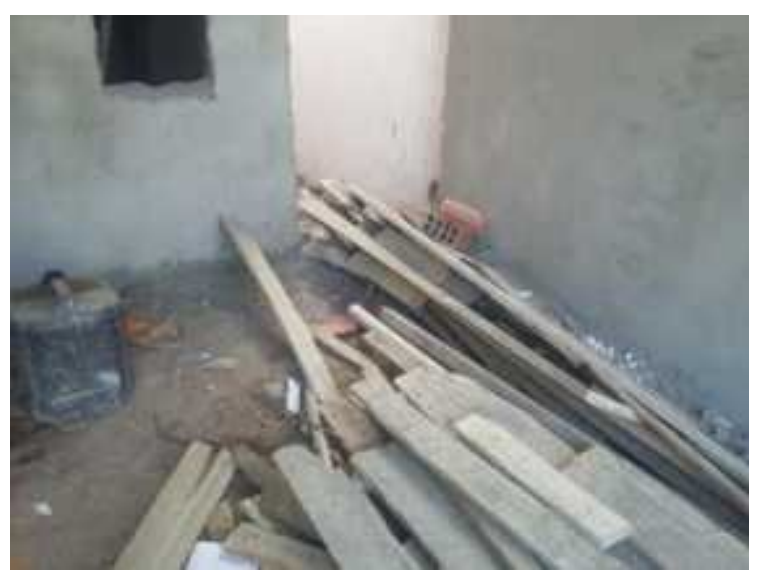

Figura 6 - Materiais dispostos na área externa e ocupando parcela da rua.

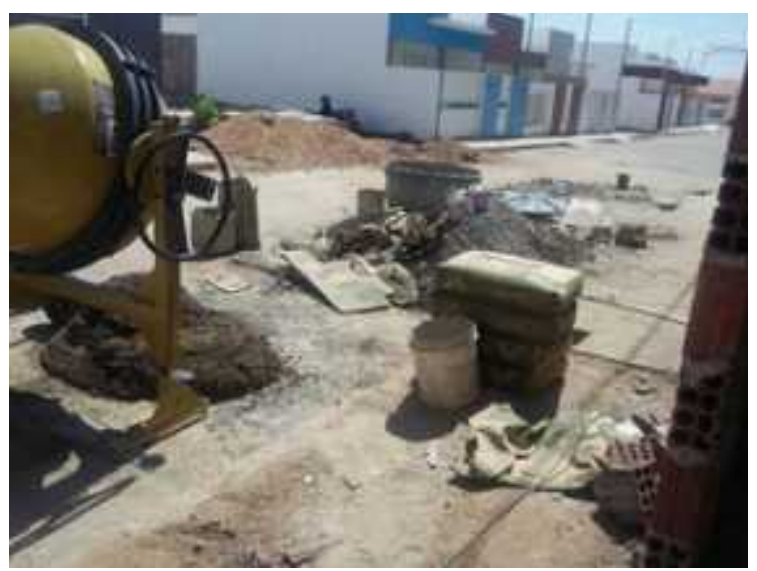

2a obra: A construção, com $90 \mathrm{~m}^{2}$ de área, encontrava-se na etapa de fundação, contando com 4 (quatro) colaboradores. Os mesmos trabalhavam 8 (oito) horas diárias com 2 (duas) horas livres para o almoço e descanso. Sendo assim, o expediente iniciava-se as 7:00 e encerrava-se às 11:00, na parte da manhã e retornava às 13:00 encerrando-se às 17:00 horas. O período de descanso ocorria nas residências dos trabalhadores.

Ao realizar a visita no local da obra foi possível identificar alguns problemas relacionados a organização do canteiro. Primeiramente, alguns instrumentos de trabalho estavam dispostos de forma desordenada (Figura 7) nas proximidades do local de execução, o que podia, de certa forma, dificultar o acesso a determinado item além de criar um ambiente desagradável e desorganizado.

Como a construção ainda se encontrava na etapa de fundação, não era possível guardar os materiais dentro da obra, sendo, então, deixados expostos. A exposição de materiais (Figura 8) a condições ambientais (sol, chuva, vento) pode comprometer a qualidade destes, o que interfere na construção. Além disso a betoneira encontrava-se não aterrada, gerando riscos para quem a manuseava. 
Figura 7 - Instrumentos desorganizados

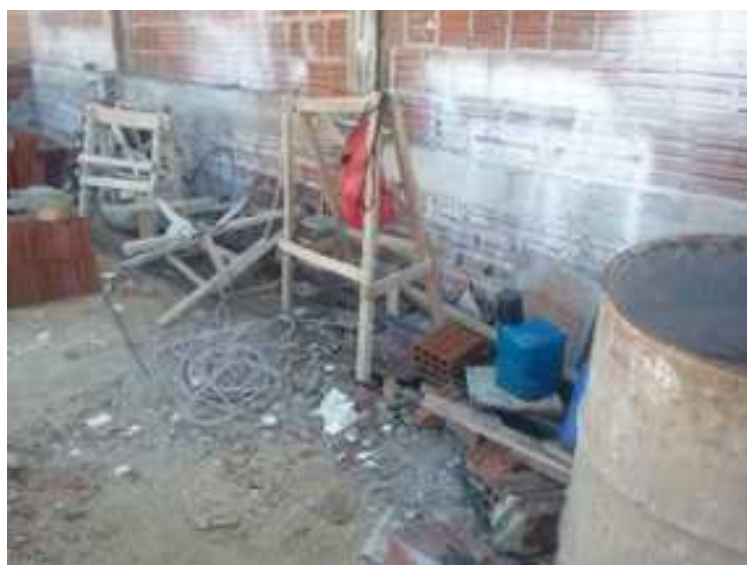

Figura 8 - Exposição dos materiais

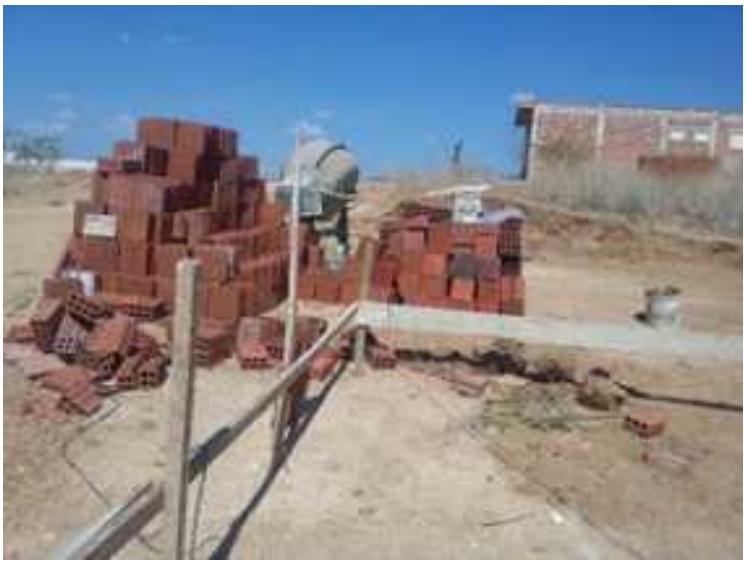

A energia utilizada na execução das atividades era adquirada da residência ao lado e a água era encanada. Segundo o mestre de obra da construção, a compra de materiais é feita quando há a falta desses, não havendo, portanto, um planejamento prévio da quantidade necessária e do período de compra, interferindo, ainda que minimamente, no tempo de execução da construção.

Outra falha identificada foi a distância dos materiais e da betoneira até o local onde se estava desenvolvendo as atividades. Isso dificultava o transporte dos materiais e aumentava o tempo gasto com a locomoção, tornando o processo mais demorado. A Figura 9 apresenta esse problema.

Figura 9 - Croqui da obra apresentando a disposição dos materiais.
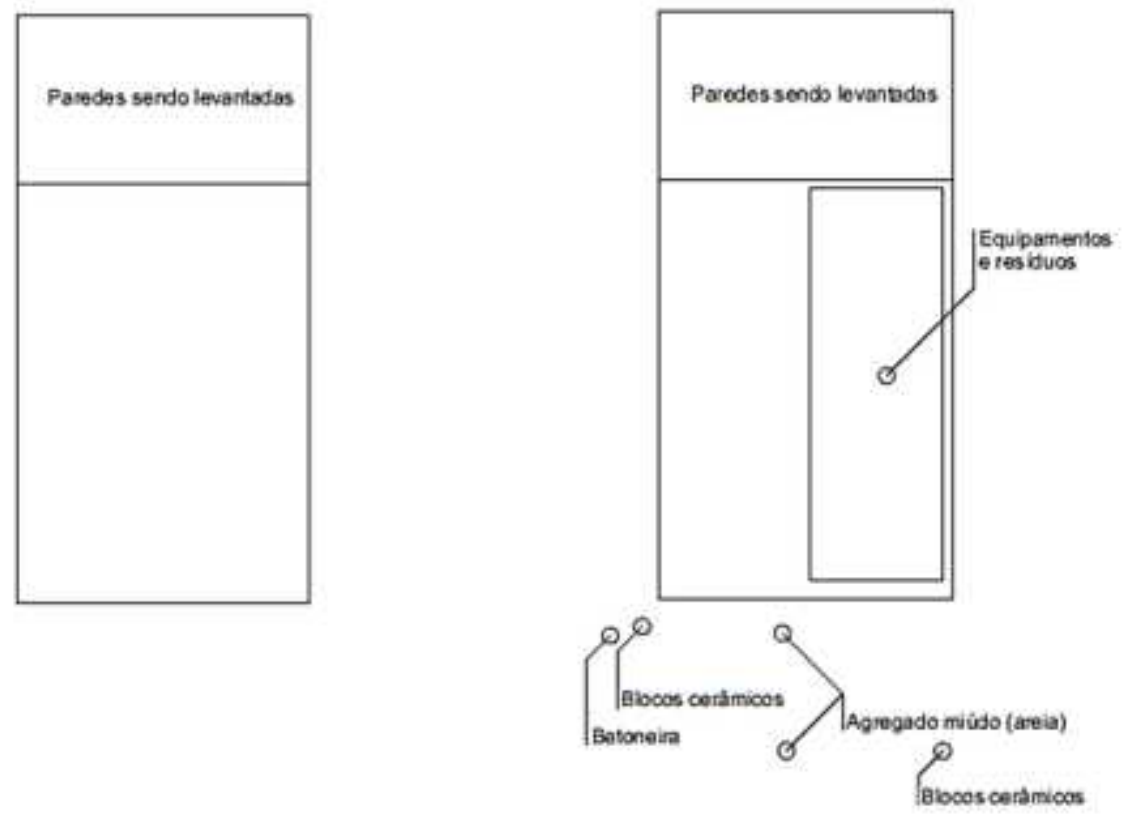

Os colaboradores não utilizavam EPI's (Equipamentos de Proteção Individual) ficando sujeitos a acidentes decorrentes do trabalho. Os resíduos da construção eram deixados na frente da obra para serem recolhidos por um caminhão destinado a retirar entulhos das ruas. 
3ạ obra: A construção (Figura 10), com $95 \mathrm{~m}^{2}$ de área, encontrava-se na etapa de acabamento, contando com 6 (seis) colaboradores que possuíam funções definidas. Os mesmos trabalhavam 9 (nove) horas diárias com 1 (uma) hora e meia livre para o almoço e descanso. Sendo assim, o expediente iniciava-se as 6:30 e encerrava-se às 11:00, na parte da manhã e retornava às 12:30, encerrando-se às 17:00 horas. 0 período de descanso ocorria nas próprias residências dos trabalhadores.

Figura 10 - Croqui da obra 3.
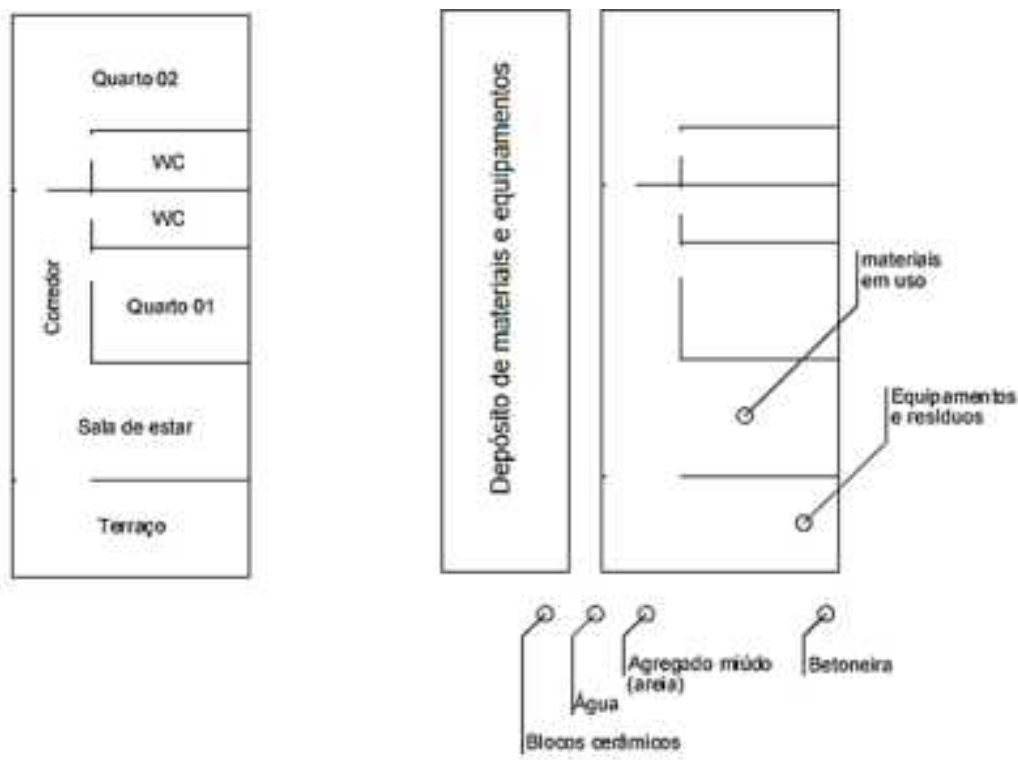

Os problemas identificados no local foram sobretudo relacionados ao desperdício de material e a disposição dos mesmos, além da falta de segurança dos colaboradores. Observou- se um grande desperdício de material nas alvenarias (Figura 11), de forma que a argamassa se apresentava em uma proporção exagerada entre os tijolos, excedendo o padrão necessário para se fazer a aderência entre eles. No entanto, nota-se também que enquanto em uma parte da alvenaria havia desperdícios, na outra havia pouquíssimo ou nenhum material, levando a uma ausência de regularidade e padrão. Na etapa de reboco, uma alternativa que os trabalhadores encontraram para utilizar o material que caia no chão, foi colocar uma tábua que podia apará- lo (Figura 12). Isso permitia que o material que seria desperdiçado fosse empregado novamente na obra.

Figura 11 - Desperdício de material e irregularidade de seu uso.

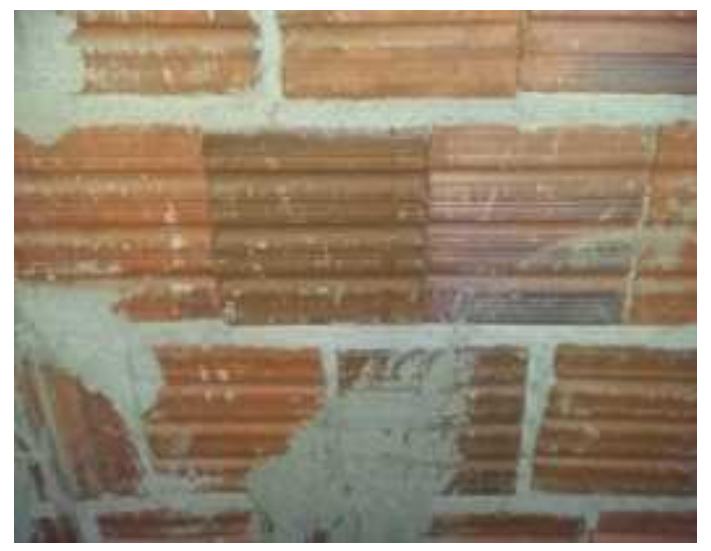


Figura 12 - Tábua aparando o material que cai.

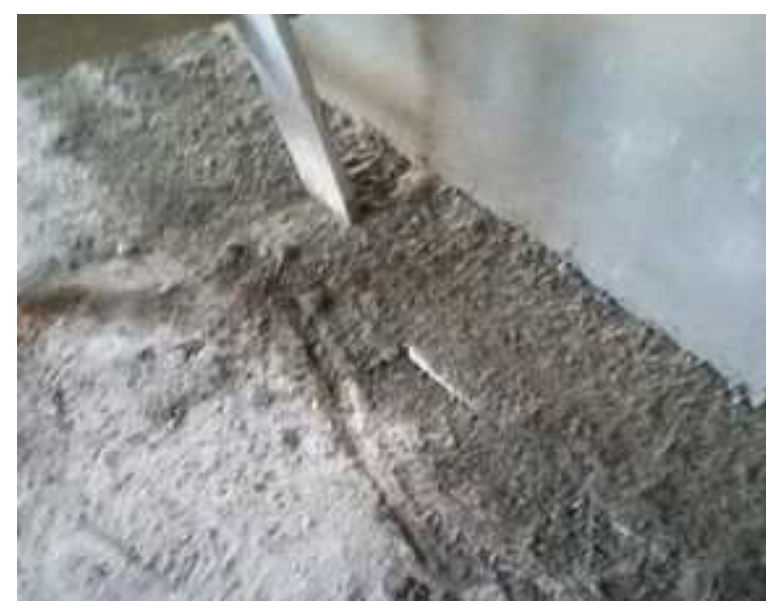

Os materiais eram dispostos na área externa da construção, e ocupavam a frente da obra e parte da frente da casa vizinha (Figuras 13 e 14). Além de interromper a passagem de pedestres e veículos, já que boa parte da rua também ficava ocupada. Nenhum material era guardado no período da noite, até mesmo a betoneira permanecia do lado de fora. A distância entre os materiais e o local do trabalho também se constituía em uma falha de gestão, aumentando o tempo gasto com o transporte dos mesmos.

Ao realizar a visita, percebeu-se que no local onde estava se desenvolvendo a atividade, alguns sacos de cimento e um carrinho de mão com a argamassa estavam ocupando uma área central, dificultando a locomoção dos colaboradores (Figura 15). Notou-se também uma certa quantidade de entulho presente na área interna da obra (Figura 16), onde o trabalho estava sendo executado.

Segundo o mestre de obra, o material era reposto a cada 11 (onze) ou 15 (quinze) dias, de forma que a construção não parava por falta do mesmo. Antes que acabasse, o pedido de uma nova remessa já era feito. A água utilizada na construção vinha de um poço localizado a 150 (cento e cinquenta) metros da obra e era puxada por uma bomba até chegar à localidade onde ficava armazenada em caixas d'água. O problema ocorria quando faltava água no poço, já que, se era necessário contratar um caminhão pipa para abastecer o local. Isso acarretava em um acréscimo no custo da obra. Os colaboradores não utilizavam EPI's, ficando sujeitos acidentes decorrentes do trabalho.

Figura 13 - Vista frontal da obra.

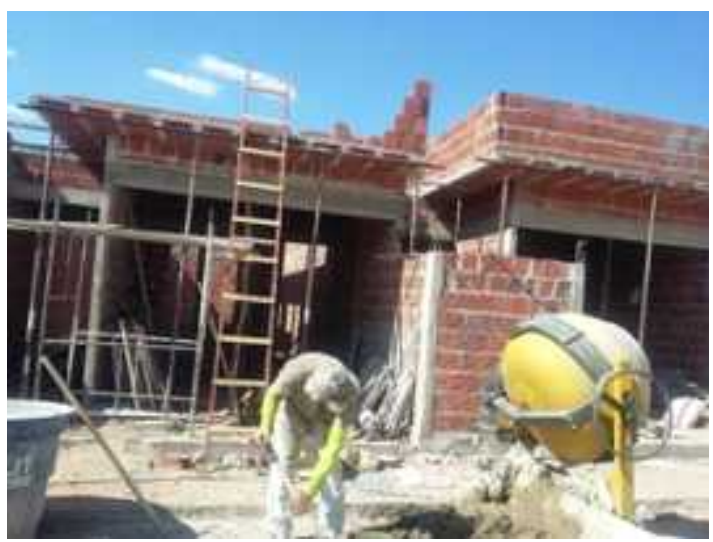

Figura 14 - Disposição dos materiais (área externa).

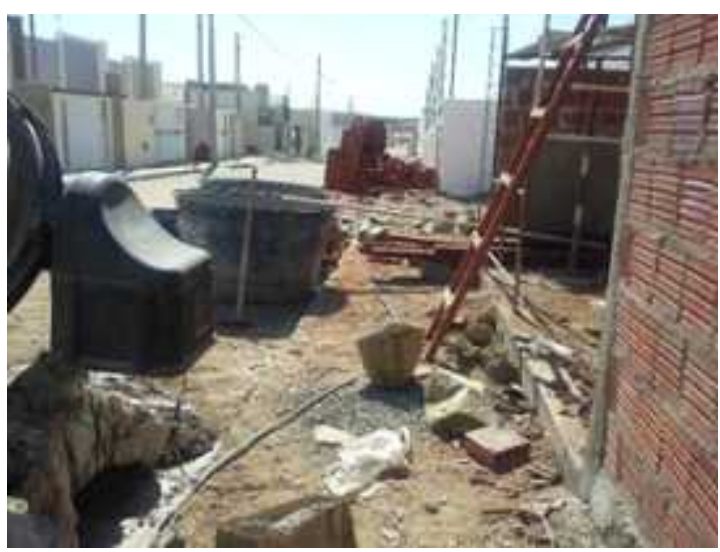


Figura 15 - Materiais dispostos na área interior, atrapalhando a passagem.

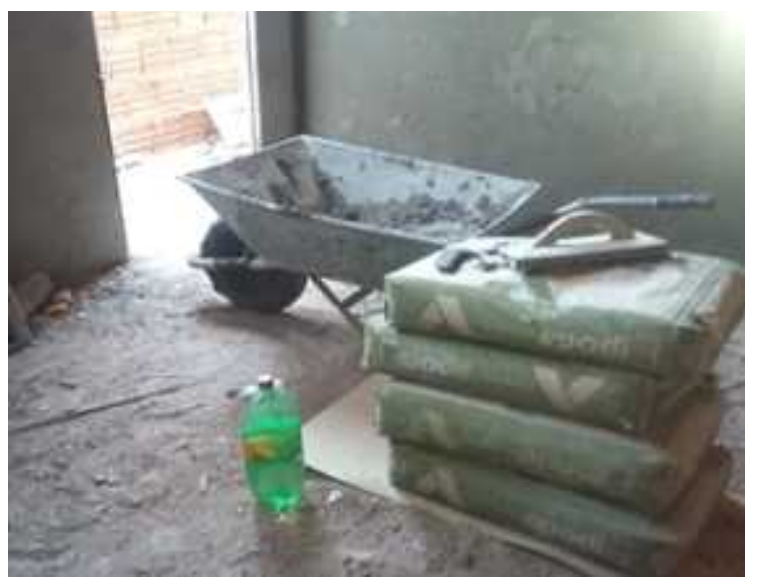

Figura 16 - Presença de entulho na área de trabalho.

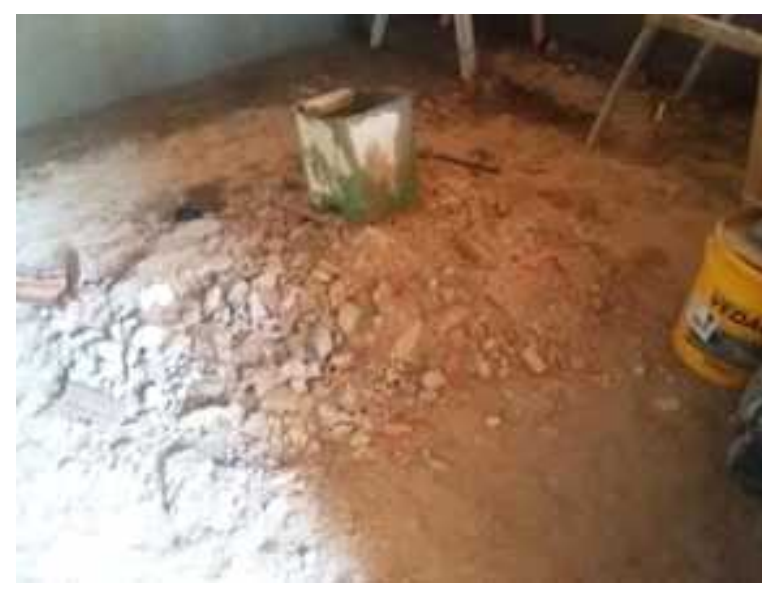

4ạ obra: A obra possui uma área total de 2484,88 m2 (Figura 17), sendo que destes, $1312 \mathrm{~m} 2$ são de área construída. A construção do empreendimento contava com um número total de 6 (seis) colaboradores. Os mesmos trabalhavam 9 (nove) horas diárias com 1 (uma) hora e meia livre para almoço e descanso. Sendo assim, o expediente iniciava-se as 7:00 e encerrava-se às 11:30, na parte da manhã e retornava às 13:00 encerrando-se às 17:30 na parte da tarde. 0 período de descanso ocorria nas próprias residências dos trabalhadores, com exceção do mestre de obra que residia na zona rural e permanecia no próprio local da construção durante esse período.

Figura 17 - Croqui da obra 4.

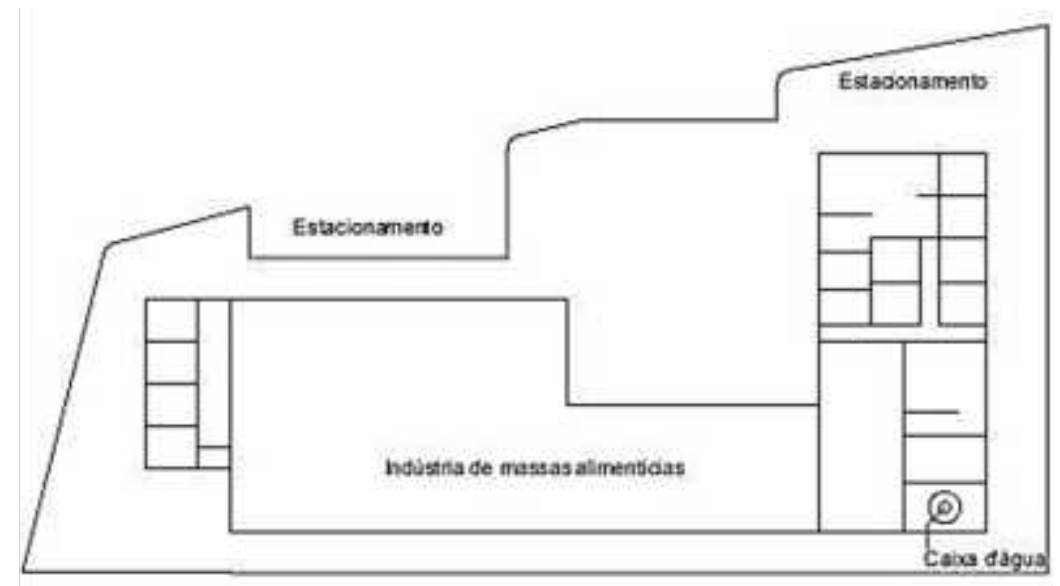


Diante da análise realizada no empreendimento, foi possível identificar certas falhas de gestão e impactos ambientais relevantes como a retirada da vegetação local (Figura 18) devido o processo de terraplanagem. $O$ desperdício de materiais também se fez presente em razão do excesso dos mesmos para corrigir os desníveis da alvenaria, a exemplo da argamassa.

No início da construção os materiais estavam localizados na área externa da obra (Figuras 19 e 20) o que dificultava o transporte dos mesmos, levando a um maior gasto de tempo. Porém, depois os materiais e instrumentos de trabalho foram dispostos no interior da construção (Figura 21), estando mais próximos do local de trabalho e permitindo maior agilidade. O problema era como eles estavam organizados dentro da obra, visto que, apesar de se encontrarem próximos do local de trabalho, dificultavam ofluxo dos colaboradores.

A água, fornecida pelo sistema de abastecimento público era armazenada em um tanque provisório (Figura 23), construído para facilitar o acesso ao recurso no próprio canteiro de obras e a energia elétrica era adquirida no galpão vizinho. Havia acúmulo de resíduos no canteiro de obras (Figura 22), o que se constituía em um empecilho para o bom fluxo e desempenho, além de ser um atrativo a seres causadores de doenças. Ademais, os colaboradores da obra não faziam uso de EPI's (Equipamento de Proteção Individual) e EPC's (Equipamento de Proteção Coletiva), ficando suscetíveis à acidentes de trabalho.

Figura 18 - Área sem vegetação.

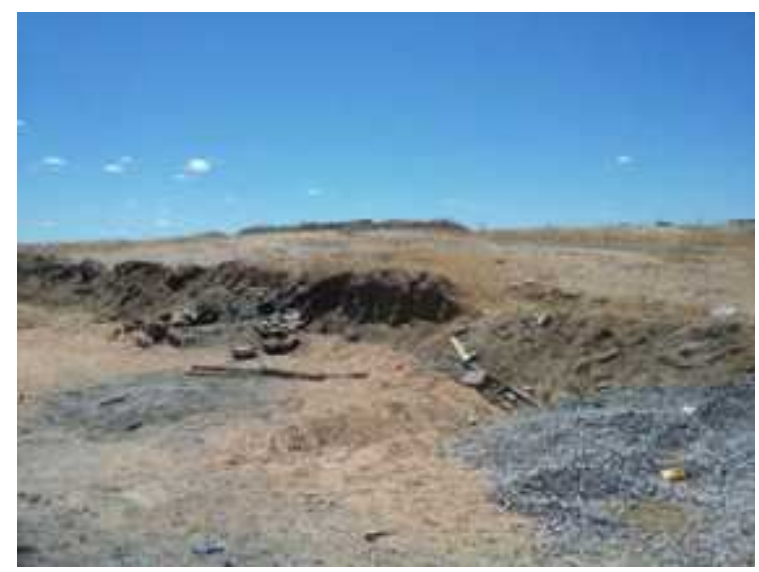

Figura 19 - Transporte da betoneira.

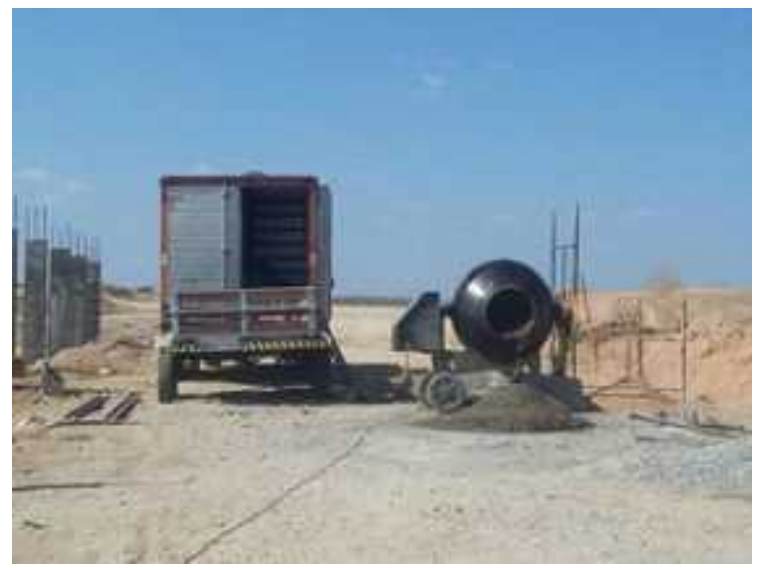

Figura 20 - Armazenamento e disposição dos materiais (no início).

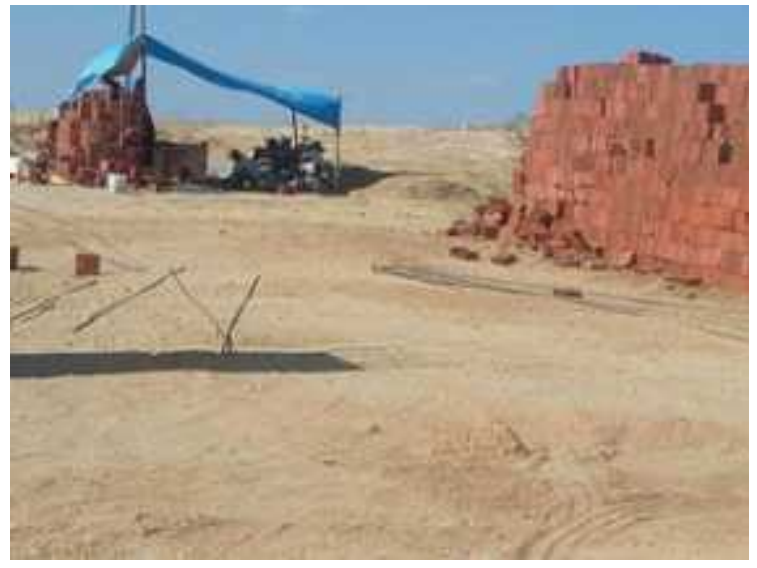


Figura 21 - Armazenamento e disposição dos materiais no interior.

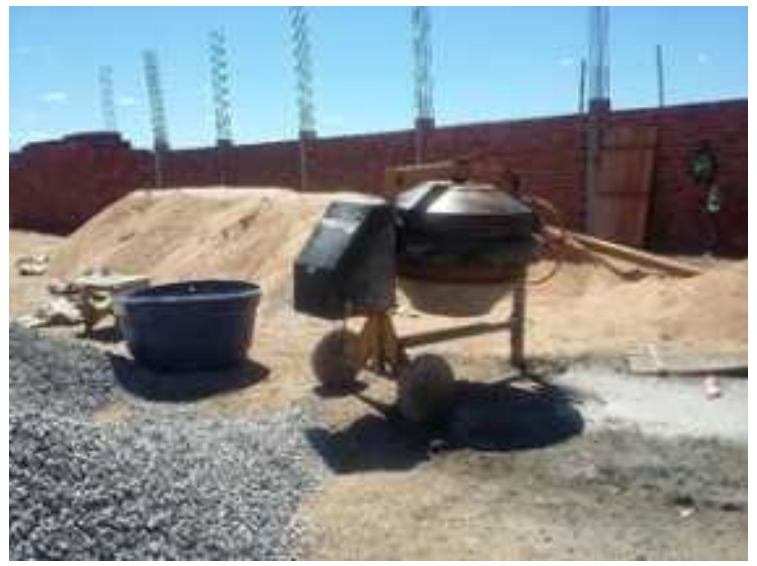

Figura 22 - Entulho.

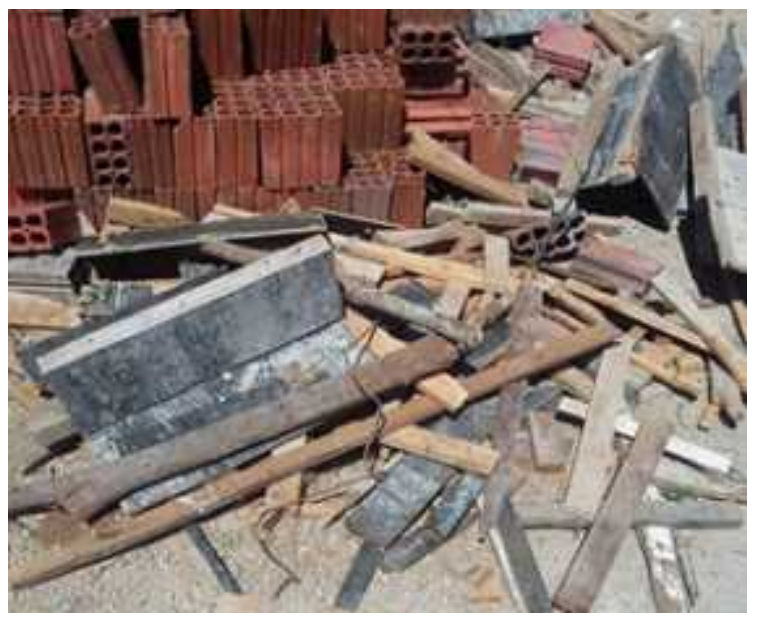

Figura 23 - Armazenamento de água.

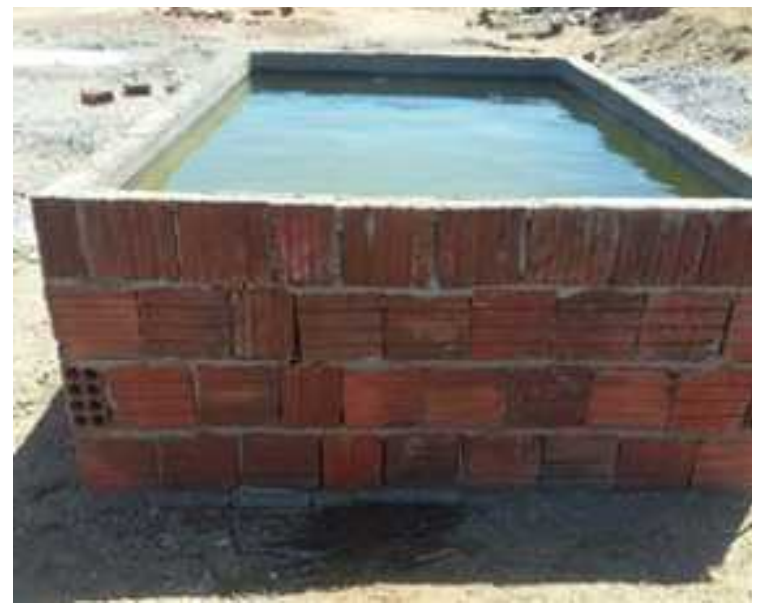

\subsection{Soluções para as falhas de gestão}

Diante do exposto, é possível destacar possíveis soluções para as falhas apresentadas, baseando-se no modelo de gestão que utiliza os princípios da construção enxuta. Primeiramente, para as obras que apresentavam entulho dentro da própria construção, é necessário realizar a limpeza. A falta desta, além de dificultar o fluxo dos colaboradores, constitui-se em um foco de proliferação de seres que transmitem doenças. Ao término de cada atividade, os resíduos devem ser deslocados para um espaço reservado, e ao fim do dia já devem ser levados ao local de destino (aterros, ou reciclagem). Os resíduos não devem permanecer durante muito tempo no canteiro.

Quanto ao desperdício de material, é necessário conscientizar os colaboradores acerca da quantidade necessária a ser utilizada, de forma que reduza os desperdícios e os consequentes gastos adicionais. Assim, uma fiscalização diária por parte do responsável também seria útil, a fim de verificar se o uso está sendo feito de forma correta.

Outro fator notado na maior parte das obras visitadas foi a disposição dos materiais. Em algumas, estes estão dispostos na área externa da construção, dificultando a passagem de quem circula pela rua, bem como dos colaboradores da obra. De fato, a maioria das construções são pequenas e não apresentam um 
local adequado para a disposição dos materiais no interior, mas pelo menos uma parte deles deveria ser levada para a área interna em um local reservado, onde não se esteja construindo e que não interrompa o fluxo. Isso desocuparia uma parte da rua, além de o material ficar mais próximo da área de atividade, reduzindo o tempo de transporte do mesmo. Nas obras onde o material (ou parte dele) encontrava-se disposto no interior, foi possível perceber que o mesmo estava situado em locais que comprometiam a passagem. É necessário realoca-los para regiões livres de fluxo.

O planejamento prévio da quantidade de material a ser utilizada também se constitui em uma medida importante. Uma alternativa é fazer o cálculo prévio do material necessário para um tempo limite (a cada duas semanas, por exemplo). Em um cronograma, colocar a quantidade recebida, o dia de recebimento e quando será necessário fazer a reposição (com antecedência), de forma que não falte material, a fim de manter o progresso da obra. É imprescindível cumprir o prazo de entrega. Os gastos adicionais como a compra de água, instrumentos de trabalho e outros materiais devem estar inclusos no orçamento da obra, evitando gastos não planejados.

E por fim, a utilização dos EPI's por parte dos colaboradores é um ponto que deve ser sempre relembrado, a fim de garantir a segurança e integridade física desses, e preveni-los das doenças ocupacionais. Palestras de conscientização são importantes a fim de alertá-los acerca dos riscos que a falta de segurança pode proporcionar. Os responsáveis pela obra, podem ainda estabelecer um sistema de "penas" (como o pagamento de uma taxa por parte do colaborador) para aqueles que não estiverem fazendo uso dos equipamentos.

\section{Considerações Finais}

Diante do exposto, conclui-se que a indústria da construção civil é um dos setores que causam mais impactos ao meio ambiente. Devido a magnitude desses, há um crescimento na busca pela construção sustentável, visando estabelecer estratégias capazes de minorar os problemas ambientais.

Uma solução viável para minimizar os impactos produzidos pelas obras em questão é optar por seguir os princípios da Construção Enxuta. Para isso, se faz necessário adotar algumas medidas como, organizar o canteiro de obra de modo a reduzir a perda de material e a geração de resíduos sólidos; adequar a construção de acordo com os limites impostos pelo meio ambiente; reutilizar os materiais que aparentemente não teriam mais utilidade e fazer um correto descarte dos resíduos.

Assim, a adoção de uma gestão baseada nos princípios da Construção Enxuta visa otimizar o tempo de execução da obra, reduzir os desperdícios e o custo final da construção, proporcionando aumento do lucro e a preservação do meio ambiente. 


\section{REFERÊNCIAS}

BRASIL. Conselho Nacional de Meio Ambiente. (2002) Resolução CONAMA no. 307, de 5 de julho de 2002. Estabelece diretrizes, critérios e procedimentos para a gestão de resíduos da construção civil. Ministério do Meio Ambiente: CONAMA, 2002. Diário Oficial da União. Brasília, DF: Imprensa Oficial.

DEPARTAMENTO INTERSINDICAL DE ESTATÍSTICA E ESTUDOS SOCIOECONÔMICOS (DIEESE). Estudo Setorial da Construção, 2020.

FERREIRA, D. C. et at. Degradação ambiental ocasionada pela construção Civil no município de Natal/RN: Estudo de caso de vila de ponta Negra. In: Encontro Nacional de Engenharia de Produção: A integração de cadeias produtivas com a abordagem da manufatura sustentável, 28.,2008, Rio de Janeiro. Artigo... Rio de Janeiro: Windsor Barra, 2008, p.1-9.

FORMOSO, C. T. Lean Constructruction: princípios básicos e exemplos. In Construção Mercado: custos, suprimentos, planejamento e controle de obras. Porto Alegre, v. 15, p. 50-58, 2002.

JOHN, V. M. Reciclagem de resíduos na construção civil: Contribuição à metodologia de pesquisa e desenvolvimento., 2000, 102f. Tese de livre docência - Escola Politécnica, Universidade de São Paulo, São Paulo.

KOSKELA, L. Application of the new production philosophy to construction. CIFE Technical Report. Stanford University, Palo Alto, California, 1992p. 50-58, 1992.

PICCHI, F. A. Oportunidades da aplicação do Lean Thinking na construção. Revista Ambiente Construído, Porto Alegre, Volume 03, №. 01, p. 7-23, 2003.

PINTO, T. P. (Coord.) Gestão Ambiental de resíduos da construção civil: A experiência do Sinduscon-SP. São Paulo: Obra Limpa: I\&T: Sinduscon-SP, 2005.

REIS, C. C. C. et al. Construção enxuta, análise e levantamento de sugestões em um canteiro de obra de ampliação residencial. In: Congresso Brasileiro de Engenharia de Produção, 5.,2015, Ponta Grossa. Artigo... Ponta Grossa, 2015, p. 1-12.

SILVA, C. R. O. S. Metodologia e organização do projeto de pesquisa. Centro Federal de Educação Tecnologia do Ceará, Guia Prático, Fortaleza, 2004.

VIEIRA, V. A. As tipologias, variações e características da pesquisa de marketing. Curitiba: Rev. FAE, Curitiba, 5(1), p. 61-70, 2002. 


\title{
O USO DA SIMULAÇÃO NO PROCESSO DE TOMADA DE DECISÃO EM UMA EMPRESA DO SETOR VAREJISTA
}

\author{
lochane Garcia Guimarãe \\ Universidade Federal de Santa Maria - UFSM \\ Leonardo Marques Caires \\ Universidade Federal de Santa Catarina - UFSC \\ Virginia Thomasi \\ Universidade Federal de Santa Maria - UFSM
}

\section{RESUMO}

Este trabalho foi desenvolvido em uma grande empresa do setor varejista brasileiro, que possui sistema de serviço baseado no autoatendimento. Este sistema tem como premissa uma área de vendas bem estruturada, em que o cliente seja capaz de escolher os próprios produtos, com colaboradores atentos e disponíveis para atendimento personalizado caso o cliente solicite. Ou seja, a maioria dos clientes entra na loja, realiza suas compras e sai tendo contato apenas com um colaborador, o caixa que realizou a operação de pagamento. Este ponto foi fundamental para a escolha do processo que será analisado e simulado detalhadamente neste trabalho: as filas de caixas. Assim, o objetivo deste estudo é demonstrar a utilidade e o potencial da simulação computacional para auxiliar o processo de tomada de decisão em sistemas de filas de caixas, a fim de contribuir para minimização das filas formadas, promover maior equilíbrio na utilização dos atendentes e permitir melhorias no nível de serviço oferecido ao cliente. 0 estudo demostrou qual o sistema de disposição dos caixas fornece mais vantagens para o cliente e para a empresa, refletindo na diminuição do tempo de espera no sistema, pois reduz a ociosidade do operador.

\section{Palavras-chave:}

Caixas de atendimento; Simulação; Teoria das filas.

\section{ABSTRACT}

This work was developed in a large company in the Brazilian retail sector, which has a service system based on self-service. This system is based on a wellstructured sales area, in which the customer is able to choose their own products, with attentive employees and available for personalized service if the customer requests it. That is, most customers enter the store, make their purchases and leave having contact only with one employee, the cashier who performed the payment operation. This point was fundamental for the choice of the process that will be analyzed and simulated in detail in this work: the rows of boxes. Thus, the objective of this study is to demonstrate the utility and potential of computer simulation to assist the decision-making process in cashier queuing systems, in order to contribute to minimizing the queues formed, promoting greater balance in the use of attendants and allowing improvements in the level of service offered to the customer. The study showed which cashier disposal system provides the most advantages for the customer and the company, reflecting the reduction in waiting time in the system, as it reduces operator idle time.

\section{Keywords:}

Call boxes. Simulation. Queuing theory. 
INTRODUÇÃO

O crescimento da concorrência e as alterações de comportamento e hábitos dos consumidores têm sido fundamentais na promoção das significativas mudanças no comércio varejista. A concorrência, crescente entre lojas de mesmo formato e entre diferentes tipos de lojas, tem levado as empresas à necessidade de implantar programas de redução de custos, de racionalização das operações e de diferenciação de serviços para atrair mais consumidores (SANTOS; GIMENEZ, 2002). Em um setor competitivo, processos estruturados e eficientes garantem ganho para o negócio, através do aumento de produtividade dos operadores. Análises que possam medir ociosidade e simular situações extremas de atendimento são fundamentais para garantir o nível de serviço desejado.

As filas, além de não serem agradáveis aos consumidores, do ponto de vista das empresas, podem representar um grande problema com a perda de negócios. Usualmente, a modelagem de sistemas pode ser feita por duas abordagens inteiramente diferentes entre si, a Teoria das Filas e a simulação, sendo esta última mais utilizada e caracterizada por ser uma técnica que permite representar o funcionamento de um sistema real com maior exatidão (PRADO, 2004).

A Teoria das Filas é uma ferramenta que permite analisar e dimensionar sistemas para evitar desperdícios e eliminar gargalos de operação. No varejo, esta teoria visa a obter um modelo de previsão do comportamento da demanda, para estabelecer parâmetros que mantenham a estabilidade do sistema, garantindo à gerência que não haverá situações de descontrole que evidenciem incapacidade da loja em atender os consumidores. Assim, uma fila controlada torna-se um fator de competitividade, podendo impactar diretamente no resultado financeiro e operacional da organização (GUIMARAES et al., 2014).

Segundo Muniz, Guimarães e Campos (2009), a simulação oferece diversas vantagens que justificam sua utilização. Uma vez criado e validado o modelo, este pode ser utilizado inúmeras vezes para a análise de outros projetos e novas políticas. Guimares et al. (2014) acrescenta que, com a utilização de modelos computacionais, é possível ter uma melhor visão das operações no processo, visto que dentro do sistema alguns detalhes importantes podem passar despercebidos.

Este estudo foi desenvolvido em uma grande empresa do setor varejista brasileiro, que possui um sistema de serviço baseado no autoatendimento. O sistema tem como premissa a área de vendas bem estruturada, onde o cliente seja capaz de escolher os próprios produtos, com colaboradores atentos e disponíveis para atendimento personalizado caso o cliente solicite. Ou seja, nesse processo a maioria dos clientes entra na loja, realiza suas compras e sai tendo contato apenas com um colaborador, o caixa que realizou a operação de pagamento. Este ponto foi fundamental para a escolha do processo que será analisado e simulado detalhadamente neste trabalho: as filas de caixas.

Assim, o objetivo desta pesquisa é demonstrar a utilidade e o potencial da simulação computacional para auxiliar o processo de tomada de decisão em sistemas de filas de caixas, a fim de contribuir para minimização das filas formadas, promover maior equilíbrio na utilização dos atendentes e permitir uma melhora no nível de serviço oferecido ao cliente. 


\section{REVISÃO BIBLIOGRÁFICA}

A simulação consiste em um processo de experimentação, com um modelo detalhado de um sistema real para determinar como o sistema responderá a mudanças em sua estrutura, ambiente ou condições de contorno (ANZANELLO, 2013). Para expandir a capacidade de uma simulação, combina-se a esta, ferramentas específicas que façam um estudo adicional das informações adquiridas, demonstrando de forma mais clara e precisa o comportamento do novo sistema com o objetivo de um tratamento mais amplo dos dados, fornecendo uma perspectiva mais próxima do real (MENEZES et al., 2001).

Alexandre (2010) acrescenta que permite imitar um procedimento real em menor tempo e com menor custo, permitindo um melhor estudo do que acontecerá com a possibilidade de alterações e como consertar erros que gerariam grandes gastos. A simulação pode ser dividida em dois tipos: simulação discreta - utilizada em sistemas onde a mudança de estado se dá de forma descontínua, eventos que indicam o início e o fim das operações; e simulação contínua - utilizada em sistemas cujas variáveis mudam continuamente de valor (por exemplo, equações diferenciais).

Neste contexto, de acordo com Miyagi (2006) o comportamento de um sistema pode ser estudado através de um modelo de simulação, no qual geralmente utiliza diversos parâmetros sobre a operação do sistema. Uma vez desenvolvido e validado, o modelo pode ser usado para investigar uma grande variedade de questões sobre o sistema, e mudanças podem ser simuladas a fim de prever seu impacto no seu desempenho. A simulação ainda pode ser usada para estudar sistemas na fase de concepção, antes que sejam efetivamente implementados. A Figura 1 apresenta o procedimento para uma análise de sistemas por simulação conforme Miyagi (2006).

Figura 1- Procedimento para análise de sistemas por simulação

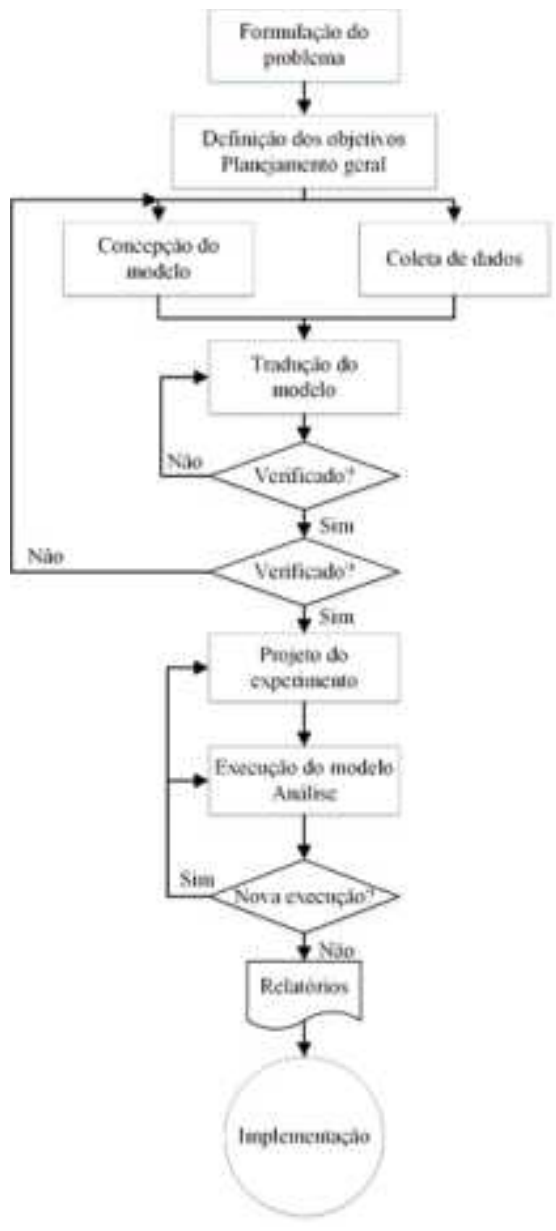

Fonte: Miyagi (2006). 
Ainda neste sentido, Miyagi (2006) salienta que um sistema de filas é caracterizado por uma população de elementos que deseja um serviço, pela natureza das chegadas dos elementos para execução dos serviços, pela natureza dos serviços a serem realizados, pela capacidade do sistema e pela disciplina de fila. A Figura 2 apresenta um sistema discreto de filas conforme Miyagi (2006).

Figura 2 - Ilustração de um sistema discreto de filas

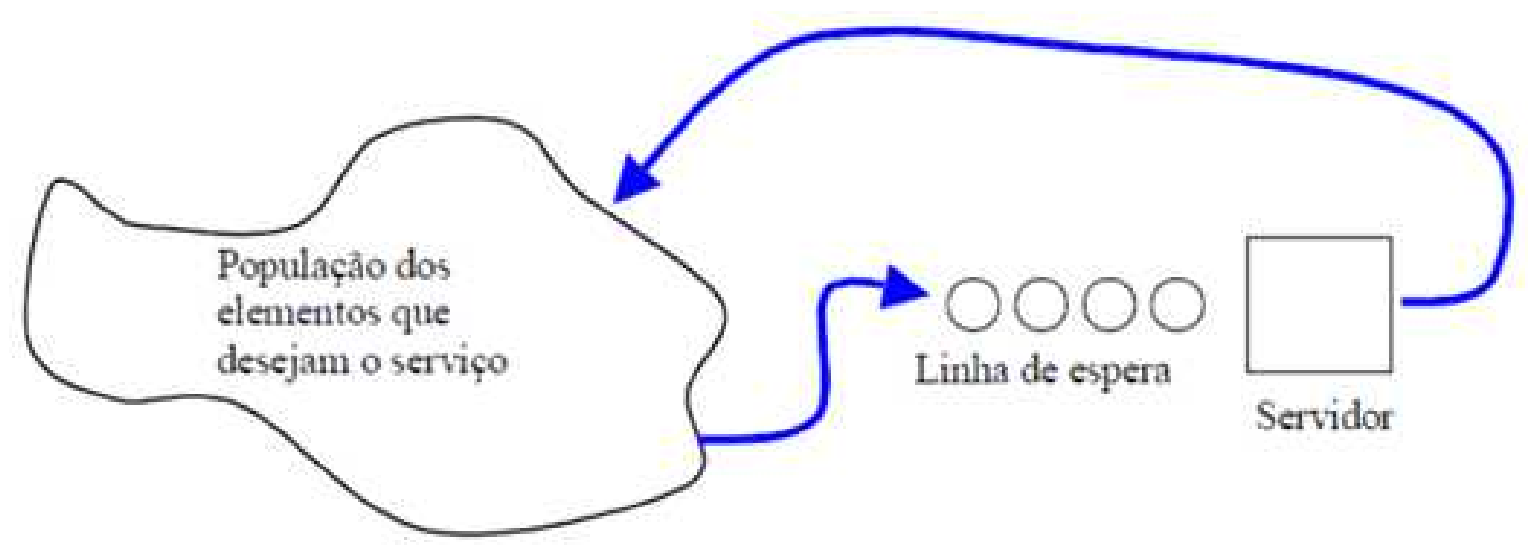

Fonte: Miyagi (2006).

Este sistema de filas considera que a população é infinita, isto é, se um elemento desta população for para a fila de espera do serviço, não existe alteração na taxa de chegada de outros elementos que estejam precisando deste serviço. O tempo de serviço é definido de acordo com uma distribuição de probabilidades que é considerada constante. A capacidade do sistema é considerada infinita (o sistema inclui o elemento que está no servidor mais aqueles que estão esperando na fila). Os elementos são atendidos pelo servidor na ordem de chegada, procedimento conhecido como FIFO (first in, first out) (MIYAGI, 2006).

Hillier e Lieberman (2013) explicam que os sistemas de fila, logo após começarem a operar, se encontram em condição transiente (não estacionário), devido a sofrer um grande impacto da situação inicial do sistema e o tempo decorrido, entretanto conforme passa o tempo o sistema atinge o estado estacionário, facilitando assim a modelagem do problema. Ou seja, o comportamento dos dados se repete com um mesmo padrão ao longo do tempo permitindo a análise do cenário (ANDRADE, 2009).

Para Arenales (2007), os resultados da análise de sistemas de filas podem ser usados em modelos de otimização, por exemplo, minimizando a soma dos custos de oferecer um nível de serviço no sistema e a soma dos custos dos atrasos ou perdas de usuários. Enquanto os custos operacionais de oferecer o serviço aumentam com o aumento do nível de serviço, os custos devido aos atrasos sofridos pelos usuários diminuem.

\section{METODOLOGIA}

No presente trabalho foram feitas simulações utilizando o modelo de um único servidor. Foi escolhido este modelo, pois os dados utilizados para os cálculos são de média de atendimento por loja, ou seja, de toda a equipe, e não por caixa. O objetivo principal foi encontrar o modelo com menor ociosidade 
dos colaboradores que ocupam a posição de caixas, além de propor modelos que não ultrapassassem 3 pessoas no sistema de atendimento por caixa, ou nenhuma fila. Todos os cálculos foram desenvolvidos no excel, utilizando as fórmulas propostas pelo modelo.

\section{ESTUDO DE CASO}

A empresa na qual este trabalho foi desenvolvido está entre as 10 maiores varejistas do Brasil, segundo o ranking do Ibevar, e é a segunda maior loja de departamentos do país. A rede é composta por lojas especializadas em moda orientada a estilos de vida. É uma empresa de capital aberto desde 1967, e em 2005 entrou no Novo Mercado da Bovespa, passando a ter $100 \%$ das ações em circulação. A empresa conta hoje com 217 lojas, 15 mil colaboradorese faturamento em torno de 3,5 bilhões por ano.

Os primeiros layouts de loja desta empresa tinham estilo "parede" de caixas, ou seja, ao fundo da loja junto à parede os caixas ficavam localizados e os clientes aguardavam atendimento em fila única. Os modelos seguintes foram planejados no estilo "ilhas", com uma ilha central com atendimento em bilateral ou 2 ilhas com atendimento unilateral. Estes dois modelos são matematicamente equivalentes. Os layouts que atualmente estão sendo utilizados nas novas lojas da empresa analisada seguem um estilo multifunção, em que os operadores não são mais segmentados em caixas e vendedores. Neste modelo, os pontos de venda são individuais e espalhados dentro da loja, sem operador fixo. Os colaboradores ocupam a área de vendas, fazem outras atividades e operam caixas quando surgem clientes, diminuindo a ociosidade.

O problema surgiu quando algumas concorrentes, bastante conhecidas no mercado por desenvolverem estudos de produtividade, inauguraram novas lojas no modelo antigo, estilo "parede". Os representantes da empresa questionaram então os modelos mais novos, se os mesmos eram realmente mais vantajosos. Por este motivo, o presente trabalho busca explorar os diferentes tipos de layouts para diferentes demandas.

Os modelos trabalhados serão o modelo de "parede" de caixas (modelo M1), o modelo de ilha dupla de caixas (modelo M2) e o modelo multitarefa (modelo M3). Vale ressaltar, que o modelo M3 consiste no modelo que está sendo utilizado em cerca de $9 \%$ das lojas da empresa analisada.

Foram simulados cenários com diferentes números de caixas propondo sempre comparações entre os layouts M1/M2 e M3, considerando sempre as diferentes demandas previstas de transações. Ao todo, foram desenvolvidos estudos que correspondem a 8 faixas de metas para situações de uso de até 12 caixas, o que totalizou 96 simulações. Os dados utilizados para desenvolver as simulações estão relacionados na Tabela 1.

Utilizando dados experimentais apresentados na Tabela 1, verificou-se que um caixa leva, em média, 1,4 minutos para realizar uma operação, e que os tempos estimados de caminhadas entre a atividade de venda e de caixa para o modelo M3 é de 2 minutos. Para os modelos M1 e M2 considerou-se uma taxa de serviço de 0,95 , e para o modelo $M 3$ foi considerada uma taxa de serviço de 0,85 , pois acredita-se que neste modelo gasta-se mais tempo para substituir vendedores e para realizar login no sistema. Ao total, são 17 pessoas envolvidas nas tarefas de vendas e de operação de caixa. No desenvolvimento deste estudo pode-se concluir que o layout do tipo M3 é mais rentável em relação aos modelos antigamente utilizados (modelos M1/M2), para o médio-longo prazo em qualquer uma das faixas de metas avaliadas. 
Tabela 1 - Dados utilizados para desenvolver as simulações

\begin{tabular}{|c|c|c|c|c|c|c|c|}
\hline \multirow{3}{*}{ Tipo } & \multirow{3}{*}{$\begin{array}{l}\text { Metas estabele - } \\
\text { cidas para lojas } \\
\text { do tipo "P" }\end{array}$} & \multicolumn{3}{|l|}{ ados do problema } & \multirow[t]{2}{*}{$\begin{array}{l}\text { Tempo de uma } \\
\text { transação: } 1,25 \\
\text { min. }\end{array}$} & \multirow{3}{*}{$\begin{array}{l}\text { transações } \\
\text { por hora: } \\
\text { 60/NT } \\
\mathrm{N}^{0} \text { médio de } \\
\text { operações } \\
\text { que um } \\
\text { caixa faz } \\
\text { por hora } \\
\text { (unidades) }\end{array}$} & \multirow{3}{*}{$\begin{array}{c}\text { Estimativa } \\
\text { Tempos estima - } \\
\text { dos de caminha } \\
\text { das entre a ativi } \\
\text { dade de venda e } \\
\text { de caixa (M3) por } \\
\text { trasação (minutos) }\end{array}$} \\
\hline & & \multirow{2}{*}{$\begin{array}{c}\mathrm{N}^{\mathrm{o}} \text { médio de } \\
\text { transações } \\
\text { (trasações/dia) }\end{array}$} & \multicolumn{2}{|c|}{$\begin{array}{c}\mathrm{N}^{\circ} \text { de transações após as } \\
17 \mathrm{~h}\end{array}$} & & & \\
\hline & & & $\begin{array}{l}\text { Média por } \\
\text { hora }(\lambda)\end{array}$ & $\begin{array}{l}\text { Todas das } \\
17 \text { as } 22 \mathrm{~h} \text {. }\end{array}$ & $\begin{array}{l}\text { Tempo médio } \\
\text { que } 1 \text { caixa leva } \\
\text { para fazer uma } \\
\text { transação }\end{array}$ & & \\
\hline 1 & 15.000 & 242 & 23 & 114 & 1,4 & 42,9 & 2,00 \\
\hline 2 & 20.000 & 323 & 30 & 151 & 1,4 & 42,9 & 2,00 \\
\hline 3 & 25.000 & 403 & 38 & 189 & 1,4 & 42,9 & 2,00 \\
\hline 4 & 30.000 & 484 & 45 & 227 & 1,4 & 42,9 & 2,00 \\
\hline 5 & 35.000 & 565 & 53 & 265 & 1,4 & 42,9 & 2,00 \\
\hline 6 & 40.000 & 645 & 61 & 303 & 1,4 & 42,9 & 2,00 \\
\hline 7 & 45.000 & 726 & 68 & 341 & 1,4 & 42,9 & 2,00 \\
\hline 8 & 50.000 & 806 & 76 & 379 & 1,4 & 42,9 & 2,00 \\
\hline
\end{tabular}

Fonte: Autores.

E isso é facilmente percebido pois em todas as 96 simulações há valores significativamente inferiores para os dados de "ociosidade da equipe", enquanto que o dado de "Número médio de clientes no sistema de atendimento por caixa" praticamente permanece inalterado. Isto pode ser verificado no cálculo feito para 5 caixas, ilustrado na Tabela 2.

Tabela 2 - Simulação de número de clientes no sistema e ociosidade da equipe para 5 caixas para os modelos M1/M2 e M3

\begin{tabular}{c|cc|cc}
\hline \multirow{2}{*}{ Metas } & \multicolumn{3}{c}{ Layout M1/M2 } & \multicolumn{2}{c}{ Layout M3 } \\
\cline { 2 - 5 } & $\begin{array}{c}\text { Ociosidade da } \\
\text { equipe }\end{array}$ & $\begin{array}{c}\text { Número médio de clientes } \\
\text { no sistema de } \\
\text { atendimento por caixa }\end{array}$ & $\begin{array}{c}\text { Ociosidade da } \\
\text { equipe }\end{array}$ & $\begin{array}{c}\text { Número médio de clientes } \\
\text { no sistema de atendimento } \\
\text { por caixa }\end{array}$ \\
\hline 15000 & $26 \%$ & 0,06 & $0,26 \%$ & 0,09 \\
20000 & $25 \%$ & 0,08 & $0,35 \%$ & 0,13 \\
25000 & $24 \%$ & 0,11 & $0,42 \%$ & 0,18 \\
30000 & $23 \%$ & 0,15 & $0,42 \%$ & 0,24 \\
35000 & $22 \%$ & 0,19 & $0,42 \%$ & 0,31 \\
40000 & $21 \%$ & 0,25 & $0,42 \%$ & 0,41 \\
45000 & $20 \%$ & 0,32 & $0,42 \%$ & 0,55 \\
50000 & $18 \%$ & 0,41 & $0,42 \%$ & 0,75 \\
\hline
\end{tabular}

Fonte: Autores. 
Ressalta-se, porém, a importância de complementar os dados deste estudo com informações de aceitação do mercado junto a outros setores da empresa. Com estes dados de apoio, pode-se avaliar melhor a real viabilidade para a implementação deste modelo em toda a rede. No Quadro 1 são relacionadas as principais vantagens e desvantagens para os dois modelos de layout de loja (M1/M2 e M3).

Quadro 1 - Vantagens e Desvantagens para cada tipo de layout de loja

\begin{tabular}{|c|c|c|}
\hline Layout & PRÓS & CONTRAS \\
\hline \multirow{3}{*}{$\begin{array}{l}\text { M1/M2 } \\
\text { (operadores } \\
\text { de caixas } \\
\text { fixos) }\end{array}$} & $\begin{array}{l}\text { Condição de trabalho já conhecida e em } \\
\text { operação nas lojas; }\end{array}$ & $\begin{array}{l}\text { Elevados índices de ociosidades dos operadores } \\
\text { dos caixas e, consequentemente da equipe; }\end{array}$ \\
\hline & $\begin{array}{l}\text { Custo inicial de operação mais baixos, pois } \\
\text { o método não exige treinamento } \\
\text { diferenciado; }\end{array}$ & \multirow{2}{*}{$\begin{array}{l}\text { Tendência a haver custo maior na mão -de-obra } \\
\text { de chão de loja no médio -longo prazo em função } \\
\text { da menor eficiência da equipe. }\end{array}$} \\
\hline & $\begin{array}{l}\text { Menor investimento inicial em número de } \\
\text { equipamento (estrutura fixa). }\end{array}$ & \\
\hline \multirow{4}{*}{$\begin{array}{c}\text { M3 } \\
\text { (operadores } \\
\text { de caixas que } \\
\text { possuem a } \\
\text { função de } \\
\text { atendentes } \\
\text { também) }\end{array}$} & $\begin{array}{l}\text { Insignificantes índices de ociosidades dos } \\
\text { colaboradores; }\end{array}$ & $\begin{array}{l}\text { Condição de trabalho nova e com prática ainda } \\
\text { desconhecida; }\end{array}$ \\
\hline & $\begin{array}{l}\text { Tendência a haver custo menor na mão -de- } \\
\text { obra de chão de loja no médio-longo prazo } \\
\text { em função da maior eficiência da equipe; }\end{array}$ & $\begin{array}{l}\text { Envolve custo inicial de operação mais alto do } \\
\text { que em M1/M2, visto que há necessidade de } \\
\text { adaptação em um novo padrão de trabalho; }\end{array}$ \\
\hline & \multirow{2}{*}{$\begin{array}{l}\text { Trabalho mais igualitário entre os } \\
\text { componentes da equipe. }\end{array}$} & $\begin{array}{l}\text { Necessidade de planejamento de novos padrões } \\
\text { de treinamento da equipe envolvida; }\end{array}$ \\
\hline & & $\begin{array}{l}\text { Investimento inicial em maior número de } \\
\text { equipamentos (estrutura fixa). }\end{array}$ \\
\hline
\end{tabular}

Fonte: Autores.

Inicialmente sugeriu-se colocar até 12 pontos de caixas espalhados na loja para atendimento simultâneo. Entretanto, avaliando as ociosidades e números médios de atendimento simultâneos por caixa, chegou-se a conclusão que este número estava acima das reais necessidades calculadas. 0 fato está exemplificado na Tabela 3.

Tabela 3 - Simulações com diferentes números de caixas para o modelo M3

\begin{tabular}{cccc}
\hline \multicolumn{4}{c}{ Simulação Sugerida } \\
\hline Metas & $\begin{array}{c}\text { Número de } \\
\text { caixas }\end{array}$ & $\begin{array}{c}\text { Número médio de clientes no sistema } \\
\text { de atendimento por caixa (pessoas) }\end{array}$ & $\begin{array}{c}\text { Ociosidade estimada } \\
\text { da equipe (\%) }\end{array}$ \\
\hline 15000 & 3 & 0,09 & 0,25 \\
20000 & 3 & 0,13 & 0,25 \\
25000 & 3 & 0,18 & 0,25 \\
30000 & 4 & 0,11 & 0,34 \\
35000 & 4 & 0,14 & 0,34 \\
40000 & 4 & 0,18 & 0,34 \\
45000 & 5 & 0,12 & 0,42 \\
50000 & 5 & 0,14 & 0,42 \\
\hline
\end{tabular}

Fonte: Autores. 
Percebe-se que o número médio de clientes no sistema de atendimento por caixa é menor que $0,2,0$ que garante folga nos pontos de caixas. O sistema também garante folga para picos de demanda de pelo menos cinco vezes o volume de transações médias calculadas. Para as datas comemorativas, que historicamente apresentam picos de demanda bem elevados, sugere -se o uso de um ponto de caixa adicional como fator de segurança para cada faixa de metas. O número médio de clientes no sistema de atendimento por caixa e a ociosidade da equipe para esta situação estão colocados na Tabela 4.

Tabela 4 - Situação sugerida com um ponto de caixa extra

\begin{tabular}{cccc}
\hline Metas & Número de caixas & $\begin{array}{c}\text { Número médio de clientes } \\
\text { no sistema de atendimento } \\
\text { por caixa (pessoas) }\end{array}$ & $\begin{array}{c}\text { Ociosidade estimada da } \\
\text { equipe (\%) }\end{array}$ \\
\hline 15000 & 4 & 0,05 & 0,26 \\
20000 & 4 & 0,07 & 0,34 \\
25000 & 4 & 0,09 & 0,34 \\
30000 & 5 & 0,07 & 0,42 \\
35000 & 5 & 0,08 & 0,42 \\
40000 & 5 & 0,10 & 0,42 \\
45000 & 6 & 0,08 & 0,50 \\
50000 & 6 & 0,09 & 0,50 \\
\hline
\end{tabular}

Fonte: Autores.

Percebe-se que, para lojas com faixas de metas de até $R \$ 25.000,00$, é recomendada a utilização de 4 pontos de caixas. Já para lojas com metas entre $\mathrm{R} \$ 25.000,00$ e $\mathrm{R} \$ 40.000,00$ seriam necessários 5 pontos de caixas. E, para lojas com metas de vendas acima de $\mathrm{R} \$ 40.000,00$, recomenda-se a colocação de 6 pontos de caixas.

\section{CONSIDERAÇÕES FINAIS}

O estudo mostrou que os sistemas antigos de layout (M1 e M2) não apresentam nenhuma vantagem em relação ao M3. Conclui-se que o sistema de disposição dos caixas que estão sendo utilizados atualmente, por uma parcela menor de lojas, é mais vantajoso para o cliente, pois diminuem o tempo de espera no sistema, e também para a empresa, pois reduz a ociosidade do operador. Este resultado aponta dois diferenciais competitivos de M3: maior produtividade e melhor nível de serviço.

O novo layout surgiu há menos de 2 anos, e acreditava-se que era vantajoso apenas para empresas com faturamentos anuais abaixo de 12 milhões. Este trabalho quebra esta limitação de faturamento e mostra que para qualquer faixa de demanda (simulada conforme meta/dia), o M3 é mais rentável.

Para estudos futuros, é possível medir o ganho em implantar M3 em todas as lojas, e qual seria o tempo de retorno do investimento. Outra questão ainda não mensurada é o período de adaptação do colaborador multifunção. É possível, por exemplo, que com mais responsabilidades, o colaborador se sinta mais engajado no trabalho. Este trabalho foi de extrema importância para resolver um problema recente da empresa e abriu caminhos para que novos estudos sejam conduzidos. 


\section{REFERÊNCIAS}

ALEXANDRE, R. F. Modelagem, simulação da operação e otimização multiobjetivo aplicada ao problema de despacho de veículos em minas a céu aberto. Universidade Federal de Minas Gerais, Belo Horizonte, 2010. (Dissertação de Mestrado).

ANZANELLO, M. Simulação da Produção. Porto Alegre: Apostila de pós-graduação em Engenharia de Produção, 2013.

ANDRADE, E. L. Introdução à Pesquisa Operacional - Métodos e Modelos para Análise de Decisões. 4ạ edição. Rio de Janeiro: LTC, 2009.

ARENALES, M.; ARMENTANO, V.; MORABITO, R.; YANASSE, H. Pesquisa Operacional para cursos de engenharia. 5a ed. Rio de Janeiro: Elsevier, 2007.

GUIMARAES, J. M. V; PONTES, H. L. J.; PAULINO, G. P.; ALBERTIN, M. R. Melhoria no atendimento dos caixas numa empresa varejista utilizando teoria das filas: um estudo de caso. XXXIV Encontro Nacional de Engenharia de Produção. Anais...Curitiba, PR: 2014.

HILLIER, F. S.; LIEBERMAN, G. J. Introdução à Pesquisa Operacional, 9ạ edição. Porto Alegre: AMGH, 2012.

MIYAGI, P. E. Introdução à simulação discreta. Apostila de aula, USP, 2006.

MENEZES, R. P. B.; MUNIZ, P. H. P.; NETO, A. R. B.; LEPIKSON, H. A. Modelagem de sistemas integrados de manufatura por simulação dinâmica discreta. In: Encontro Nacional de Engenharia de Produção Salvador: Anais do ENEGEP, 2001.

MUNIZ, L. R.; GUIMARÃES, I. F. G.; CAMPOS, M. S. Aplicação da simulação computacional para análise do tráfego no cruzamento central da cidade histórica de Mariana - MG. In: XXIX Encontro Nacional de Engenharia de Produção. 2009. Salvador: Anais... Salvador, 2009.

PRADO, D. Teoria das Filas e da Simulação. 2a edição. Belo Horizonte: INDG TecS, 2004.125 p.

SANTOS, A.; GIMENEZ, L. C. P. Reestruturação do comércio varejista e de supermercados. BNDE. Disponível em: www.cartaobndes.com/conhecimento/bnset/set903. Acessado em 20/09/2015. v. 22, 2002 


\title{
GESTÃO DE PROCESSOS NO SETOR PÚBLICO: \\ UM ESTUDO NA UNIVERSIDADE FEDERAL DO TOCANTINS
}

\author{
Jordana Teixeira de Melo Dias \\ Universidade Federal do Tocantins \\ jordanamelo492@hotmail.com \\ Helga Midori Iwamoto \\ Universidade Federal do Tocantins \\ helga.iwamoto@gmail.com
}

\begin{abstract}
RESUMO
Embora haja poucos relatos na literatura, nos últimos anos o foco em melhorias de processos vem se popularizando no setor público, e isto inclui o ambiente de ensino superior. É possível que as universidades debatam, com base em princípios e conceitos de qualidade, sobre as perspectivas de aprimorar seus processos. Nesse sentido, o objetivo deste artigo é avaliar em que medida as iniciativas de gerenciamento de processos da Universidade Federal do Tocantins (UFT), por meio dos fundamentos do Business Process Management (BPM) precisam ser melhoradas a partir da análise de 2 (dois) critérios (Pessoas e Processos) do Instrumento de Autoavaliação da Gestão do Extinto GesPública na percepção de gestores. Na fase de coleta de dados foi aplicada uma entrevista semiestruturada. Para a apreciação das informações foi realizada análise
\end{abstract}

de conteúdo com triangulação de dados a fim de compreender os significados das falas dos gestores. Os resultados mostram que estes na atual estrutura administrativa estão à procura de melhorias nos processos que competem à sua gestão. No entanto, será um grande desafio para os gestores da UFT fortalecer os pontos positivos, bem como ajustar as dificuldades, os pontos negativos, que podem impedir as etapas do BPM se realizarem com sucesso.

\section{Palavras-chave:}

Processos; Gestão de Processos; Setor Público; GestPública; Universidade.

\begin{abstract}
Although there are few reports in the literature, in recent years the focus on process improvements has become popular in the public sector, and this includes the higher education environment. It is possible that universities debate, based on principles and quality concepts, on the prospects of improving their processes. In this sense, the objective of this article is to evaluate to what extent the process management initiatives of the Federal University of Tocantins (UFT) through the fundamentals of Business Process Management (BPM) need to be improved by analyzing two (2) criteria (People and Processes) of the SelfAssessment Tool of the Management of the Extinct GesPública in the perception of managers. In the data collection phase, a semi-structured interview was
\end{abstract}

applied. In order to evaluate the information, content analysis was performed with data triangulation to understand the meanings of the managers' speeches. The results show that these in the current administrative structure are looking for improvements in the processes that compete for their management. However, it will be a great challenge for UFT managers to strengthen the positive points, as well as to adjust the difficulties, negative points, that can prevent successful BPM steps.

\section{Keywords:}

Processes; Processes management; Public sector; GesPública; University. 


\section{INTRODUÇÃO}

Em função de poucos estudos na literatura acadêmica sobre melhorias em processos no ambiente público, surgiram necessidades de estabelecer práticas nas organizações públicas (BECKER; ALGERMISSEN; NIEHAVES; 2006), como o uso de ferramentas gerenciais da iniciativa privada, em especial o BPM. Esta abordagem foi criada para gerir e melhorar os processos organizacionais, tanto no setor privado quanto no setor público (NIEHAVES, 2010). Leva-se em consideração que o uso de técnicas e ferramentas do setor privado para o setor público requer adaptação destas (ŠTEMBERGER; KOVACIC; JAKLIČ, 2007).

A abordagem de gestão por processos, no âmbito do setor público, ganhou espaço com a criação de programas de prêmios de qualidade. No Brasil, por volta da década de 1990, houve a introdução do conceito de qualidade total e reengenharia, fundamentando-se nos critérios do Prêmio Fundação Nacional da Qualidade. O último programa relacionado foi o Programa Nacional de Gestão Pública e Desburocratização (GesPública) conhecido por ser uma política pública voltada para a modernização do Estado, com ênfase no cidadão.

Diante o exposto, o objetivo deste artigo é avaliar em que medida as iniciativas de gerenciamento de processos da Universidade Federal do Tocantins precisam ser melhoradas. Este exame foi possível a partir da análise de 2 (dois) critérios (Pessoas e Processos) do Instrumento de Autoavaliação da Gestão do Extinto GesPública pela percepção de gestores (Pró-Reitores e diretores).

Este estudo se justifica por contribuir com o rol de pesquisas sobre Gestão de Processos em Organizações Públicas, em particular em universidades públicas como a UFT que está inserida espacialmente em um território com riquezas naturais, variedade cultural e oportunidades, como o Tocantins. Complementando esta análise, o Relatório de Gestão do exercício de 2016 constata que:

\section{[...] a Universidade Federal do Tocantins vem se estruturando para fortalecer a sua área do planejamento e gestão [...] valendo se de um modelo de planejamento que conta principalmente com o Planejamento Estratégico (PE)/2014 - 2022 e o Plano de Desenvolvimento Institucional (PDI) / 2016 - 2020. Tais instrumentos contribuem para um melhor alcance da sua missão, visão de futuro, valores e objetivos estratégicos para o ensino superior do estado do Tocantins e do Brasil (UFT, 2017a, p. 8,)}

Percebe-se que entender e compreender a atuação da UFT nessa temática da pesquisa poderá colaborar com o desenvolvimento regional em que está inserida, no que tange a inovação e qualidade na gestão.

O trabalho está organizado em 5(cinco) seções, incluindo esta Introdução. O capítulo 2 apresenta uma revisão da literatura sobre a Gestão de Processos no Setor Público o qual serviu de base para 
tratarmos dos resultados da pesquisa empírica. O capítulo 3 apresenta a metodologia da pesquisa e traça o percurso metodológico proposto. 0 capítulo 4 apresenta e discute os resultados. Por fim, o capítulo 5 apresenta as conclusões e limitações da pesquisa. Na próxima seção é verificado como a literatura expõe os debates teóricos sobre a temática estudada.

\section{GESTÃO DE PROCESSOS NO SETOR PÚBLICO: BREVES DEBATES TEÓRICOS SOBRE PROCESSOS, PESSOAS E MELHORIA DA QUALIDADE NOS SERVIÇOS PÚBLICOS}

Apesar da popularização da Gestão de Processos no setor público nos últimos anos há poucos relatos na literatura sobre o tema (RADNOR; O'MAHONEY, 2013; MCADAM; DONAGHY, 1999; GULLEDGE JR; SOMMER, 2002; BIAZZI; MUSCAT; BIAZZI, 2011).

Ao longo dos anos tem havido uma transformação pela busca por desempenho nos resultados na administração pública da maioria dos países democráticos. Na mesma linha de raciocínio, Biazzi (2007, p. 16) complementa a sentença anterior quando diz: "[...] o setor público viu-se sob maior pressão para melhorar seu desempenho e demonstrar maior transparência e avaliação de resultados".

Tais necessidades de se aprimorar processos e melhoria de resultados na gestão em ambiente público surgiram de duas tendências: 1) a "onda" de reformas gerenciais (NOVA GESTÃO PÚBLICA) no setor público (início de 1980) e, 2) uma nova orientação das organizações públicas para os usuários clientes (orientação para o cliente) (ONGARO, 2004; WILLIAMS; SAUNDERS; STAUGHTON, 1999). Com relação ao mote, Ongaro (2004) considera que a orientação ao cliente (usuário final) pelas administrações públicas é vista como uma "legitimação" do setor público diante a sociedade. Sabendo que as organizações sofrem pressões por mudanças conforme seu ambiente de atuação (FILHO; VILHENA; NASCIMENTO, 2014), percebe-se ao longo dos anos que a administração pública tem sido confrontada com muitas exigências (BECKER; ALGERMISSEN; NIEHAVES, 2006), principalmente relacionadas às novas tecnologias que possam proporcionar serviços públicos de qualidade. Contudo, apesar da melhoria dos processos se nortearem pela utilização de tecnologias, o elemento humano é quem o realiza em todas as atividades para atender às diversas demandas que sobrevêm sobre esse fato (FALCÃO JÚNIOR, 2016). Desse modo, são as pessoas, capacitadas e motivadas, que executam processos e contribuem com os resultados propostos de uma organização (BRASIL, 2009).

Sendo uma organização, pública ou privada, estas devem possuir um conjunto de processos interrelacionados com a finalidade de alcançar seus objetivos e metas institucionais. Destarte, um processo possui uma ordem específica das atividades de trabalho considerando o tempo e o espaço, como um início e um fim, bem como inputs e outputs visivelmente identificados, a fim de produzir um resultado específico para um cliente ou mercado particular (DAVENPORT, 1994).

A literatura identifica 3 (três) tipos de processos organizacionais: gerenciais, finalísticos e administrativos. Apesar dos processos terem características específicas, os três tipos relacionados possuem aspectos em comum, como: envolver o encadeamento de atividades conectadas e interdependentes (transformação de entradas em saídas); possuir início e fim; possuir clientes, estes internos ou externos à organização (BIAZZI; MUSCAT; BIAZZI, 2011).

Tais processos são efetivados de modo contínuo pelo pessoal que faz parte da sua força de trabalho. Desse modo, se os processos são gerenciados com êxito pelos membros da organização, podem 
contribuir para alcançar a estratégia da empresa e melhorar a gestão dos processos principais, que agregam valor ao cliente (SENTANIN; CÉSAR; JABBOUR, 2008).

Domingues, Xavier e Birochi (2015) defendem que o foco nas pessoas é um dos aspectos da gestão por processos mais importantes, pois retratam a essência dos processos. Os autores destacam ainda que as pessoas que realizam as atividades e implementam melhorias em processos precisam ser motivadas para a realização das suas atividades.

Por outro lado, Carvalho (2015, p. 98) alerta sobre a existência de obstáculos, ou fatores "dificultadores" que podem impedir uma implantação da gestão por processos nas organizações com sucesso, como: "cultura organizacional; falta da visão por processos; resistência às mudanças de ambiente interno; falta de apoio da alta administração; falta de comprometimento dos funcionários; infraestrutura precária; falta de capacitação para os funcionários etc.". Segundo a autora, quando tais fatores são executados de maneira positiva são conhecidos como "fatores críticos de sucesso". Dentre tais fatores a falta de capacitação de funcionários pode ser um grande obstáculo para implementação de projetos de melhorias em processos.

Buh, Kovačič e Štemberger (2015, p.246, tradução nossa) concordam que colaboradores devem entender "os objetivos, o conteúdo, os papéis e responsabilidades da Gestão de Processos e serem informados sobre o seu progresso". Entende-se assim que a articulação das relações humanas com processos é importante para atribuir responsabilidades.

Com isso, a necessidade de se adotar abordagens mais flexíveis e estratégicas para organizações públicas induziu muitos pesquisadores a extrair práticas de gestão da literatura de negócios com o intuito de aplicálas na administração pública (PATELI ; PHILIPPIDOU, 2011). Considera-se neste sentido, a importância do uso de técnicas e ferramentas gerenciais da iniciativa privada adaptadas (ŠTEMBERGER; KOVACIC; JAKLIČ, 2007). Conforme os autores, a mudança de processos de negócios no ambiente público está relacionada principalmente à unificação dos processos de negócio, à automação de algumas atividades e à supressão de algumas desnecessárias. Outro fato também importante é que as instituições desenvolvam e implementem estratégia a fim de haver uma melhoria da qualidade de forma contínua (HAMZA, HASSANE ALHADIDY, 2010). Dentro do contexto, a abordagem de gestão por processos, no âmbito do setor público, ganhou espaço com a criação de programas de prêmios de qualidade. A exemplo do Brasil, por volta da década de 1990, houve a introdução do conceito de qualidade total e reengenharia, fundamentando-se nos critérios do Prêmio Fundação Nacional da Qualidade. O último programa foi o Programa Nacional de Gestão Pública e Desburocratização(GesPública).

Este foi estabelecido pelo Decreto no 5.378 (BRASIL, 2005), revogado pelo Decreto no 9.094 (BRASIL, 2017) e tinha como objetivo contribuir para a melhoria da qualidade dos serviços públicos prestados aos cidadãos e o foco em resultados. O programa, orientado pelo Modelo de Excelência da Gestão Pública (MEGP), teve como embasamento os princípios constitucionais da Administração Pública (legalidade, impessoalidade, moralidade, publicidade e eficiência).

O MEGP se estrutura em 8 (oito) critérios: governança, estratégias e planos, cidadão-usuário, interesse público e cidadania, informação e conhecimento, pessoas, processos e resultados (Figura 1). Tais critérios são compostos por itens de avaliação com distribuição de pontos que podem variar de 250, 500 ou 1000 no somatório dos itens pelo Instrumento de Autoavaliação da Gestão Pública (IAGP). Este além de determinar o estágio de maturidade da gestão é um sistema de avaliação que possibilita clarificar os pontos fortes e as oportunidades de melhoria (aspectos gerenciais menos desenvolvidos na gestão em relação ao modelo) e que devem ser objeto de ações de aprimoramento. 
Figura 1 - Representação gráfica do Modelo de Excelência em Gestão Pública

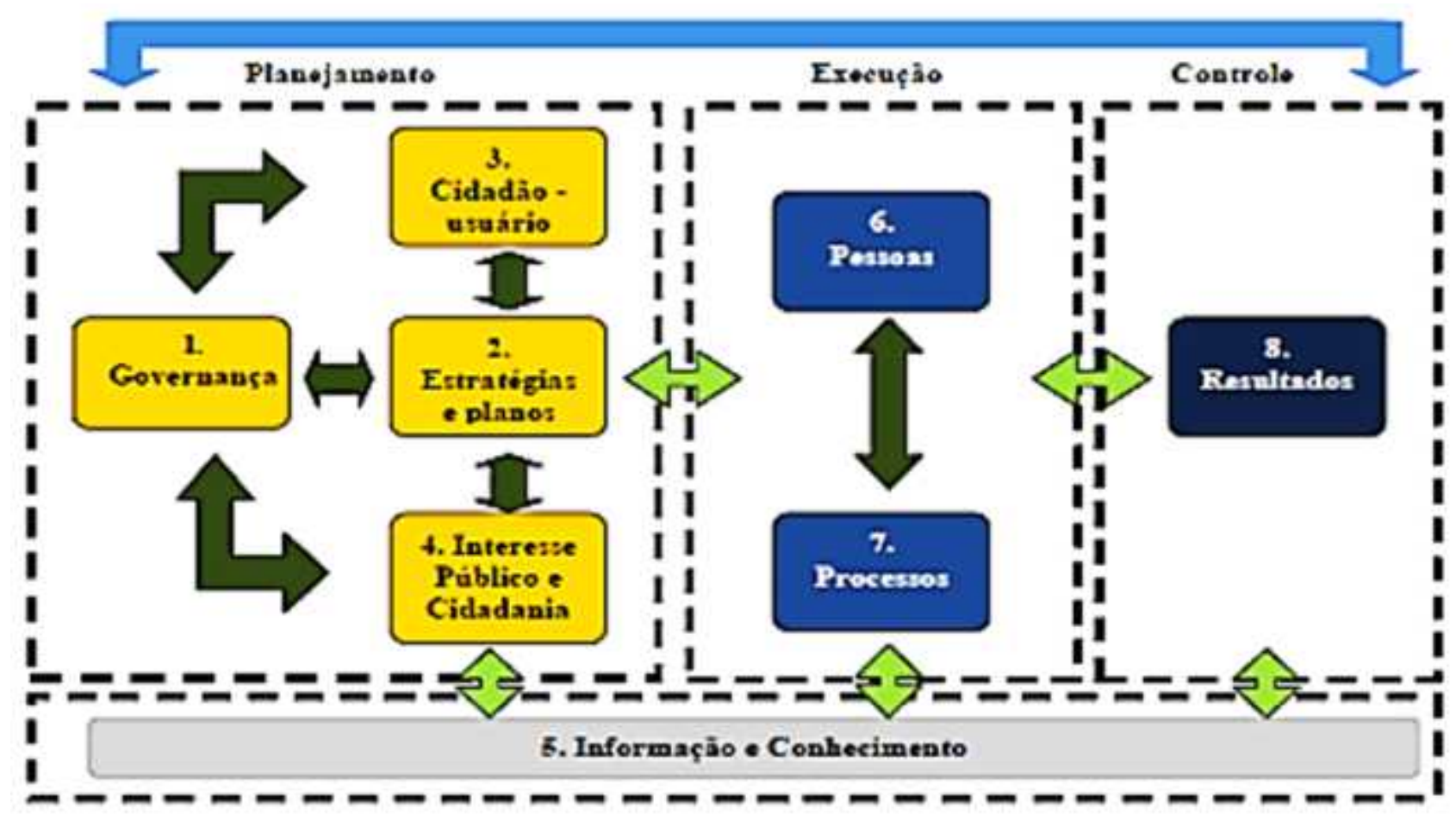

Avaliagào

Fonte: Adaptado de Brasil (2016, p. 6)

A Figura 1 evidencia a relação sistêmica que existe entre os critérios (setas maiores) e entre as partes do modelo (setas menores) que juntos representam os 8 (oito) critérios do Modelo de Excelência em Gestão Pública. Estes critérios fazem parte de uma sistemática de avaliação da gestão, tomando-se como referência o estado da arte em gestão, cujo método foi desenvolvido a partir dos prêmios nacionais da gestão (Brasil, 2009). Neste trabalho serão analisados os 2 (dois) critérios (Pessoas e Processos) que fazem parte da execução de um planejamento organizacional.

Ainda que não tivesse uma obrigatoriedade legal, o GesPública deixou como contribuição para as organizações públicas algumas ferramentas e fundamentos como a orientação por processos e informações. Destarte, o programa forneceu tecnologias de gestão a fim de instigar e promover a melhoria continuada de processos gerenciais e de

resultados aos órgãos e entidades públicas que delas se apropriavam e que ainda podem ser utilizadas, a saber: Guia de Gestão de Processos do Governo; Simplificação Administrativa - Guia "D"; Carta de Serviços ao Usuário; Indicadores de Gestão e o IAGP. Em ambiente universitário é possível que as universidades, em particular as públicas, realizem debates com base em princípios e conceitos de qualidade, sobre as perspectivas de aperfeiçoar seus processos para que possam cumprir seu papel social de promotoras do conhecimento. Em particular, no ano de 2011, a Universidade Federal do Tocantins aderiu ao Programa GesPública, parceiro da Fundação para o Prêmio Nacional da Qualidade (FPNQ). A instituição contou com os seguintes produtos do GesPública: a Autoavaliação da Gestão, realizada em 2011 por meio do IAGP e, a Carta de Serviços aos Usuários ainda em uso conforme obrigatoriedade legal. A universidade pública brasileira, diante de suas diversas responsabilidades e frente ao atual contexto de mudanças e transformações sociais, pode ter, em 
termos gerenciais, um instrumento de fundamental importância: a gestão de processos. No caso em particular, na UFT, este pode ser um estímulo à busca pela qualidade e um contributo importante para o atendimento às demandas governamentais e da sociedade. Entender como estão as práticas de Gestão de Processos por meio das contribuições do GesPública tende a trazer vantagens. Roczanski (2009, p. 4) afirma que:

A gestão dos processos das organizações pode contribuir de maneira significativa para a gestão estratégica e a melhoria contínua das mesmas. Desta forma, os processos de trabalho em instituições referem-se à essência e a caracterização da atuação da organização e estão diretamente relacionados aos seus objetivos estratégicos e à geração de produto/serviço para o cliente-usuário interno ou externo. (ROCZANSKI, 2009, p. 4)

Como referenciado, nos últimos anos, o foco em processos vem se tornando cada vez mais popular no setor público em geral, incluindo-se neste o ensino superior (MACINTOSH, 2003). Hamza, Hassan e Alhadidy (2010) confirmam que a gestão de processos é o modelo mais apropriado para implementar a qualidade em ambientes universitários.

No caso da Universidade Federal do Tocantins, as demandas para identificação de processos (mapeamento e modelagem) para fins de organização do trabalho em 2016 surgiram por meio dos planos e relatórios institucionais da Universidade, como o Planejamento Estratégico (2014 a 2022), o Plano de Desenvolvimento Institucional (2016 a 2020) e as oportunidades de melhorias apontadas pelo Relatório do GesPública em 2011. A próxima seção mostra a metodologia adotada para se cumpriro propósito deste trabalho.

\section{METODOLOGIA}

Este capítulo descreve o percurso metodológico adotado para se atingir o objetivo deste artigo relacionado à avaliação de iniciativas de gerenciamento de processos da UFT que precisam ser melhoradas. Enfatiza-se que os resultados são recorte de um objetivo específico da Dissertação da autora mencionada neste artigo.

O lócus da pesquisa foi a Universidade Federal do Tocantins, Câmpus de Palmas, especificamente a Reitoria. A amostra da pesquisa é formada por 5 (cinco) Pró-Reitorias, num total de 7 (sete), ao nível estratégico e tático ao selecionar 10 (dez) gestores, sendo 5 (cinco) pró-reitores e 5 (cinco) diretores.

A seleção das unidades gestoras ocorreu levando-se em consideração a experiência delas com a gestão administrativa e a proximidade com os processos gerenciais, administrativos e finalísticos, bem como pelas necessidades de práticas de gestão de processos nos setores. Desta forma, foram entrevistados ${ }^{1}$ os gestores que atuam nos seguintes setores: Pró-Reitoria de Graduação e Diretoria 
de Registros Acadêmicos; Pró-Reitoria de Pesquisa e Pós-Graduação e Diretoria de Pesquisa; PróReitoria de Extensão, Cultura e Assuntos Comunitários e Diretoria de Extensão; Pró-Reitoria de Avaliação e Planejamento e Diretoria de Planejamento; Pró-Reitoria de Administração e Finanças e Diretoria de Compras e Materiais.

Em termos de procedimentos técnicos esta pesquisa se define quanto à abordagem do problema em pesquisa qualitativa, pois responde a um "universo de significados" e de percepções pessoais (MINAYO, 2001, p. 14). Com relação aos objetivos é uma pesquisa descritiva pela descrição de fatos e fenômenos de uma realidade local, a UFT, por meio de declarações pessoais e outras informações pertinentes conforme Triviños (1987) ressalta neste sentido. Já quanto aos meios de investigação é uma pesquisa bibliográfica pela construção e compreensão do referencial teórico. A pesquisa se enquadra também como estudo de caso por ser uma estratégia metodológica que mostrou o que é realizado na prática, com o uso de técnicas de entrevistas aplicadas in loco. Nesse contexto, Yin (2001, p. 32) reforça que "o estudo de caso [...] investiga um fenômeno contemporâneo dentro de seu contexto da vida real, especialmente quando os limites entre o fenômeno e o contexto não estão claramente definidos".

Em relação à fase de coleta de dados foi aplicado um roteiro de entrevista semi estruturada para captar as falas e percepções de gestores da UFT baseado no IAGP (250 pontos) com foco específico nas alíneas que tratam sobre pessoas e processos, entre outras questões relacionadas aos fundamentos do BPM. Segundo Godoy, Bandeira de Mello e Silva (2006), a entrevista do tipo semi-estruturada visa compreender os significados que os entrevistados relacionam às questões e situações referentes ao tema de interesse do estudo.

Neste artigo, o intuito foi mostrar de forma focalizada a representatividade dos 2 (dois) critérios (Pessoas e Processos) que se referem a execução do planejamento de uma organização e, que se encontram dentro do Modelo de Excelência em Gestão Pública. No entanto, reconhece-se a importância da integração de todos os 8 (oito) critérios dentro do modelo.

Para o exame dos dados coletados, foi realizada a análise de conteúdo com base nas orientações de Bardin (1977). A autora afirma que esta é um conjunto de procedimentos sistemáticos para a descrição do conteúdo das mensagens. A finalidade deste tipo de análise é a inferência de conhecimentos relativos às condições de produção de dados, assim como a busca de sentidos de um documento, de uma fala atribuídos pelos sujeitos da pesquisa.

Considerou-se também uma triangulação dos dados, que segundo Creswell é uma estratégia para se confirmar resultados de pesquisas qualitativas (CRESWELL, 2007), com uso de diferentes fontes de evidências (YIN, 2001), sendo o levantamento das entrevistas confrontadas com a fundamentação teórica. A próxima seção apresenta e discute os resultados que favoreceu o alcance do objetivo deste artigo por meio do percurso metodológico da pesquisa proposto.

\section{APRESENTAÇÃO E DISCUSSÃO DOS RESULTADOS}

Apresentam-se neste capítulo os resultados da pesquisa com as discussões e análises provenientes das entrevistas semi-estruturadas com apoio do referencial teórico. O Quadro 2 mostra as 2 (duas) categorias e assuntos analisados.

Quadro 2- Categorias temáticas para análise na percepção dos gestores 


\begin{tabular}{|c|c|}
\hline CRITÉRIO/CATEGORIA & ASSUNTOS ANALISADOS NAS QUESTÕES \\
\hline 6 Pessoas & $\begin{array}{l}\text { - Integração dos níveis gerenciais da universidade em relação ao fluxo de } \\
\text { informações; } \\
\text { - Alinhamento das necessidades dos funcionários com processos } \\
\text { e sistemas de trabalho no setor; } \\
\text { - Cultura organizacional diante de mudanças em processos } \\
\text { de trabalho. }\end{array}$ \\
\hline 7 Processos & $\begin{array}{l}\text { - Conhecimento dos processos finalísticos, de apoio e gerenciais da UFT; } \\
\text { - Melhor divulgação de processos finalísticos e apoio; } \\
\text { - Articulação dos processos finalísticos e de apoio com a missão da UFT; } \\
\text { - Sugestões de melhorias em processos finalísticos e de apoio; • O processo } \\
\text { de elaboração e o processo de gerenciamento do orçamento; } \\
\text { - Critérios para seleção de fornecedores de serviços; } \\
\text { - O controle de processos finalísticos a partir de gerentes de processos; } \\
\text { - Escritório de processos na UFT. }\end{array}$ \\
\hline
\end{tabular}

Fonte: Elaborado pela primeira autora a partir do IAGP 250 Pontos do GesPública e referencial teórico.

A análise dos temas do Quadro 2 ocorreu por meio de uma avaliação entre pontos positivos e negativos de cada categoria temática, conforme se segue:

\section{I-Categoria 6-Pessoas}

Esta categoria retrata os resultados das opiniões dos gestores entrevistados sobre a integração dos níveis gerenciais da Universidade em relação ao fluxo de informações, ao alinhamento das necessidades dos funcionários com processos e sistemas de trabalho no setor e à cultura organizacional frente às mudanças em processos de trabalho.

Segundo Domingues, Xavier e Birochi (2015), as decisões gerenciais quando passam a ser internalizadas, compreendidas e decididas pela visão de processos, possibilitam maior eficiência e benefícios. Desta forma, o sucesso de uma instituição depende cada vez mais do conhecimento, das habilidades, da criatividade e da motivação de sua força de trabalho, o que foi reforçado na opinião dos gestores entrevistados.

O primeiro ponto positivo desta categoria pela opinião dos gestores é que a maioria destes disse que a integração entre os níveis gerenciais da Universidade, levando em consideração a tomada de decisão e fluxo de informações entre as outras unidades se dá por meio de reuniões de gestão periódicas, pelos debates de demandas nos Conselhos Superiores ou indiretamente por meio dos fluxos dos processos de trabalho. As frases seguintes exemplificam alguns dos dizeres:

Olha, dentro da alta administração, ocorre uma vez por semana reunião de gestão [...] promovida pela própria PROAP [...] onde se faz uma avaliação conjunta da necessidade e principalmente da divisão orçamentária que também estão incluídos os diretores, ou UGs, a unidade de gestão (E1PR, grifo nosso).

[...] a integração ocorre da seguinte forma, os servidores e estudantes fazem 
suas demandas ao seu superior hierárquico que vai debater isso nos conselhos superiores. [...] os conselhos são formados por pessoas representativas tanto da gestão quanto da comunidade acadêmica (E5PR, grifo nosso).

$\mathrm{Na}$ nossa parte acadêmica cada processo tem um fluxo específico e é diferenciado. Então cada processo [...] vai ter uma unidade que é ela que vai ter um momento de tomada de decisão. Então essa integração, ela acaba que tem que ocorrer, não tem muita opção por que é necessária para o processo. Então acaba que todo mundo vai se adequar ao fluxo e ao processo. Por que é necessário para a tomada de decisão(E4DR, grifo nosso).

Outro ponto positivo é com relação ao alinhamento das necessidades dos funcionários com processos e sistemas de trabalho. Os gestores entrevistados, mesmo que busquem uma melhor gestão dos seus processos, atividades e execução de ações estratégicas, procuram uma harmonia no ambiente de trabalho com seus servidores, favorecendo a formação e a capacitação destes de forma a viabilizar o trabalho. Neste sentido, E6DR diz que "A gente tenta verificar na própria formação do servidor [...] então isso teoricamente já estão todos bem alinhados ao que fazem, gostam; já fizeram vários cursos [...] vários cursos na sua área de atuação [...]". Outro entrevistado enfatiza "[...] as atividades são feitas com base nas capacidades e nas aptidões de cada servidor [...], a gente chama, conversa e mostra e pergunta se tá tudo bem e tenta viabilizar aquele trabalho ali [...]" (E5PR). Diante disso, Navaratnam e Harris (1995) advogam que as relações humanas atreladas aos processos são importantes por 2 (duas) razões: atribuir responsabilidades e estabelecer a cultura da organização.

Como ponto negativo tem-se o fator "resistência" diante uma cultura organizacional ao lidarem com as mudanças em processos de trabalho, este evento na opinião da metade dos gestores. E6DR evidencia este fato quando diz: "[...] minha experiência também enquanto servidor da UFT anterior, sempre a mudança é recebida com receio. Ninguém quer sair do seu nicho de trabalho". As falas de outros gestores também ratificam tal colocação:

Eu acredito que a cultura da UFT é um pouco resistente a questões de mudança. Nós demoramos um tempo de resposta talvez um pouco maior do que seria esperado ou que seria o ideal. Então essas melhorias, elas como a gente tem uma resistência a mudanças, a gente demora um tempo (E2DR, grifo nosso).

Temos resistências, temos as pessoas que estão abertas a estas mudanças, mas o que eu sinto de uma forma um pouquinho mais intensa é a falta da relação das atividades que são desenvolvidas nos setores com uma função que é da universidade [...] (E3PR, grifo nosso).

Tem-se que a implementação de gestão de processos, BPM, em uma organização tende a gerar resistências geralmente pelas transformações na rotina de trabalho dos colaboradores e de procedimentos organizacionais. 
Sabendo que a mudança de cultura é um dos fatores de sucesso em transformações organizacionais (MCADAM; MITCHELL, 1998; ŠTANGOVÁ; VÍGHOVÁ, 2014), a maneira como aquela é incorporada é um dos maiores fatores responsáveis para sua aceitação com geração de resultados (TEIXEIRA LAGIOIA et al., 2008). Nesse sentido, Duvell e Jordan (2003) afirmam que a cultura organizacional se refere a uma série de premissas, estereótipos e mitos.

Foi mostrado nesta categoria como é importante a integração entre os níveis estratégicos da UFT e estabelecer relações com as pessoas a fim de criar condições de melhoria da qualidade nas relações de trabalho. Isto pode estabelecer uma sincronia na realização humana e profissional. Na próxima categoria são abordados assuntos relacionados à categoria Processos, mostrando a percepção dos gestores diante da identificação, divulgação, de melhorias em processos, gerência e escritório de processos.

\section{II - Categoria 7-Processos.}

Esta categoria se refere à opinião dos gestores entrevistados com relação à gestão, divulgação e melhoria dos processos finalísticos, de apoio e gerenciais, bem como o entendimento sobre gestores de processos e perspectiva de um escritório de processos na UFT. Conforme a literatura relata, ter um entendimento sobre os processos e compartilhar o conhecimento entre a organização como um todo e, principalmente, entre gestores de níveis hierárquicos diferentes, é fator indispensável para o aumento do desempenho de uma organização, inclusive para a implementação do BPM.

Paulus e Riemann (2013) ressaltam que a identificação do processo de negócio permite conhecer por que os processos de negócios são essenciais para a organização no sentido de cumprir as necessidades dos clientes ou de outras partes interessadas referentes ao modelo de negócio e à estratégia de resultados.

Entre os pontos positivos encontrados, no primeiro desta categoria, percebe-se que a maioria dos gestores conhece os processos finalísticos e de apoio da universidade, como se observa nos exemplos das falas a seguir.

Eu conheço alguns processos finalísticos [...] dentro do setor aqui. Eu posso citar que foi mapeado o do sistema de planejamento anual, foi mapeado o processo de construção do relatório de gestão, o processo de organização e distribuição do orçamento (E2DR).

Sim, a gente conhece. Talvez não conheça todos os mecanismos gerenciais, mas os processos finalísticos nossos estão basicamente relacionados com a qualidade dos cursos de pós-graduação, com a captação de recursos para pesquisa [...] com o sucesso de formatura de nossos estudantes, na obtenção dos graus de especialista, mestre, doutor e pós-doutor [...] (E5PR).

As frases citadas demonstram que uma das vantagens que a Universidade possui neste momento é ter divulgados muitos modelos de processos, organizados ainda por setor, devido ao seu caráter funcional e hierárquico. Pode-se dizer que, apesar da UFT ainda estar caminhando, olhando para os seus processos a fim de melhorias, está implantando uma cultura de conhecimento, de modo a 
familiarizar as pessoas com a importância de seus processos de trabalho. E5DR neste contexto comenta: "Essas melhorias que foram realizadas, como por exemplo, a determinação dos fluxos e o esclarecimento de todas as etapas de cada unidade ter competências foi fundamental porque permite um melhor planejamento [...] todos os passos estão bem determinados"(E5PR).

O segundo ponto positivo considerado nesta pesquisa diante desta categoria foram as sugestões para a divulgação dos processos. Os gestores citaram investir em propaganda; tecnologia; comunicação; ter o processo como instrumento de decisão; haver mais comunicação; ter cerimônia de entrega dos diplomas de especialização; engajamento dos colegiados; haver melhoria no site da UFT; divulgar em mídias sociais.

Entre todas as sugestões supracitadas os fatores "comunicação" e "tecnologia" foram os mais comentados. Segundo um dos gestores entrevistados, para se melhorar a comunicação na Universidade, esta deveria estar mais aberta para a sociedade: "Nós ainda estamos muito fechados dentro da instituição" (E7PR). Neste sentido, a comunicação torna-se um dos elementos relevantes durante a implementação de um projeto de BPM e gestão de processos numa organização (MANFREDA; BUH; ŠTEMBERGER, 2015), por interferir nas relações organizacionais. Quanto à tecnologia, Gulledge Jr e Sommer (2002) ressaltam que estabelecer uma relação entre os processos organizacionais com novas tecnologias de informação é uma das razões para se implementar a gestão de processos na administração pública. A UFT neste quesito vem tentando melhorar cada vez mais, o que pode ser verificado no Relatório de Gestão de 2016, com apresentação dos resultados da gestão da informação da Universidade.

O terceiro ponto positivo quanto à articulação dos processos finalísticos e de apoio com a missão é que a maioria dos gestores confirma este fato ao se referirem ao PDI. E3PR comenta que "Eles estão articulados em termos do projeto da universidade, por exemplo, no Plano de Desenvolvimento Institucional e isso com certeza lá tem uma relação". Outro gestor também enfatiza "Como a universidade hoje toda praticamente trabalha em cima do PDI, todas as ações que viram fluxos, elas são do PDI. Então tudo está articulado com a missão institucional" (E4DR). Outro relato diz:

Nós temos como base todo o trabalho da pró-reitoria. Planejamento feito com base no PDI. Esses processos, eles foram pensados já conforme a gente já articulou dentro das diretrizes e dos eixos do planejamento que eles estão intimamente ligados com nossa missão (E2DR).

A literatura comenta que é relevante o alinhamento dos processos com a estratégia e a missão de uma instituição. Segundo Sentanin, César e Jabbour (2008), os processos de negócios de uma organização devem estar direta ou indiretamente articulados com o seu planejamento estratégico, caso contrário pode ocorrer um consumo de recursos capaz de desestruturar outros processos.

O quarto ponto positivo se refere às sugestões de melhorias em processos na opinião dos gestores entrevistados, conforme a Figura 2. Observou-se pela Figura 2 que todos estes aspectos levantados pelos gestores são relevantes do ponto de vista do aperfeiçoamento dos resultados dos processos finalísticos e de apoio, a partir de melhorias a serem implementadas. Neste sentido, Biazzi, Muscat e Biazzi (2011) ressaltam que projetos de melhorias devem ser adaptados ao contexto do setor público pelo fato de existirem aspectos característicos desse ambiente como a cultura organizacional típica, 
questões políticas e burocracia. Deve-se levar em consideração, também, nas mudanças contínuas de processos de negócios no setor público, o foco no cliente (ŠTEMBERGER; KOVACIC; JAKLIČ, 2007).

Figura 2 - Sugestões de melhorias em processos finalísticos e de apoio na opinião dos gestores entrevistados

\section{Sugestőes de melhorias em processos}

Realizar reuniōes de gestão dos entes operadores

Levantar riscos dos processos; Levantar necessidades do usuário a partir do serviço

Incentivar processo formativo para o desenvolvimento de atividades

Padronizar os processos; Automatizar processos

Alocar mais recursos nos processos e atividades

Conscientizar os docentes com a missão

Melhorar os processos avaliativos das ações finalisticas; Aplicação de questionários para os usuários de serviços

Dar mais amplitude e visibilidade aos processos finalisticos e de apoio

Discutir a aplicação de recursos das ações da UFT

Aproximar a gestão superior das áreas de apoio com discussão

Fonte: Elaborado pela primeira autora a partir da pesquisa de campo.

O quinto ponto positivo relacionado ao processo de elaboração e o processo de gerenciamento do orçamento mostra que os gestores são unânimes no fato de terem conhecimento de que os processos de elaboração e gerenciamento do orçamento levam em consideração o histórico e metas atingidas. E1PR neste sentido comenta "Até esse momento considera o histórico e a uma [...] distribuição atrelada ao mesmo critério da do MEC." E2DR, por sua vez, também diz "O processo de planejamento orçamentário leva em consideração o histórico do que já foi feito [...]". E8DR ainda comenta que "eles levam, até mesmo porque tem uma matriz orçamentária [...]". Outras falas na mesma linha de raciocínio ressaltam:

Ah sim, totalmente, pelo menos nesse período que a gente tem aqui toda reunião de gestão é apontado números anteriores [...] exemplo prático aqui [...] quantas bolsas tínhamos ano passado, quantas a gente vai ofertar, quanto a gente tem de verba para ele, quantas a gente atingiu [...] (E6DR). 
[...] é possível dizer que ela leva em consideração sim o histórico nos últimos tempos [...] ficou mais difícil [...] devido à escassez de recursos [...] contingenciamento de recursos do governo federal." (E10DR).

Pelas falas acima é possível observar que os gestores têm conhecimento sobre o fato dos processos de elaboração e gerenciamento do orçamento considerarem o histórico e as metas atingidas. Contudo, uma realidade vista como fator capaz de mudar essa situação é a questão do contingenciamento de recursos vivenciado nos últimos anos. Verificou-se isso pelos discursos seguintes: "[...] nem sempre as nossas metas estratégicas são atendidas em função dos cortes [...]" (E3PR); “[...] ficou mais difícil levar em consideração o histórico devido à escassez de recursos, o contingenciamento de recursos do governo federal e a gestão tá tendo que tomar medidas contingenciais para poder atingir suas metas" (E10DR).

Em relação ao sexto ponto positivo, todos os gestores reconhecem que para a seleção de fornecedores de serviços deve-se obedecer aos preceitos legais. Algumas verbalizações podem ser observadas para exemplificar estes resultados: "Isso não é tanto aqui na minha área, mas é considerado a princípio aquele que se atrela a exigência da licitação primeiro, aquele jurídico e depois de preço" (E1PR); “[...] Eu acredito assim que ligo para a gente fazer contratação de qualquer serviço, nós fazemos um processo licitatório"(E2DR); “[...] a gente não tem muito a parte de fornecedores de serviços, mas creio que no ambiente a maioria é licitação [...]"(E3PR). Outra resposta se referiu à legislação: “[...] Lei 8.666 [...] a lei de licitações e compras no serviço público nós temos que obedecer este preceito [...]" (E9PR);

O sétimo ponto positivo mostra que os gestores sabem que os processos precisam ser gerenciados, eles têm essa consciência evidente nas falas. Neste sentido, a literatura fala que o gestor de processos é muito importante numa abordagem de BPM, sendo figuras essenciais, pois acompanham, dão suporte e gerenciam os processos organizacionais ponta a ponta, bem como lidam com mudanças necessárias nos departamentos envolvidos.

Maddern et al. (2014) ressaltam que os gestores devem sair de um nível gerencial funcional para um nível de gerenciamento de processos ponta a ponta a fim de realizar uma série de melhorias de desempenho bem como buscar a satisfação do cliente. $O$ verdadeiro papel de um proprietário, dono ou gerente do processo é ter a responsabilidade sobre operações de processo, ocupando uma posição relativamente alta na organização (BUH; KOVAČIČ; ŠTEMBERGER, 2015).

O oitavo ponto positivo abordado pelos entrevistados foi alguns se mostrarem receptivos a existência de um escritório de processos na UFT, ainda que numa minoria de 3 (três) gestores. Um desses gestores, E8DR, comenta "Eu acho que vai vir de grande valia acho que vai agregar, vai somare a gente precisa melhorar os fluxos" (E8DR).

Entre os pontos negativos encontrados nesta categoria pelos resultados das entrevistas verificou-se que 4 (quatro) dos 10 (dez) gestores não se mostraram receptivos quanto à proposta de um escritório de processos, 3 (três) demonstraram não compreender bem suas funcionalidades. Entre os que não se mostraram receptivos, os relatos foram "[...] eu acho que não seria o primordial [...] ter um escritório exclusivamente para isso eu acho que não tem necessidade. [...]" (E7PR). Outro gestor, E1PR, por sua vez diz: "Eu acho que não precisa, acho que se cria muita identidade [...] Não realmente formalizada dessa forma [...]". E2DR também comenta: "[...] eu não sei exatamente se teria uma 
característica de escritório de processos [...] mas a universidade, ela precisa estruturar e ela já começou os trabalhos". Por fim, E9PR relata: "Eu acho que é inviável por enquanto [...]" (E9PR).

Entre as justificativas declaradas quanto à resistência para a implantação de um escritório de processos na UFT alguns gestores ressaltam: "faz parte intrínseca da responsabilidade das atividades do Planejamento" (E1PR); "por questões de gratificação, quadro de servidores [...] formações de novas diretorias novos setores não tem tido muito êxito em função disso" (E9PR).

Diante da literatura acadêmica, o escritório de processos pode possibilitar a realização da gestão com abordagem em processos numa organização (DOMINGUES; XAVIER; BIROCHI, 2015). Neste sentido, o escritório de processos pode ser implantado em diversas formas de estruturas organizacionais e sua atuação irá depender da visão que a organização tem dos seus processos (CARVALHO, 2015; OLIVEIRA, 2014).

Ademais, em um escritório de processos deve existir um gerente que responda à alta gestão, bem como um conjunto de procedimentos e regulamentações. Entretanto, há muitos fatores que podem influenciar a implementação de BPM relacionada à estruturação do escritório, como cultura, comunicação e patrocínio (OLIVEIRA, 2014).

Também como pontos negativos, estão uma minoria de gestores que não conhece o funcionamento de alguns processos de outros setores. E4DR neste caso diz: "Bom, na verdade eu creio que a gente conhece mais os processos que a gente trabalha. Então não temos muito conhecimento exceto a parte geral que envolve todas as pró reitorias [...]". Outro entrevistado também comenta: "Sim, tenho conhecimento dos processos finalísticos na instituição de ensino no caso da Universidade - ensino, pesquisa e extensão -, mas não tenho muita propriedade para falar sobre o desenrolar de como se processa" (E10DR).

Outros pontos negativos se referem às falas de alguns gestores, 3 (três) no total: em relação a não possuírem informação suficiente sobre as principais competências e funções do gerente de processo, bem como de um Escritório de Processos numa organização que pretende implementar melhorias em processos a partir do BPM.

Vimos nesta Categoria de Processos, na perspectiva de pontos positivos e negativos, as diversas percepções e opiniões dos entrevistados sobre os processos finalísticos, de apoio e gerenciais da UFT, sugestões para divulgação e melhorias de processos finalísticos e apoio, o conhecimento dos gestores quanto à articulação dos processos finalísticos e de apoio com a missão da UFT, comentários sobre o processo de elaboração e o processo de gerenciamento do orçamento, reconhecimento de critérios para seleção de fornecedores de serviços, a figura do gerente de processos e por fim, sobre o Escritório de processos na UFT.

Na próxima seção são mostradas as considerações finais e limitações a partir dos resultados desta pesquisa 


\section{CONSIDERAÇÕES FINAIS}

O objetivo deste artigo foi avaliar em que medida as iniciativas de gerenciamento de processos da Universidade Federal do Tocantins (UFT) precisam ser melhoradas. Para tais fins, foram analisadas as percepções, opiniões, negativas e sugestões da alta direção, incluindo pró-reitores e diretores, com critérios (Pessoas e Processos) relacionados a processos do Instrumento de Autoavaliação do extinto GesPública. Incluem-se na análise de resultados os fundamentos do Business Process Management a fim de fornecer ferramentas para a realização do artigo, em especial numa instituição de educação do setor público.

A pesquisa permitiu uma compreensão de que iniciativas, práticas ou conhecimento de gerenciamento de processos pelos gestores são adequadas ou não, existentes ou não. Desta forma, os resultados evidenciados no estudo mostraram que os gestores na atual estrutura administrativa da UFT estão em busca de melhorias nos processos que competem a sua gestão.

Como limitações da pesquisa, sendo a UFT uma instituição com atividades complexas, ocorreram dúvidas por parte de alguns gestores quanto ao significado de algumas perguntas e mudança de foco em algumas respostas, não impedindo a realização do trabalho.

Percebe-se que as administrações públicas, caracterizadas ainda de forma burocrática, poderão encontrar muitas dificuldades na implementação da gestão de processos. Cabe à gestão da Universidade fortalecer os pontos positivos verificados nas percepções dos gestores e reparar os pontos negativos apontados nas falas, para que se realizem com sucesso as etapas de BPM na organização. 


\section{REFERÊNCIAS}

BARDIN, L. Análise de conteúdo. Tradução Luís Antero Rego e Augusto Pinheiro. Lisboa: Edições 70, 1977.

BECKER, J.; ALGERMISSEN, L.; NIEHAVES, B. A procedure model for process oriented e government projects. Business Process Management Journal, v. 12, n. 1, p. 61-75, 2006. http://dx.doi.org/10.1590/S0104$530 \times 2011000400013$

BIAZZI, M. R. de. Instituições públicas de ensino superior: estudo de casos de aperfeiçoamento de processos administrativos. 2007. Dissertação (Mestrado). Universidade de São Paulo. Disponível em: http://www.teses.usp.br/teses/disponiveis/3/3136/tde-09082007-181330/en.php. Acesso em: 30 jul. 2016.

BIAZZI, M. R.de; MUSCAT, A. R. N.; BIAZZI, J. L. de. Modelo de aperfeiçoamento de processos em instituições públicas de ensino superior. Gest. Prod., São Carlos, v. 18, n. 4, p. 869-880, 2011. http://dx.doi.org/10.1590/S0104-530X2011000400013

BUH, B.; KOVAČIČ, A.; ŠTEMBERGER, M. I. Critical success factors for different stages of business process management adoption-a case study. Economic Research-Ekonomska Istraživanja, v. 28, n. 1, p. 243-258, 2015. https://doi.org/10.1080/1331677X.2015.1041776

BRASIL. Decreto no 5.378 de 23 de fevereiro de 2005. Institui o Programa Nacional da Gestão Pública e Desburocratização - GESPÚBLICA. Diário Oficial [da] República Federativa do Brasil, Brasília, DF, 24 fev. 2005. p. 2. Disponível em: http://pesquisa.in.gov.br/imprensa/jsp/visualiza/index.jsp?jornal=1\&pagina=2\&data=24/02/2005. Acesso em: 15 maio 2016.

Ministério do Planejamento, Orçamento e Gestão. Secretaria de Gestão. Programa Nacional de Gestão Pública e Desburocratização - GesPública; Prêmio Nacional da Gestão Pública - PQGF; Documento de Referência; Fórum Nacional 2008/2009. Ministério do Planejamento, Orçamento e Gestão, Subsecretaria de Planejamento, Orçamento e Gestão. - Brasília: MP, SEGES, 2009. Disponível em: <http://www.planejamento.gov.br/secretarias/upload/Arquivos/segep/eventos/2013/documento _referencia2009_29abr.pdf/view>. Acesso em: 18 mai. 2016.

Ministério do Planejamento, Orçamento e Gestão. Secretaria de Gestão Pública. Programa GESPÚBL ICA, Instrumento par a Avaliação da Gestão Pública - 250 Pontos. Brasília; MP, SEGEP, 2015. Versão 1/2016. Disponível em: http://www.gespublica.gov.br/sites/default/files/documentos/gagp-250_pontos_novo.pdf. Acesso em: 12 mar. 2017.

. Decreto no 9.094, de 17 de julho de 2017.Dispõe sobre a simplificação do atendimento prestado aos usuários dos serviços públicos, ratifica a dispensa do reconhecimento de firma e da autenticação em documentos produzidos no País e institui a Carta de Serviços ao Usuário. Diário Oficial [da] República Federativa do Brasil, Brasília, DF, 18 jul. 2017. p. 2. 2017. Disponível em: http://pesquisa.in.gov.br/ imprensa/jsp/visualiza/index.jsp?jornal=1\&pagina=2\&data=18/07/2017. Acesso em: 18 jul. 2017.

CARVALHO, K. A.de. Gestão por processos organizacionais na Universidade de Brasília: estudo de caso Dissertação (Mestrado) - Universidade de Brasília - DF, 2015. Disponível em: <http://repositorio.unb.br/handle/10482/19446>. Acesso em:09 abr. 2016. 
CRESWELL, J. W. Projeto de pesquisa métodos qualitativo, quantitativo e misto. Projeto de pesquisa métodos qualitativo, quantitativo e misto. Tradução Luciana de Oliveira da Rocha. 2. ed. Porto Alegre: Artmed, 2007.

DAVENPORT, T.H. Reengenharia de processos: como inovar na empresa através da tecnologia da informação. Rio de Janeiro: Campus, 1994.

DOMINGUES, F. de M. F.V.; XAVIER, W. G.; BIROCHI, Renê. Gestão por processos: uma análise da ferramenta de gestão utilizada no poder judiciário de Santa Catarina. Revista Eletrônica de Estratégia \& Negócios, v. 8, n. 1, p. 199-238, 2015. http://dx.doi.org/10.19177/reen.v8e12015199-238

DUVELL, F.; JORDAN, B. Immigration control and the management of economic migration in the United Kingdom: organizational culture, implementation, enforcement and identity processes in public services. Journal of Ethnic and Migration Studies, v. 29, n. 2, p. 299-336, 2003. https://doi.org/10.1080/1369183032000079620

FALCÃO JÚNIOR, Marcos Antônio Gomes; SANTOS, Raimundo Nonato Macedo dos. A gestão de processos na análise das atividades de seleções públicas simplificadas: estudo de caso em uma prefeitura. Navus - Revista de Gestão e Tecnologia, [S.I.], v. 6, n. 2, p. 06-19, apr. 2016. https://doi.org/10.22279/navus.2016.v6n2.p06-19.324

FILHO, M. C. F.; VILHENA, M. das G.; NASCIMENTO, D. M. Gestão de processo na implantação de um Sistema de Informação Acadêmica: a experiência da UFPA. Revista Gestão Universitária na América Latina - GUAL, v. 7, n. 2, p. 69-85, 2014. http://dx.doi.org/10.5007/1983-4535.2014v7n2p69

GODOY, C. K; BANDEIRA DE MELLO, R. B. de; SILVA, A. B. da. Pesquisa qualitativa em estudos organizacionais, estratégias e métodos. São Paulo: Saraiva, 2006.

GULLEDGE JR, T. R.; SOMMER, R. A. Business process management: public sector implications. Business Process Management Journal, v. 8, n. 4, p. 364-376, 2002. http://dx.doi.org/10.1108/14637150210435017

HAMZA, T. T.; HASSAN, A.; ALHADIDY, M. A. Developing a Service Oriented Process Management System for University Quality Assurance. International Journal of Engineering Science and Technology, v. 1, n. 2, p. 7-17, 2010.

JURISCH, M. C.; IKAS, C.; WOLF, P.; KRCMAR, H. Key Differences of Private and Public Sector Business Process Change. e-Service Journal, v. 9, n. 1, p. 3-27, 2013. https://doi.org/10.2979/eservicej.9.1.3

MACINTOSH, R. BPR: alive and well in the public sector. International Journal of Operations \& Production Management, v. 23, n. 3, p. 327-344, 2003. https://doi.org/10.1108/01443570310462794

MADDERN, H.; SMART, P. A.; MAULL, R. S.; CHILDE, S. End-to-end process management: implications for theory and practice. Production Planning \& Control, v. 25, n. 16, p. 1303- 1321, 2014. https://doi.org/10.1080/09537287.2013.832821

MANFREDA, A.; BUH, B.; ŠTEMBERGER, M. I. Knowledge-intensive process management: a case study from the public sector. Baltic Journal of Management, v. 10, n. 4, p. 456-477, 2015. https://doi.org/10.1108/BJM-10-20140170

MCADAM, R.; DONAGHY, J. Business process re-engineering in the public sector: A study of staff perceptions and critical success factors. Business Process Management Journal, v. 5, n. 1, p. 33-52, 1999. https://doi.org/10.1108/14637159910249135

MCADAM, R.; MITCHELL, N. Development of a business process re-engineering model applicable to the public sector. Total Quality Management, v. 9, n. 4-5, p. 160-163, 1998. https://doi.org/10.1080/0954412988802 
MINAYO, M. C. de S. (org.). Pesquisa Social: teoria, método e criatividade. 18 ed. Petrópolis: Vozes, 2001.

NAVARATNAM, K. K.; HARRIS, B. Quality process analysis: a technique for management in the public sector. International Journal of Public Sector Management, v. 8, n. 1, p. 11-19, 1995. https://doi.org/10.1108/09513559510077797

NIEHAVES, B. Open process innovation: The impact of personnel resource scarcity on the involvement of customers and consultants in public sector BPM. Business Process Management Journal, v. 16, n. 3, p. 377-393, 2010. https://doi.org/10.1108/14637151011049412

OLIVEIRA, J. Fatores envolvidos na estruturação de um Escritório de Processos em uma organização pública: uma pesquisa-ação. 2014. Dissertação (Mestrado) - Universidade Federal de Pernambuco. Ciência da Computação. Disponível em: http://repositorio.ufpe.br/handle/123456789/11553. Acesso em:01 dez. 2017.

ONGARO, E. Process management in the public sector: the experience of one-stop shops in Italy. International Journal of Public Sector Management, v. 17, n. 1, p. 81-107, 2004. https://doi.org/10.1108/09513550410515592

PATELI, A.; PHILIPPIDOU, S. Applying business process change (BPC) to implement multi agency collaboration: the case of the Greek public administration. Journal of theoretical and applied electronic commerce research, v. 6 , n . 1, p. 127-142, 2011. https://doi.org/10.4067/S0718-18762011000100009

PAULUS, S.; RIEMANN, U. An approach for a business-driven cloud-compliance analysis covering public sector process improvement requirements. International Journal of Managing Public Sector Information and Communication Technologies, v. 4, n. 3, 2013. https://doi.org/10.5121/ijmpict.2013.4301

RADNOR, Z.; O'MAHONEY, J. The role of management consultancy in implementing operations management in the public sector. International Journal of Operations \& Production Management, v. 33, n. 11/12, p. 1555-1578, 2013. https://doi.org/10.1108/IJOPM-07-2010-0202

ROCZANSKI, C. R. M. A Gestão de Processos em Ambientes Universitários: o exemplo da Unicamp. IX Colóquio Internacional sobre Gestão Universitária na América do Sul. 2009. Disponível em: https://repositorio.ufsc.br/handle/123456789/25885/browse?value=ROCZANSKI\%2C+CARLA+ REGINA+MAGAGNIN\&type=author. Acesso em: 09 abr.2016.

SENTANIN, O. F.; CÉSAR, F. A. S.; JABBOUR, C. J.C. Business process management in a Brazilian public research centre. Business Process Management Journal, v. 14, n. 4, p. 483- 496, 2008. https://doi.org/10.1108/14637150810888037

ŠTANGOVÁ, N.; VÍGHOVÁ, A. Process Management--New Way Of Selfgovernment Functioning. European Scientific Journal, v.1, p.141-151, 2014.

ŠTEMBERGER, M. I.; KOVACIC, A.; JAKLIČ, J. A methodology for increasing business process maturity in public sector. Interdisciplinary Journal of Information, Knowledge, and Management, v. 2,p. 119-133, 2007. https://doi.org/10.28945/3156

TEIXEIRA LAGIOIA, U. C.; RIBEIRO FILHO, J. F; FALK, J. A.; LIBONATI, J. J.; DE GUSMÃO LOPES, J. E. A gestão por processos gera melhoria de qualidade e redução de custos: o caso da unidade de ortopedia e traumatologia do hospital das clínicas da Universidade Federal de Pernambuco. Revista Contabilidade \& Finanças, v. 19, n. 48, p. 77-90, 2008 http://dx.doi.org/10.1590/S1519-70772008000300007 
TRIVIÑOS, A. N. S. Introdução à pesquisa em ciências sociais: a pesquisa qualitativa em educação. São Paulo: Atlas, 1987.

UFT. Relatório de gestão do exercício de 2016. Palmas, TO: UFT, 2017a.

WILLIAMS, C. S.; SAUNDERS, M. N.; STAUGHTON, R. V.W. Understanding service quality in the new public sector: an exploration of relationships in the process of funding social housing. International Journal of Public Sector Management, v. 12, n. 4, p. 366-380, 1999. https://doi.org/10.1108/09513559910282858

YIN, R. K. Estudo de caso: planejamento e métodos. Tradução Daniel Grassi. 2.ed. Porto Alegre: Bookman, 2001. 


\section{A CONTRIBUIÇÃO DA PRÁTICA PARA A PESQUISA SOBRE $O$ USO DAS MÍDIAS SOCIAIS NA APRENDIZAGEM EM ORGANIZAÇÕES}

Mírian Assumpção e Lima

Departamento de Gestão Pública - DEGEP

Universidade Federal de Ouro Preto - UFOP

Helton Cristian de Paula

Departamento de Gestão Pública - DEGEP

Universidade Federal de Ouro Preto - UFOP

\author{
Wellington Tavares \\ Departamento de Gestão Pública - DEGEP \\ Universidade Federal de Ouro Preto - UFOP \\ Lelis Maia de Brito \\ Departamento de Gestão Pública - DEGEP \\ Universidade Federal de Ouro Preto - UFOP
}

\section{RESUMO}

As mídias sociais, ao possibilitarem o compartilhamento de informações e conhecimento, favorecem a interação e a aprendizagem. Ainda assim, são escassas as pesquisas e o emprego dessas tecnologias nos processos de aprendizagem em organizações. Este artigo teórico examina como a literatura sobre os modos de engajar a prática na pesquisa propostos por Orlikowski (2010) pode contribuir para a compreensão e a redução das lacunas existentes nos campos que investigam o fenômeno do uso das mídias sociais na aprendizagem em organizações (SCHEIN, 2014).

\section{Palavras-chave:}

Teoria da Aprendizagem Social; Teoria da Presença Social; Lentes teóricas; Paradigmas de Pesquisa.

\section{ABSTRACT}

Social media, by enabling the sharing of information and knowledge, favor interaction and learning. Even so, research and the use of these technologies in learning processes in organizations are scarce. This theoretical article examines how the literature on the ways of engaging practice in research proposed by Orlikowski (2010) can contribute to the understanding and the reduction of existing gaps in the fields that investigate the phenomenon of the use of social media in learning in organizations (SCHEIN, 2014).

\section{Keywords:}

Theory of Social Leaming; Social Presence Theory; Theoretical lenses; Research Paradigms. 


\section{INTRODUÇÃO}

O uso das mídias sociais (MS) na aprendizagem em organizações (AO) tem um apelo evidente para pesquisadores desse campo. As organizações e os indivíduos se favorecem do compartilhamento de informações e do conhecimento possibilitado pelas MS, uma vez que essas ferramentas proporcionam oportunidades para a interação e a aprendizagem continuamente no ambiente organizacional e fora dele (NISAR, PRABHAKAR e STRAKOVA, 2019). Além disso, as MS são baratas, de fácil manuseio, rápidas e de amplo alcance. Ainda assim, é inexpressivo o número de pesquisas sobre o emprego das MS nos processos de AO, mesmo que teoricamente o argumento para o uso dessas ferramentas tecnológicas na aprendizagem seja convincente (SCHEIN, 2014; ZHAO e KEMP, 2012).

As MS são aplicativos baseados na Internet que permitem a interação social por meio da criação e troca de conteúdo entre usuários (KAPLAN e HAENLEIN, 2010). A velocidade e o volume de dados, o amplo alcance e o fácil acesso e manuseio para coleta e envio de textos, áudios, funcionalidades das MS que favorecem a interação por meio do compartilhamento de conteúdo, são pouco utilizadas para aprendizagem e geração de conhecimento nos setores privado e público (NISAR, PRABHAKAR e STRAKOVA, 2019; SCHEIN, 2014).

Em sua maioria, as organizações que usam as MS buscam inicialmente a interação com o público externo, por meio de aplicativos abertos e de uso frequente. O emprego dessas ferramentas tecnológicas para a interação interna, a aprendizagem e a geração de conhecimento nas organizações é menos frequente e menos estudado (LEONARDI, HUYSMAN e STEINFIELD, 2013; NISAR, PRABHAKAR e STRAKOVA, 2019). Provavelmente, uma das razões por trás desse uso módico seja a falta de compreensão sobre o que são as MS e as várias formas que elas podem assumir e auxiliar nos processos organizacionais (KAPLAN e HAENLEIN, 2010).

É possível que as disfunções atribuidas a esses aplicativos, especialmente a desatenção no trabalho, justifiquem a limitação do emprego das MS pelas organizações, mesmo que seja difícil demonstrar que esse uso contribua para uma menor produtividade (SKEELS e GRUDIN, 2009). Estudos evidenciam o impacto das interações de MS no contexto de uso de sistemas corporativos demonstrando como a copresença virtual e os relacionamentos assegurados pelas MS "moldam as interações entre os usuários de sistemas corporativos e a conclusão coletiva de tarefas em um contexto de trabalho disperso" (SUBRAMANIAM, NANDHAKUMAR e BAPTISTA, 2013, p.475). Também que as mídias sociais corporativas permitem benefícios significativos como soluções mais rápida de problemas e melhores práticas (NISAR, PRABHAKAR e STRAKOVA, 2019). Contudo, são incontestáveis os desafios trazidos para os gerentes, os funcionários e a organização para estabelecerem limites entre as conexões pessoais e profissionais no uso dessas ferramentas tecnológicas (ZHAO e KEMP, 2012).

Outro motivo pelo qual o emprego das MS é menos frequente e menos estudado pode estar relacionado com as estratégias e a forma como a organização trata e a maneira na qual são investigadas as questões sobre aprendizagem. Decerto, não se cogita que as MS possam ser estudadas e utilizadas de maneira formal e informal, integradas a ambientes e processos de aprendizagem nos locais de trabalho, "misturando informações e recursos de aprendizagem, 
hibridização de conhecimentos e ampliação do contexto de aprendizagem" (MANCA e RANIERI, 2016, p.1). Não obstante, os usos da tecnologia para a transferência de conhecimento, inclusive interorganizacional, possibilitam entrelaçar o conhecer e o fazer (GHERARDI, 2011).

Na perspectiva sociológica, a AO é vista como inerente e integrada ao cotidiano dos indivíduos, produzida em um processo dinâmico, a partir das interações entre pessoas e entre pessoas e objetos, em contextos específicos e situados. Esta perspectiva, que orienta este artigo, favorece o emprego da prática nas pesquisas sobre a aprendizagem em organizações por meio das mídias sociais. A prática possibilita a compreensão de diversos aspectos da realidade fenomênica organizacional - estratégia, tecnologia, aprendizagem -, na qual rotinas de comportamento compartilhadas interconectam pessoas e materiais pertencentes a um determinado contexto (GEHARDI, 2014a, 2014b; RECKWITZ, 2002; SCHATZKI, 2005).

Em se tratando de aprendizagem, "duas orientações são aparentes: uma que considera as práticas como objeto de análise empírica (o local de aprendizagem e conhecimento) e outra que assume a prática como epistemologia" (GHERARDI, 2011, p.43). Nessa direção, os modos de enquadramento propostos por Orlikowski (2010) preenchem uma lacuna. Para a autora, a noção da prática está no enquadramento e no planejamento da pesquisa o que proporciona diferentes abordagens e implicações sobre como esses estudos são realizados e compreendidos (ORLIKOWSKI, 2010).

Nesse sentido, é necessária uma reconsideração explícita das premissas paradigmáticas ao engajar-se com a prática na pesquisa (ORLIKOWSKI, 2010). Em razão da inexistência de uma teoria da prática abrangente e sistemática, igualmente de uma teoria da aprendizagem organizacional (NOGUEIRA e ODELIUS, 2015) e uma das mídias sociais (OUIRDI et al., 2014), os pesquisadores necessitam explicitar os conceitos que orientam o fenômeno estudado, os paradigmas, a epistemologia e a ontologia adotadas. A investigação deve ser realizada sob múltiplos níveis, pois o processo ocorre em nível individual e transcende o grupo e a organização.

Neste artigo, buscou-se examinar como a literatura sobre os modos de engajar a prática na pesquisa propostos por Orlikowski (2010) pode contribuir para a compreensão e a redução das lacunas existentes nos campos que investigam o fenômeno do uso das mídias sociais na aprendizagem em organizações (SCHEIN, 2014). O artigo está estruturado em cinco itens, incluída esta introdução. A seguir, discute-se as perspectivas adotadas na pesquisa sobre $A O$, destacando a perspectiva sociológica adotada no enquadramento da prática. Em igual direção, no terceiro item discorre-se sobre a estrutura interpretativa que viabiliza investigar como as MS contribuem para a $\mathrm{AO}$. $\mathrm{Na}$ sequência, são apresentadas as maneiras de engajar-se com a prática na pesquisa propostas por Orlikowski (2010). Na última sessão, têm-se as considerações finais, as contribuições e propostas para pesquisas futuras.

\section{DE QUE APRENDIZAGEM EM ORGANIZAÇÕES ESTÁ SE FALANDO?}

As pesquisas sobre $\mathrm{AO}$ são realizadas sob diversas perspectivas e abordagens. Não há um consenso sobre a natureza, o conceito, a tipologia e uma classificação de $A O$, sendo essa ausência, o ponto de unanimidade nesse campo (NOGUEIRA e ODELIUS, 2015; ANTONELLO e AZEVEDO, 2011). As diferentes posições ontológicas e epistemológicas produzem diferentes relatos de um mesmo objeto de estudo, e podem ser claramente observadas nos esforços realizados para tipificar essas posições distintas e nas revisões de literatura elaboradas nessa área de estudo (ANTONELLO e GODOY, 2011). 
Em 1983, Shrivastava (apud ANTONELLO e AZEVEDO, 2011) apontava essas diversas posições teóricas e conceitos empregados para descrever a $\mathrm{AO}$, que acabaram por motivá-lo a sintetizá-las em quatro perspectivas. Na compreensão da AO como adaptação estavam os estudos nos quais as organizações, através da aprendizagem, poderiam controlar as mudanças ambientais mediante a previsão ou a prevenção. Sob a ótica da AO como compartilhamento de pressupostos, as organizações aprendem a partir dos seus atores que aprendem a partir dessas organizações. Na perspectiva da AO como desenvolvimento de conhecimento sobre relações ação-resultado, a aprendizagem é um processo no qual o conhecimento é comunicável entre os atores da organização, tem validade consensual e está integrado nos procedimentos de trabalho. Essa interpretação deu força aos estudos da Gestão do Conhecimento da mesma maneira que a perspectiva da AO concebida como efeitos da experiência institucionalizada. Nessa concepção, estão os estudos fundamentados no pressuposto de que a experiência obtida na repetição das atividades produz melhor conhecimento e antecipação do ambiente, o que possibilita à organização lidar mais efetivamente com esse ambiente.

As quatro perspectivas apontadas por Shrivastava, apesar das diferenças entre si, tratavam a aprendizagem e o conhecimento como algo a ser assimilado (voluntária ou involuntariamente), transmitido, utilizado e armazenado, o que permitiria às organizações a promoção e o gerenciamento da aprendizagem. $O$ foco dessas perspectivas estaria na melhoria centrada em resultados, sendo a AO "uma necessidade da organização para o desenvolvimento da eficiência" (ANTONELLO e AZEVEDO, 2011, p.95). Essas perspectivas psicologicamente dirigidas estão centradas na cognição, na qual "o foco principal está na aquisição de conhecimentos explícitos e abstratos que passarão a fazer parte das atividades e rotinas organizacionais" (REATTO, 2014, p.38).

Os estudos que se valem das teorias de aprendizagem psicológica são examinados e revistos ao longo de dois contínuos por Shipton e DeFillippi (2011), nos quais é possível perceber que a aprendizagem também pode ser produzida e reproduzida nas relações sociais, conforme se verifica na Figura 1 . No primeiro contínuo, estão as teorias em que o aprendizado é suscetível ao controle e à direção, em oposição ao desdobramento natural no local de trabalho. No segundo, examina-se as distinções nas quais os indivíduos, em oposição aos grupos, foram tomados como ponto focal de investigação. Os autores afirmam que "a ênfase nos quatro quadrantes parece ter sido na modelagem cognitiva baseada na teorização no nível individual, desenvolvida para aplicabilidade no nível da organização ou, alternativamente, na exploração de como a aprendizagem surge informalmente, em um ambiente coletivo" (SHIPTON e DEFILLIPPI, 2011, p.78). Essa abordagem vai ao encontro das discussões de Maier, Prange e Von Rosentiel (2001) apresentadas por Antonello e Godoy (2011) ao tratarem da aprendizagem organizacional na perspectiva psicológica.

Figura 1: Framework de quatro quadrantes

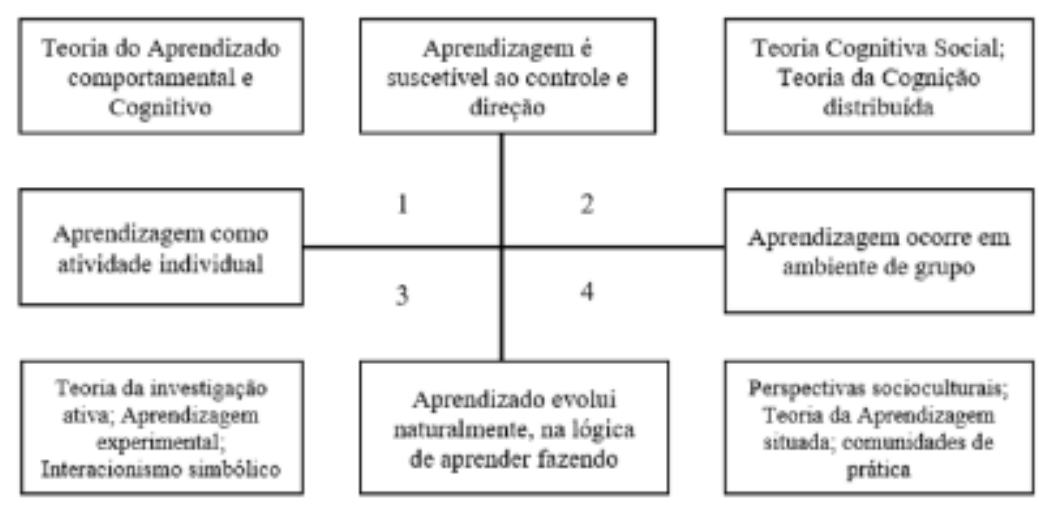

Fonte: Shipton e DeFillippi (2011, p.69) 
Mesmo considerando que, na concepção psicológica encontra-se a perspectiva da construção social, na qual a aprendizagem é socialmente construída e fundamentada em situações concretas, para Bispo (2011, p.32) o desafio está em como avançar na compreensão do fenômeno da aprendizagem no âmbito das coletividades, "sem necessariamente adotar uma perspectiva cognitiva-psicológica". Nesta direção, a perspectiva sociológica possibilita esse avanço, entendendo a aprendizagem enquanto fenômeno social e cultural, que implica em ações situadas no tempo, significando um meio de ser no mundo social (GHERARDI, 2011; 2014b).

Um separador importante entre as perspectivas de aprendizagem individual e social é a ênfase em aprender como aquisição de habilidades e conhecimento versus aprendizagem como englobando o desenvolvimento de identidades e socialização para o trabalho organizacional e para a vida (BRANDI e ELKJAER, 2011). A Teoria da Aprendizagem Social (TAS) na literatura sobre AO surge como uma crítica à perspectiva individual que, segundo Brandi e Elkjaer (2011), negligencia a dimensão ontológica da aprendizagem. "Na TAS, a dimensão epistemológica é muito mais do que aquisição de conhecimento, é prática, e envolve o desenvolvimento do ser humano como indivíduo social, incluindo assim a dimensão ontológica, inexistente na abordagem individual” (REATTO, 2014, p.39). A aprendizagem se dá pela interação do indivíduo podendo acontecer em qualquer lugar, a partir das experiências cotidianas e da participação e da interação nos processos sociais. Mais do que transferência, a aprendizagem é situada nos processos coletivos e na prática social do indivíduo na organização.

Mesmo assumindo que o indivíduo aprende por meio da trajetória da sua participação em uma organização específica, Elkjaer (2004) entendeu que a TAS não possibilitava unir conceitualmente a dimensão ontológica à epistemológica. A partir do pragmatismo, a autora procura enfatizar a impossibilidade de separar o indivíduo do social, do contexto e/ou da organização, focalizando o desenvolvimento da experiência humana como processos abrangentes de aquisição de conhecimento e de ser e se tornar parte do mundo. A contribuição mais benéfica do pragmatismo para a aprendizagem organizacional é, no entanto, a noção de investigação, que fornece um método no qual o pensamento é considerado uma ferramenta, uma maneira de definir problemas, e a reflexão é incluída como forma de compartilhar o resultado da aprendizagem, sem que se perca "a capacidade individual de investigar e decretar novas experiências organizacionais nos processos de aprendizagem organizacional" (BRANDI e ELKJAER, 2011, p.35).

A essência da aplicação de uma teoria do aprendizado social é que não é possível trabalhar com indivíduos típicos ideais que aprendem mudando seus modos de pensar (BRANDI e ELKJAER, 2011). Organizações consistem em pessoas reais, cada uma com suas próprias experiências, história e esperanças para o futuro. Isso compõe o contexto organizacional junto com a prática de trabalho específica, os artefatos, as regras e regulamentos organizacionais. E é desse ponto de partida que a aprendizagem organizacional começa a ocorrer.

Na perspectiva sociológica também se encontram os estudos de Gherardi (2014b, 2014a, 2011), de Nicolini (2013), dentre outros, em uma concepção denominada aprendizagem baseada em prática. Para esses pesquisadores, a aprendizagem é algo que acontece no fazer, produzido e reproduzido nas relações sociais, e não na mente do indivíduo. Nessa ótica, a perspectiva sociológica representa a aprendizagem em organizações da qual este artigo trata.

A partir destas lentes teóricas, é razoável conceber que as mídias sociais podem contribuir tanto com o conteúdo e com o processo de aprendizagem quanto na relação do indivíduo com a organização. Nessa direção, discute-se na próxima seção, se e como as MS podem colaborar para a AO. 


\section{AS MÍDIAS SOCIAIS PODEM CONTRIBUIR PARA A APRENDIZAGEM EM ORGANIZAÇÕES?}

De modo igual ao que acontece com a caracterização da $\mathrm{AO}$, a mídia social vem sendo empregada como um conceito guarda-chuva, embora seja limitado o entendimento sobre sua definição (OUIRDI et al., 2014). Em diversas abordagens, presume-se que as MS possuam um significado pré-contido e transparente, de entendimento consensual e inquestionável (Primo, 2012) e por isso, não expresso. Os conceitos atribuídos às MS, em sua maioria, descrevem a aplicabilidade e os canais utilizados para transmissão das mensagens (OUIRDI et al., 2014) ou as tecnologias móveis e suas interfaces, tais como serviços da web e aplicativos on-line (KAPLAN e HAENLEIN, 2010).

A definição de Kaplan e Haenlein (2010, p.61), "mídias sociais são um grupo de aplicativos baseados na Internet que se assentam nos pilares ideológicos e tecnológicos da web 2.0 e que permitem a criação e a troca de conteúdo gerado pelo usuário", é das mais citadas em artigos que investigam esses aplicativos (OUIRDI et al., 2014). Essa definição adequa-se não só ao dominante paradigma de pesquisa positivista que trata as MS como artefato tecnológico, mas também ao paradigma interpretativista que considera as MS como tecnologias em prática, o que possibilita a comparabilidade entre os estudos.

É necessário destacar que, enquanto artefato tecnológico, as MS são entidades identificáveis, relativamente duráveis, um fenômeno fisicamente organizado no espaço-tempo, com propriedades materiais e culturais que transcendem a experiência de indivíduos e ambientes particulares (ORLIKOWSKI, 2000). Na qualidade de tecnologia em prática, o uso das MS envolve uma versão do artefato tecnológico que foi experimentada por diferentes atores e de diversas maneiras, dependendo do tempo ou da circunstância. Ou seja, é somente quando as MS são usadas em práticas sociais recorrentes que se pode dizer que suas propriedades tecnológicas se tornam constituídas pelos usuários como regras e recursos específicos que moldam sua ação (ORLIKOWSKI, 2000).

Apesar de não haver uma maneira sistemática de categorizar os diferentes aplicativos, alguns estudos apresentam formas de ordená-los e estruturá-los para identificar os desafios e as oportunidades no emprego dessas ferramentas tecnológicas. Kaplan e Haenlein (2010) sistematizaram uma classificação capaz de ser adotada para novos aplicativos surgidos a cada dia, buscando teorias do campo de pesquisa de mídias e da área de processos sociais que iluminassem o fenômeno das MS. Para analisar o elemento mídia das MS, os autores destacaram na Teoria da Presença Social (SHORT, WILLIAMS e CHRISTIE, 1976 apud KAPLAN e HAENLEIN, 2010) a interação (presença) pela mídia. A presença social é influenciada pela intimidade (interpessoal e mediada) e pelo imediatismo (assíncrono versus síncrono) do meio, e pode ser menor em encontros mediados (conversação telefônica) do que em encontros interpessoais (discussão face a face), e menor em comunicações assíncronas (e-mail) do que naquelas sincronizadas (chat ao vivo). Quanto maior a presença social, maior a influência social que os parceiros de comunicação têm sobre o comportamento do outro. A ideia de presença social foi relacionada ao conceito de riqueza da mídia (DAFT e LENGEL, 1986 apud KAPLAN e HAENLEIN, 2010), partindo-se do pressuposto de que o objetivo de qualquer comunicação é a resolução da ambiguidade e a redução da incerteza, sendo alguns meios mais eficazes que outros.

Ao elemento social das MS, os autores associaram a auto apresentação, referente à maneira como nos relacionamos e nos apresentamos ao mundo, muitas vezes tentando controlar as impressões formadas por outras pessoas sobre nós. Normalmente, a auto apresentação é feita através da auto divulgação: as pessoas revelam, consciente ou inconscientemente, informações pessoais consistentes com a imagem que gostariam de passar. O framework elaborado Kaplan e Haenlein (2010) que apresenta a relação entre os conceitos e suas gradações está disposto na Figura 2.

As MS introduzem mudanças substanciais e generalizadas que são desafiadoras, pois diversos métodos de gerenciamento estabelecidos não são adequados para lidar com essas tecnologias nas 
relações indivíduo-organização. Há uma ecologia rica, diversificada e ainda desconhecida de sites de MS, que variam em termos de escopo e funcionalidade. Kietzmann et al. (2011) desenvolveram um modelo, à semelhança de um favo de mel, usando sete blocos funcionais, com o intuito de contribuir para a compreensão dessa ecologia e de como as empresas podem desenvolver estratégias para monitorar, compreender e responder a diferentes atividades de MS.

Quadro 1: Classificação das mídias sociais por presença social / riqueza e auto apresentação / auto divulgação da mídia

\begin{tabular}{|l|l|l|l|}
\hline \multirow{2}{*}{$\begin{array}{c}\text { Auto } \\
\text { apresentação/ } \\
\text { Auto div ulgação }\end{array}$} & \multicolumn{1}{|c|}{ Baixa } & \multicolumn{1}{c|}{ Média } & \multicolumn{1}{c|}{ Alta } \\
\cline { 2 - 4 } & \multicolumn{1}{|c|}{ Presença social/ Riqueza de Mídia } \\
\hline Alta & Blogs & $\begin{array}{l}\text { Sites de Relacionamento } \\
\text { Social (Facebook) }\end{array}$ & $\begin{array}{l}\text { Mundos Virtuais (Second } \\
\text { Life) }\end{array}$ \\
\hline Baixa & $\begin{array}{l}\text { Projetos Colaborativos } \\
\text { (Wikipedia) }\end{array}$ & $\begin{array}{l}\text { Comunidades de conteúdo } \\
\text { (Youtube) }\end{array}$ & $\begin{array}{l}\text { Games Virtuais } \\
\text { (World of Warcraft) }\end{array}$ \\
\hline
\end{tabular}

Fonte: Kaplan e Haenlein (2010, p. 62).

O modelo foi desenvolvido com foco na relação empresa-cliente, mas pode ser aplicado na relação indivíduo-organização, uma vez que possibilita entender como as MS variam em termos de função e impacto e o desenvolvimento de "estratégias congruentes de mídia social baseadas no equilíbrio apropriado de componentes para sua comunidade" (KIETZMANN et al, 2011, p.250). Os sete blocos de construção - identidade, conversas, compartilhamento, presença, relacionamentos, reputação e grupos - são apresentados em dois favos, sendo o da esquerda com a descrição da funcionalidade e o da direita com as implicações, conforme se vê na Figura 2. No modelo, as diferentes atividades de MS são definidas pela extensão em que se concentram em alguns ou em todos esses blocos.

A adoção das MS envolve uma série de decisões práticas, como: qual aplicativo (Facebook, Twitter, Youtube, WhatsApp, dentre outros) deve ser usado, com que finalidade, que tipo de informações compartilhar, quem vai fornecer a informação, a quem se destina, o que será feito com as perguntas e respostas dos envolvidos. Essas escolhas envolvem questões de estratégia, questões tecnológicas, de estrutura organizacional e de gestão (MEIJER e THAENS, 2013).

Figura 2: Favo de mel da mídia social

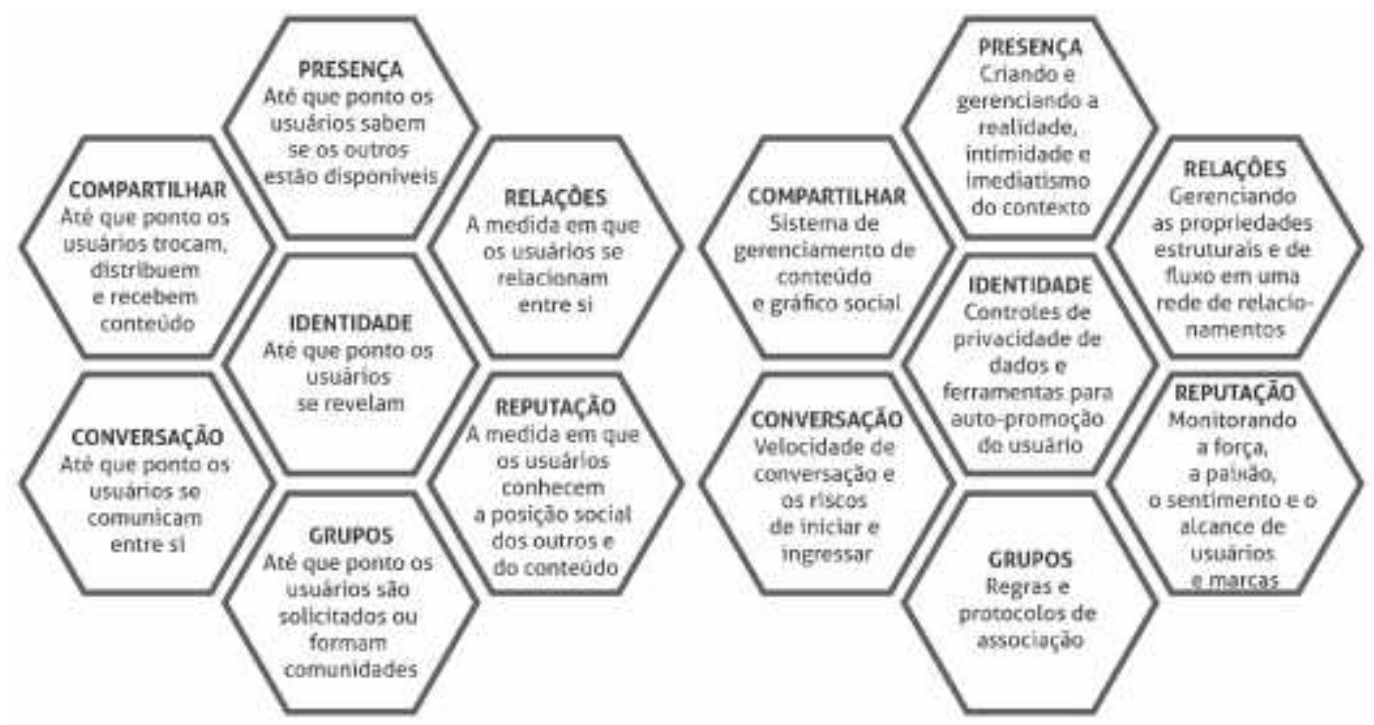

Fonte: Kietzmann et al. (2011, p. 243) 
Ao tratar das relações entre governo-cidadão, Mergel (2012) sumarizou quatro tipos de estratégias que podem ser empregadas em quatro perspectivas da relação governo-cidadão que, por analogia, podem ser pensadas sob a ótica da relação indivíduo-organização. O primeiro tipo de estratégia é uma "estratégia de empurrar" (push), na qual não há interação e a MS é usada para transmitir informações como uma mídia tradicional (MERGEL, 2012; MEIJER e THAENS, 2013). O segundo tipo é uma "estratégia de puxar" (pull), em que as MS são empregadas para atrair usuários para o site e tentar extrair deles informações por meio de um nível limitado de interação (MERGEL, 2012; MEIJER e THAENS, 2013). Um terceiro tipo é a "estratégia de rede" (networking) na qual as MS são utilizadas para interação, ou seja, em sua real função (MERGEL, 2012; MEIJER e THAENS, 2013). A estratégia de transação (transaction) representa um último estágio, no qual a prestação de serviços é conduzida através de aplicações de MS. As estratégias push e pull atendem a um leque mais restrito de objetivos e de interação, o que não acontece com as estratégias networking e transaction, que são mais descentralizadas e ligadas a uma variedade maior de objetivos e tarefas, o que possibilita uma maior interação (MEIJER e THAENS, 2013). Esses quatro tipos de estratégias estão descritos no Quadro 2.

Quadro 2: Estratégias para emprego das Mídias Sociais no setor público

\begin{tabular}{|l|l|l|}
\hline \multicolumn{1}{|c|}{ Tipo de estratégia } & \multicolumn{1}{|c|}{ Perspectiva das relações } & \multicolumn{1}{c|}{ Papel das mídias sociais } \\
\hline Estratégia de empurrar ( Push) & $\begin{array}{l}\text { Cidadãos como audiência para } \\
\text { informação governamental }\end{array}$ & $\begin{array}{l}\text { Mídia social como canal de } \\
\text { transmissão }\end{array}$ \\
\hline Estratégia de puxar ( Pull) & $\begin{array}{l}\text { Cidadãos como sensores para o } \\
\text { governo }\end{array}$ & $\begin{array}{l}\text { Mídia social como canal de } \\
\text { entrada do cidadão }\end{array}$ \\
\hline Estratégia de Rede ( Networking ) & $\begin{array}{l}\text { Cidadãos como coprodutores de } \\
\text { políticas governamentais }\end{array}$ & Mídia social como canal interativo \\
\hline $\begin{array}{l}\text { Estratégia transacional } \\
\text { (Transaction ) }\end{array}$ & $\begin{array}{l}\text { Cidadãos como parceiros de } \\
\text { negócios do governo }\end{array}$ & $\begin{array}{l}\text { Mídia social como ambiente } \\
\text { transacional }\end{array}$ \\
\hline
\end{tabular}

Fonte: Meijer e Thaens (2013, p. 344).

As funcionalidades das MS que possibilitam a interação por meio do compartilhamento de conteúdo têm sido pouco utilizadas para aprendizagem e geração de conhecimento nos setores privado e público (SCHEIN, 2014). Pensando na perspectiva da tecnologia em uso, as MS podem contribuir para a aprendizagem em organizações, uma vez que os indivíduos aprendem na interação dentro dos sistemas sociais.

Nessa lógica, é possível assegurar: i) a importância da interação por meio de conteúdo compartilhado para compreender o emprego dessas tecnologias "não como incorporadas em determinados artefatos tecnológicos, mas como são adotadas pelas práticas sociais recorrentes de uma comunidade de usuários" (ORLIKOWSKI, 2000, p.405); ii) a possibilidade de geração de conhecimento que não seja somente individual e cognitivo, mas um processo coletivo e compartilhado, propiciado pela interconectividade das MS (GEHARDI, 2014a, 2014b); e, iii) a comparabilidade com outras pesquisas dos campos da prática, tecnologias em uso e aprendizagem.

Assumindo que o saber e o fazer podem ser conectados pela prática (GHERARDI, 2014b), é lícito considerar que há uma racionalidade prática enraizada nos detalhes concretos da vida cotidiana que evidencia a natureza e o papel central que a prática desempenha no mundo social. É nessa ótica que se 
apresentam, na próxima seção, as contribuições que a prática pode oferecer aos pesquisadores envolvidos com estudos sobre mídias sociais e suas aplicações na aprendizagem em organizações.

\section{COMO A PRÁTICA PODE CONTRIBUIR PARA A COMPREENSÃO DO FENÔMENO DO USO DAS MÍDIAS SOCIAIS NA APRENDIZAGEM EM ORGANIZAÇÕES?}

A concepção de prática como uma epistemologia pode ser mais bem compreendida a partir da distinção feita entre as teorias da ação e da prática (GHERARDI, 2014a). Enquanto as primeiras priorizam a intencionalidade dos atores, da qual advém a ação com sentido, tal como em Weber e Parsons, as últimas localizam a origem dos padrões significativos na forma como o comportamento é enagido, desempenhado ou produzido, tal como em Mead, Schutz, Garfinkel e Giddens. Assim, enquanto as teorias da ação começam no indivíduo e na sua intencionalidade na busca de cursos de ação, as teorias da prática veem as ações como realizando-se ou acontecendo, desempenhadas por meio de uma rede de conexões em ação na qual a relacionalidade entre o mundo social e a materialidade pode ser investigada.

Cinco características particularizam as teorias da prática (NICOLINI, 2013). Primeiramente, essas abordagens enfatizam a importância da atividade e trabalham na criação e perpetuação de todos os aspectos da vida social, em uma perspectiva processual e relacional. Em segundo lugar, as práticas são concebidas como atividades corporais rotineiras tornadas possíveis pela contribuição ativa de uma variedade de recursos materiais. Em terceiro, essas teorias criam um espaço específico para agências e agentes individuais. Em quarto lugar, a percepção sobre conhecimento, significado e discurso é transformada. Em uma perspectiva prática, o conhecimento é um meio de saber compartilhado com os outros, um conjunto de métodos práticos adquiridos através da aprendizagem, inscritos em objetos, incorporados e apenas parcialmente articulados no discurso. Tornar-se parte de uma prática existente envolve não só aprender como agir e como falar (e o que dizer), mas também como sentir, o que esperar e o que as coisas significam. As práticas discursivas precisam ser consideradas lado a lado com outras formas de atividade social e material. Por fim, em último lugar, reafirma a centralidade dos interesses e, portanto, coloca ênfase na importância do poder, do conflito e da política como elementos constitutivos da realidade social.

Entretanto, o que se quer dizer quando se fala em prática? A resposta a essa questão não é elementar. Além de ser um termo de uso comum, modo recorrente de fazer as coisas, os estudos baseados em prática abrangem uma pluralidade de interesses e de metodologias e métodos de pesquisa. Também os pesquisadores teorizam a partir de uma noção de prática ou de um constructo que estabelecem em seus trabalhos, gerando uma polissemia (GHERARDI, 2014a). Um traço comum entre os constructos estabelecidos para a prática reside na conexão entre a ação individual e o que é normativo ou institucionalizado, superando a discussão entre agência e estrutura, na qual não o indivíduo, mas a relacionalidade, a ação e a interação passam a ocupar o centro da análise social. "As tentativas de identificar uma "teoria da prática" abrangente e sistemática [Friedmann, 1987, p. 186] deram lugar, em grande parte, à sugestão de que o conceito de prática é mais efetivamente usado como uma forma de enquadrar e orientar a pesquisa (Schatzki, 2001, p. 4)" (ORLIKOWSKI e SCOTT, 2008, p. 462).

Assim, engajar-se com a prática na pesquisa implica uma reconsideração explícita das premissas paradigmáticas. Orlikowski (2010) destaca três modos de envolver a prática na pesquisa gerencial empregados pelos pesquisadores, e as diferenças identificadas surgem como resultado de focos distintos e da lógica da investigação: "um enfoque empírico sobre como as pessoas agem em 
contextos organizacionais; um foco teórico na compreensão das relações entre as ações das pessoas e as estruturas da vida social; e um foco filosófico no papel constitutivo das práticas na produção da realidade social" (FELDMAN e ORLIKOWSKI, 2011, p.1240), como pode ser visto no Quadro 3.

O primeiro modo enfatiza a prática como um fenômeno, reforçando a ideia de que o mais importante na pesquisa organizacional é entender o que acontece "na prática", em oposição ao que é derivado ou esperado da "teoria". O segundo modo assume a prática como uma perspectiva, considerando a articulação de uma teoria centrada na prática sobre algum aspecto das organizações. Assim, a atividade cotidiana se torna o objeto da análise. Finalmente, o terceiro modo destaca a noção de prática como uma filosofia, assumindo o compromisso com uma ontologia que postula a prática como constitutiva de toda a realidade social, incluindo a realidade organizacional (ORLIKOWSKI, 2010).

Os três modos de engajar a prática na pesquisa não são mutuamente excludentes, mas podem ser entendidos como pressupostos divergentes sobre o poder da prática de produzir o mundo. A consequência é que esses pressupostos têm implicações diferentes sobre como os estudos de prática são compreendidos e realizados. "Pesquisadores envolvidos em estudos sobre a prática como um fenômeno podem escolher fazê-lo sem empregar uma teoria prática ou uma ontologia prática" (ORLIKOWSKI, 2010, p. 23 e 24). No entanto, os que se baseiam na prática como perspectiva seguramente se concentrarão em alguma forma de fenômeno de prática e o farão através de uma lente teórica da prática, mas não precisam incorporar uma ontologia de prática. Pesquisadores que se baseiam na prática como filosofia acreditam na primazia das práticas em constituir a vida social e, portanto, necessariamente se engajam com a prática através dos três modos: filosoficamente, teoricamente (prática como perspectiva) e empiricamente (prática como um fenômeno) (ORLIKOWSKI, 2010).

Estudos com um enfoque empírico, tratando a prática como fenômeno, podem reconhecer a centralidade das ações das pessoas para os resultados organizacionais e a importância das práticas nas organizações enfatizando a importância da agência humana na produção de realidade organizacional sem levar em conta o aparelho teórico ou filosófico de uma lente da prática (FELDMAN e ORLIKOWSKI, 2011). Essas investigações buscam "responder ao 'o quê' de uma lente da prática, ou seja, um foco na atividade cotidiana de organização, tanto na sua rotina quanto nas formas improvisadas" (FELDMAN e ORLIKOWSKI, 2011, p.1240).

Quadro 3: Modos de engajar a prática na pesquisa

\begin{tabular}{|c|c|c|c|}
\hline \multicolumn{4}{|c|}{ Prática na pesquisa } \\
\hline $\begin{array}{l}\text { Modos de } \\
\text { engajamento }\end{array}$ & Fundamento & Enfoque & Implicações para a pesquisa \\
\hline Fenômeno & $\begin{array}{l}\text { Entender o que } \\
\text { acontece na prática. } \\
\text { Visa preencher a } \\
\text { lacuna entre o } \\
\text { conhecimento } \\
\text { cientifico e a } \\
\text { realidade vivida. } \\
\text { As práticas são } \\
\text { importantes e } \\
\text { precisam ser } \\
\text { empiricamente } \\
\text { engajadas para } \\
\text { entender/melhorar a } \\
\text { realidade. }\end{array}$ & $\begin{array}{l}\text { Foco nas realidades } \\
\text { cotidianas, conforme } \\
\text { elas surgem na } \\
\text { prática. } \\
\text { Ajudar a criar e a } \\
\text { implementar } \\
\text { mudanças práticas e } \\
\text { mais substantivas. } \\
\text { Formas situadas de } \\
\text { ação nunca podem } \\
\text { ser totalmente } \\
\text { especificadas a } \\
\text { priori. }\end{array}$ & $\begin{array}{l}\text { Envolvimento empírico. } \\
\text { Independe de uma teoria ou } \\
\text { ontologia da prática. } \\
\text { Objetivo: entender o que os atores } \\
\text { fazem diariamente no trabalho. } \\
\text { Foco nos detalhes dos feitos } \\
\text { cotidianos. } \\
\text { Método etnográfico com grupos } \\
\text { sociais especificos buscando } \\
\text { entender como eles fazem o que } \\
\text { fazem. } \\
\text { Técnica: observação participante } \\
\text { imersiva e } \\
\text { pesquisa-ação. } \\
\text { Resultados são relevantes para os } \\
\text { praticantes e os contextos estudados. }\end{array}$ \\
\hline
\end{tabular}




\begin{tabular}{|c|c|c|c|}
\hline \multicolumn{4}{|c|}{ Prática na pesquisa } \\
\hline $\begin{array}{l}\text { Modos de } \\
\text { engajamento }\end{array}$ & Fundamento & Enfoque & Implicações para a pesquisa \\
\hline Perspectiva & $\begin{array}{l}\text { Emprego de teorias da } \\
\text { prática - lente para } \\
\text { estudar fenômenos } \\
\text { especificos. } \\
\text { É através da natureza } \\
\text { situada e recorrente da } \\
\text { atividade cotidiana } \\
\text { que as consequências } \\
\text { estruturais são } \\
\text { produzidas, } \\
\text { reforçadas ou } \\
\text { mudadas. }\end{array}$ & $\begin{array}{l}\text { As práticas moldam } \\
\text { a realidade. } \\
\text { Articulação de uma } \\
\text { teoria centrada na } \\
\text { prática sob algum } \\
\text { aspecto da } \\
\text { organização. } \\
\text { Compreensão } \\
\text { teoricamente } \\
\text { fundamentada na } \\
\text { interação recursiva } \\
\text { entre pessoas, } \\
\text { atividades, artefatos } \\
\text { e contextos, para } \\
\text { abordar fenômenos } \\
\text { organizacionais } \\
\text { relacionais, } \\
\text { dinâmicos e } \\
\text { emergentes. }\end{array}$ & $\begin{array}{l}\text { Empregam uma lente teórica da } \\
\text { prática, podendo năo incorporar uma } \\
\text { ontologia da prática } \\
\text { A apropriação de uma lente prática } \\
\text { teórica requer que os pesquisadores } \\
\text { atentem para certos aspectos dos } \\
\text { fenômenos sociais, variando as } \\
\text { especificidades pela teoria da prática } \\
\text { particular adotada. }\end{array}$ \\
\hline Filosofia & $\begin{array}{l}\text { Toda realidade social } \\
\text { ê entendida como } \\
\text { constituida em e } \\
\text { através de práticas. }\end{array}$ & $\begin{array}{l}\text { Compromisso com a } \\
\text { primazia ontológica } \\
\text { da prática na vida } \\
\text { social. }\end{array}$ & $\begin{array}{l}\text { Envolvimento filosófico, teórico e } \\
\text { empirico com a prática na pesquisa. } \\
\text { Entrelaçamento ontológico no qual } \\
\text { não há entidades independentemente } \\
\text { existentes com caracteristicas } \\
\text { inerentes - reconfiguraçōes } \\
\text { sociomateriais - práticas } \\
\text { contingentes. } \\
\text { O engajamento da prática na } \\
\text { pesquisa é performativo. }\end{array}$ \\
\hline
\end{tabular}

Fonte: Elaborado pela autora a partir de Orlikowski (2010) e Feldman e Orlikowski (2011)

O uso das mídias sociais na aprendizagem analisado enquanto perspectiva tem em conta objetivamente a instrumentalidade da teoria da prática. Apesar desses estudos incluírem "um foco na atividade cotidiana, estão criticamente preocupados com uma explicação específica para essa atividade" (FELDMAN e ORLIKOWSKI, 2011, p.1240), buscando responder ao "como" de uma lente da prática. Essas pesquisas procuram articular "determinadas relações teóricas que explicam a dinâmica da atividade cotidiana, como elas são geradas e como elas operam em diferentes contextos e ao longo do tempo" (FELDMAN e ORLIKOWSKI, 2011, p.1240). Esses estudos poderiam se valer, inclusive, de duas ou três lentes teóricas. Uma, a partir dos estudos que desenvolveram as bases do que é conhecido hoje como teoria da prática, elaboradas por teóricos como Bourdieu, Giddens, Schutz, Garfinkel, Lave, Latour, Savigny e Schatzki. E outra, por teóricos da aprendizagem em organizações como Brandi e Elkjaer, Lave, Wenger, Brown e Duguid. Ou outra, a partir de estudos como a classificação das mídias sociais propostas por Kaplan e Haenlein, o modelo de Kietzmann et al ou os tipos de estratégias propostos por Meijer e Thaens.

Cita-se como exemplo, a articulação da Teoria de Aprendizagem Social (BRANDI e ELKJAER, 2011) com a classificação das MS proposta por Kaplan e Haenlein (2010). Essa convergência possibilita uma análise do processo de aprendizagem em organizações com foco na participação e interação frente ao emprego de MS tais como blogs, sites de relacionamento social, projetos colaborativos, comunidades de conteúdo, mundos virtuais e games virtuais. A investigação sobre a contribuição das MS ao 
processo de AO pode ser realizada a partir dos elementos da Teoria da Presença Social (SHORT, WILLIAMS e CHRISTIE, 1976 apud KAPLAN e HAENLEIN, 2010) e da auto apresentação.

Duas ou três abordagens, consideradas em conjunto, representam uma base teórica multifacetada que pode contribuir tanto para a agenda dos estudos baseados em prática quanto para o campo da aprendizagem em organizações e do emprego das mídias sociais, proporcionando: i) percepções distintas sobre como os atores constroem na prática os vínculos entre suas atividades diárias e entre as macroestruturas de suas organizações nos processos de $\mathrm{AO}$ a partir do uso das MS; ii) conceitos teóricos úteis para compreender o que fazem os atores em prática nos processos de $A O$; e, iii) ferramentas para lidar com a materialidade do processo do emprego das MS; (DENIS, LANGLEY e ROULEAU, 2007). No entanto, é fundamental atentar que "trabalhar com as ideias teóricas específicas dos teóricos da prática exige que os pesquisadores se envolvam com a lógica central de como as práticas são produzidas, reforçadas e alteradas, e com as consequências pretendidas e não intencionais" (FELDMAN e ORLIKOWSKI, 2011, p.1241).

O uso das mídias sociais na aprendizagem analisado enquanto filosofia resulta no argumento de que a realidade social é fundamentalmente constituída de práticas. "Ou seja, em vez de ver o mundo social como externo aos agentes humanos ou como socialmente construído por eles, essa abordagem vê o mundo social trazido à existência por meio da atividade cotidiana" (FELDMAN e ORLIKOWSKI, 2011, p.1241), procurando expor o "porquê" de uma lente da prática, no qual as práticas são entendidas como os blocos de construção primários da realidade social.

Alguns pesquisadores usam uma ontologia prática para questionar o status do fenômeno que estão estudando (por exemplo, Gherardi, 2006; Lave, 1988). Eles fazem isso assumindo a primazia ontológica da prática - ou seja, que as práticas são fundamentais para a produção da realidade social - um aspecto central de sua agenda de pesquisa (por exemplo, sobre aprendizado $e$ conhecimento) e depois a usam para reconsiderar e especificar novamente o fenômeno de interesse (por exemplo, em termos de ação coletiva e cognição na prática). (FELDMAN e ORLIKOWSKI, 2011, p.1242).

O emprego da prática na pesquisa sobre o uso das MS na AO possibilita aos pesquisadores "criarem seus próprios métodos na condução de seus estudos, assim como atenção a maneira de empregar métodos conhecidos de pesquisa para realizar estudos baseados em práticas" (BISPO, 2015, p.310). Neste artigo, reconhece-se que é na direção proposta por Orlikowski (2010), que a prática pode ser com mais acerto engajada à pesquisa e pode contribuir para compreensão do fenômeno do uso das mídias sociais na aprendizagem em organizações.

\section{CONSIDERAÇÕES FINAIS}

Este artigo avançou no debate em construção sobre o uso das mídias sociais na aprendizagem em organizações descrevendo como a prática pode contribuir para uma melhor compreensão desse fenômeno. Para isto, inicialmente, buscou-se identificar as perspectivas adotadas na pesquisa sobre AO. Nesse sentido, constatou-se que há uma predominância de estudos que privilegiam as 
abordagens cognitiva-psicológicas. No entanto, é possível perceber que a aprendizagem também pode ser produzida e reproduzida nas relações sociais, para além do tratamento à aprendizagem como algo a ser assimilado, transmitido, utilizado e armazenado. Ou seja, evolui-se da aprendizagem suscetível ao controle e direção para a lógica do aprender fazendo. Assim, na perspectiva sociológica é possível analisar o processo de aprendizagem em organizações enquanto prática, compreendendo a aprendizagem enquanto fenômeno social e cultural.

Em continuidade, examinou-se como as mídias sociais podem contribuir com a AO. Há uma predominância de pesquisas positivistas no campo das mídias sociais, que as consideram como artefato tecnológico. Se o pesquisador está empregando a prática para analisar a aprendizagem em uma perspectiva sociológica, as MS devem ser investigadas enquanto tecnologia em uso, para que se mantenha o nexo entre a estrutura da pesquisa, o objeto e o referencial teórico. Dessa maneira, para se investigar o uso dessas ferramentas tecnológicas sob o enfoque da prática é necessário fazê-lo enquanto um artefato que foi experimentado por diferentes atores e de diversos modos, tendo como unidade de análise a prática e não a tecnologia em si ou os seus usuários.

Em seguida, apresenta-se as três maneiras de se engajar com a prática na pesquisa propostas por Orlikowski (2010). Ao enfocar a prática como um fenômeno, o pesquisador se engaja com os feitos cotidianos da organização. Enquanto uma perspectiva, o pesquisador examina e explica o fenômeno articulado com as teorias da prática. Nesse sentido, este artigo procura estimular estudos que articulem teorias da prática com perspectivas sociológicas sobre a aprendizagem em organizações e o uso das mídias sociais, associando os domínios substantivos e teóricos sem desconsiderar as opções epistemológicas e ontológicas adotadas na pesquisa. Não são apresentados um número expressivo de exemplos nessa direção, o que pode ser considerado uma limitação deste estudo. O pesquisador ao focalizar a prática como filosofia, explicita que a compreende como constitutiva da realidade. Assim, os pressupostos filosóficos e a estrutura interpretativa empregados na pesquisa têm implicações diferentes sobre como os estudos de prática são compreendidos e realizados.

Acredita-se que a discussão realizada nesse artigo possa cooperar com o debate em construção sobre o fenômeno do uso das mídias sociais no processo de aprendizagem em organizações. A crescente preocupação em aprender e aplicar a prática em pesquisas empíricas, não é, como alguns ironizam apenas mais um dos modismos nas ciências sociais. Pelo contrário, como se procurou demonstrar aqui, é possível se valer da prática com rigor e consistência na condução da pesquisa dentro das premissas científicas. 


\section{REFERÊNCIAS}

ANTONELLO, Cláudia S.; AZEVEDO, Débora. Aprendizagem organizacional explorando o terreno das teorias culturais e das teorias baseadas em práticas. Aprendizagem organizacional no Brasil. Porto Alegre: Artmed, 2011.

ANTONELLO, Cláudia S.; GODOY, Arilda S. Aprendizagem organizacional e as raízes de sua polissemia. Aprendizagem organizacional no Brasil, p. 31-50, 2011.

BISPO, M. D. S.. O processo de aprendizagem coletiva e o uso da tecnologia em agências de viagens: contribuições dos estudos baseados em prática e da etnometodologia. 2011.Tese de doutorado, Universidade Presbiteriana Mackenzie, São Paulo, SP, Brasil.

BRANDI, Ulrik; ELKJAER, Bente. Organizational learning viewed from a social learning perspective. Handbook of organizational learning and knowledge management, v. 2, p. 23-41, 2011.

DENIS, Jean-Louis; LANGLEY, Ann; ROULEAU, Linda. Strategizing in pluralistic contexts: Rethinking theoretical frames. Human relations, v. 60, n. 1, p. 179-215, 2007.

ELKJAER, Bente. Organizational learning: the 'third way'. Management learning, v. 35, n. 4, p. 419-434, 2004.

FELDMAN, Martha S.; ORLIKOWSKI, Wanda J. Theorizing practice and practicing theory. Organization science, $v$. 22, n. 5, p. 1240-1253, 2011.

GHERARDI, Silvia. O poder crítico das "lentes da prática". In: Administração e aprendizagem na prática. Elsevier Editora Ltda., 2014a. p. 43-57.

GHERARDI, Silvia. Conhecimento situado e ação situada: o que os estudos baseados em prática prometem?. In: Administração e aprendizagem na prática. Elsevier Editora Ltda., 2014b. p. 3-17.

GHERARDI, Silvia. Organizational learning: The sociology of practice. Handbook of organizational learning and knowledge management, v. 2, n. 1, p. 43-65, 2011.

KAPLAN, Andreas M.; HAENLEIN, Michael. Users of the world, unite! The challenges and opportunities of Social Media. Business horizons, v. 53, n. 1, p. 59-68, 2010.

KIETZMANN, Jan $\mathrm{H}$. et al. Social media? Get serious! Understanding the functional building blocks of social media. Business horizons, v. 54, n. 3, p. 241-251, 2011.

LEONARDI, Paul M.; HUYSMAN, Marleen; STEINFIELD, Charles. Enterprise social media: Definition, history, and prospects for the study of social technologies in organizations. Journal of Computer-Mediated Communication, $v$. 19, n. 1, p. 1-19, 2013. Disponível em: https://onlinelibrary.wiley.com/doi/full/10.1111/jcc4.12029 Acesso em: 01Ago2018

MANCA, Stefania; RANIERI, Maria. Is Facebook still a suitable technology-enhanced learning environment? An updated critical review of the literature from 2012 to 2015. Journal of Computer Assisted Learning, v. 32, n. 6, p. 503-528, 2016.

MEIJER, Albert; THAENS, Marcel. Social media strategies: Understanding the differences between North American police departments. Government information quarterly, v. 30, n. 4, p. 343-350, 2013. 
MERGEL, Ines. The social media innovation challenge in the public sector. Information Polity, v. 17, n. 3, 4, p. 281292, 2012.

NICOLINI, Davide. Practice theory, work, and organization: An introduction. OUP Oxford, 2012.

NISAR, Tahir M.; PRABHAKAR, Guru; STRAKOVA, Lubica. Social media information benefits, knowledge management and smart organizations. Journal of Business Research, v. 94, p. 264-272, 2019.

NOGUEIRA, Ronaldo Alves; ODELIUS, Catarina Cecília. Desafios da pesquisa em aprendizagem organizacional. Cadernos Ebape. BR, v. 13, n. 1, p. 83-102, 2015.

ORLIKOWSKI, Wanda J. Practice in research: phenomenon, perspective and philosophy. Cambridge handbook of strategy as practice, p. 23-33, 2010.

ORLIKOWSKI, Wanda J. Using technology and constituting structures: A practice lens for studying technology in organizations. Organization science, v. 11, n. 4, p. 404-428, 2000.

ORLIKOWSKI, Wanda J.; SCOTT, Susan V. 10 sociomateriality: challenging the separation of technology, work and organization. Academy of Management annals, v. 2, n. 1, p. 433-474, 2008.

OUIRDI, Mariam El et al. Social media conceptualization and taxonomy: A Lasswellian framework. Journal of Creative Communications, v. 9, n. 2, p. 107-126, 2014.

PRIMO, AleX. O QUE HÁ DE SOCIAL NAS MÍDIAS SOCIAIS? REFLEXÕES A PARTIR DA TEORIA ATOR-REDE//WHAT IS SOCIAL IN SOCIAL MEDIA? MUSINGS BASED ON ACTOR-NETWORK THEORY. Contemporânea, v. 10, n. 3, p. 618641, 2012.

REATTO, D. L. Os processos de aprendizagem informal no local de trabalho: um estudo com técnicosadministrativos numa faculdade pública estadual. 2014. Dissertação de Mestrado, Universidade Presbiteriana Mackenzie, São Paulo, SP, Brasil.

RECKWITZ, Andreas. Toward a theory of social practices: A development in culturalist theorizing. European journal of social theory, v. 5, n. 2, p. 243-263, 2002.

SCHATZKI, T. R. Introduction: practice theory. In: CETINA, K. K., SCHATZKI, T. R., \& VON SAVIGNY, E. (Eds.). The practice turn in contemporary theory. Routledge, 2005.

SCHEIN, Caroline. The value of integrating social media tools into organizational learning processes. 2014. Tese de Doutorado. Fielding Graduate University.

SHIPTON, Helen; DEFILLIPPI, Robert. Psychological perspectives in organizational learning: a four-quadrant approach. Handbook of organizational learning \& knowledge management, v. 2, p. 67-81, 2011.

SKEELS, Meredith M.; GRUDIN, Jonathan. When social networks cross boundaries: a case study of workplace use of facebook and linkedin. In: Proceedings of the ACM 2009 international conference on Supporting group work. 2009. p. 95-104.

SUBRAMANIAM, Niran; NANDHAKUMAR, Joe; BAPTISTA, João. Exploring social network interactions in enterprise systems: the role of virtual co-presence. Information Systems Journal, v. 23, n. 6, p. 475-499, 2013.

ZHAO, Fang; KEMP, Linzi J. Integrating Web 2.0-based informal learning with workplace training. Educational Media International, v. 49, n. 3, p. 231-245, 2012. 


\section{CERTIFICAÇÃO DE QUALIDADE COMO INOVAÇÃO NA GESTÃO DE SERVIÇOS DE SAÚDE: EXPERIÊNCIA DO CEARÁ.}

\author{
Flavianne Santos Soares Oliveira \\ Universidade Estadual do Ceará-UECE
}

Maria Ludimila Arruda Frota Rocha

Universidade Estadual do Ceará-UECE

\section{RESUMO}

O Ministério da Saúde e suas agências (ANVISA E ANS) têem demonstrado preocupação em aumentar a qualidade e a segurança dos serviços de saúde prestados no país. Em abril de 2013, o Governo Federal instituiu o Programa Nacional de Segurança do Paciente, objetivando qualificar o cuidado em saúde para todos os estabelecimentos de saúde do território nacional. Ainda no mesmo ano, a ANVISA publica a RDC no 36, através da qual, sinaliza a obrigatoriedade de a direção dos serviços de saúde constituírem seus Núcleos de Segurança do Paciente. Este trabalho propõe-se a apresentar a experiência da Secretaria da Saúde do Estado no processo de certificação de qualidade das unidades da rede, por meio de padrões internacionalmente reconhecidos, com destaque para
Lady Diana Arruda Mota

Universidade Estadual do Ceará-UECE a experiência inovadora da acreditação dos serviços odontológicos até então, inédito no país. Participaram deste projeto piloto 08 unidades: 04 Policlínicas de especialidades médicas e 05 centros de Especialidades Odontológicas, entre os anos de 2015 e 2016. Essa experiência colocou a saúde do Estado do Ceará em destaque no cenário nacional, tanto pelo resultado quanto pelo pioneirismo, tendo em vista a acreditação dos primeiros serviços de odontologia.

\section{Palavras-chave:}

Segurança do paciente, qualidade, acreditação.

\section{ABSTRACT}

The Ministry of Health and its agencies (ANVISA AND ANS) have been concerned with increasing the quality and safety of health services provided in the country. In April 2013, the Federal Government instituted the National Patient Safety Program, aiming to qualify health care for all health establishments in the national territory. Still in the same year, ANVISA publishes RDC $n$ o 36, through which it signals the obligation for the direction of the health services to constitute their Patient Safety Centers. This paper proposes to present the experience of the State Health Secretariat in the quality certification process of the units of the network, by means of internationally recognized standards, with emphasis on the innovative experience of accreditation of dental services until then, unprecedented in the country. . 08 units participated in this pilot project: 04 Polyclinics of medical specialties and 05 centers of Dental Specialties, between the years 2015 and 2016. This experience put the health of the State of Ceará in prominence in the national scenario, both for the result and for the pioneering spirit, having in view of the accreditation of the first dental services.

\section{Keywords:}

Patient safety, quality, accreditation 
INTRODUÇÃO

O contexto atual de gestão da saúde no país experimenta uma transformação. A insatisfação com os serviços de saúde lidera a lista dos clientes que ao passar dos anos estão cada vez mais exigentes e conscientes dos seus direitos. Na contramão disso, empresas e governos buscam soluções para reduzir os custos crescentes, melhorando a qualidade de seus serviços, alinhando as expectativas dos clientes e do mercado.

Entre os anos 2009 e 2016, o Estado do Ceará, com o objetivo de contribuir para a ampliação do acesso e da qualidade dos serviços de saúde especializados, promover a integração entre os distintos níveis de atenção e fortalecer a regionalização da saúde no Estado, firmou um contrato de empréstimo com o Banco Interamericano de Desenvolvimento (BID) para a execução do Programa de Expansão e Melhoria da Assistência Especializada do Estado do Ceará (PROEXMAES). O objetivo principal do PROEXMAES foi aà ampliação da oferta de serviços de saúde especializados nas 22 Regiões de Saúde. No âmbito do programa, foram construídos 21 Policlínicas Regionais, 16 Centros de Especialidades Odontológicas e 02 Hospitais Regionais. Além do investimento em infraestrutura, o programa visava o fortalecimento institucional da gestão da Secretaria da Saúde do Estado do Ceará (SESA) e a melhoria contínua da qualidade dos serviços de saúde, por meio do processo de acreditação dos serviços, dentre eles, a acreditação de serviços odontológicos, até então inédito no país.

Para a execução do Programa de Expansão e Melhoria da Assistência Especializada àa Saúde do Estado do Ceará (PROEXMAES), 2137/OB-BR, em sua primeira etapa (2009 a 2014), estava prevista a certificação de qualidade (acreditação) de 37 unidades construídas no âmbito do programa, sendo 16 Centros de Especialidades Odontológicas (CEO) e 21 Policlínicas.

A Acreditação é um método de avaliação e certificação que busca, por meio de padrões e requisitos previamente definidos, promover a qualidade e a segurança da assistência no setor de saúde. Para ser acreditada, a organização precisa comprovadamente atender aos padrões definidos pela ONA, reconhecidos internacionalmente (ONA, 2020).

O processo de acreditação é realizado de forma voluntária e reservada, sendo que o método de avaliação para Acreditação não tem caráter fiscalizatório e constitui, essencialmente, um programa de educação continuada das organizações prestadoras de serviços de saúde, revisto periodicamente para estimular a melhoria contínua. Por não ter caráter prescritivo, a metodologia de acreditação da ONA não traz recomendações específicas sobre ferramentas, técnicas, processos ou linhas metodológicas a serem seguidas pelas organizações que se submetem à avaliação (ONA,2020).

A metodologia ONA é a única no país que acredita em diferentes níveis: nível 1: acreditado, nível 2: acreditado pleno e nível 3: acreditado com excelência, o que permite auxiliar as organizações no desenvolvimento da segurança dos processos, na gestão integrada e na maturidade institucional (ONA, 2020).

De acordo com pesquisa realizada no site da Organização Nacional de Acreditação (ONA), até fevereiro de 2020, no Brasil, há 830 serviços de saúde acreditados, destes 97 (12\%) estão situados na 
Região Nordeste e 18 (2,16\%) no Estado do Ceará. O Ceará, no ranking da acreditação, é o segundo estado da região nordeste com mais instituições acreditadas. No cenário estadual, 67\% das instituições acreditadas pertencem àa rede pública de atenção à saúde, vinculadas àa Secretaria da Saúde do Estado (SESA).

A Acreditação dos CEO consiste em um produto inovador do PROEXMAES, tendo em vista que até 2012 não havia metodologia para certificação de serviços odontológicos no Brasil e que a SESA colaborou na construção da metodologia de avaliação para este serviço.

Durante a execução do programa, várias foram às tentativas em contratar os serviços de certificação e preparação para estas unidades. Fatores como: a especificidade do produto, limitação técnica quanto às modalidades de contratação aplicáveis, o escopo ampliado, a falta de interesse das empresas devido à dimensão e tempo de execução do projeto, ocasionando um preocupante atraso na execução.

Diante desse cenário, a Unidade de Gerenciamento de Projetos (UGP) da SESA realizou um diagnóstico desta situação a fim de buscar soluções e mitigar os riscos para o aperfeiçoamento e redefinição de escopo do projeto. E assim, considerando os entraves e lições aprendidas, no ano de 2015 a SESA delimitou um projeto piloto para a acreditação das unidades da rede, onde nele estariam contempladas as unidades com maturidade institucional para serem submetidas ao processo no prazo de até doze meses. Foram selecionadas nove unidades, sendo cinco Centros de Especialidades Odontológicas (CEO) e quatro Policlínicas.

A palavra qualidade tem um amplo significado e, por esse motivo, possibilita inúmeras interpretações. Para uns, representa a busca da satisfação do cliente. Para outros, a busca da excelência para todas as atividades de um processo. E ainda, pode significar adequação ao uso. Diante dessa premissa, o uso da palavra qualidade pode gerar certa confusão. "A confusão pode ser atribuída, em grande parte, ao sentido de subjetividade associado à qualidade e também ao uso genérico com que se emprega essa palavra a fim de representar coisas bastante distintas" (SILVA, K et al. 2015).

O trabalho teve como objetivo geral apresentar a experiência da Secretaria da Saúde do Estado do Ceará no processo de certificação de qualidade das unidades da Rede (Policlínicas e CEOs), por meio de padrões internacionalmente reconhecidos através do Manual da ONA.

\section{METODOLOGIA:}

Durante os anos de 2011 a 2013, a UGP da SESA conduziu paralelamente a instalação de 16 Núcleos Gerenciadores da Qualidade durante a implantação dessas unidades. Nesta ação foi realizada a sensibilização e preparação das equipes para um processo de certificação futuro, bem como a implantação de um modelo de gestão da qualidade. Durante essa etapa foram abordados os assuntos: Biossegurança, Gestão da Qualidade, Gestão Organizacional, Segurança do Paciente e etc.

A avaliação realizada para delimitação do projeto piloto, selecionou 09 unidades ambulatoriais (05 CEOS e 04 Policlínicas) para participação no projeto. Para tanto as unidades foram analisadas considerando os critérios de elegibilidade da metodologia que seria aplicada e aos critérios estabelecidos pela UGP para participação no projeto, sendo eles:

i) estar em funcionamento há pelo menos um ano, 
ii) possuir alvará de funcionamento, possuir licença sanitária e demais licenças pertinentes à natureza da atividade,

iii) possuir registro do médico responsável ou do dentista, no caso de serviços odontológicos,

iv) ter um profissional dedicado a operacionalização do Escritório da Qualidade.

As unidades ambulatoriais possuem o seguinte perfil: As Policlínicas possuem equipe multiprofissional com consultas de várias especialidades médicas prioritárias de: Cardiologia, Cirurgia Geral, Clínica Médica, Gastroenterologia, Gineco-Obstetrícia, Mastologia, Oftalmologia, Otorrinolaringologia, Traumato -Ortopedia e Urologia. Possuem também atendimentos em Fisioterapia / Terapia Ocupacional, Fonoaudiologia (equipado com cabine audiométrica), Assistência Farmacêutica e Consultório de Tratamento do Pé Diabético. A Unidade também conta com a estrutura física destinada aos Serviços de Apoio Diagnóstico e Terapêutico, equipada para a realização de RaiosX, Tomografia, Mamografia, Ultrassonografia, Endoscopia Digestiva Alta e Baixa, Ecocardiograma, Ergometria, Eletrocardiograma, Monitoramento Ambulatorial da Pressão Arterial (MAPA), Audiometria e coleta para Patologia Clínica.

O CEO (Centro de Especialidades Odontológicas) é uma unidade ambulatorial com 09 consultórios odontológicos integrados para o atendimento de Média Complexidade em Endodontia, Prótese, Periodontia e Ortodontia. Além disso,, possui outros dois outros consultórios que são exclusivos: um para Cirurgia Oral Menor e outro para Odontologia para Pacientes com Necessidades Especiais.

Dispõe ainda dos seguintes Serviços de Apoio Diagnóstico e Terapêutico: Radiologia periapical, interproximal e panorâmica (com captação digital), Biópsias e Próteses Dentárias.

É importante ressaltar que as Policlínicas e os CEOs possuem modelos de gestão consorciadas onde o custeio das unidades são rateados entre os municípios das Regiões de Saúde e o Estado. Além disso, os CEOs contam com recurso federal por participarem do Programa Brasil Sorridente. Esse modelo de gestão favorece a divisão das responsabilidades entre gestores municipais e possibilita ofertar serviços de saúde especializados àa população do interior do estado, racionalizando custos e otimizando resultados.

Definidas as unidades participantes, o projeto foi executado nas seguintes etapas, conforme exemplificado na figura 01:

- Assinatura de Termos de Compromisso: objetivando disciplinar a adesão ao processo, os gestores dos consórcios, os, diretores das nove unidades selecionadas e o secretário estadual de saúde assinaram termos, onde nele manifestaram o compromisso e a adesão ao projeto, estes termos foram posteriormente publicados em Diário Oficial.

- Contratação de Instituição Acreditadora Credenciada (IAC): Para proceder àas etapas de diagnóstico e certificação, era necessária a contratação de empresa certificadora utilizando os critérios: a capacidade técnica, disponibilidade de avaliadores, interesse em participar do projeto, presença de profissional odontólogo no staff e experiência comprovada na acreditação de serviços odontológicos, tendo em vista a dimensão e os riscos envolvidos no projeto. Feita esta avaliação, foi identificado que o Instituto Brasileiro para Excelência em Saúde (IBES), atendia as necessidades da SESA. 
- Diagnóstico Organizacional: Em agosto de 2015 iniciaram os diagnósticos das unidades pela IAC, ao qual avaliou as unidades conforme os requisitos dos manuais da ONA. Ao final, foi emitido um relatório, onde eram relacionados os pontos fortes da instituição, as não conformidades identificadas durante a visita e as observações como oportunidades de melhoria.

- Etapa de Preparação: Em posse deste relatório, as unidades iniciaram a etapa de preparação para a certificação, esta etapa, foi desenvolvida por meio de projetos específicos:

a) Plano de Ação: elaboração de um plano de ação, para tratamento das não conformidades e observações descritas no relatório de diagnóstico. Estas não conformidades foram divididas em projetos estratégicos pela unidade a fim de melhor organizar a execução e o monitoramento destes que aconteciam por meio das auditorias internas da qualidade.

b) Planejamento Estratégico: construção de identidade organizacional e análise de cenários que subsidiariam a elaboração do mapa estratégico, um painel de indicadores pelo método Balanced Scorecard (BSC), instrumentalização do planejamento estratégico da gestão, na qual se observa esse método como facilitador e orientador das atividades, do controle fiscal e do aprimoramento das atividades e plano de ação da unidade.

c) Mapeamento de Processos e Gestão de Riscos: neste projeto foram identificadas e priorizadas as variáveis mais significativas dos processos de trabalho. Para esta etapa, foi estabelecida a cadeia de valor das unidades e o mapeamento dos processos e riscos. Para tanto, utilizou-se as ferramentas: Suppliers (fornecedores), Inputs (entradas), Process (processo), Outputs (saídas) e Customers (clientes) (SIPOC), a matriz de tolerabilidade (ALARP) e a matriz (GUT), que considera os critérios de Gravidade, Urgência e Tendência, para a priorização e tratamento dos riscos dos processos. Após a realização do mapeamento dos processos e riscos, foi realizada a contratualização entre os processos críticos, com a pactuação de produtos e metas.

d) Políticas Institucionais e Protocolos de Segurança: a construção das políticas institucionais e de protocolos de segurança direcionaram os processos de trabalho para o alcance dos resultados esperados. Foram instituídas 11 (onze) políticas (Qualidade, Segurança do Paciente, Avaliação e Qualificação de Fornecedores, Registro Seguro, Gestão de Pessoas, Gestão Ambiental, Custos, Segurança da Informação, Suprimentos e Comunicação Institucional), bem como 06 protocolos de Segurança com suas ferramentas pertinentes (Identificação do Paciente, comunicação entre profissionais, segurança no uso de medicamentos, cirurgia segura, higienização das mãos, prevenção de quedas).

e) Notificação e tratativa de eventos: instituição do comitê de segurança do paciente, definição do plano de segurança do paciente, instituição de sistemática para notificação e tratativas de eventos adversos ocorridos na unidade.

f) Gestão da Qualidade: foi instituído o Escritório da Qualidade para controle e acompanhamento dessas notificações bem como controle de todos os documentos institucionais, desde sua elaboração e, aprovação, até codificação e distribuição para os setores pertinentes, realização das auditorias internas da qualidade, bem como o monitoramento do desempenho dos processos em relação ao plano estabelecido. 
g) Encerramento do projeto: realizada oficina de encerramento com as unidades participantes e equipe SESA, onde na oportunidade foram sistematizadas as lições aprendidas, definição de ações visando a sustentabilidade do processo e a divulgação dos resultados alcançados.

Concomitante a todo esse processo, houve adequação a toda legislação pertinente aos serviços de saúde e odontológico, bem como trabalhista, ambiental, entre outras.

- $\quad$ Etapa de manutenção: Ao fim do processo, as unidades entraram em processo de manutenção das certificações, com a realização de reuniões técnicas, destinada àa troca de melhores práticas e padronização de alguns processos.

Figura 01: Linha do tempo Execução do Projeto Piloto Acreditação.

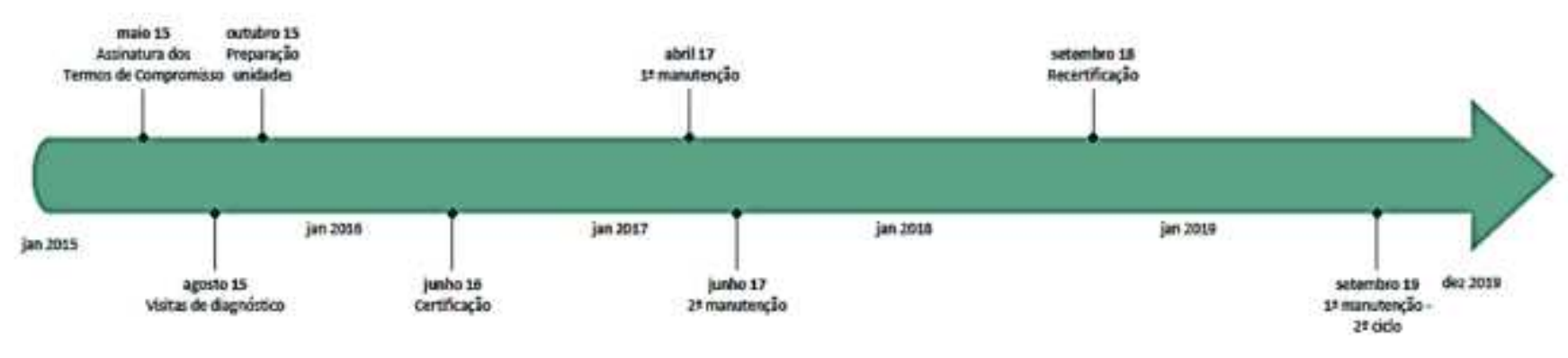

Fonte: Adaptado dos Autores

\section{RESULTADOS E DISCUSSÃO}

Das nove unidades que participaram do projeto piloto, oito concluíram o processo e foram acreditadas. Duas delas, um CEO e uma Policlínica, alcançaram o selo de acreditado pleno, o que significa que a instituição além de atender aos critérios de segurança, apresenta maturidade e integração entre os processos.

A Acreditação dos CEO consta como um produto inovador do PROEXMAESI, tendo em vista que até o ano de 2016 não havia serviços odontológicos certificados no país, sendo o estado do Ceará pioneiro e motivador de outros serviços nesta categoria.

A evolução percebida nessas unidades que representam um amadurecimento institucional foram: padronização e monitoramento de processos (unidades); identificação, mapeamento e estabelecimento de barreiras aos riscos dos processos; utilização de ferramenta de gestão para potencialização dos resultados da instituição; implantação e operacionalização dos Núcleos de Segurança do Paciente; melhoria no gerenciamento de resíduos dos serviços; adesão àas melhores práticas assistenciais; instituição de Políticas Institucionais; gestão das notificações e tratativa dos eventos adversos (melhoria dos processos); gerenciamento de protocolos clínicos. 
Para Rede de Atenção à Saúde estadual pode-se perceber: o desenvolvimento e padronização da política de segurança do paciente no nível ambulatorial; melhoria da eficiência das unidades; medição de desempenho e detecção inconformidades dos processos; identificação e sistematização das conformidades e oportunidades de melhoria para melhoria das práticas; promoção a cooperação interna entre processos e pessoas das equipes; apoio (suporte) aos demais níveis de atenção na região; instituição de um padrão de qualidade para a rede.

Entretanto, dentre os principais ganhos desse processo podemos destacar a disseminação da cultura da qualidade entre as unidades, o estabelecimento de uma rede de cooperação entre diretores e funcionários dos serviços e a promoção da cultura do autodiagnóostico que identifique oportunidades de melhoria.

\section{CONCLUSÃOE CONSIDERAÇÕES}

A acreditação das unidades ambulatoriais durante o PROEXMAES I representou um avanço no padrão de qualidade e o fortalecimento das boas práticas de gestão para as unidades na Rede SESA. Essa experiência colocou a saúde do Estado do Ceará em destaque no cenário nacional, tanto pelo resultado quanto pelo pioneirismo, tendo em vista a acreditação dos primeiros serviços de odontologia.

O processo de aprendizagem e os resultados oportunizados no PROEXMAES I, subsidiou a expansão de qualificação dos serviços em uma segunda etapa do programa a ser implementada na Rede SESA PROEXMAESII. 


\section{REFERÊNCIAS}

BRASIL. Agência Nacional de Vigilância Sanitária. Resolução RDC №36. 2013.

CAVALCANTE, P. (Org.). Inovação e Políticas Públicas: superando o mito da ideia. 1. ed. Brasília: Ipea, 2019.

MAINARDES,W.E; LOURENÇO,L; TONTINI,G. Percepções dos conceitos de qualidade e gestão pela qualidade total: estudo de caso na universidade. Revista eletrônica de gestão organizacional, Lisboa, v.8,f.2, p.279-297, mai-ago, 2010. Disponível em: http://www.revista.ufpe.br/gestaoorg/index.php/gestao/article/view/2014 Acesso em: 03 fev. 2020.

Organização Nacional de Acreditação - ONA. Manual Brasileiro de Acreditação: Organizações Prestadoras de Serviços de Saúde - Versão 2018.

ORGANIZAÇÃO NACIONAL DE ACREDITAÇÃO, 2020. Disponível em:<https://www.ona.org.br/Pagina/ 23/Historico>. Acesso em: 14 fev. 2020.

SILVA, K; MOREIRA, J.A.A; VASCONCELOS, L.T et al. Gestão da qualidade total nos serviços de saúde: modelo gerencial em desenvolvimento. Revista Eletrônica Gestão \& Saúde. V.06. №01. 2015. 


\section{SISTEMAS INTELIGENTES DE TRANSPORTES E SUAS APLICAÇÕES PARA O AUMENTO DA EFICIÊNCIA NO TRANSPORTE DE CARGAS: UMA REVISÃO DA LITERATURA.}

Isabela Kopperschmidt de Oliveira

Universidade Federal de Minas Gerais - UFMG

\begin{abstract}
RESUMO
O aumento populacional traz consigo um aumento de demanda por mercadorias, enquanto o desenvolvimento tecnológico aumenta a complexidade da cadeia de suprimentos. Com isso as externalidades oriundas da atividade de transporte necessitam ser reduzidas ao se esperar um desenvolvimento sustentável das cidades. O conceito de Sistemas Inteligentes de Transportes se encaixa no conceito da logística urbana, pois é uma ferramenta para se alcançar os objetivos da ciência, permitindo alcançar o desenvolvimento sustentável das cidades na
\end{abstract}

medida que também aumenta sua competitividade no cenário internacional. Técnicas de CVO e AFSM podem ser usadas para aumentar a eficiência do transporte de cargas tanto a nível institucional quanto empresarial.

\section{Palavras-chave:}

Logística Urbana; Sistemas Inteligentes de Transportes; Transporte de Cargas; Externalidades; Sustentabilidade.

\footnotetext{
ABSTRACT

Population growth brings with it an increase in demand for goods, while technological development increases the complexity of the supply chain. Thus, the externalities arising from the transport activity need to be reduced when waiting for the sustainable development of cities. The concept of Intelligent Transport Systems fits the concept of city logistics, as it is a tool to achieve the objectives of its science, as it allows to achieve the sustainable development of cities, as it also increases their competitiveness in the
}

international scenario. CVO and AFSM techniques can be used to increase the efficiency of cargo transportation at both institutional and corporate levels.

\section{Keywords:}

City Logistics; Intelligent Transportation System;

Urban Freight; Extemalities; Sustainability. 


\section{INTRODUÇÃO}

O avanço rápido das tecnologias e o consequente aumento de produtos tornou a cadeia produtiva mais complexa. Essa complexidade não é encontrada apenas no processo de produção, mas também no sistema de entrega dos produtos a serem comercializados pelas empresas. Novos conceitos do sistema de produção moderno trouxeram consigo ideais de estoque mínimo, desperdício mínimo e compras virtuais, o que torna mais complexa ainda a atividade de entregar e receber mercadorias (ANAND et al., 2015).

O movimento de mercadorias passou a ocupar um papel de destaque no mercado atual, pois consome parte significante dos custos operacionais de uma empresa (SHEN et al., 2015). Algumas estatísticas foram levantadas por diversas entidades no mundo, o CSCMP (Council of Suply Chain Management Professionals) estima que nos EUA os custos logísticos, de 2012, atingiram o patamar de US\$1,33 trilhões, que representa 8,5\% dos produtos domésticos desse país. Na China, essa fração foi de $13 \%$ (SHEN et al., 2015).

Em geral, uma cidade gera 0,1 entregas por pessoa por dia, 1 entrega por trabalho por semana, entre 300 e 400 viagens de caminhão a cada 1000 pessoas por dia e entre 30 e 50 toneladas de mercadorias por pessoa por dia (DABLANC, 2009). A carga urbana representa entre 10 e $15 \%$ das viagens realizadas em áreas urbanas e essa atividade emprega até $5 \%$ da força de trabalho (DABLANC, 2009). Além disso, as instalações logísticas ocupam entre 3 e $5 \%$ do espaço urbano (DABLANC, 2009).

Em face das crescentes externalidades negativas do transporte urbano de cargas, alguns municípios têm se preocupado em regulamentar o trânsito de veículos pesados, assim como também têm regulamentado a atividade de carga/descarga. Em sua maioria, a postura do poder público é restringir o acesso dos veículos de carga, pois em geral eles são vistos como indesejados no meio urbano (TADIC et al., 2015). A intervenção dos gestores públicos e da polícia local com medidas restritivas de circulação de caminhões dificulta as entregas pelas empresas (VISSER et al., 1999). Nesse sentido, a utilização de tecnologia é uma solução para otimizar o sistema logístico de maneira sustentável e agregarvalor à atividade.

$\mathrm{O}$ alto custo que o transporte agrega na atividade logística demonstra a necessidade de se pensar em novas alternativas que reduzam os custos dessa atividade e aumentem a competitividade das empresas brasileiras em contexto nacional e internacional. A nível internacional, o sistema de transporte tem sido otimizado a partir da utilização de tecnologia da informação e da comunicação. Assim é necessário tomar ciência dessas tecnologias e das possibilidades de otimização que o sistema logístico pode ter, pois para que haja um aumento de eficiência na logística brasileira é necessário o conhecimento e engajamento de todos os stakeholders envolvidos na atividade logística, não sendo só função do governo fornecer a infraestrutura necessária. Assim, esse trabalho busca compilar algumas alternativas para despertar o interesse da comunidade brasileira sobre o transporte de carga e o uso de tecnologia na rotina das cidades.

O objetivo geral desse trabalho é demonstrar a relevância da ciência da utilização de tecnologia - na forma de Sistemas Inteligentes de Transportes. Para isso, o trabalho tem como objetivos específicos 
demonstrar, a partir de uma revisão da literatura, a relevância da ciência da logística urbana, identificar as externalidades do transporte urbano de carga e citar as principais soluções de sistemas inteligentes de transportes, propostas pela academia para otimizar o transporte de cargas.

Este trabalho ainda se torna mais relevante no contexto de 2020 e 2021, que com o cenário brasileiro e internacional desencadeado pela COVID-19. Apenas na transição do ano de 2019 para 2020 o número de pedidos realizados pelo e-commerce aumentou em 39\%, e o número de consumidores aumentou em 40\% (WEBSHOPPERS, 2020). Esse cenário revela um aumento da pulverização das entregas e o aumento dos desafios para a redução dos custos operacionais do transporte para as empresas

\section{METODOLOGIA}

O seguinte artigo conta com uma revisão sistemática da bibliografia a cerca das principais tecnologias utilizadas no mundo para otimizar o sistema de entrega no meio urbano, as externalidades do transporte de cargas e a logística urbana.

\section{RESULTADOS}

Essa seção apresenta as principais observações retiradas da literatura para construir a importância da aplicação dos sistemas inteligentes de transportes no transporte de cargas.

\subsection{Externalidades do Transporte de Cargas}

Desde os anos 70, o mundo tem experimentado altas taxas de urbanização, e atualmente $54 \%$ das pessoas vivem em áreas urbanas, e a projeção é que em 2050 esse número atinja 66\% (ONU, 2018). Um estudo realizado pelo grupo CIVITAS estima que em 2030 o consumo energético relacionado aos fretes urbanos será $45 \%$ do consumo relacionado à atividade de transporte (ANAND et al., 2015). Esse aumento populacional em áreas urbanas faz com que a demanda de produtos e serviços cresçam nesse espaço (ANAND et al., 2012). Essa demanda crescente aumenta o número de viagens para realizar entregas, aumentam os congestionamentos, reduzem a segurança nas vias e aumentam os níveis de poluição (ANAND et al., 2012). Estudos realizados pela Uniontrasporti em 2009 (RUSSO e COMI, 2012) apontam em números os custos associados às externalidades do transporte, disponíveis na Tabela 01. Nela é possível perceber o quão impactante o transporte de mercadorias é nos quesitos poluição atmosférica e congestionamento, sendo que a atividade também se mostra muito mais impactante, quanto ao custo de suas externalidades, que o transporte de passageiros.

Tabela 01 - Custos das Externalidades do Transporte (RUSSO E COMI, 2009 - Adaptado)

\begin{tabular}{|l|c|c|l|c|c|c|}
\hline & $\begin{array}{l}\text { Efeito } \\
\text { Estufa }\end{array}$ & $\begin{array}{l}\text { Poluição } \\
\text { Atmosférica }\end{array}$ & $\begin{array}{l}\text { Poluição } \\
\text { Sonora }\end{array}$ & Segurança & Congestionamento & Total \\
\hline $\begin{array}{l}\text { Passageiros } \\
\text { (centenas } \\
€ / \text { passageiro.km) }\end{array}$ & 1,17 & 4,84 & 2,62 & 5,44 & 4,38 & 18,17 \\
\hline $\begin{array}{l}\text { Carga (centenas } \\
\text { €/toneladas.km) }\end{array}$ & 1,73 & 24,81 & 5,31 & 0,3 & 10,79 & 44,94 \\
\hline
\end{tabular}

Fonte: Da autora 


\subsection{Logística Urbana}

A logística urbana é uma nova área de estudo originada do aumento dos fretes realizados dentro das áreas urbanas, diariamente (CAVAR et al., 2011). São do escopo desse campo de estudo a atividade de entrega e coleta de mercadorias (transporte, carregamento, estoque, gestão de estoque, desperdícios, retorno e entregas domiciliares) ao mesmo tempo que se preocupa com o congestionamento, a segurança viária, os impactos ambientais e o consumo de energia (CAVAR et al., 2011). Assim os gestores urbanos tem interferido cada vez mais na cidade para melhorar a circulação de carga no meio urbano e para aumentar a competitividade da empresa (ANAND et al., 2015).

A logística urbana trabalha o conceito de otimização total ao invés de otimização parcial do transporte e da logística (TANIGUCHI, 2015). A diferença da logística urbana para a logística comercial é q u e n a segunda, apenas as empresas participam do processo de decisão enquanto na primeira o setor público e a população têm voz no processo (TANIGUCHI, 2015). Tratar da logística urbana significa conciliar os desejos de quatro grupos de stakeholders, conforme Figura 01. Os administradores das empresas desejam enviar os produtos com maior nível de confiança e menor custo (TANIGUCHI, 2015). Os transportadores desejam maximizar seus lucros reduzindo os custos (TANIGUCHI, 2015). Os administradores públicos desejam integração regional, nacional e municipal, além de melhoria no meio ambiente e desenvolvimento econômico (TANIGUCHI, 2015). Os residentes desejam ruas mais silenciosas, seguras e com meio ambiente preservado e puro (TANIGUCHI, 2015).

FIGURA 01 - Stakeholders da Logística Urbana (TANIGUCHI, 2015 - Adaptado)

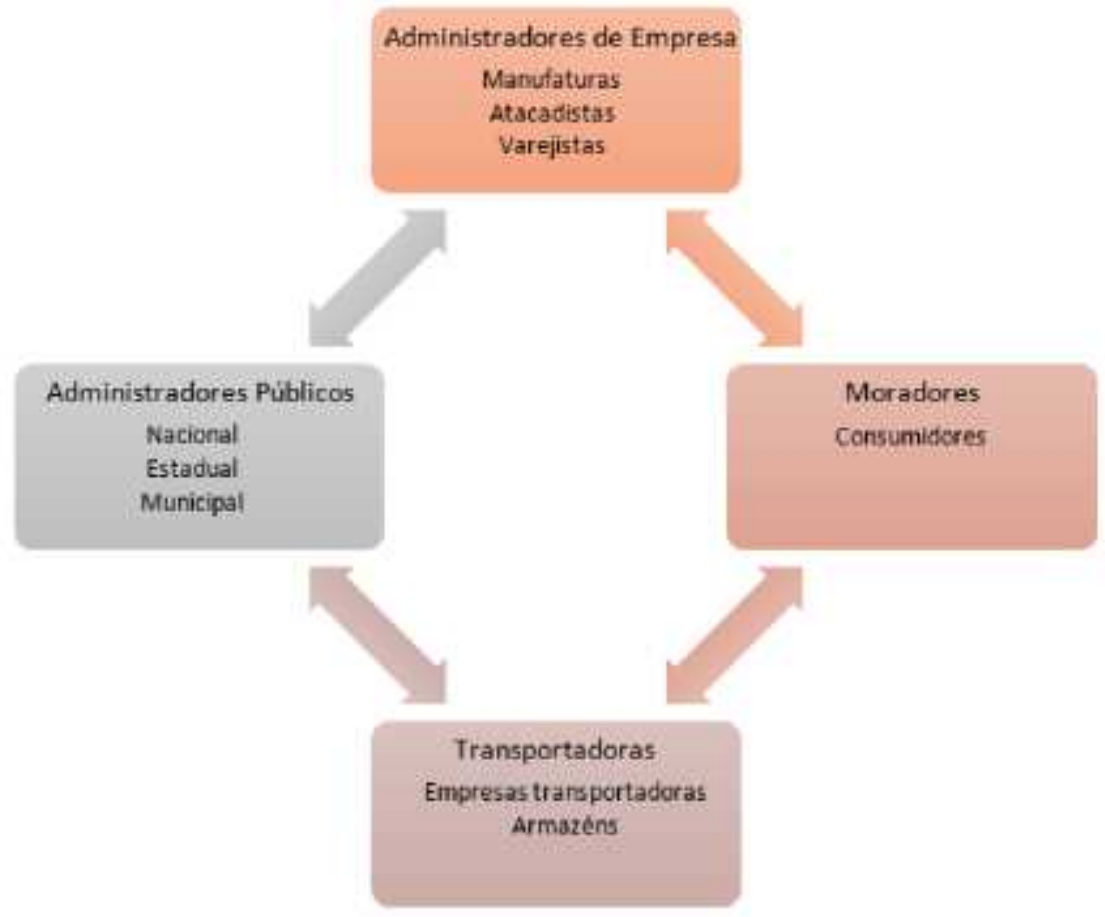

Fonte: Da autora

A logística urbana possui três pilares (Figura 02): mobilidade, sustentabilidade e habitabilidade. Para cada um desses pilares, são avaliados oito critérios, sendo eles: competitividade, eficiência, amigável ao meio ambiente, redução de congestionamento, segurança viária, segurança pública, conservação de energia e força de trabalho. Integrando esses oito objetivos com os três pilares da logística urbana é 
esperado que se obtenha um ambiente urbano amigável ao transporte urbano de carga (TANIGUCHI, 2015), não hostil que apenas impõe limitações e restrições ao transporte urbano de cargas, o tornando não sustentável e reduzindo a competitividade das empresas inseridas nesse contexto (ALLEN et al., 2000; BALLANTYNE et al., 2013; DABLANC, 2007; HOLGUÍN-VERAS et al., 2013; QUAK, 2008; QUAK; DE KOSTER, 2009). Outro fator que tem sido considerado na logística urbana é a resiliência do meio urbano, sendo esse fator muito importante em locais cuja susceptibilidade a desastres naturais como furacões e terremotos são uma constante na vida da população (TANIGUCHI, 2015). Nesses locais a logística humanitária, que garante o abastecimento de água e alimentos, se torna um componente de planejamento importante (ZEIMPEKIS et al., 2013; TANIGUCHI et al., 2014).

FIGURA 02 - Pilares e Critérios da Logística Urbana (TANIGUCHI, 2015 - Adaptado)
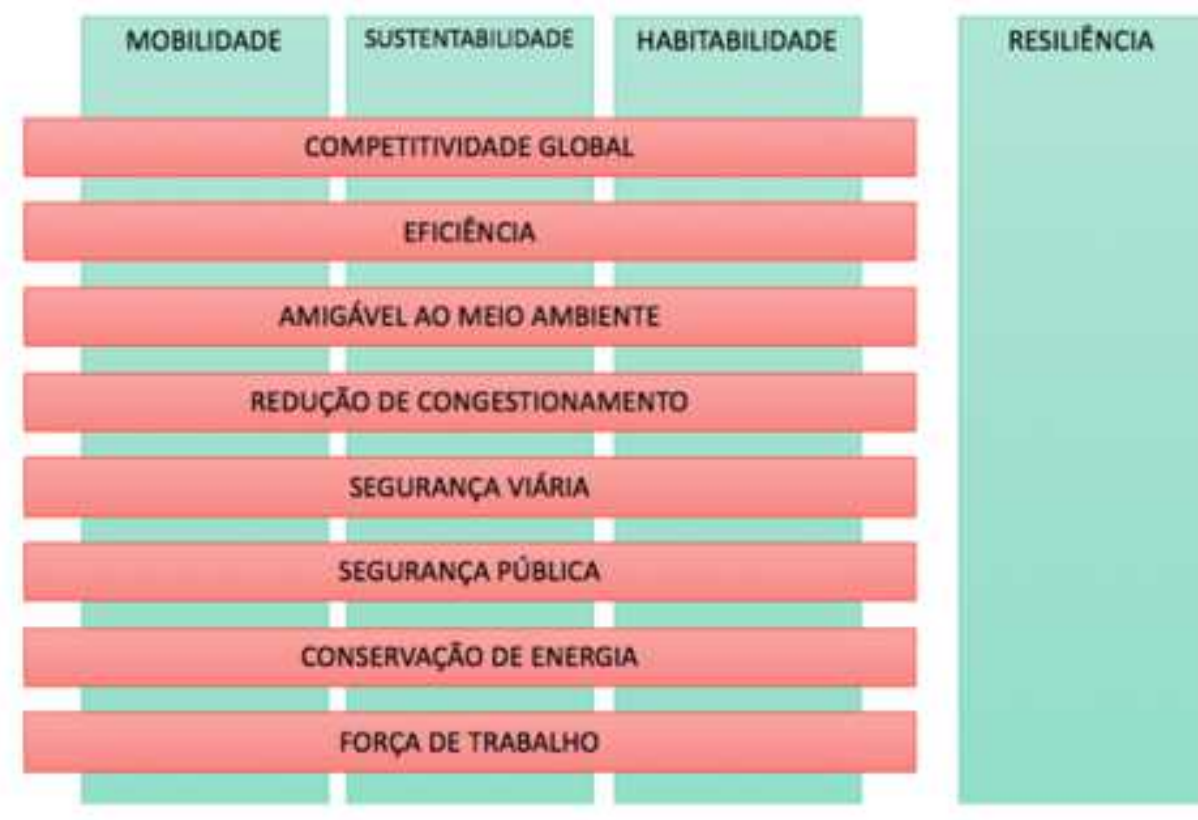

Fonte: Da autora

\subsection{Sistemas Inteligentes de Transportes (ITS)}

O termo Sistemas Inteligentes de Transportes ou Intelligent Transportation System (ITS) é utilizado quando se deseja definir uma gama de tecnologias, infraestruturas e serviços utilizados para o transporte de pessoas e cargas, sendo que os ITS estão presentes nas etapas de planejamento, operação e controle do sistema que compõe o transporte (CRAINIC et al., 2009). A necessidade de se incorporar tecnologia no transporte surge da ineficácia observada com o aumento de infraestrutura para comportar o aumento de veículos, sendo observada a necessidade de se otimizar o sistema já existente em razão de apenas aumentá-la (CRAINIC et al., 2009).

O conceito de aplicação de tecnologia no transporte não é novo, ou surgiu recentemente, ele é apenas a consolidação da evolução natural que o sistema de transporte sofre com o desenvolvimento tecnológico da gestão do transporte, seja a nível governamental ou a nível empresarial (CRAINIC et al., 2009). O que é novo no ITS é o conceito de sinergia entre os componentes tecnológicos (CRAINIC et al., 2009). 


\subsubsection{ITS e a Logística}

As Tecnologias da Informação e Comunicação (ICT - Information and Communication Technology) e os Sistemas Inteligentes de Transportes (ITS - Intelligent Transportation Systems) desempenham papel importante para a logística urbana atingir seus objetivos (TANIGUCHI, 2015). Por a logística urbana tratar da otimização de objetivos múltiplos, a capacidade de tratar informações de maneira dinâmica - proporcionado pelo ICT e ITS - permite a redução dos custos de distribuição urbana e das emissões de poluentes (TANIGUCHI, 2015).

Os ITS de carga podem ser divididos em duas classes: Commercial Vehicle Operations (CVO) e Advanced Fleet Management Systems (AFMS) (CRAINIC et al., 2009). A primeira diz respeito a sistemas de grande alcance territorial, abarcando as áreas de um município até um continente. Já a segunda são os sistemas voltados para operações particulares, dentro de uma empresa (CRAINIC et al., 2009).

Para o transporte de carga, o ITS se manifesta na consolidação da relação entre a troca de dados eletrônicos (Eletronic Data Interchange - EDI) e o transporte de mercadorias, sendo que o antecessor dos sistemas CVO e AFMS são a aplicação das tecnologias de EDI no compartilhamento de informaçõess obre a posição de veículos e mercadorias, a partir de um canal de comunicação de via dupla (ALLEN et al., 1992; JOHNSON et al., 1992; CRUM et al., 1998; ROY et al., 1997; WALTON., 1994). Assim, o EDI pode ser definido como a troca de informações, interorganizacional, entre computadores, em um formato que os dados possam ser processados (EMMELHAINZ, 1990).

Sistemas como GPS (Global Position System), Sistemas Automáticos de Identificação, EDI e sistemas similares ainda têm relevante impacto nas operações de frete e na performance do sistema de transporte, especialmente em operações multimodais (CRAINIC et al., 2009). Entretanto, novos sistemas têm sido propostos, principalmente pela academia, como uma maneira de melhorar os sistemas de EDI e otimizar toda a cadeia logística e agregar valor às atividades de supply chain (CRAINIC et al., 2009).

A nível de otimização, os ITS possuem três áreas de atuação. A primeira é a de roteirização e agenda (routinf and scheduling problems - VRP, ou routing and scheduling problems with time windows VRPTW) (TANIGUCHI et al., 2012). De natureza dinâmica ou estocástica, estudar a demanda e compreender seu comportamento é um ponto de estudo a anos, com autores como Powell, Jaillet e Odoni, Bertsimas et al., Gendreu et al., Ficliozzi et al., Woensel et al. e Wen et al., sendo nomes de referência no que concerne a modelagem da demanda sob o ponto de vista do VPR (TANIGUCHI et al., 2012). Os problemas de VRPTW são mais complexos, principalmente de um sistema urbano, sendo os principais estudiosos desse tema Soler et al., Fligliozzi, Maden et al. e Thompson et al. (TANIGUCHI et al., 2012).

A segunda área de atuação para a otimização é a relacionada com os multiobjetivos dos agentes da cadeia logística. O processo de avaliação multicriterial tem sido utilizado como ferramenta de suporte à decisão que atenda, da melhor maneira possível, os diferentes objetivos da cadeia (TANIGUCHI et al., 2012). A ideia é identificar o Pareto ótimo e avaliar as diversas funções de maneira isolada, uma vez que elas não podem ser analisadas simultaneamente com o mesmo objetivo (TANIGUCHI et al., 2012). As soluções muitas vezes são obtidas por algoritmos heurísticos para obter soluções aproximadas a algoritmos genéticos (DEB et al., 2002; VIEIRA et al., 2004; ÁVILA et al., 2006), otimização por enxame de partículas (BAUMGARTNER et al., 2004), otimização por colmeia de formigas (ALAYA et al.; JAQUELINE; BARBOSA, 2011) ou algoritmo pesquisa Tabu (BAYKASOGLUAB et al., 1999; HO et al., 2002; JAEGGI et al., 2008). Diversos pesquisadores, como elenca Taniguchi et al. (2012), utilizaram dessas técnicas para otimizar as conflitantes curvas de custos e riscos (TANIGUCHI et al., 2012). 
Por fim, a última área envolve a inteligência dos softwares. Denominados inteligente agentes por Taniguchi et al. (2012), são sistemas computacionais capazes de alcançar seus objetivos de maneira capaz e flexível. Esses sistemas devem ser capazes de ganhar experiência e identificar padrões de ações para reagirem às "perturbações" do ambiente, podendo ou não agir de maneira proativa (TANIGICHI et al., 2010). São sistemas capazes de solucionar problemas de otimização complexos em ambientes dinâmicos, como aeroportos (LAM et al., 2002).

\subsubsection{Commercial Vehicle Operations (CVO)}

CVO é a denominação dada ao sistema que busca simplificar e automatizar o sistema de fretes e gestão operacional a nível institucional. Nele estão contidas as informações sobre os veículos e a rede, focando na segurança na troca de informação acerca de credenciais administrativas eletrônicas e monitoramento eletrônico das rodovias (CRAINIC et al., 2009). A infraestrutura necessária é instalada a partir de parcerias de autoridades públicas e empresas, com o objetivo de melhorar a performance da infraestrutura e do sistema de consumo ao simplificar e automatizar o controle do transporte tanto a nível governamental quanto operacional-empresarial (CRAINIC et al., 2009). Esses sistemas se apoiam em tecnologias já conhecidas e desenvolvidas como: sistemas de monitoramento da posição dos veículos - GPS e frequência de rádio -, comunicação bidirecional-rádio, satélite, celulares -, e EDI (CRAINIC et al., 2009).

Os primeiros sistemas CVO foram instalados nos "corredores" viários de relevância, principalmente em vias expressas, nos EUA na segunda década de 90, sendo esse sistema baseado na tecnologia de EDI (CRAINIC et al. 2000; CRAINIC et al. 2001; CRAINIC et al., 2009). Na Austrália existe um sistema de monitoramento de caminhões, chamado TruckScan system, que usa recursos visual de identificação dos veículos, e reconhecem atributos como peso, comprimento, altura e trajetória (REID; MYERS, 1996; CRAINIC et al. 2009). No Japão o foco do sistema é obter informação em tempo real e processála em tempo real também, e não só a infraestrutura de transporte é monitorada mas também os centros logísticos, e toda essa informação é integrada (MLITT, 2007; MLITT, 2008). A Comunidade Europeia tem um amplo programa de desenvolvimento de ITS que é marcado pela sinergia entre stakeholders, pela cooperação entre os países que compõem a comunidade e é baseado na multimodalidade (CRAINIC et al., 2009).

\subsubsection{Advanced Fleet Management Systems (AFMS)}

O AFMS é um Sistema que busca simplificar e automatizar a atividade do transporte e a gestão operacional a nível business-to-business (CRAINIC et al., 2009). Sendo que uma vez instalados os equipamentos na frota e nos computadores da empresa, todas as informações a cerca do frete e do veículo são captadas e armazenadas, sendo que os dados são analisados e se tornam subsídio para tomada de decisão nas empresas (CRAINIC et al., 2009).

Esses sistemas ajudam a atividade de transporte na hora de planejar e cumprir os prazos, calcula de maneira eficiente o ponto de alocação de instalações logísticas e com isso, aumenta o nível de satisfação do cliente (CRAINIC et al., 2009). Diferentemente dos sistemas de ITS que estão sendo construídos, ainda há pouca utilização de inteligência artificial nesse sistema, sendo uma área para evolução das tecnologias (CRAINIC et al., 2009). 
O grande ganho de utilizar os sistemas AFSM é a possibilidade de controlar e coordenar as operações em tempo real (CRAINIC et al., 2009). Assim a tecnologia se mostra bastante eficiente em se tratando de transporte que a demanda não é previsível e para operações multimodais (BEKTAS; CARINIC, 2008; CRAINIC et al., 2006, CRAINIC et al., 2009).

\section{CONCLUSÃO}

Em face do aumento populacional e do desenvolvimento tecnológico, o consumo aumentou, e com isso aumentou a atividade de transporte de carga, no mundo inteiro. Assim, incluir o transporte de mercadorias no planejamento urbano, não só traz benefícios ao meio ambiente, mas também aumenta a competitividade econômica da região. Com isso surge a ciência da logística urbana, para pensar soluções que tornem o transporte urbano de cargas mais sustentável e mais competitivo.

A tecnologia avança não só para a indústria, mas para a gestão de operações também, assim como para o sistema logístico. Desse avanço surge o conceito de ITS, que utiliza da tecnologia para otimizar a rede disponível e agregar valor a uma atividade que representa custos para as empresas.

Entre ferramentas de gestão a nível institucional e a nível empresarial, a revisão da literatura trouxe exemplos de ferramentas que auxiliam tanto gestores públicos quanto empresas a aumentarem a eficiência de suas redes e com isso reduzir as externalidades negativas do transporte de cargas. Assim, esse trabalho cumpre seu objetivo de mostrar algumas tecnologias que podem ser empregadas no transporte de carga para otimizar a atividade logística. 


\section{REFERÊNCIAS}

ALAYA, I.; SOLNON, C.; GHEDIRA, K. Ant colony optimization for multi-objective optimization problems. Proceedings of the 19th IEEE International Conference on Tools with Artificial Intelligence. 2007. v. 1 p. 450-457.

ALLEN, J.; ANDERSON, S.; BROWNE, M.; JONES, P. A framework for considering policies to encourage sustainable urban freight traffic and goods/service flows. Transport Studies Group, University of Westminster, London. 2000.

ALLEN, J.B.; CRUM, R.M.; BRAUSCHWEIG, D.C. The US motor carrier industry: the extent and nature of EDI use. International Journal of Physical Distribution and Logistics Management. 1992 n. 8 v.22 p. 27-34.

ANAND, N.; QUAK, H.; VAN DUIN, R.; TAVASSZY, L. City Logistics Modelling Efforts: Trends and Gaps- A Review. Procedia-Social and Behavioral Sciences. 2012, p. 101-115. DOI: ISSN 1877-0428.

ANAND, N.; VAN DUIN, R.; QUAK, H.; TAVASSZY, L. Relevance of City Logistica Modelling Efforts: A Review. Transport Review. 2015. DOI: 10.1080/01441647.2015.1052112.

AVILA, S. L.; LISBOA, A. C.; KRAHENBUHL, L.; CARPES, W. P.; VASCONCELOS, J. A.; SALDANHA, R. R.; TAKAHASHI, R. H. C. Sensitivity analysis applied to decision making in multiobjective evolutionary optimization. IEEE Transactions on Magnetics. 2006. v. 42 p. 1103-1106.

BALLANTYNE, E.; LINDHOLM, M.; WHITEING, A. 2013. A comparative study of urban freight transport planning: addressing stakeholder needs. Journal of Transport Geography. DOI: http://dx.doi.org/10.1016/j. jtrangeo.2013.08.013, 32: 93-101.

BAUMgartneR, U.; MAgele, C.; RENHAR, T. Pareto optimality and particle swarm optimization. IEEE Transactions on Magnetics. 2004. v. 40 p. 1172-1175.

BAYKASOGLUAB, A.; OWENA, S.; GINDYA, N. A. taboo search based approach to find the Pareto optimal set in multiple objective optimization. Engineering Optimization. 1999. n. 6 v. 31 p. 731-748.

BEKTAS, T.; CRAINIC, T. C. A brief overview of intermodal transportation. In: Taylor, G.D. (Ed.). Logistics Engineering Handbook. 2008. Taylor and Francis Group, Boca Raton. p. 1-16 (Chapter 28).

CAVAR, I.; KAVRAN, Z.; JOLIC, N. Intelligent Transportation System and Night Delivery Schemes for City Logistics. Computer Technology and Application 2. 2011, p. 782-787. DOI: ISSN 1934-7340.

CRAINIC, T. G.; BILEGAN, I. C.; GENDREAU, M. Fleet management for advanced intermodal services. Transport Canada. 2006.

CRAINIC, T. G.; GENDREAU, M.; LEBEUF, D. Making intelligent transportation systems more intelligent: the contribution of operations research. 7th World Congress on Intelligent Transport Systems. 2000. Torino, Italia.

CRAINIC, T. G.; GENDREAU, M.; LEBEUF, D. Intelligent transportation systems: an historic assessment and the role of operations research. CRT- 2001-26. 2001.

CRAINIC, T.; RICCIARDI, N.; STORCHI, G. Models for evaluating and planning city logistics systems. Transportation Science. 2009. v. 43 p. 432-454.

CRUM, M. R.; JOHNSON, A. D.; ALLEN, J. B. A longitudinal assessment of EDI use in the US motor carrier industry. 1998. Transportation Journal. v. 38 p. 15-28. 
DABLANC, L. Goods transport in large European cities: Difficult to organize, difficult to modernize. Transportation Research Part A: Policy and Practice. 2007. n. 3 v.41 p. 280-285.

DABLANC, L. Freight Transport for Development Toolkit: Urban Freight. 2009 Disponível em: <http://siteresources.worldbank.org/INTTRANSPORT/Resources/336291-1239112757744/59976931266940498535/urban.pdf>/ Acesso em agosto de 2019.

DEB, K.; PRATAP, A.; AGARWAL, S.; MEYARIVAN, T. A fast and elitist multiobjective genetic algorithm: NSGA-II. IEEE Transactions on Evolutionary Computation 2002. v. 6 p. 182-197.

EMMELHAINZ, M. A. Electronic Data Interchange: A Total management Guide. 1990. Van Nostrand Reinhold, New York.

HOLGUÍN-VERAS, J.; CRUZ, C. A. T.; BAN, J. X. On the comparative performance of urban delivery vehicle classes. Transportmetrica A: Transport Science. 2011. n.1 v. 9 p. 50-73. DOI:10.1080/18128602.2010.523029.

HO, S. L.; YANG, S.; NI, G.; WONG, H. C. A tabu method to find the Pareto solutions for multiobjective optimal problems in electromagnetic. IEEE Transactions on Magnetics. 2002. v. 38 p. 1013-1016.

JAEGGI, D. M.; PARKS, G. T.; KIPOUROS, T.; CLARKSON, P. J. The development of a multi-objective Tabu Search algorithm for continuous optimisation problems. European Journal of Operational Research. 2008. n. 3 v. 185 p. 1192-1212.

JAQUELINE, S. A.; BARBOSA, H. J. C. On ant colony optimization algorithms for multiobjective problems. Ostfeld A. 2011. p.139-153.

JOHNSON, A.D., ALLEN, J.B., CRUM, M.R. The state of EDI usage in the motor carrier industry. Journal of Business Logistics. 1992 n. 2 v.13 p. 43-68.

LAM, S. H.; CAO, J. M. C.; FAN, H. Development of an intelligent agent for airport gate assignment. Journal of Air Transportation. 2002. v. 7 p. 103-114.

MLITT. ITS handbook Japan 2006-2007, Highway Industry Development Organization. 2007. Road Bureau, Ministry of Land, Infrastructure, Transport and Tourism, Japão. Disponível em: <http://www.its.go.jp/ITS/topindex/topindex_g02_handbook.html> / Acesso em julho de 2019.

MLITT. Comprehensive plan for ITS in Japan. Highway Industry Development Organization. 2008. Road Bureau, Ministry of Land, Infrastructure, Transport and Tourism, Japão. Disponível em: http://www.its.go.jp/ITS/ topindex/topindex_g06_2.html>/ Acesso em julho de 2019.

ONU. Population Division - World Urbanization Prospects 2018. Disponível em $<$ https://population.un.org/wup/>/ Acesso em 28 de agosto de 2019.

QUAK, H. 2008. Sustainability of urban freight transport - Retail Distribution and Local Regulations in Cities. Erasmus Research Institute of Management (ERIM), Erasmus University, Roterdam, PhD.

QUAK, H. J.; DE KOSTER, M. B. M. Delivering Goods in Urban Areas: How to Deal with Urban Policy Restrictions and the Environment. Transportation Science. 2009. n. 2 v. 43 p. 211-227. DOI: 10.1287/trsc.1080.0235.

REID, P., MYERS, R. TruckScan - automating and improving roadside checking. Traffic Technology International. 1996.

ROY, J.; BIGRAS, Y.; CRAINIC, T. G. New information technologies and freight transportation. In: Roller, D. (Ed.). Proceedings of the 30th International Symposium on Automotive Technology and Automation, ATT/ITS Conference. 1997. ISATA, Florence, p. 291-298. 
RUSSO, F.; COMI, A. City Characteristic and Urban Goods Movements: A Way to Environmental Transportation System in a Sustainable System. The Seventh International Conference on City Logistics. 2012. p. 61-73. DOI: 10.1016/j.sbspro.2012.03.091.

SHEN, J.; QIU, F.; LI, W.; FENG, P. A New Urban Logistics Transport System Based on a Public Transit Service. CICPT 2015. 2015 p. 650-661. Disponível em: <https://ascelibrary.org/doi/10.1061/9780784479292.060>/ Acesso em: 20 de julho de 2019.

TADIC, S.; ZECEVIC, S.; KRSTIC, M. City Logistics - Status and Trends. International Journal for Traffic and Transport Engeneering. 2015. n. 3 v. 5 p. 319-343 DOI: http://dx.doi.org/10.7708/ijtte.2015.5(3).09.

TANIGUCHI, E. City Logistics for Sustainable and Liveable Cities. Green Logistics and Transportation. 2015. v. 4. DOI: 10.1007/978-3-319-17181-4.

TANIGUCHI, E.; FWA, T. F.; THOMPSON, R. G. Urban transportation and logistics: Health, safety, and security concerns. 2014.

TANIGUCHI, E.; THOMPSON, R. G.; YAMADA, T. Emerging Techniques for Enhancing the Pratical Apllication of City Logistics Models. Procedia - Social and Behavioral Sciences. 2012. v. 39 p. 3-18. DOI: 10.106/j.sbspro.2012.03.087.

VIEIRA, D. A. G.; ADRIANO, R. L. S.; VASCONCELOS, J. A.; KRAHENBUHL, L. Treating constraints as objectives in multiobjective optimization problems using niched Pareto genetic algorithm. IEEE Transactions on Magnetics. 2004. v. 40 p. 1188-1191.

VISSER, J.; VAN BINSBERGEN, A.; NEMOTO, T. (1999). Urban freight transport policy and planning. InFirst International Symposium on City logistics, July.

WALTON, L. W. Electronic data interchange (EDI): a study of its usage and adoption within marketing and logistics channels. Transportation Journal. 1994. n.2 v. 34 p. 37-45.

WEBSHOPPERS. (2020). Webshoppers 42a Edição. Disponível em: <https://myagmexpress.com/ downloads/Webshoppers_42.pdf>/ Acesso em: 06 de abril de 2021.

ZEIMPEKIS, V.; ICHOUA, S.; INIS, I. Humanitarian and relief logistics. 2013. Berlin: Springer. 


\title{
AS BASES TEÓRICOS-CONCEITUAIS (FRAMEWORK) DE AVALIAÇÃO DE DESEMPENHO E RESULTADOS APLICADOS NAS INSTITUIÇÕES DE SAÚDE NO BRASIL
}

\author{
Galba Freire Moita \\ Univ. Coimbra, CeBER - Centre for Business and Economics \\ Research, Faculty of Economics
}

\author{
Allan Claudius Queiroz Barbosa \\ Univ. Federal de Minas Gerais - UFMG / CEPEAD
}

\begin{abstract}
RESUMO
A criação do Sistema Único de Saúde (SUS) no Brasil, em 1988, representou avanços na organização sistêmica e descentralização da gestão única; entretanto, passados 30 anos, a governança de resultados parece frágil. A Nova Gestão Pública tem exigido esforços de monitoramento de resultados, controladoria e responsabilização dos gastos (accountability). Este estudo estuda as bases de modelos teóricos-conceituais (framework) de avaliação de desempenho e resultados aplicado nas instituições de saúde no Brasil e explora a translação de conhecimentos de uma amostra de gestores e profissionais (stakeholders), para validação de um painel de indicadores do SUS. Estabeleceu-se como objetivo estudar o conhecimento existente e validar algumas dimensões e indicadores de performance em serviços e unidades de saúde, por meio de painéis colaborativos com 220 gestores e profissionais de saúde em fases sucessivas (painel de especialistas, grupos Delphi e pesquisa de campo) captou-se o nível de
\end{abstract}

conhecimento e valorações de gestores na avaliação do SUS. A aplicação dos instrumentos de captação e validação das percepções obteve resultados das três fases iniciais $(n=108)$ que consolidaram um instrumento aplicado para validação de campo ( $n=112)$, cuja análise descritiva validou cinco 5 dimensões e 24 indicadoreschave para gestão de resultados em organizações de saúde. A análise inferencial gerou um modelo final que garantiu confiabilidade e validade das cinco 5 dimensões (macrodomínios), mas apenas de 17 indicadores (domínios) de desempenho propostos pelos decisores a partir de seus conhecimentos prévios.

\section{Palavras-chave:}

Governança; Avaliação em Saúde;

Avaliação de Processos e Resultados (cuidado de saúde); Indicadores Básicos de Saúde; Monitoramento.

\begin{abstract}
The creation of the Unified Health System (SUS) in Brazil in 1988 represented advances in the systemic organization and decentralization of the unified management; however, after 30 years the governance of results seems fragile. The New Public Management has demanded efforts to monitor results, control, and accountability. This study studies the bases of theoretical-conceptual models (framework) of performance assessment and results applied to health institutions in Brazil and explores the translation of knowledge from a sample of managers and professionals (stakeholders), for validation of a panel of SUS indicators. It is established as an objective to study or existing knowledge and to validate some dimensions and performance indicators in health services and units, by means of collaborative painéis with 220 managers and health professionals in successive phases (panel of specialists, Delphi groups and field research) Capture the level of knowledge and appraisals of managers in the SUS appraisal. The application of perceptual
\end{abstract}

capture instruments and validation instrumentsof perceptions yielded results from the three initial phases $(n=108)$, which consolidated an instrument validated for field validation ( $n=112)$, whose descriptive analysis validated five dimensions and 24 key indicators for management of results in health organizations. Inferential analysis generated a final model that guaranteed reliability and validity of the five dimensions (macrodomainsmacro-domains), but only 17 performance indicators (domains) proposed by the decision makers based on their previous knowledge.

Keywords:

Governance. Process and Results Evaluation (health care). Health Assessment. Basic Health Indicators. Monitoring 


\section{INTRODUÇÃO}

A criação do Sistema Único de Saúde (SUS) em 1988, no Brasil, representou avanços do ponto de vista de garantias de atendimento, da organização sistêmica e da descentralização da gestão única; porém, com frágil governança de desempenho. Por sua vez, a Nova Gestão Pública (NGP), ou Gerencialismo, tem exigido dos gestores públicos de saúde esforços de monitoramento de resultados, controladoria e responsabilização (accountability) dos gastos e recursos públicos.(MOITA; RAPOSO; BARBOSA, 2018; 2019a; b). Alinhados com a visão da NGP ou Gerencialismo, pode-se citar exemplos de projetos de avaliação e monitoramento de resultados da administração pública como PRODEV 1 e P4R $(\mathrm{P} f o r R)^{2}$, que têm sido implantados na gestão pública de países em desenvolvimento, inclusive no Brasil, por meio de agências internacionais de fomento em busca de otimizar os recursos e garantir a qualidade às ações de órgãos públicos (MOITA, 2019a).

No caso da saúde, o elevado volume de recursos aplicados, por si, exige avanços no monitoramento de resultados. Dados relativos a 2016 apontam que 35 países da Organização para a Cooperação e Desenvolvimento Econômico (OCDE) gastam em torno de 9,0\% do PIB no sistema de saúde, nos Estados Unidos cerca de 17,2\%, em Portugal 8,9\% e no Brasil 6,2\% (OECD, 2017). Além disso, os gastos com a saúde têm crescido nos últimos anos (2003-2016) em média 3,6\% nesses países (OECD, 2017). Nesta perspectiva, este estudo optou por uma abordagem integrada do monitoramento e avaliação, que aborda o processo de análises aprofundadas de dados e situações, pertinentes para a tomada de decisão e gestão baseada em resultados (UNDP, 2009). Assume-se, ainda, o escopo instrumental do monitoramento de resultados definido no âmbito da OECD, que trata o monitoramento como a função contínua que usa a recolha sistemática de dados, para fornecer à gestão e aos decisores (stakeholders) parâmetros decisores sobre uma intervenção em curso, por meio de indicadores específicos sobre a extensão do progresso, do atingimento dos objetivos e dos progressos alcançados na utilização de recursos alocados (HURST, 2000; MORRA IMAS; RIST, 2009; OECD, 2001). Norteia este estudo a tendência emergente na gestão de resultados em saúde (ALMEIDA, 1999; VIACAVA; ALMEIDA; CAETANO; FAUSTO et al., 2004).

As origens do campo da avaliação, segundo Alkin (2004), encontram-se no atendimento de duas necessidades: a prestação de contas e o controle dos programas. Uma visão complementar é a de Patton (1997) que propôs a avaliação enquanto metodologia focada na utilização dos resultados para a tomada de decisão. Chianca e Youker (2004) reforçam o interesse de avaliação da saúde da América Latina e Caribe.

Na Figura 1, sintetizou-se o arranjo organizacional de governação dos sistemas subsistema público (SUS) correlacionando o subsistema suplementar e privado e suas inter-relações interorganizações, alinhados com Lobato et al. (2016) sobre a intrincada relação entre os setores público e privado do sistema de saúde brasileiro.

\footnotetext{
1 PRODEV - Programa de Estratégia e Plano de Ação para a Efetividade do Desenvolvimento do BID para os países da América Latina e Caribe

2 PforR ou P4R - Programa para Resultados do Banco Mundial para o apoio ao desenvolvimento da "accountability" de países em desenvolvimento
} 
Figura 1 - 0 arranjo organizacional e as inter-relações do sistema público e privado de saúde do Brasil.

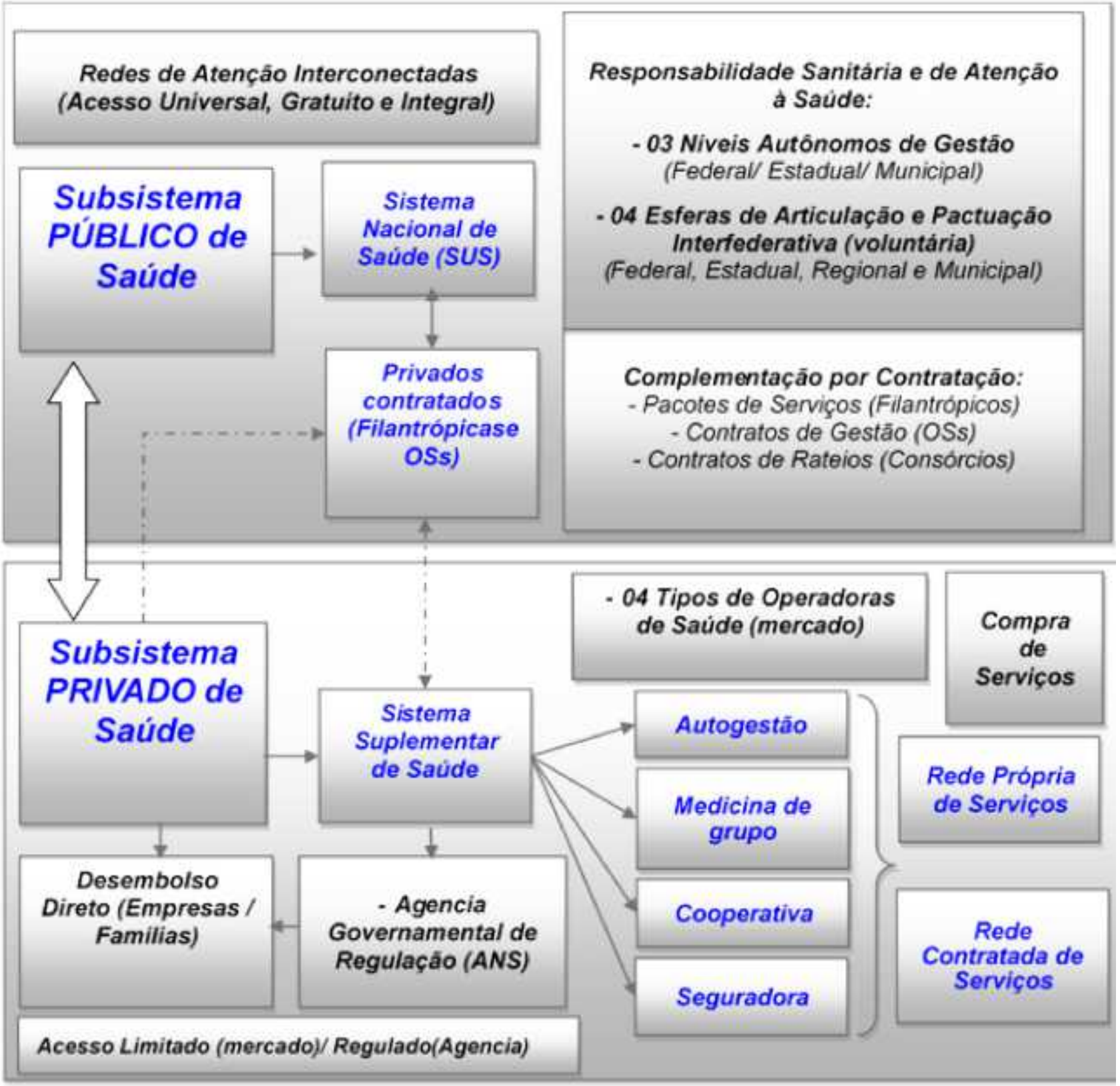

Fonte: Elaboração própria a partir de (MOITA, 2019c)

No âmbito das políticas sociais do Brasil, nota-se que a gestão das redes de serviços prioriza a implantação de novas estruturas de atendimentos, mas com gestão deficiente. Essa evolução no Brasil, gerou pelo menos sete modelos diferentes de gestão de unidades de saúde e hospitais: administração pública direta, administração pública indireta (autarquias, outros), consórcios públicos de saúde, fundações públicas e privadas, contratualização com organizações sem fins lucrativos (entidades filantrópicas e organizações sociais), e com empresas privadas especializadas no ramo de saúde (BRASIL, 2015) e, a tendência de parceria público e privada (PPP).

Essa multiplicidade de perspectivas nos modelos gerenciais coexistentes do sistema de saúde do Brasil, além das diversidades de escopos, geram complexidades inerentes aos diferentes modelos gerenciais, que por sua vez, agregam desafios crescentes para a avaliação e monitoramento de resultados no sistema de saúde. 
Não há na literatura um consenso sobre escopo e amplitude da avaliação e do monitoramento em saúde, mas existem muitos possíveis quadros teóricos conceituais relevantes (MOITA, 2019b; c) pelo que Arah et al. (2003) apresentam as abordagens de quadro teórico-conceitual (framework) dos sistemas de medição de performance do Reino Unido (NHS), do Canadá, da Austrália e dos EUA.

No âmbito do SUS, nota-se que a gestão das redes de serviços prioriza a implantação de novas estruturas de atendimentos e quase nunca em gestão da performance desses serviços de saúde, ou monitoramento de resultados das políticas, programas ou organizações de saúde. No SUS, há iniciativas incipientes de avaliação em programas de saúde. Moita (MOITA, 2019b; c), sintetizou as características de alguns relevantes sistemas mundiais de avaliação em saúde aplicáveis ao SUS.

Assim é importante estudar as bases de modelos teóricos-conceituais (framework) de avaliação de desempenho e resultados aplicado nas instituições de saúde no Brasil. No âmbito do SUS, nota-se que a gestão das redes de serviços prioriza a implantação de novas estruturas de atendimentos, sendo incipientes as iniciativas em gestão da performance desses serviços de saúde, ou monitoramento de resultados das políticas, programas ou organizações de saúde.

Em busca de desenvolver um quadro teórico-conceitual de avaliação de performance para organizações de saúde, aplicável às unidades do SUS, este estudo analisou algumas metodologias de mensuração de resultados em saúde no cenário mundial, além de uma pesquisa integrativa dos principais modelos aplicados no Brasil, especialmente quanto aos quadros de dimensões e indicadores prevalentes na literatura.

Diante desse contexto, surge a problematização central desta investigação: em um ambiente de escassez de metodologias e instrumentos validados de mensuração de performance em saúde, qual a importância relativa dos indicadores e dimensões de desempenho e resultados para a estruturação de quadros teóricos-conceituais (framework) e seus fatores mediadores na validação e consolidação de um proxy de painel de indicadores multidimensionais aplicados em saúde pública no Brasil?

No âmbito do SUS, justifica-se a importância deste estudo avaliativo, pois a avaliação é vista não só como instrumento para verificar a efetividade de programas, mas utilizada também com o intuito de melhorar a qualidade dos serviços por um processo de julgamento de valor orientado para a tomada de decisão e governança (RAPOSO, 2007).

Dessa forma, abordou-se o campo da avaliação além de algumas perspectivas do modelo lógico para estabelecer uma metodologia de análise e validação de resultados e, por fim, propôs-se as considerações finais.

\section{AVALIAÇÃO EM SAÚDE E O MODELO TEÓRICO-LÓGICO}

Os primórdios da avaliação em saúde são citados em (DOS REIS; DOS SANTOS; DE CAMPOS; ACURCIO et al., 1990), nos trabalhos de Flexner (FLEXNER, 1910) e no relatório Codman (PORTERFIELD, 1976), com uma proposta de metodologia de avaliação de rotina do estado de saúde dos pacientes hospitalares, para estabelecer os resultados finais das intervenções médicas. Também se destaca a criação do embrião da Joint Commission on Accreditation of Healthcare Organizations (JCAHO), em 1928, uma das principais agências mundiais de fomento à qualidade no setor de saúde.

O aumento indiscriminado de custos da área médica e a necessidade do controle da qualidade da assistência médica pressionam os sistemas de saúde para uma adequada gestão dos recursos (DOS 
REIS; DOS SANTOS; DE CAMPOS; ACURCIO et al., 1990 , p. 51; PEREZ ARIAS; FELLER, 1983). Esses autores ainda argumentam que "estas são razões suficientes para se buscar o controle dos custos e da qualidade a atenção médica, e que a tendência ao aumento dos custos do setor saúde é, na verdade, universal".

Alkin (2004, apud; SAMICO; FELISBERTO; FIGUEIRÓ; FRIAS, 2010) estabelece as origens do campo da avaliação a partir de duas necessidades: a prestação de contas (accountability) e o controle dos programas.

Segundo Samico et al. (2010), o campo de avaliação em saúde engloba uma diversidade de termos, conceitos e métodos conforme sua heterogeneidade, complexidade e subjetividade das intervenções, sejam elas ações, serviços, programas ou políticas públicas, por isso é um dilema a seleção de um modelo ou abordagem de avaliação(WORTHEN; SANDERS; FITZPATRICK, 2004).

A partir da proposta inicial de Avendis Donabedian (1980) - Avaliação de Estrutura, Processos e Resultados -, há uma busca por modelos integrativos, em que se avaliam as relações entre estado de saúde, qualidade do cuidado e gastos de recursos. Também se pode citar o modelo de Brook \& Lohr (1985) e de (DOS REIS; DOS SANTOS; DE CAMPOS; ACURCIO et al., 1990), que propõe a avaliação das dimensões: eficácia do cuidado, efetividade do cuidado, as variações das características populacionais e os níveis de qualidade de cuidado.

Por sua vez, Chianca e Youker (2004) registram um crescente interesse no campo de avaliação de sistemas de saúde da América Latina e Caribe. No entanto, Bosi e Mercado (2006) elaboram uma extensa revisão de literatura quanto às experiências de avaliação nos países da América Latina e concluem que a maioria dos trabalhos é de índole teórica, sendo poucos os estudos empíricos ou de caso. Citam ainda que quase sempre os enfoques avaliativos usados se inspiram em certos autores e obras eurocêntricas (FALS BORDA; MORA-OSEJO, 2004), do mundo anglo-saxão, em especial, provenientes das teorias e modelos emergentes da península ibérica (BOSI; MERCADO, 2006). Assim, o campo de avaliação em saúde, por suas complexidades, subjetividades e múltiplas perspectivas, engloba uma diversidade de termos, conceitos e métodos, o que está coerente com a multiplicidade de questões consideradas como pertinentes na área da saúde, na heterogeneidade e complexidade das intervenções, sejam elas ações, serviços, programas ou políticas públicas.

Em uma breve análise dos aspectos filosóficos da avaliação, escolheu-se trabalhar sob as bases da ontologia idealista, na qual os modelos e representações que formam o nível empírico são contingentes e socialmente produzidos - neste caso, pelos agentes de decisão chaves (BOSI; MERCADO, 2006).

Destaca-se, ainda, os aspectos de aplicabilidade da avaliação para a tomada de decisão em saúde no Brasil, como nos exemplos dos relatos de Tanaka e Tamaki (2012), de Contandriopoulos (2006), de Fernandes, Ribeiro e Moreira (2011), de Campos e Furtado (2011) e alguns outros estudos iniciais aplicados no sistema de saúde do Brasil. De acordo com Travassos, Noronha e Martins (1999), é necessário destacar a importância do desenvolvimento de estratégias para permitir que os resultados das avaliações melhorem a efetividade dos cuidados hospitalares. Assim, o monitoramento de indicadores pode promover a efetividade da assistência, bem como da busca pela eficiência organizacional em saúde.

Segundo Raposo (2007), a avaliação é vista não só como instrumento para verificar a efetividade de programas, mas utilizada também com o intuito de melhorar a qualidade dos serviços. Sendo assim, a avaliação pode ser entendida como um processo de julgamento de valor orientado para a tomada de decisão e governança. 
A monitorização dos indicadores constitui também uma boa prática de governança hospitalar (RAPOSO, 2007), uma vez que reforçam a transparência e a prestação de contas/responsabilização (accountability). Entretanto, a multiplicidade de perspectivas e de complexidades envolvidas, além das diversidades de escopos e definições, demanda a análise dos principais quadros teóricos e metodológicos de avaliação relevantes da literatura.

De forma mais instrumental, pode-se citar ainda alguns quadros teóricos-conceituais como os projetos Quality Indicator Project (QIP) ${ }^{3}$ da Agência de Pesquisa e Qualidade nos Serviços de Saúde U.S. Agency for Healthcare Research and Quality (AHRQ) ${ }^{4}$, com destaque para o projeto da Fundação Europeia para Gerenciamento da Qualidade - European Foundation for Quality Management $(E F Q M)^{5}$, além de sistema de indicadores do Project Assessment Tool of Quality Improvement in Hospitals (PATH) ${ }^{6}$ da Organização Mundial de Saúde $(\mathrm{OMS})^{7}$. No Reino Unido, são duas as abordagens, a primeira baseada na definição de indicadores do Serviço Nacional de Saúde/NHS ${ }^{8}$, e a segunda interessada na concretização de uma metodologia para estabelecer "hospital ratings"; em Portugal, o Sinas@Hospitais ${ }^{9}$ apresenta-se sob a coordenação da Entidade Reguladora de Saúde $(E R S)^{10}$, que classifica os hospitais avaliados (ranking) e é utilizada pela Administração Central do Sistema de Saúde $(\mathrm{ACSS})^{11}$, entre outros.

Além disso, estudaram-se os projetos brasileiros como o Projeto Desenvolvimento de Metodologia de Avaliação do Desempenho do Sistema de Saúde Brasileiro (Proadess) ${ }^{12}$, indicadores do Índice de Desempenho do SUS (IDSUS) ${ }^{13}$, Indicadores e Dados Básicos da Saúde (IDB) ${ }^{14}$ da Rede Interagencial de Informações para a Saúde (RIPSA) e indicadores do novo Programa Nacional de Avaliação de Serviços de Saúde (PNASS). No âmbito da Agência Nacional de Saúde Suplementar (ANS), foram estudados Índices de Desempenho da Saúde Suplementar (IDSS) e indicadores Qualiss do Programa de Qualificação dos Prestadores de Serviços de Saúde Suplementar (Qualiss), em fase de estruturação; nas organizações privadas: indicadores Prohasa/CQH ${ }^{15}$ e indicadores Sipageh ${ }^{16}$.

No contexto brasileiro, uma revisão sistemática, voltada para avaliação de qualidade hospitalar, mostra que os primeiros estudos surgiram entre 1991 e 2003, tendo encontrado apenas 48 publicações (MACHADO; MARTINS; MARTINS, 2013). Em outro estudo sobre a avaliação em saúde no Brasil, acharam-se apenas 44 estudos (FERNANDES; RIBEIRO; MOREIRA, 2011).

\footnotetext{
3 QIP - Quality Indicator Project (Projeto de Indicadores de Qualidade)

4 AHRQ - U.S. Agency for Healthcare Research and Quality (Agência de Pesquisa e Qualidade nos Serviços de Saúde)

5 EFQM - European Foundation for Quality Management (Fundação Europeia para Gerenciamento da Qualidade)

6 PATH - Performance Assessment Tool for Quality Improvement in Hospitals (ferramenta de avaliação de performance para a melhoria da qualidade hospitalar)

7 OMS - Organização Mundial de Saúde (WHO), representada no Brasil, América Latina, e Caribe pela OPAS-Organização PanAmericana de Saúde.

8 NHS- National Health System (Serviço Nacional de Saúde do Reino Unido)

9 Sinas@Hospitais - Sistema de Indicadores de Performance de Hospitais do Serviço Nacional de Saúde de Portugal

10 ERS - Entidade Reguladora de Saúde que operacionaliza a regulação do sistema público e privado do SNS de Portugal

11 ACSS - Administração Central do Sistema Nacional de Saúde (SNS) de Portugal

12 PROADESS - Projeto Desenvolvimento de Metodologia de Avaliação do Desempenho do Sistema de Saúde Brasileiro

13 IDSUS - Matriz de indicadores em 18 macrodimensões gerenciada pelo DATASUS e o Ministério da Saúde do Brasil

14 IDB - Indicadores e Dados Básicos para a Saúde no Brasil gerenciados pela RIPSA e o Ministério da Saúde do Brasil

15 PROHASA/CQH - Indicadores do Programa de Estudos Avançados em Adm. Hospitalar e de Sistemas de Saúde da FMUSP

16 SIPAGEH - Sistema de Indicadores Padronizados para Gestão Hospitalar, com adesão voluntária de 37 hospitais do Sul do Brasil.
} 
Neste propósito, procedeu-se a uma revisão sistemática ampliada nas principais bases publicações de artigos científicos do Brasil (Scielo e Lilacs e Medline, via Biblioteca Virtual em Saúde - BVS), tendo localizado 112 publicações no período de 1990 a 2018, sendo apenas 12 produções na linha de avaliação de performance em saúde e somente dois artigos no campo da avaliação de qualidade percebida caracterizados, comprovando-se a incipiência de estudos e/ou publicações sobre o tema. Dessa forma, na Figura 2, sintetizou-se a seguinte classificação das publicações que evidenciam a importância desta investigação, conforme dados da pesquisa original (MOITA, 2019b; c; MOITA; RAPOSO; BARBOSA, 2019c; MOITA; RAPOSO; BARBOSA, 2020).

Destaca-se, ainda, que o período de 1999 a 2005 teve média de apenas uma publicação anual, entre 2006 e 2010 houve 39 produções, e entre 2011 e 2018 a média foi de quatro publicações anuais, sendo que após 2011 foram publicados 18 artigos, cinco monografias e oito teses, que mostram o nível de interesse pela avaliação em saúde.

Figura 2- Bibliometria de estudos de avaliação em saúde no Brasil (1990 - 2018)

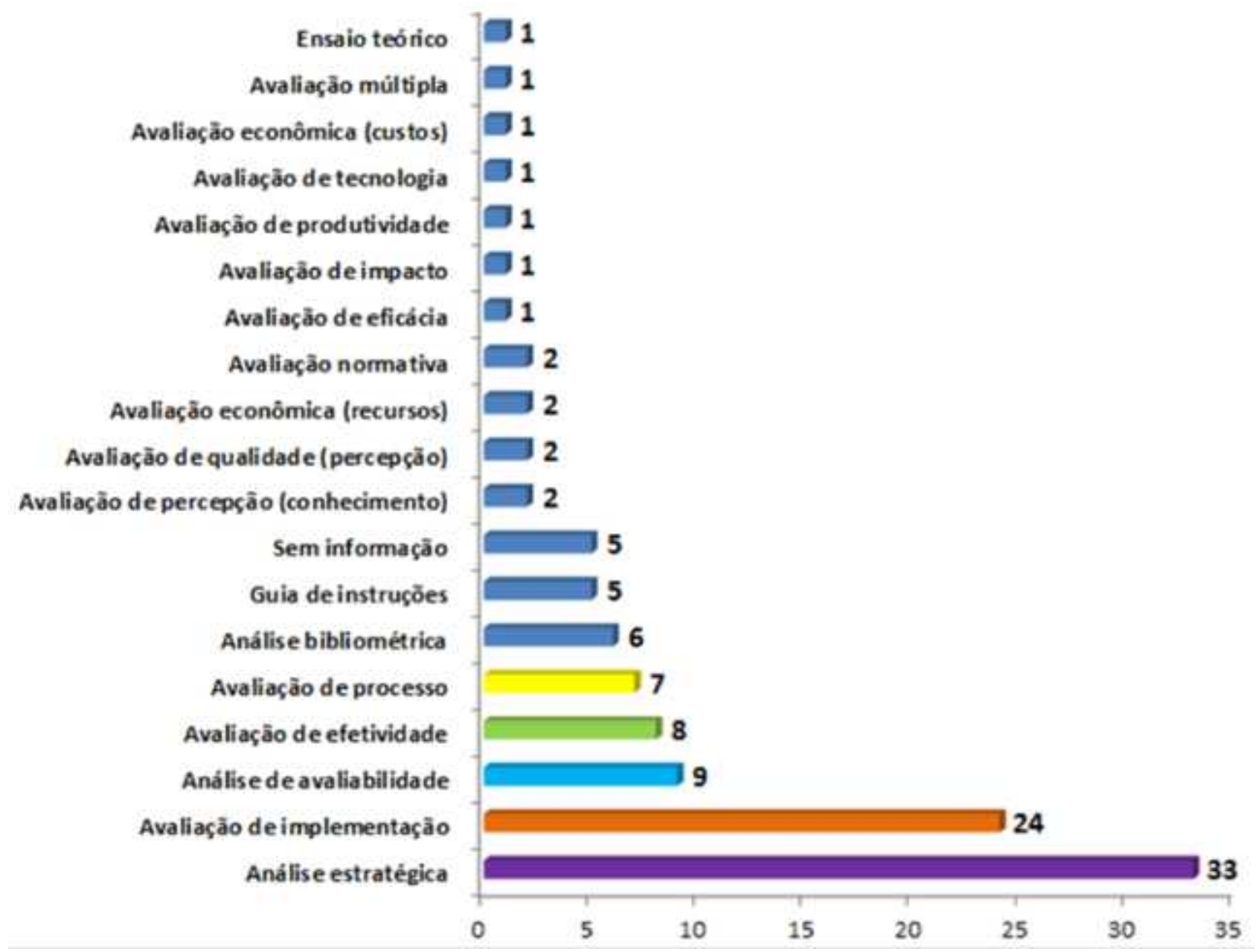

Fonte: elaboração própria

Em 2013, o IBGE aplicou a Pesquisa Nacional de Saúde (PNS) (SOUZA-JÚNIOR; FREITAS; ANTONACl; SZWARCWALD, 2015; SZWARCWALD; MALTA; PEREIRA; VIEIRA et al., 2014), uma extensa amostra de 
domicílios de todo o Brasil com perspectiva de performance do sistema de saúde e alguns dados clínicos populacionais (BOCCOLINI; BOCCOLINI; DAMACENA; FERREIRA et al., 2016; MALTA; SANTOS; STOPA; VIEIRA et al., 2016; NICO; ANDRADE; MALTA; JÚNIOR et al., 2016; PIOLA; DE FRANÇA; NUNES, 2016; VIACAVA; BELLIDO, 2016). A segunda edição na PNS foi aplicada em 2019, estando com resultados em análise e microdados em organização.

Em outra perspectiva, na saúde brasileira existem alguns sistemas informatizados, indicadores e instrumentos gerenciais no campo da saúde pública, tais como: indicadores do Datasus, Projeto Proadess, indicadores IDSUS, indicadores RIPSA e indicadores do novo PNASS. No âmbito da ANS, observam-se os Índices IDSS e indicadores Qualiss; e nas organizações privadas, constam os indicadores Prohasa/CQH e indicadores Sipageh. Infelizmente, nenhum desses quadros de indicadores tem sido usado de forma geral e permanente no SUS, possivelmente pela falta de legitimidade no uso.

Um estudo aplicado da (ROSALEM, 2013) apresentou um quadro integrativo do rol de indicadores das metodologias do $\mathrm{CQH}$, Prohasa, Sipageh e de três outras listas de indicadores de alguns órgãos e agências internacionais (ACHS - Australian Council on Healthcare Standards, CND - Canadá Health Indicators - 2003, HP - Health People 2010 - USA, NHS - National Health Security, RALC - Grupo para Reforma del Sector Salud en América Latina y Caribe-OPAS).

Por sua vez, no enquadramento dos estudos de governança organizacional, deve-se selecionar uma teoria de embasamento. Entre as diversas teorias de governança, pode-se destacar a teoria neoclássica, a teoria da agência, a teoria dos custos de transações, a teoria do direito à propriedade, dentre outras, sintetizadas no estudo de Alves (2012).

Há outras teorias que se destacam no âmbito da gestão pública, que não se distanciam desta investigação, por exemplo: a teoria da escolha pública (public chioce) e a teoria da provedoria (stewardship). Na síntese apresentada por Alves (2012) o autor destaca a teoria dos stakeholders com diversas vantagens para a gestão dos sistemas produtivos de bens e serviços públicos que se alinham com os objetivos deste estudo.

Ressalte-se que pesquisadores da teoria dos stakeholders sustentam que o conhecimento acerca da natureza dos stakeholders organizacionais constitui informação relevante para a previsão do comportamento organizacional (DÉNIZ-DÉNIZ; ZÁRRAGA-OBERTY, 2004; MELLAHI; WOOD, 2003). Segundo Freeman (1984), um stakeholder é qualquer indivíduo ou grupo que pode afetar ou ser afetado pelo alcance dos objetivos de uma organização.

Do ponto de vista teórico, há pelo menos quatro principais perspectivas com diferentes abordagens da ação dos stakeholders nas organizações: as visões instrumental, descritiva, normativa e de responsabilidade social (CARVALHO, 2007).

Portanto, para enfrentar essa multiplicidade de perspectivas sugere-se tomar por base a teoria dos stakeholders, em especial nas suas perspectivas descritiva e instrumental destacadas pela literatura (BRYSON, 2004; HART; SHARMA, 2004), em que os grupos de stakeholders podem efetivamente exercer um impacto considerável nos resultados organizacionais e sobre o seu desempenho e competitividade.

Por sua vez, metodologias e sistemas de indicadores de destaque no campo da saúde pública podem ser analisados e sistematizados de acordo com suas possíveis potencialidades, virtudes, limitações e 
desafios, para compor uma matriz de dimensões e de indicadores para avaliação e validação pelos agentes de decisão da amostra.

Dessa forma, nessa etapa, partiu-se da pesquisa integrativa realizada (MOITA, 2019b; c; MOITA; RAPOSO; BARBOSA, 2019c; MOITA; RAPOSO; BARBOSA, 2020) para estudar os modelos de avaliação de performance mais relevantes, mas não se selecionou nenhum modelo específico de avaliação de resultados, evitando confinamentos dos conhecimentos captados.

Na literatura há diversas propostas de quadro teórico-conceitual para avaliação de performance e a seleção de indicadores, por exemplo, painéis de dimensões de avaliação de desempenho e resultados usados para a medição da qualidade de alguns países e organizações multilaterais (Reino Unido, Canadá, Austrália, EUA, OMS e OCDE) citados como relevantes em outros importantes estudos (ARAH; CUSTERS; KLAZINGA, 2003; ARAH; KLAZINGA; DELNOIJ; ASBROEK et al., 2003; ARAH; WESTERT; HURST; NIEK et al., 2006). Outro destaque é o quadro teórico-conceitual proposto pela Organização Mundial de Saúde (OMS), chamado projeto PATH, que está baseado em competências profissionais na aplicação do conhecimento atual, tecnologias e recursos disponíveis; eficiência no uso de recursos; risco mínimo para o paciente; responsividade ao paciente; contribuição ótima para os resultados de saúde (VEILLARD; CHAMPAGNE; KLAZINGA; KAZANDJIAN et al., 2005).

Por sua vez, Papanicolas \& Smith (2010) comparam dez abordagens destacadas na literatura de quadro teórico-conceitual (framework) de sistemas de saúde e as classificam segundo estas três categorias, além de expor as limitações de cada um dos dez modelos estudados, sendo nove deles assinalados também como quadro teórico-conceitual (framework) de avaliação de desempenho de sistemas de saúde, exceto o modelo behavioural health care (Quadro 1).

Quadro 1 - Quadro de objetivos versus quadro teórico-conceitual (framework)

\begin{tabular}{|c|c|c|}
\hline Framework(nome) & Objetivo Intermediário & Objetivo Final \\
\hline $\begin{array}{c}\text { Framework for Assessing } \\
\text { Behavioural Healthcare(1998) }\end{array}$ & $\begin{array}{c}\text { Eficácia; Eficiência; } \\
\text { Equidade }\end{array}$ & Saúde e bem-estar \\
\hline EGIPSS model (1998) & $\begin{array}{c}\text { Produtividade; Volume de } \\
\text { cuidados e serviços: } \\
\text { Qualidade de cuidados e } \\
\text { serviços }\end{array}$ & $\begin{array}{c}\text { Melhoria da saúde; Eficácia; } \\
\text { Eficiência; Equidade }\end{array}$ \\
\hline WHO PerformanceFramework & $\begin{array}{c}\text { Acesso; Cobertura; } \\
\text { Qualidade; Segurança }\end{array}$ & $\begin{array}{c}\text { Nível e distribuição de saúde; Nível } \\
\text { e distribuição de capacidade de } \\
\text { resposta; Justiça no financiamento; } \\
\text { Eficiência }\end{array}$ \\
\hline $\begin{array}{c}\text { OECD PerformanceFramework } \\
\text { (2001) }\end{array}$ & $\begin{array}{c}\text { - Nível e distribuição de saúde; } \\
\text { Nível e distribuição decapacidade } \\
\text { de resposta e acesso; Equidade; } \\
\text { Eficiência macroeconômica e } \\
\text { microeconômica }\end{array}$ \\
\hline Control Knobs Framework(2003) & $\begin{array}{c}\text { Eficiência; Qualidade; } \\
\text { Acesso }\end{array}$ & $\begin{array}{c}\text { Estado de saúde; Satisfação do } \\
\text { usuário; Proteção contra riscos }\end{array}$ \\
\hline Commonwealth Fund Framework \\
(2006) & $\begin{array}{c}\text { Alta qualidade do cuidado; } \\
\text { Cuidado eficiente; Acesso; } \\
\text { Inovação e melhoria do } \\
\text { sistema e da força de } \\
\text { trabalho }\end{array}$ & $\begin{array}{c}\text { Vidas longas, saudáveis e } \\
\text { produtivas }\end{array}$ \\
\hline
\end{tabular}




\begin{tabular}{|c|c|c|}
\hline Framework (nome) & Objetivo Intermediário & Objetivo Final \\
\hline OECD HCQI Framework (2006) & $\begin{array}{c}\text { Melhoria da saúde; Eficiência } \\
\text { macroecon ômica (sustentabilidade) } \\
\text { e eficiência microecon ômica (valor } \\
\text { para o dinheiro); Equidade }\end{array}$ \\
\hline $\begin{array}{c}\text { WHO Building Blocks Framework } \\
\text { (2007) }\end{array}$ & $\begin{array}{c}\text { Nível e distribuição de saúde; Nível } \\
\text { e distribuição de capacidade de } \\
\text { resposta; Justiça no financiamento; } \\
\text { Eficiência }\end{array}$ \\
\hline $\begin{array}{c}\text { Qualidade; Segurança } \\
\text { Systems Framework (2008) }\end{array}$ & $\begin{array}{c}\text { Equidade; Escolha; } \\
\text { Eficiência; Eficácia }\end{array}$ & $\begin{array}{c}\text { Saúde; Proteção contra risco } \\
\text { financeiro; Satisfação do usuário }\end{array}$ \\
\hline N/A & N/A \\
\hline
\end{tabular}

Fonte: adaptado de Papanicolas e Smith (2010: 33-35)

Há diversos quadros conceituais (framework) de avaliação de performance de sistemas de saúde e de indicadores aplicados à avaliação de políticas e de instituições de saúde. Assim, devido a complexidade de comparação preferiu-se apresentar algumas experiências selecionadas por sua relevância, a seguir:

Destaca-se a comparação do sistema de performance do Reino Unido (NHS) com os dos sistemas de saúde do Canadá, da Austrália e dos EUA, oferecida por Arah et al. (2003) que caracterizaram as bases conceituais e contextuais para a estruturação do quadro teórico (framework) dos sistemas de performance destes países, apresentados no Quadro 2.

Quadro 2 - Síntese dos quadros conceituais (frameworks) nacionais para o desempenho do sistema de saúde (países selecionados)

\begin{tabular}{|c|c|c|c|c|}
\hline Frameworks & Reino Unido & Canadá & Austrália & USA \\
\hline $\begin{array}{l}\text { Tipo de } \\
\text { sistema de } \\
\text { saúde }\end{array}$ & $\begin{array}{l}\text { Nacionalizado, mas com } \\
\text { responsabilidade } \\
\text { recentemente } \\
\text { desconcentrada; } \\
\text { financiamento público }\end{array}$ & $\begin{array}{l}\text { Federal, territorial e } \\
\text { provincial, com } \\
\text { princípios comuns; } \\
\text { financiamento misto, } \\
\text { mas principalmente } \\
\text { público }\end{array}$ & $\begin{array}{l}\text { Funções federadas, } \\
\text { nacionais e estaduais } \\
\text { compartilhadas; } \\
\text { operacionalizada } \\
\text { pelo setor público e } \\
\text { privado; } \\
\text { financiamento misto }\end{array}$ & $\begin{array}{l}\text { Pluralista, com regulação } \\
\text { estadual e federal } \\
\text { combinada; } \\
\text { operacionalizada pelo } \\
\text { setor privado; } \\
\text { financiamento misto, mas } \\
\text { principalmente privado }\end{array}$ \\
\hline $\begin{array}{l}\text { Quadro de } \\
\text { desempenho }\end{array}$ & $\begin{array}{l}\text { Quadro teórico-conceitual } \\
\text { nacional coerente, com um } \\
\text { conjunto abrangente de } \\
\text { indicadores e metas } \\
\text { visando seis áreas de } \\
\text { desempenho; uso local } \\
\text { multidirecional de PIs } \\
\text { (Indicadores de } \\
\text { performance) sendo } \\
\text { entrelaçados. }\end{array}$ & $\begin{array}{l}\text { Quadro teórico- } \\
\text { conceitual nacional } \\
\text { coerente, com } \\
\text { indicadores para a } \\
\text { saúde e o desempenho } \\
\text { dos sistemas de saúde; } \\
\text { apoiado por outros } \\
\text { para as características } \\
\text { da comunidade e do } \\
\text { sistema de saúde }\end{array}$ & $\begin{array}{l}\text { Evolução de } \\
\text { estrutura e } \\
\text { indicadores } \\
\text { nacionais coerentes; } \\
\text { abordagem de nove } \\
\text { dimensões; } \\
\text { monitoramento de } \\
\text { entradas, saídas e } \\
\text { resultados }\end{array}$ & $\begin{array}{l}\text { Fraca coerência da } \\
\text { abordagem nacional; } \\
\text { propuseram um quadro } \\
\text { de desempenho de seis } \\
\text { domínios; conjunto } \\
\text { robusto de indicadores } \\
\text { operacionais (ou seja, } \\
\text { usados localmente ou } \\
\text { específicos do plano de } \\
\text { cuidados de saúde) }\end{array}$ \\
\hline
\end{tabular}




\section{Continuação}

\begin{tabular}{|c|c|c|c|c|}
\hline Frameworks & Reino Unido & Canadá & Austrália & USA \\
\hline $\begin{array}{l}\text { Base } \\
\text { conceitual } \\
\text { para o quadro } \\
\text { teórico } \\
\text { (framework) }\end{array}$ & $\begin{array}{l}\text { Baseado em uma } \\
\text { abordagem de balanced } \\
\text { scorecard, para ser } \\
\text { reportado como um } \\
\text { sistema de classificação de } \\
\text { estrelas de desempenho }\end{array}$ & $\begin{array}{l}\text { 'Iniciativa do Roteiro' } \\
\text { para melhorar a } \\
\text { qualidade, utilização, } \\
\text { comparabilidade, } \\
\text { disseminação de } \\
\text { informação e } \\
\text { funcionamento do } \\
\text { sistema de saúde }\end{array}$ & $\begin{array}{l}\text { Conceito relacional } \\
\text { de três níveis para } \\
\text { refletir o impacto do } \\
\text { desempenho do } \\
\text { sistema e dos } \\
\text { determinantes de } \\
\text { saúde no estado de } \\
\text { saúde e nos } \\
\text { resultados }\end{array}$ & $\begin{array}{l}\text { Quadro teórico } \\
\text { (framework) dependente } \\
\text { do comprador e da } \\
\text { qualidade de gestão; } \\
\text { apoiado por um modelo } \\
\text { de saúde da população e } \\
\text { por relatórios de } \\
\text { desempenho orientados } \\
\text { para o paciente }\end{array}$ \\
\hline $\begin{array}{l}\text { Melhoria de } \\
\text { desempenho } \\
\text { ("mecanismo } \\
\text { de mudança") }\end{array}$ & $\begin{array}{l}\text { Controles de garantias, } \\
\text { prestação de contas e uso } \\
\text { de indicadores de } \\
\text { benchmarking, Incentivos } \\
\text { financeiros; 'Autonomia } \\
\text { conquistada' }\end{array}$ & $\begin{array}{l}\text { Benchmarking, } \\
\text { prestação de contas, } \\
\text { planejamento e } \\
\text { medição; premissa em } \\
\text { sistema de informação } \\
\text { de saúde de alta } \\
\text { qualidade }\end{array}$ & $\begin{array}{l}\text { Profissionalismo } \\
\text { (com práticas de } \\
\text { benchmarking), } \\
\text { accountability } \\
\text { (prestação de contas } \\
\text { e resultados) e } \\
\text { dinâmica de } \\
\text { mercado; uso local } \\
\text { de incentivos } \\
\text { financeiros }\end{array}$ & $\begin{array}{l}\text { Dinâmica do mercado (e, } \\
\text { mais recentemente, a } \\
\text { qualidade) por meio da } \\
\text { seleção e escolha de } \\
\text { compradores e } \\
\text { consumidores de serviços } \\
\text { de saúde }\end{array}$ \\
\hline $\begin{array}{l}\text { Iniciativas de } \\
\text { qualidade de } \\
\text { atendimento }\end{array}$ & $\begin{array}{l}\text { Qualidade como principal } \\
\text { prioridade nacional, } \\
\text { recentemente; governança } \\
\text { clínica (NSF, NICE, CHI, } \\
\text { NPSA, NPF) }\end{array}$ & $\begin{array}{l}\text { Melhoria contínua da } \\
\text { qualidade como } \\
\text { prioridade nos } \\
\text { serviços de saúde } \\
\text { (HC, CCHSA, NQI, } \\
\text { CMA) }\end{array}$ & $\begin{array}{l}\text { Parte integrada do } \\
\text { quadro teórico- } \\
\text { conceitual } \\
\text { (framework) de } \\
\text { desempenho do } \\
\text { sistema definido em } \\
\text { termos de qualidade } \\
\text { de atendimento } \\
\text { (NHPC, ACSQHC, } \\
\text { NHPAC, NICS) }\end{array}$ & $\begin{array}{l}\text { Relatórios de qualidade } \\
\text { de domínio público e } \\
\text { outras iniciativas } \\
\text { (QMQMR, IOM, AHRQ, } \\
\text { JCAHO, HEDIS) }\end{array}$ \\
\hline $\begin{array}{l}\text { Vínculo do } \\
\text { sistema de } \\
\text { desempenho } \\
\text { aos objetivos } \\
\text { (eficácia para } \\
\text { qualidade) } \\
\end{array}$ & $\begin{array}{l}\text { Garantir o acesso a } \\
\text { cuidados efetivos, } \\
\text { imediatos e de alta } \\
\text { qualidade }\end{array}$ & $\begin{array}{l}\text { Melhorar a promoção } \\
\text { da saúde, o acesso, a } \\
\text { eficácia do sistema e a } \\
\text { qualidade }\end{array}$ & $\begin{array}{l}\text { Definir o } \\
\text { desempenho } \\
\text { explicitamente em } \\
\text { termos de qualidade } \\
\text { e eficácia entre } \\
\text { outras dimensões } \\
\end{array}$ & $\begin{array}{l}\text { Melhorar a eficácia de } \\
\text { todo o sistema e a } \\
\text { qualidade dos processos e } \\
\text { resultados de cuidados; } \\
\text { política nacional em } \\
\text { evolução }\end{array}$ \\
\hline $\begin{array}{l}\text { Metas } \\
\text { gerenciais }\end{array}$ & $\begin{array}{l}\text { Refletir a necessidade de } \\
\text { governança corporativa, } \\
\text { usando foco em } \\
\text { benchmarking }\end{array}$ & $\begin{array}{l}\text { Permitir a tomada de } \\
\text { decisão oportuna, } \\
\text { flexível e correta em } \\
\text { todos os níveis; gestão } \\
\text { integrada }\end{array}$ & $\begin{array}{l}\text { Informar a tomada } \\
\text { de decisões, } \\
\text { assegurando a } \\
\text { pontualidade dos } \\
\text { relatórios de } \\
\text { desempenho }\end{array}$ & $\begin{array}{l}\text { Facilitar o acesso a } \\
\text { informações e relatórios } \\
\text { públicos; compensando } \\
\text { as falhas do mercado }\end{array}$ \\
\hline
\end{tabular}

Fonte: adaptado de (ARAH; KLAZINGA; DELNOIJ; ASBROEK et al., 2003)

Outro destaque é o quadro teórico-conceitual (framework) proposto pelo PATH que está baseado em competências profissionais na aplicação do conhecimento atual, tecnologias e recursos disponíveis; eficiência no uso de recursos; risco mínimo para o paciente; responsividade ao paciente; contribuição ótima para os resultados de saúde (VEILLARD; CHAMPAGNE; KLAZINGA; KAZANDJIAN et al., 2005).

O projeto PATH foi desenvolvido por meio de uma série de quatro oficinas e reuniu peritos dętadRu mundo, com reconhecidas experiências na avaliação de performance hospitalar (VEILLARD; 
CHAMPAGNE; KLAZINGA; KAZANDJIAN et al., 2005). Uma extensa revisão da literatura sobre projetos de performance hospitalar foi realizada, mais de 100 indicadores de desempenho foram analisados e um inquérito foi realizado em 20 países europeus.

Em um primeiro momento, o projeto PATH teve uma fase piloto de implementação em hospitais de oito países para aperfeiçoar o seu quadro de dimensões e indicadores de performance, antes de uma maior abrangência (VEILLARD, 2012). O projeto PATH conta com duas listas de indicadores: um conjunto operacional com 24 indicadores principais de desempenho e um conjunto personalizado de 27 indicadores (VEILLARD; CHAMPAGNE; KLAZINGA; KAZANDJIAN et al., 2005: 492). O conjunto principal de indicadores de performances, distribuídos em 20 dimensões de avaliação, sintetizados no Quadro 3, foi projetado para permitir benchmarking em diferentes contextos mundiais e os personalizados devem adequar-se de forma flexível às diferentes realidades de cada país (VEILLARD; CHAMPAGNE; KLAZINGA; KAZANDJIAN et al., 2005: 493-95).

Quadro 3 - Conjunto principal dos 27 indicadores de desempenho do hospital (projeto PATH)

\begin{tabular}{|c|c|c|c|}
\hline $\begin{array}{c}\text { Dimensões } \\
\text { (subdimensões) }\end{array}$ & $\begin{array}{l}\text { Indicadores de } \\
\text { desempenho }\end{array}$ & Numerador & Denominador \\
\hline $\begin{array}{l}\text { 1. Eficácia clínica e } \\
\text { segurança; }\end{array}$ & Parto cesariana & $\begin{array}{l}\text { Número total de casos (no } \\
\text { denominador) com parto cesariana }\end{array}$ & $\begin{array}{l}\text { Número total de } \\
\text { entregas (parto } \\
\text { cesariana) }\end{array}$ \\
\hline \multicolumn{4}{|l|}{$\begin{array}{l}\text { 2. Adequação do } \\
\text { cuidado; }\end{array}$} \\
\hline $\begin{array}{l}\text { 3. Conformidade de } \\
\text { processos de } \\
\text { cuidado) }\end{array}$ & $\begin{array}{l}\text { Rastreadores de uso } \\
\text { profilático de } \\
\text { antibióticos: resultados } \\
\text { da auditoria de } \\
\text { adequação }\end{array}$ & $\begin{array}{l}\text { Versão 1: Número total de registros } \\
\text { médicos auditados com evidência de } \\
\text { uso excessivo de antibióticos (muito } \\
\text { cedo e/ou muito longo, dose muito } \\
\text { alta, espectro muito amplo) em } \\
\text { comparação com as diretrizes dos } \\
\text { hospitais. } \\
\text { Versão 2: Número total de registros } \\
\text { médicos auditados com evidência de } \\
\text { subutilização de antibióticos (muito } \\
\text { cedo e/ou muito longo, dose muito } \\
\text { alta, espectro muito amplo) em } \\
\text { comparação com as diretrizes dos } \\
\text { hospitais }\end{array}$ & $\begin{array}{l}\text { Número total de } \\
\text { prontuários auditados } \\
\text { para um procedimento } \\
\text { operatório específico } \\
\text { rastreado }\end{array}$ \\
\hline $\begin{array}{l}\text { 4. Resultados dos } \\
\text { processos de cuidado } \\
\text { e segurança }\end{array}$ & $\begin{array}{l}\text { Mortalidade para } \\
\text { condições e } \\
\text { procedimentos } \\
\text { selecionados rastreados }\end{array}$ & $\begin{array}{l}\text { Número total de casos (no } \\
\text { denominador) que morreram } \\
\text { durante a internação }\end{array}$ & $\begin{array}{l}\text { Número total de } \\
\text { pacientes admitidos } \\
\text { para uma condição ou } \\
\text { procedimento } \\
\text { específico rastreado }\end{array}$ \\
\hline Idem (4) & $\begin{array}{l}\text { Readmissão para } \\
\text { condições e } \\
\text { procedimentos } \\
\text { selecionados rastreados }\end{array}$ & $\begin{array}{l}\text { Número total de casos (no } \\
\text { denominador) que foram admitidos } \\
\text { por meio do departamento de } \\
\text { emergência após a alta - dentro de } \\
\text { um período de acompanhamento } \\
\text { fixo - do mesmo hospital e com um } \\
\text { diagnóstico de readmissão relevante } \\
\text { para o atendimento inicial }\end{array}$ & $\begin{array}{l}\text { Número total de } \\
\text { pacientes admitidos } \\
\text { por uma condição ou } \\
\text { procedimento } \\
\text { selecionados } \\
\text { rastreados }\end{array}$ \\
\hline
\end{tabular}




\section{Continuação}

\begin{tabular}{|c|c|c|c|}
\hline $\begin{array}{c}\text { Dimensões } \\
\text { (subdimensões) }\end{array}$ & $\begin{array}{l}\text { Indicadores de } \\
\text { desempenho }\end{array}$ & Numerador & Denominador \\
\hline $\operatorname{Idem}(4)$ & $\begin{array}{l}\text { Admissão após cirurgia } \\
\text { no dia para } \\
\text { procedimentos } \\
\text { selecionados rastreados }\end{array}$ & $\begin{array}{l}\text { Número de casos (no denominador) } \\
\text { que tiveram uma admissão durante a } \\
\text { noite }\end{array}$ & $\begin{array}{l}\text { Número total de } \\
\text { pacientes que } \\
\text { realizaram uma } \\
\text { cirurgia / } \\
\text { procedimento } \\
\text { realizado na instalação } \\
\text { do procedimento } \\
\text { diurno ou com } \\
\text { intenção de alta de um } \\
\text { dia }\end{array}$ \\
\hline $\operatorname{Idem}(4)$ & $\begin{array}{l}\text { Retorno a um nível } \\
\text { mais alto de } \\
\text { atendimento (por } \\
\text { exemplo, de cuidados } \\
\text { agudos para intensivos) } \\
\text { para condições e } \\
\text { procedimentos } \\
\text { selecionados, em } 48 \\
\text { horas }\end{array}$ & $\begin{array}{l}\text { Número total de pacientes (no } \\
\text { denominador) que são } \\
\text { inesperadamente (uma ou várias } \\
\text { vezes) transferidos para um nível } \\
\text { mais elevado de cuidados (terapia } \\
\text { intensiva ou cuidados } \\
\text { intermediários) dentro de } 48 \text { horas } \\
\text { (ou } 72 \text { horas para contabilizar o } \\
\text { efeito de fim de semana) do alto } \\
\text { nível de atendimento a uma } \\
\text { enfermaria de cuidados agudos. }\end{array}$ & $\begin{array}{l}\text { Número total de } \\
\text { pacientes internados } \\
\text { em unidade de terapia } \\
\text { intensiva ou cuidados } \\
\text { intermediários }\end{array}$ \\
\hline $\operatorname{Idem}(4)$ & Eventos sentinela & $\begin{array}{l}\text { Variável binária A: Existência de } \\
\text { um procedimento formal para } \\
\text { registrar eventos sentinela. } \\
\text { Variável binária B: Existência de } \\
\text { um procedimento formal para atuar } \\
\text { sobre eventos sentinela + descrição } \\
\text { de procedimentos }\end{array}$ & \\
\hline $\begin{array}{l}\text { 5. Eficiência } \\
\text { (Adequação dos } \\
\text { serviços) }\end{array}$ & $\begin{array}{l}\text { Cirurgia- dia, para } \\
\text { procedimentos de } \\
\text { selecionados rastreados }\end{array}$ & $\begin{array}{l}\text { Número total de pacientes } \\
\text { submetidos a um procedimento } \\
\text { rastreado que o realizaram na } \\
\text { instalação do procedimento diurno }\end{array}$ & \\
\hline 6. Produtividade & $\begin{array}{l}\text { Tempo de permanência } \\
\text { para procedimentos } \\
\text { selecionados rastreados }\end{array}$ & $\begin{array}{l}\text { Mediana do tempo de permanência } \\
\text { no número de dias de internação } \\
\text { (dia de admissão e alta contam } \\
\text { como } 1 \text { dia) }\end{array}$ & \\
\hline 7. Uso de capacidade & $\begin{array}{l}\text { Inventário em estoque, } \\
\text { para produtos } \\
\text { farmacêuticos }\end{array}$ & $\begin{array}{l}\text { Valor total do estoque (no final do } \\
\text { ano) para produtos farmacêuticos }\end{array}$ & $\begin{array}{l}\text { Despesas totais para } \\
\text { produtos } \\
\text { farmacêuticos durante } \\
\text { o ano / } 365\end{array}$ \\
\hline Idem (7) & $\begin{array}{l}\text { Intensidade do uso de } \\
\text { sala de recuperação } \\
\text { cirúrgica }\end{array}$ & $\begin{array}{l}\text { Número de horas do paciente sob } \\
\text { anestesia }\end{array}$ & $\begin{array}{l}\text { Número de sala de } \\
\text { recuperação cirúrgica } \\
\text { nas } 24 \text { h }\end{array}$ \\
\hline $\begin{array}{l}\text { 8. Orientação da equipe } \\
\text { e segurança da } \\
\text { equipe }\end{array}$ & & & \\
\hline
\end{tabular}




\section{Continuação}

\begin{tabular}{|c|c|c|c|}
\hline $\begin{array}{c}\text { Dimensões } \\
\text { (subdimensões) }\end{array}$ & $\begin{array}{l}\text { Indicadores de } \\
\text { desempenho }\end{array}$ & Numerador & Denominador \\
\hline $\begin{array}{l}\text { 9. Perspectiva e } \\
\text { reconhecimento das } \\
\text { necessidades } \\
\text { individuais }\end{array}$ & Gastos com treinamento & $\begin{array}{l}\text { Custo direto para todas as atividades } \\
\text { dedicadas ao treinamento de pessoal }\end{array}$ & $\begin{array}{l}\text { Número médio de } \\
\text { empregados na folha } \\
\text { de pagamento durante } \\
\text { o período (alternativa: } \\
\text { número médio de } \\
\text { funcionários em tempo } \\
\text { integral) }\end{array}$ \\
\hline $\begin{array}{l}\text { 10. Promoção da saúde e } \\
\text { iniciativas de } \\
\text { segurança }\end{array}$ & $\begin{array}{l}\text { Despesas com } \\
\text { atividades de promoção } \\
\text { da saúde }\end{array}$ & $\begin{array}{l}\text { Custo direto de pessoal para todas } \\
\text { as atividades dedicadas à promoção } \\
\text { da saúde (conforme lista) } \\
\text { estabelecidas em } 2003\end{array}$ & $\begin{array}{l}\text { Número médio de } \\
\text { empregados na folha } \\
\text { de pagamento durante } \\
\text { o período (alternativa: } \\
\text { número médio de } \\
\text { funcionários em tempo } \\
\text { integral) }\end{array}$ \\
\hline $\begin{array}{l}\text { 11. Respostas } \\
\text { comportamentais }\end{array}$ & $\begin{array}{l}\text { Absenteísmo: } \\
\text { absenteísmo de curto } \\
\text { prazo }\end{array}$ & $\begin{array}{l}\text { Número de dias de ausência } \\
\text { justificada médica (ou não), por } 7 \\
\text { dias ou menos consecutivos, } \\
\text { excluindo feriados, entre } \\
\text { enfermeiras e auxiliares de } \\
\text { enfermagem }\end{array}$ & $\begin{array}{l}\text { Total equivalente em } \\
\text { tempo integral de } \\
\text { enfermeiros e } \\
\text { enfermeiros assistentes } \\
\text { (número dias } \\
\text { contratuais por ano } \\
\text { para uma equipe em } \\
\text { tempo integral, por } \\
\text { exemplo, 250) }\end{array}$ \\
\hline $\operatorname{Idem}(11)$ & $\begin{array}{l}\text { Absenteísmo: } \\
\text { absenteísmo a longo } \\
\text { prazo }\end{array}$ & $\begin{array}{l}\text { Número de dias de ausência } \\
\text { justificada médica (ou não) por } 30 \\
\text { dias ou mais, excluindo feriados, } \\
\text { entre enfermeiras e auxiliares de } \\
\text { enfermagem }\end{array}$ & $\begin{array}{l}\text { Total equivalente em } \\
\text { tempo integral de } \\
\text { enfermeiros e } \\
\text { enfermeiros assistentes } \\
\text { (número dias } \\
\text { contratuais por ano } \\
\text { para uma equipe em } \\
\text { tempo integral, por } \\
\text { exemplo, 250) }\end{array}$ \\
\hline 12. Segurança pessoal & Lesões percutâneas & $\begin{array}{l}\text { Número de casos de lesões } \\
\text { percutâneas relatados na base de } \\
\text { dados oficial ou medicina } \\
\text { ocupacional registrados em } 1 \text { ano } \\
\text { (inclui ferimentos por agulhas e } \\
\text { ferimentos por dispositivos } \\
\text { cortantes) }\end{array}$ & $\begin{array}{l}\text { Número médio de } \\
\text { funcionários } \\
\text { equivalentes em tempo } \\
\text { integral e médicos não } \\
\text { assalariados }\end{array}$ \\
\hline Idem (12) & $\begin{array}{l}\text { Tempo semanal de } \\
\text { trabalho de pessoal } \\
\text { excessivo }\end{array}$ & $\begin{array}{l}\text { Para cada semana, o número de } \\
\text { funcionários em tempo integral } \\
\text { (enfermeiros e auxiliares de } \\
\text { enfermagem) que trabalharam mais } \\
\text { de } 48 \text { horas, resumidos em todas as } \\
\text { semanas do períod o em estudo }\end{array}$ & $\begin{array}{l}\text { Número total de } \\
\text { semanas disponíveis } \\
\text { durante o período em } \\
\text { estudo (número total } \\
\text { de dias durante o } \\
\text { período - feriados de } \\
\text { estatuária), número de } \\
\text { funcionários em tempo } \\
\text { integral }\end{array}$ \\
\hline
\end{tabular}




\section{Continuação}

\begin{tabular}{|c|c|c|c|}
\hline $\begin{array}{c}\text { Dimensões } \\
\text { (subdimensões) }\end{array}$ & $\begin{array}{l}\text { Indicadores de } \\
\text { desempenho }\end{array}$ & Numerador & Denominador \\
\hline \multicolumn{4}{|l|}{$\begin{array}{l}\text { 13. Governança } \\
\text { responsiva e } \\
\text { segurança ambiental }\end{array}$} \\
\hline $\begin{array}{l}\text { 14. Integração e } \\
\text { continuidade do } \\
\text { sistema }\end{array}$ & $\begin{array}{l}\text { Pontuação média em } \\
\text { itens de continuidade } \\
\text { percebida em pesquisas } \\
\text { de pacientes }\end{array}$ & $\begin{array}{l}\text { O indicador é calculado com base } \\
\text { no questionário utilizado atualmente } \\
\text { no hospital. (Não é para } \\
\text { comparações internacionais e } \\
\text { nacionais, mas para } \\
\text { acompanhamento dentro da } \\
\text { organização. Se pesquisas padrão } \\
\text { são usadas em um país, o } \\
\text { benchmarking nacional é proposto) }\end{array}$ & \\
\hline $\begin{array}{l}\text { 15. Orientação em } \\
\text { Saúde Pública: } \\
\text { (Promoção da saúde; }\end{array}$ & $\begin{array}{l}\text { Aleitamento materno na } \\
\text { alta }\end{array}$ & $\begin{array}{l}\text { Número total de mães incluídas (no } \\
\text { denominador) na amamentação na } \\
\text { alta }\end{array}$ & $\begin{array}{l}\text { Número total de } \\
\text { entrega (mães em } \\
\text { amamentação) } \\
\text { preenchendo critérios } \\
\text { para inclusão }\end{array}$ \\
\hline $\begin{array}{l}\text { 16. Centralidade do } \\
\text { paciente }\end{array}$ & $\begin{array}{l}\text { Pontuação média no } \\
\text { total itens de Percepção } \\
\text { / satisfação em } \\
\text { pesquisas com } \\
\text { pacientes }\end{array}$ & $\begin{array}{l}\text { O indicador é calculado com base } \\
\text { no questionário utilizado atualmente } \\
\text { no hospital. (Não é para } \\
\text { comparações internacionais e } \\
\text { nacionais, mas para } \\
\text { acompanhamento dentro da } \\
\text { organização. Se pesquisas padrão } \\
\text { são usadas em um país, o } \\
\text { benchmarking nacional é proposto) }\end{array}$ & \\
\hline $\begin{array}{l}\text { 17. Aspectos } \\
\text { interpessoais }\end{array}$ & $\begin{array}{l}\text { Pontuação média em } \\
\text { itens de aspecto } \\
\text { interpessoal em } \\
\text { pesquisas com } \\
\text { pacientes }\end{array}$ & $\begin{array}{l}\text { O indicador é calculado com base } \\
\text { no questionário utilizado atualmente } \\
\text { no hospital. (Uma pontuação média } \\
\text { é computada para todos os itens } \\
\text { relacionados a aspectos } \\
\text { interpessoais. Não é para } \\
\text { comparações internacionais e } \\
\text { nacionais, mas para } \\
\text { acompanhamento dentro da } \\
\text { organização. Se pesquisas padrão } \\
\text { são usadas em um país, o } \\
\text { benchmarking nacional é proposto) }\end{array}$ & \\
\hline $\begin{array}{l}\text { 18. Orientação ao } \\
\text { cliente: acesso }\end{array}$ & $\begin{array}{l}\text { Cirurgia cancelada de } \\
\text { última hora }\end{array}$ & $\begin{array}{l}\text { Número total de pacientes que } \\
\text { tiveram sua cirurgia cancelada ou } \\
\text { adiada por mais de } 24 \text { hora s, durante } \\
\text { o período de estudo e que } \\
\text { preenchem os critérios de inclusão }\end{array}$ & $\begin{array}{l}\text { Número total de } \\
\text { pacientes admitidos } \\
\text { para cirurgia durante o } \\
\text { período de estudo e } \\
\text { que atendem aos } \\
\text { critérios de inclusão }\end{array}$ \\
\hline
\end{tabular}


Continuação

\begin{tabular}{|c|c|c|c|}
\hline $\begin{array}{c}\text { Dimensões } \\
\text { (subdimensões) }\end{array}$ & $\begin{array}{l}\text { Indicadores de } \\
\text { desempenho }\end{array}$ & Numerador & Denominador \\
\hline $\begin{array}{l}\text { 19. Orientação ao } \\
\text { cliente: informação e } \\
\text { capacitação }\end{array}$ & $\begin{array}{l}\text { Pontuação média em } \\
\text { itens de informação e } \\
\text { empoderamento em } \\
\text { pesquisas de pacientes }\end{array}$ & $\begin{array}{l}\text { O indicador é calculado com base } \\
\text { no questionário utilizado atualmente } \\
\text { no hospital. (Uma pontuação média } \\
\text { é computada para todos os itens } \\
\text { relacionados a informações e } \\
\text { empoderamento do paciente. Não é } \\
\text { para comparações internacionais e } \\
\text { nacionais, mas para } \\
\text { acompanhamento dentro da } \\
\text { organização. Se pesquisas padrão } \\
\text { são usadas em um país, o } \\
\text { benchmarking nacional é proposto) }\end{array}$ & \\
\hline $\begin{array}{l}\text { 20. Orientação ao } \\
\text { cliente: continuidade }\end{array}$ & $\begin{array}{l}\text { Pontuação média na } \\
\text { continuidade dos itens } \\
\text { assistenciais nas } \\
\text { pesquisas com } \\
\text { pacientes }\end{array}$ & $\begin{array}{l}\text { O indicador é calculado com base } \\
\text { no questionário utilizado atualmente } \\
\text { no hospital. (Uma pontuação média } \\
\text { é calculada para todos os itens } \\
\text { relacionados à continuidade do } \\
\text { atendimento. Não é para } \\
\text { comparações internacionais e } \\
\text { nacionais, mas para } \\
\text { acompanhamento dentro da } \\
\text { organização. Se pesquisas padrão } \\
\text { são usadas em um país, o } \\
\text { benchmarking nacional é proposto) }\end{array}$ & \\
\hline
\end{tabular}

Fonte: adaptado de Veillard et al. (2005: 493-95).

Em outra iniciativa relevante, Vallejo et al. (2006) destacam os diversos esforços para a adaptação dos conteúdos do modelo de excelência da entidade The European Foundation for Quality Management (EFQM), seus critérios e subcritérios, para a atenção à saúde e propuseram uma aproximação dos oito conceitos fundamentais de excelência da EFQM (EFQM, 1999) para o campo de cuidados de saúde por meio de um enquadramento teórico-conceitual do projeto PATH. Como resultado desta análise, os conceitos de excelência da EFQM são adaptados aos cuidados de saúde, por meio do conjunto de elementos compilados do PATH e agregação de novos elementos.

A estrutura adaptada da assistência de saúde da EFQM, tem uma hierarquia de três níveis sintetizados por Vallejo et al. (2006) e ilustrada na Figura 3. Nos resultados finais, Vallejo et al. (2006: 333-34) propuseram um quadro de dimensões operacionais procedentes da adaptação do modelo EFQM para o campo de cuidados de saúde alinhadas pelo um enquadramento teórico-conceitual (framework) do projeto PATH, que se desdobrou em uma lista de dimensões e de indicadores sintetizados por (MOITA, 2019c: 531-35). 
Figura 3 - Quadro teórico-conceitual (framework) EFQM adaptado aos cuidados de saúde, conforme as dimensões do modelo PATH

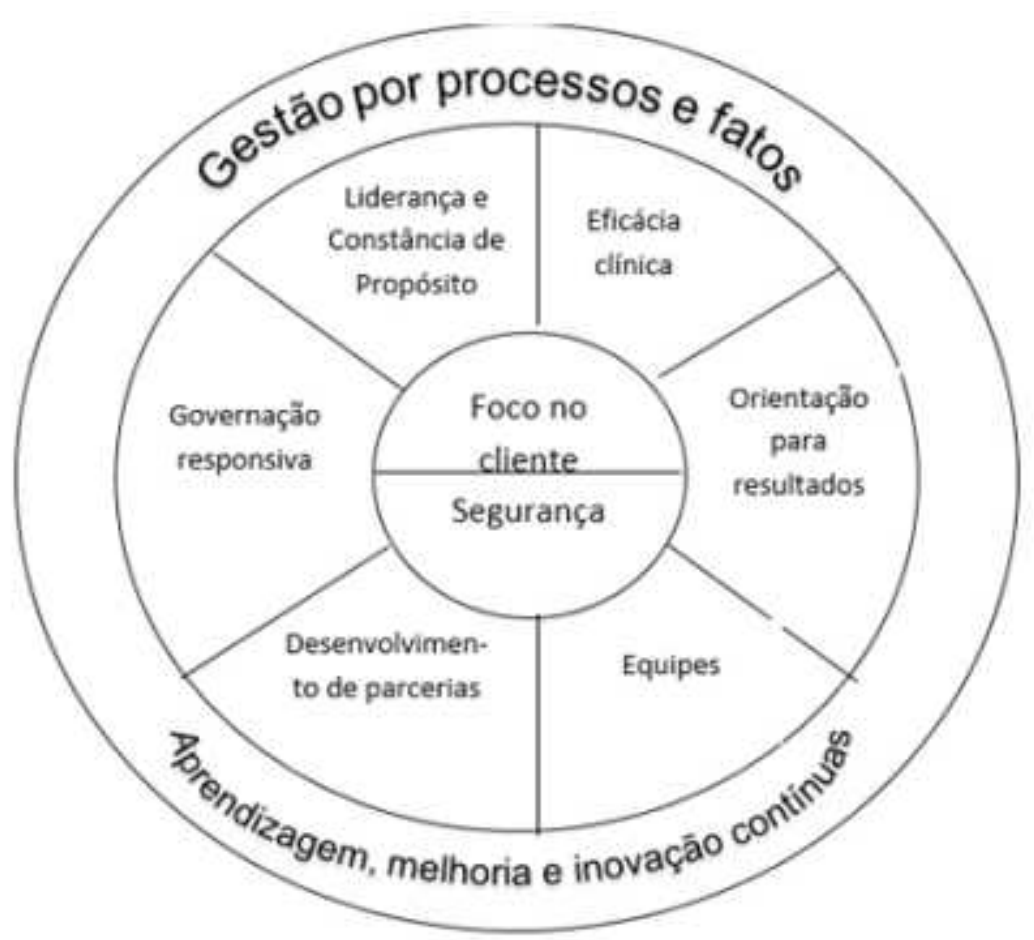

Fonte: adaptado de (VALLEJO; SAURA; SUNOL; KAZANDJIAN et al., 2006: 333-34)

Por sua vez, Papanicolas \& Smith (2010) comparam dez abordagens destacadas na literatura de quadro teórico-conceitual (framework) de sistemas de saúde e as classifica segundo estas três categorias, além de expor as limitações de cada um dos dez modelos estudados, sendo nove deles assinalados também como quadro teórico-conceitual (framework) de avaliação de desempenho de sistemas de saúde, exceto o modelo behavioural health care (Quadro 4). Citam que todos os modelos analisados têm similaridades, diferenças de escopo e de funcionalidades, mas assinalam (PAPANICOLAS; SMITH, 2010: 32) que a distinção mais óbvia entre estes modelos de quadro teóricoconceitual (framework) é a separação dos objetivos finais e intermediários, visto que os objetivos intermediários contribuem para a realização dos objetivos finais e, muitas vezes, fornecem informações valiosas sobre o desempenho do sistema de saúde. Por fim, Papanicolas \& Smith (2010: 33-35) sintetizaram objetivos finais e intermediários, similares às dimensões e subdimensões de performance sistematizadas por outros estudos.

Quadro 4 - Quadro de objetivos versus quadro teórico-conceitual (framework)

\begin{tabular}{|l|l|l|}
\hline \multicolumn{1}{|c|}{ Framework(nome) } & \multicolumn{1}{|c|}{ Objetivo Intermediário } & \multicolumn{1}{c|}{ Objetivo Final } \\
\hline $\begin{array}{l}\text { Framework for Assessing } \\
\text { Behavioural Healthcare(1998) }\end{array}$ & $\begin{array}{l}\text { - Eficácia } \\
\text { - Eficiência } \\
\text { - Equidade }\end{array}$ & - Saúde ebem-estar \\
\hline EGIPSS model (1998) & $\begin{array}{l}\text { - Produtividade } \\
\text { - Volume decuidados e serviços } \\
\text { - Qualidade de cuidados e } \\
\text { serviços }\end{array}$ & $\begin{array}{l}\text { - Melhoria da saúde } \\
\text { - Eficácieincia } \\
\text { - Equidade }\end{array}$ \\
\hline
\end{tabular}


Continuação

\begin{tabular}{|c|c|c|}
\hline Framework(nome) & Objetivo Intermediário & Objetivo Final \\
\hline $\begin{array}{l}\text { WHO Performance Framework } \\
(2000)\end{array}$ & $\begin{array}{l}\text { - Acesso } \\
\text { - Cobertura } \\
\text { - Qualidade } \\
\text { - Segurança }\end{array}$ & $\begin{array}{l}\text { - Nível e distribuição de saúde } \\
\text { - Nível e distribuição decapacidade de } \\
\text { resposta } \\
\text { - Justiça no financiamento } \\
\text { - Eficiência }\end{array}$ \\
\hline $\begin{array}{l}\text { OECD Performance Framework } \\
(2001)\end{array}$ & & $\begin{array}{l}\text { - Nível e distribuição de saúde } \\
\text { - Nível e distribuição de capacidade de } \\
\text { resposta e acesso } \\
\text { - Equidade } \\
\text { - Eficiência macroeconômica e } \\
\text { microeconômica }\end{array}$ \\
\hline $\begin{array}{l}\text { Control Knobs Framework } \\
(2003)\end{array}$ & $\begin{array}{l}\text { - Eficiência } \\
\text { - Qualidade } \\
\text { - Acesso }\end{array}$ & $\begin{array}{l}\text { - Estado de saúde } \\
\text { - Satisfação do usuário } \\
\text { - Proteção contra riscos }\end{array}$ \\
\hline $\begin{array}{l}\text { Commonwealth Fund } \\
\text { Framework(2006) }\end{array}$ & $\begin{array}{l}\text { - Alta qualidade do cuidado } \\
\text { - Cuidado eficiente } \\
\text { - Acesso } \\
\text { - Inovação e melhoria do } \\
\text { sistema e da força de trabalho }\end{array}$ & - Vidas longas, saudáveis e produtivas \\
\hline $\begin{array}{l}\text { OECD HCQI Framework } \\
(2006)\end{array}$ & & $\begin{array}{l}\text { - Melhoria da saúde } \\
\text { - Eficiência macroecôomica } \\
\text { (sustentabilidade) e eficiência } \\
\text { microeconômica (valor para o dinheiro) } \\
\text { - Equidade }\end{array}$ \\
\hline $\begin{array}{l}\text { WHO Building Blocks } \\
\text { Framework }(2007)\end{array}$ & $\begin{array}{l}\text { - Acesso } \\
\text { - Cobertura } \\
\text { - Qualidade } \\
\text { - Segurança }\end{array}$ & $\begin{array}{l}\text { - Nível e distribuição de saúde } \\
\text { - Nível e distribuição de capacidade de } \\
\text { resposta } \\
\text { - Justiça no financiamento } \\
\text { - Eficiência }\end{array}$ \\
\hline Systems Framework (2008) & $\begin{array}{l}\text { - Equidade } \\
\text { - Escolha } \\
\text { - Eficiência } \\
\text { - Eficácia }\end{array}$ & $\begin{array}{l}\text { - Saúde } \\
\text { - Proteção contra risco financeiro } \\
\text { - Satisfação do usuário }\end{array}$ \\
\hline $\begin{array}{l}\text { IHP Common Evaluation } \\
\text { Framework (2008) }\end{array}$ & N/A & N/A \\
\hline
\end{tabular}

Fonte: adaptado de Papanicolas e Smith (2010: 33-35)

Assim, esses diferentes marcos teóricos-conceituais explanados acima, conformaram um framework potencial e nortearam os pesquisadores quanto a validação de dimensões e indicadores de avaliação de desempenho e resultados relevantes para a saúde brasileira, conforme a avaliação da importância atribuída por gestores e decisores de saúde, mas, na etapa inicial, buscou-se mapear os conhecimentos prévios dos respondentes, sem fazer vínculos com a literatura, que foram diretrizes para aprofundamentos em etapas posteriores.

A inclusão dos diversos atores na decisão da modelagem da avaliação se faz necessária também pela variedade de dimensões mensuráveis nos serviços de saúde, e pela necessidade de priorização por 
seus futuros utilizadores (MOITA, 2019c; MOITA; RAPOSO; BARBOSA, 2019c; MOITA; RAPOSO; BARBOSA, 2020). Neste quesito, Uchimura e Bosi (UCHIMURA; BOSI, 2002) referem-se a autores e listas das possíveis dimensões de avaliação. Gattinara e outros (GATTINARA; IBACACHE; PUENTE; GIACONI et al., 1995) sinalizam vários fatores que determinam a qualidade dos serviços de saúde: competência profissional, satisfação dos usuários-utilizadores, acessibilidade, eficácia, eficiência. Por outro lado, Vuori (VUORI, 1991) aponta efetividade, eficácia, eficiência, outros, também com modelos referidos por Acurcio (ACURCIO; CHERCHIGLIA; SANTOS, 1991), por Akerman e Nadanovsky (AKERMAN; NADANOVSKY, 1992) e por Santos (SANTOS, 1995).

Em outro prisma, Hartz e Vieira-da-Silva (2005) abordam a avaliação enquanto desenhos de modelos teóricos-lógicos para a compreensão das relações de lógica entre os objetivos, atividades e resultados do programa. Assim, o objeto da investigação científica é um constructo da realidade passível de modelagem, instrumentalizado em dois momentos: a idealização do objeto-modelo ou modelo conceitual e a construção da teoria do objeto-modelo ou, em outros termos, a elaboração do modelo teórico (BUNGE, 1974). O modelo lógico (ML) é entendido enquanto um esquema visual que apresenta como um programa deve ser implementado e que resultados são esperados (ROWAN, 2000).

Estabeleceu-se um modelo lógico para orientar a proposta inicial de coleta de dados qualitativos para a estruturação da visão global, a partir do esquema proposto por Hartz e Vieira-da-Silva (2005) e de macrodimensões de avaliação de desempenho prevalentes na análise da literatura genérica pelos autores (SOUZA; VIEIRA-DA-SILVA; HARTZ, 2005). Utilizou-se o modelo genérico da Figura 4 para subsidiar a avaliação e evitar direcionamentos das análises dos respondentes, nessa captação de conhecimentos iniciais de especialistas, gestores, profissionais.

Figura 4 - Diagrama do modelo lógico - atributos ou características para avaliação em saúde

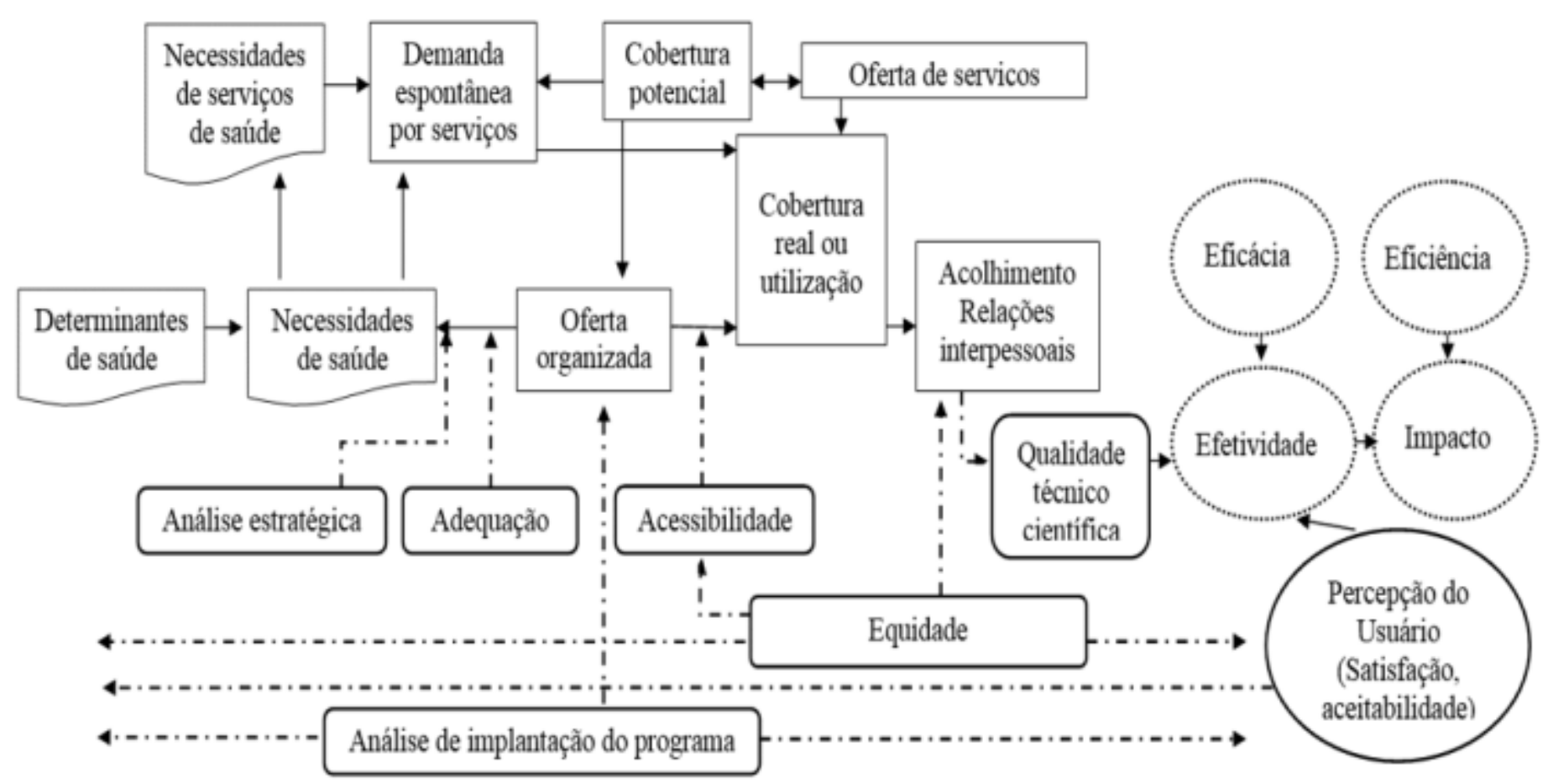

Fonte: Elaborado a partir do esquema proposto por Hartz e Vieira-da-Silva (2005). 
Em seguida, os resultados obtidos nas respostas das fases 1 a 3 foram avaliados, categorizados e readequados conforme as macrodimensões de performance definidas pela literatura mais relevante (ACURCIO; CHERCHIGLIA; SANTOS, 1991; AKERMAN; NADANOVSKY, 1992; GATTINARA; IBACACHE; PUENTE; GIACONI et al., 1995; SANTOS, 1995; VIACAVA; ALMEIDA; CAETANO; FAUSTO et al., 2004; VIEIRA-DA-SILVA, 2005; VUORI, 1991), subsidiando o ajuste e a consolidação de um novo questionário semiestruturado (fase 4).

Em termos de variáveis e indicadores (domínios e macrodomínios de avaliação) que emergiram dos conhecimentos prévios dos respondentes dessa investigação, pode-se sintetizar as seguintes categorias indicadas no Quadro 5 abaixo.

Quadro 5 - Síntese dos domínios e macrodomínios prevalentes na pesquisa inicial.

\begin{tabular}{|c|c|}
\hline Macrodomínios & Definições conceituais \\
\hline I. Quantitativos & $\begin{array}{l}\text { Seis domínios referentes a asqes de produtividade, estrutura assistenc } \\
\text { cobertura e de finanças/economia (D1A_Produtiprodutividade assistencia } \\
\text { D1B_EstrutAssist estrutura assistenciąl D1C_CobertAssit cobertura de } \\
\text { atendimentos D1D_OtimizCusto otimização de custosD1E_EficienEcon- } \\
\text { eficiência econômicae D1F_SustEconFin sustentabilidade econômica } \\
\text { financeirà. }\end{array}$ \\
\hline II. Qualitativos & 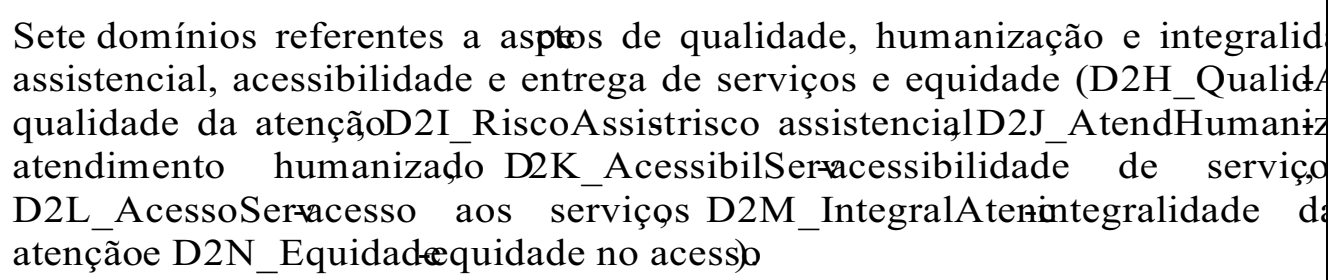 \\
\hline III. Efeitos & $\begin{array}{l}\text { Cinco domínios referentes a aspes de eficácia, efetividade, eficiên } \\
\text { resolutvidade e impacto (D3P_EficaciaProj eficácia projetada } \\
\text { D3Q_EfetivClinica efetividade clíniça D3R_EficienAssist eficiência da } \\
\text { assistência D3S_ResolubAssist resolutividade assistenciab D3T_Impacto } \\
\text { impacto na saúde populacional }\end{array}$ \\
\hline IV. Satisfação & $\begin{array}{l}\text { Dois domínios referentes a asqtos de qualidade satisfação (D4U_SatisfUsuari } \\
\text { satisfação do usuário D4V_SatisfProfisssatisfação do profission)al }\end{array}$ \\
\hline $\begin{array}{l}\text { V. Sistêmico/ } \\
\text { estratégico }\end{array}$ & $\begin{array}{l}\text { Cinco domínios referentes a aşos de gestãoestratégica do sistema de saú } \\
\text { (D5W_IndICSAP internações evitáveis por condições sensíveis a ,A } \\
\text { D5X_AtendVincReg atendimento de usuário vinculado a região de sá } \\
\text { D5Y_AtendDesVincRegatendimento de usuário vinculado a região de saú } \\
\text { D5V_ExtrapTtoOrç- extrapolação de teto orçamentátio }\end{array}$ \\
\hline
\end{tabular}

Fonte: Elaboração própria a partir de (MOITA; RAPOSO; BARBOSA, 2019c; MOITA; RAPOSO; BARBOSA, 2020)

Desta análise descritiva, sintetizou-se que os especialistas e profissionais atribuíram elevados (superior ou cerca de 4) graus de importância/relevância das subcategorias (20 e 24 domínios de avaliação) e das categorias (cinco e seis macrodomínios de avaliação) dos itens de análise, sendo considerados relevantes/importantes para a estruturação de um instrumento de avaliação de performance, conforme sintetizado na Figura 5 abaixo. 
Figura 5 - Grau de importância/relevância de domínios e macrodomínios de avaliação (visão de especialistas, profissionais e gestores de saúde)

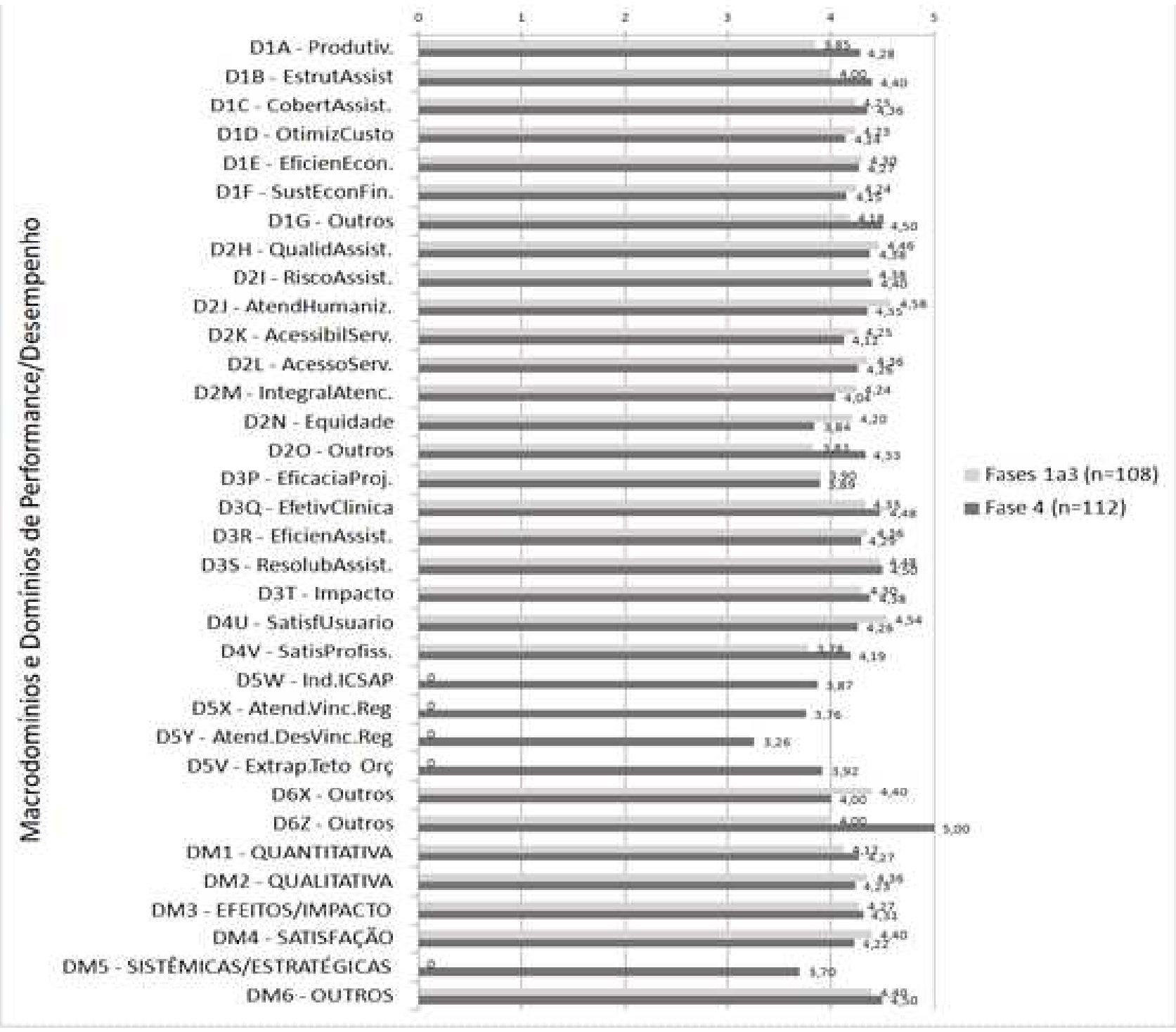

Fonte: Elaboração própria a partir de (MOITA; RAPOSO; BARBOSA, 2019c; MOITA; RAPOSO; BARBOSA, 2020)

\section{CONSIDERAÇÕES FINAIS}

Os resultados obtidos das respostas de 108 especialistas e profissionais de gestão e de 112 gestores de saúde, em quatro fases sucessivas (painel de especialistas, grupos Delphi e pesquisa de campo), foram objetos de análise descritiva e de significância estatística, que demonstrou que os informantes atribuíram elevados (superior ou cerca de 4) graus de importância/relevância das subcategorias (20 e 24 domínios de avaliação) e das categorias (cinco e seis macrodomínios de avaliação) dos itens de análise, sendo considerados relevantes/importantes para a aplicação da análise inferencial. Além disso, em média, as valorações da ampla maioria desses itens de análise foram razoavelmente dentro das mesmas margens de valores, uma vez que a maioria dos intervalos de confiança se sobrepuseram. As 3 possíveis variáveis mediadoras analisadas (níveis de atenção à saúde, de complexidade da assistência e de cargo/função dos gestores) não se consolidaram como fatores mediadores relevantes da maioria dos macrodomínios e da performance global (PGP). 
Por sua vez, a confiabilidade e a validade confirmadas dos 5 macrodomínios validados (Quantitativos, Qualitativos, Efeitos, Satisfação e Sistêmico/Estratégico), além dos 17 domínios que permaneceram na análise do modelo final, guardam similaridades com as propostas do Proadess e IDSUS (VIACAVA; ALMEIDA; CAETANO; FAUSTO et al., 2004; VIACAVA; UGÁ; PORTO; LAGUARDIA et al., 2012). Esses achados podem abrir novas perspectivas para a gestão dos serviços de saúde no sentido de obter informações cientificamente válidas acerca da percepção dos decisores, possivelmente, evitando as dificuldades e desalinhamentos de métodos de aferição sem validação por especialistas e contribuindo para a mensuração da performance em serviços de saúde por um método de seleção de itens de avaliação a partir das valorações de especialistas, profissionais e gestores. Garantiram-se a confiabilidade e a validade de 17 domínios (indicadores) e de 4 macrodomínios (dimensões) de performance, além de modelar os impactos de seus reflexos sobre a PGP no modelo final (MOITA; RAPOSO; BARBOSA, 2019c; MOITA; RAPOSO; BARBOSA, 2020).

Os resultados consolidados abrem novas perspectivas para a gestão dos serviços de saúde, no sentido de se obter informações cientificamente válidas acerca da percepção dos especialistas e gestores da saúde, possivelmente evitando as dificuldades e desalinhamentos de métodos de aferição sem validação por especialistas e contribuindo para a legitimidade e usabilidade dos instrumentos analíticos para comparação entre diferentes unidades avaliadas, enquanto itens de orientação para intervenção de gestores nas unidades de saúde do SUS. 


\section{REFERÊNCIAS}

ACURCIO, F. A.; CHERCHIGLIA, M. L.; SANTOS, M. A. Avaliação de qualidade de serviços de saúde. Saúde em debate. Rio de Janeiro. 33: 4 p. 1991.

AKERMAN, M.; NADANOVSKY, P. Evaluation of health services - What to Evaluate? Cad. Saúde Pública, oct/dez, 8, n. 4, p. 5, 1992.

ALKIN, M. C.; CHRISTIE, C. A. Evaluation Roots: Tracing Theorist's Views and Influences. Sage publications, 2004.

ALMEIDA, C. M. Reforma do Estado e reforma de sistemas de saúde: experiências internacionais de tendências de mudança. Ciênc. \& Saúde Coletiva, 4, n. 2, p. 24, 1999.

ALVES, A. S. D. Responsabilidade e Governação na Moderna Gestão Hospitalar. 2012. Doctoral -, Universidade de Aveiro, Portugal: Aveiro.

ARAH, O. A.; CUSTERS, T.; KLAZINGA, N. S. Updating the key dimensions of hospital performance: the move towards a theoretical framework. In: 3rd Workshop on Hospital Performance Measurement, 2003, Barcelona. WHO Regional Office for Europe, Disponível e m: https://www.researchgate.net/publication/254902535_Updating_the_key_dimensions_of_hospital_performa nce_the_move_towards_a_theoretical_framework.

ARAH, O. A.; KLAZINGA, N. S.; DELNOIJ, D. M. J.; ASBROEK, A. H. A. T. et al. Conceptual frameworks for health systems performance: a quest for effectiveness, quality, and improvement. International Journal for Quality in Health Care, 15, n. 5, p. 22, 2003.

ARAH, O. A.; WESTERT, G. P.; HURST, J.; NIEK, S. et al. A conceptual framework for the OECD health care quality indicators project. International Journal for Quality in Health Care, p. 9, 2006.

BOCCOLINI, C. S.; BOCCOLINI, P. M. M.; DAMACENA, G. N.; FERREIRA, A. P. S. et al. Fatores associados à discriminação percebida nos serviços de saúde do Brasil: resultados da Pesquisa Nacional de Saúde, 2013 Ciênc. \& Saúde Coletiva, 21, n. 2, p. 8, 2016.

BOSI, M. L.; MERCADO, F. J. Pesquisa qualitativa de serviços de saúde. 2006.

BRASIL. Alternativas de gerência de unidades públicas de saúde. Para entender a gestão do SUS 2015. Brasília Ministério da Saúde: 157 p. 2015.

BROOK, R. H.; LOHR, K. Efficacy, effectiveness, variations and quality: boundary-crossing research. Med Care, 23, n. 5, p. 23, 1985.

BRYSON, J. What to do when stakeholders matter: Stakeholder identification and analysis techniques. Public Management Review, 6, n. 1, p. 33, 2004.

BUNGE, M. Os conceitos do modelo: modelo na ciência teórica. In: Teoria e realidade. Perspectiva ed. São Paulo: Perspectiva, 1974. p. 11-40.

CAMPOS, R. T. O.; FURTADO, J. P. Desafios da avaliação de programas e serviços em saúde: novas tendências e questões emergentes. Editora Unicamp ed. Campinas, São Paulo: Editora Unicamp, 2011.

CARVALHO, C. Organizações, actores envolvidos e partes interessadas: determinantes da saliência dos stakeholders e sua relação com o desempenho organizacional. 2007. Doutorado -, Universidade de Coimbra, Coimbra, Portugal. 
CHIANCA, T.; YOUKER, B. La evaluación em América Latina y EI Caribe. Visión general de los desarrollos recientes. 2004. CONTANDRIOPOULOS, A. P. Avaliando a institucionalização da avaliação. Ciênc. Saúde Coletiva, 10, n. 3, p. 7, 2006.

DONABEDIAN, A. Basic approaches to assessment: structure, process and outcome. In: PRESS, H. A. (Ed.). Explorations in quality assessment and monitoring. Michigan: Health Administration Press, 1980. v. 1, p. 77-125.

DOS REIS, E. J. F. B.; DOS SANTOS, F. P.; DE CAMPOS, F. E.; ACURCIO, F. A. et al. Avaliação da qualidade dos serviços de saúde: notas bibliográficas. Cad. Saúde Pública, Trimestral, 6, n. 1, p. 12, 1990.

DÉNIZ-DÉNIZ, M.; ZÁRRAGA-OBERTY, C. The assessment of the stakeholders' environment in the new age of knowledge: an empirical study of the influence of the organisational structure. Business Ethics: A European Review, 13, n. 4, p. 17, 2004.

EFQM, E. F. F. Q. M.-. Healthcare working group, Strategic directions. Brussels: EFQM Representative Office 1999.

FALS BORDA, O.; MORA-OSEJO, L. E. La superación del Eurocentrismo. Enriquecimiento del saber sistémico y endógeno sobre nuestro contexto tropical. Polis, Revista de la Universidad Bolivariana. Polis, Revista de la Universidad Bolivariana. 22004.

FERNANDES, F. M. B.; RIBEIRO, J. M.; MOREIRA, M. R. Reflexões sobre avaliação de políticas de saúde no Brasil. Cad. Saúde Pública. Rio de Janeiro: Cad. Saúde Pública. 27: 11 p. 2011.

FLEXNER, A. Medical Education in United States and Canada: Report to Carnegie Foundation for Advencement of Teaching. New York: Merrymount Press 1910.

FREEMAN, R. Strategic management: A stakeholder approach. Boston: Pitman, 1984.

GATTINARA, B. C.; IBACACHE, J.; PUENTE, C.; GIACONI, J. et al. Percepcion de la comunidad acerca de la calidad de los servicios de salud públicos en los distritos Norte e Ichilo, Bolívia. Caderno de Saúde Publica. 11: 14 p. 1995.

HART, S.; SHARMA, S. Engaging fringe stakeholders for competitive imagination. Academy of Management Executive. Academy of Management Executive. 18: 12 p. 2004.

HARTZ ,Z. M. A.; VIEIRA-DA-SILVA, L. M. Avaliação em saúde. EDUFBA. Salvador: 25 p. 2005.

HURST, J. Challenges for health systems in Member Countries of the Organisation for Economic Co-operation and Development. Bull World Health Organ, 78, p. 10, 2000.

LOBATO, L. D. V. C.; RIBEIRO, J. M.; VAITSMAN, J. Public/Private Mix in the Brazilian Health System and the Quest for Equity. Global Social Welfare, 3, p. 9, 2016.

MACHADO, J. P.; MARTINS, A. C. M.; MARTINS, M. S. Avaliação da qualidade do cuidado hospitalar no Brasil: uma revisão sistemática. Cad. Saúde Pública. Rio de Janeiro: Cad. Saúde Pública. 29: 20 p. 2013.

MALTA, D. C.; SANTOS, M. A. S.; STOPA, S. R.; VIEIRA, J. E. B. et al. A cobertura da estratégia de saúde da família (ESF) no Brasil, segundo a pesquisa nacional de saúde, 2013. Ciência \& Saúde Coletiva, 21, n. 2, p. 12, 2016.

MELLAHI, K.; WOOD, J. The role and potential of stakeholders in "holoow participation": conventional stakeholder theory and institutionalism alternatives. Business and Society Review, 108, n. 2, p. 20, 2003.

MOITA, G. F. Avaliação e monitoramento de resultados no planejamento regional do SUS: pactuações, desafios e potencialidades. Orientador: RIBEIRO, J. M. 2019a. 184 f. Master (Mestrado) - Escola Nacional de Saúde Pública Sérgio Arouca, Fundação Oswaldo Cruz (Fiocruz), Rio de Janeiro. Disponível em: https://www.arca.fiocruz.br/simple-search?query=Galba+Freire+Moita.

MOITA, G. F. Avaliação integrativa de performance multidimensional e decisão multicritério: um proxy de painel de indicadores de eficiência, efetividade e qualidade para governança de organizações hospitalares e serviços de saúde no Brasil. Orientador: RAPOSO, V. M. e BARBOSA, A. C. Q. 2019b. 364 f. Doctoral (Doutoramento) - 
Faculdade de Ciências Econômicas - Departamento de Ciências Administrativas, Universidade Federal de Minas Gerais, Belo Horizonte. Disponível em: http://hdl.handle.net/1843/32451.

MOITA, G. F. Avaliação integrativa de performance multidimensional e decisão multicritério: um proxy de painel de indicadores de eficiência, efetividade e qualidade para governação de organizações hospitalares e serviços de saúde no Brasil. Orientador: RAPOSO, V. M. e BARBOSA, A. C. Q. 2019c. 366 f. Doctoral (Doutoramento) Faculdade de Economia, Universidade de Coimbra, Coimbra. Disponível em: http://hdl.handle.net/10316/88714.

MOITA, G. F.; RAPOSO, V. M. R.; BARBOSA, A. C. Q., 2018, Madrid. Validación colaborativa de instrumentos de apoyo a la toma de decisión y medición de satisfacción de usuarios de salud pública en Brasil. Actas Gobernando el Futuro: gestión y políticas públicas para el desarrollo sostenible. Disponível em: http://https://congreso2018.gigapp.org/es/program-schedule/program/1/gt-especial-gob01-gobernanza-einnovaciones-participativas-en-america-latina-gipal-contextos-disenos-institucionales-y-factores-de-exito.

MOITA, G. F.; RAPOSO, V. M. R.; BARBOSA, A. C. Q. Collaborative validation of decision-making supporting tools in public health users in Brazil. GIGAPP Estudios Working Papers, 6, n. 132, p. 21, 2019a.

MOITA, G. F.; RAPOSO, V. M. R.; BARBOSA, A. C. Q., 2019b, Madrid. The frontier of the evaluation of results of the Unified Health System: Reliability and validity of the evaluation items for the measurement of health performance in Brazil. Actas Gobernando el Futuro: agenda 2030. 28.

MOITA, G. F.; RAPOSO, V. M. R.; BARBOSA, A. C. Q. Validação colaborativa de macrodimensões e indicadores-chave para avaliação de performance de serviços de saúde no Brasil. Rev. Saúde em Debate, 43, n. 5, p. 232-247, 2019c.

MOITA, G. F.; RAPOSO, V. M. R.; BARBOSA, A. C. Q. A construção de um modelo de avaliação por profissionais e gestores de saúde: validação e consolidação de dimensões e indicadores de performance em serviços e unidades de saúde do SUS. Rev. Serv. Público, jul/set, 70, n. 3, p. 41, 2020.

MORRA IMAS, L. G.; RIST, R. C. The Road to Results Designing and Conducting Effective Development Evaluations. Washington: The Wolrd Bank, 2009. 611 p. Disponível em: https://openknowledge. worldbank.org/handle/10986/2699.

NICO, L. S.; ANDRADE, S. S. C. A.; MALTA, D. C.; JÚNIOR, G. A. P. et al. Saúde bucal autorreferida da população adulta brasileira: resultados da pesquisa nacional de saúde 2013. Ciência \& Saúde Coletiva, 21, n. 2, p. 10, 2016.

OECD. Performance measurement and performance management in OECD health systems. p. 1-60. 2001. (47).

OECD. Health at a Glance 2017: OECD Indicators. Paris. 2017.

PAPANICOLAS, I.; SMITH, P. C. EuroREACH Framework for Health System Performance. 2010.

PATTON, M. Q. Utilization-Focused Evaluation: The New Century Text. London: Sage Publications, 1997.

PEREZ ARIAS, E. B.; FELLER, J. J. El control de los sistemas de atencion médica conceptualizacion y mecánica operativa. Medicina y Sociedade. Buenos Aires. 6:8 p. 1983.

PIOLA, S. F.; DE FRANÇA, J. R. M.; NUNES, A. Os efeitos da Emenda Constitucional 29 na alocação regional dos gastos públicos no Sistema Único de Saúde no Brasil Ciência \& Saúde Coletiva. Ciência \& Saúde Coletiva. 21: 12 p. 2016.

PORTERFIELD, J. D. Evaluation of Patients: Codman Revisited. Acad. Med. Bull. N. Y: Acad. Med. 52: 9 p. 1976.

RAPOSO, V. Governação hospitalar - uma proposta conceptual e metodológica para o caso português. 2007. Faculdade de Economia, Universidade de Coimbra, Coimbra.

ROSALEM, V. Análise das percepções dos principais atores da cadeia produtiva da saúde sobre a qualidade dos serviços prestados por hospitais no Estado de Goiás - Brasil. 2013. Doctoral -, Escola de Administração de Empresas de São Paulo, São Paulo. 
ROWAN, M. S. Logic models in primary care reform. navigating the evaluation. Canadian Journal of Program Evaluation, 15, n. 2, p. 12, 2000.

SAMICO, I.; FELISBERTO, E.; FIGUEIRÓ, A. C.; FRIAS, P. G. Avaliação em saúde: bases conceituais e operacionais. Rio de Janeiro: Medbook, 2010.

SANTOS, M. P. Avaliação da qualidade dos serviços públicos de atenção à saúde da criança sob a ótica do usuário. Revista Brasileira de Enfermagem. 48: 11 p. 1995.

SOUZA, L. E. P. F.; VIEIRA-DA-SILVA, L. M.; HARTZ, Z. M. A. Avaliação em Saúde: dos modelos teóricos à prática na avaliação de programas e sistemas de saúde. In: Conferência de consenso sobre a imagem-objetivo da descentralização da atenção à saúde no Brasil, 2005, Rio de Janeiro. Editora Fiocruz.

SOUZA-JÚNIOR, P. R. B. D.; FREITAS, M. P. S. D.; ANTONACI, G. D. A.; SZWARCWALD, C. L. Desenho da amostra da Pesquisa Nacional de Saúde 2013. Epidemiologia e Serviços de Saúde, 24, n. 2, p. 207-216, 2015.

SZWARCWALD, C. L.; MALTA, D. C.; PEREIRA, C. A.; VIEIRA, M. L. F. P. et al. Pesquisa Nacional de Saúde no Brasil: concepção e metodologia de aplicação Ciên. \& Saúde Coletiva, 19, n. 2, p. 10, 2014.

TANAKA, O. Y.; TAMAKI, E. M. O papel da avaliação para a tomada de decisão na gestão de serviços de saúde. Ciênc. Saúde Coletiva, 17, n. 4, p. 8, 2012.

TRAVASSOS, C.; NORONHA, J. C.; MARTINS, M. Mortalidade hospitalar como indicador de qualidade: uma revisão. Ciênc. Saúde Coletiva, 4, n. 2, p. 15, 1999.

UCHIMURA, K. Y.; BOSI, M. L. M. Qualidade e subjetividade na avaliação de programas e serviços em saúde Cad. Saúde Pública. Rio de Janeiro: Cad. Saúde Pública. 18: 9 p. 2002.

UNDP. Handbook on Planning, Monitoring and Evaluation for Development Results. 2009.

VALLEJO, P.; SAURA, R. M.; SUNOL, R.; KAZANDJIAN, V. et al. A proposed adaptation of the EFQM fundamental concepts of excellence to health care based on the PATH framework. International Journal for Quality in Health Care, 18, n. 5, p. 9, 2006.

VEILLARD, J. Performance Management in Health Systems and Services Studies on its Development and Use at International, National/Jurisdictional, and Hospital Levels. Orientador: BOOM, D. D. C. V. D. 2012. 194 f. Doctoral , Universiteit van Amsterdam, Amsterdam.

VEILLARD, J.; CHAMPAGNE, F.; KLAZINGA, N.; KAZANDJIAN, V. et al. A performance assessment framework for hospitals: the WHO regional office for Europe PATH Project. International Journal for Quality in Health Care, 17, n. 6, p. 9, 2005.

VIACAVA, F.; ALMEIDA, C.; CAETANO, R.; FAUSTO, M. et al. Uma metodologia de avaliação do desempenho do sistema de saúde brasileiro. Ciênc Saúde Coletiva, 9, n. 3, p. 14, 2004.

VIACAVA, F.; BELLIDO, J. G. Condições de saúde, acesso a serviços e fontes de pagamento, segundo inquéritos domiciliares Ciênc Saúde Coletiva, 21, n. 2, p. 20, 2016.

VIACAVA, F.; UGÁ, M. A. D.; PORTO, S.; LAGUARDIA, J. et al. Avaliação de Desempenho de Sistemas de Saúde: um modelo de análise Ciência \& Saúde Coletiva. 17:23 p. 2012.

VIEIRA-DA-SILVA, L. M. Conceitos, abordagens e estratégias para a avaliação em saúde. In: Avaliação em saúde. Salvador: EDUFBA, 2005. p. 15-39.

VUORI, H. A qualidade da saúde. Divulgação em saúde para debate. Caderno de Ciência e Tecnologia. 1: 9 p. 1991.

WORTHEN, B. R.; SANDERS, J. R.; FITZPATRICK, J. L. Avaliação de programas: Concepção e práticas. São Paulo: Edusp, Gente, 2004. 


\title{
MODELOS E INSTRUMENTOS DE AVALIAÇÃO DE QUALIDADE E SATISFAÇÃO NA EXPERIÊNCIA DE USUÁRIOS DE SAÚDE NO BRASIL
}

\author{
Galba Freire Moita \\ Univ. Coimbra, CeBER - Centre for Business and Economics \\ Research, Faculty of Economics \\ Zulmira Maria de Araújo Hartz \\ Universidade Nova de Lisboa - UNL \\ Global Health and Tropical Medicine - GHTM
}

\section{RESUMO}

A criação do Sistema Único de Saúde (SUS) no Brasil em 1988 representou avanços do ponto de vista das garantias de cuidado, organização sistêmica e descentralização da gestão unificada; no entanto, com um governo de desempenho frágil. A Nova Gestão Pública (NGP), ou Gerencialismo, tem exigido dos gestores públicos esforços de monitoramento de resultados, controladoria e accountability, além de garantias de entregas, efetividade e adequação às expectativas dos usuários e demais interessados. Pesquisas de opinião com base nacional mostraram insatisfação da população variando de 54 a $93 \%$. E, ainda, que muitos avaliam a saúde pública como ruim ou péssima, que aumentou de 61\% em 2011 para 75\% em 2018 . Em pesquisas bibliográficas se comprovou serem incipientes a avaliação de qualidade e satisfação no SUS. A iniciativa do Gespública propõs o índice IPPS, tendo muita similaridade com as cinco dimensões e as 22 questões da escala original SERVQUAL, entretando, não há evidências da validação da escala de satisfação que compõe o IPPS. Não há registros de continuidade do IPPS. Essa pesquisa objetivou lançar as bases teóricos-conceitauis para a tradução e validação da escala SERVQUAL no âmbito do SUS, por meio de análises de confiabilidade e validade , com resultados iniciais já publicados nos quais consolidou-se as bases da inovadora escala QUALITY SAÚDE sobre qualidade e satisfação de usuários do SUS.

\section{Palavras-chave:}

Qualidade, Acesso e Avaliação da Assistência à Saúde; Indicadores de Qualidade em Assistência à Saúde; Qualidade da Assistência à Saúde; Satisfação do Paciente;

Escalas de Valor Relativo

\begin{abstract}
The creation of the Unified Health System (SUS) in Brazil in 1988 represented advances in terms of care guarantees, systemic organization and decentralized unified management; however, with a weakperforming government. The New Public Management (NGP), or Managerialism, has demanded from public managers efforts to monitor results, controllership and accountability, in addition to guarantees of deliveries, effectiveness and adequacy to the expectations of users and other interested parties. Nationally-based opinion polls showed population dissatisfaction ranging from 54 to 93\% (CFM, 2014; 2015; 2018). And yet, that many evaluate public health as bad or very bad, which increased from 61\% in 2011 to $75 \%$ in 2018 (CNI, 2012; 2018). In bibliographic surveys (MOITA, 2019b; c) the assessment of quality and satisfaction in SUS was proven to be incipient. The Gespública initiative (BRASIL, 2014) proposed the IPPS index, which is very similar to the five dimensions and 22 questions of the original SERVQUAL scale, however, there is no evidence
\end{abstract}

of validation of the satisfaction scale that makes up the IPPS. There are no IPPS continuity records. This research aimed to lay the theoretical-conceptual bases for the translation and validation of the SERVQUAL scale (PARASURAMAN; BERRY; ZEITHAML, 1988a; 1991a) under SUS, through reliability and validity analyzes (MOITA, 2019b; c), with initial results already published (MOITA; BERNARDO; COSTA; AZEVEDO, 2018; MOITA, G. F; RAPOSO, VM R; BARBOSA, AC Q, 2019a; MOITA, GF; RAPOSO, VMR; BARBOSA, ACQ, 2019) in which it consolidated the foundations of the innovative QUALITY HEALTH scale on the quality and satisfaction of SUS users.

\section{Keywords:}

Quality, Access and Evaluation of Health Care; Health Care Quality Indicators; Quality of Health Care; Patient satisfaction; Relative Value Scales 


\section{INTRODUÇÃO}

A Nova Gestão Pública (NGP), ou o Novo Gerencialismo, tem exigido dos gestores públicos de saúde esforços de monitoramento de resultados, controladoria e responsabilização dos gastos (accountability) de políticas públicas (MOITA, G. F; RAPOSO, V. M. R; BARBOSA, A. C. Q, 2019b), além de garantias de entregas, efetividade e adequação às necesidades dos usuários. Alinhados com a visão da NGP ou Gerencialismo, pode-se citar exemplos de projetos de avaliação e monitoramento de resultados da administração pública como PRODEV 1 e P4R (PforR) ${ }^{2}$, que têm sido implantados na gestão pública de países em desenvolvimento, inclusive no Brasil, através de agências internacionais de fomento em busca de otimizar os recursos e garantir a qualidade às ações de órgãos públicos (MOITA, 2019a).

Por sua vez, desde a criação do Sistema Único de Saúde (SUS), muitos são os avanços do ponto de vista de garantias de atendimento, da organização sistêmica e da descentralização da gestão única, no entanto, pouco se observa avanços na governança do sistema de saúde. Nesse contexto, é crucial a implementação e desenvolvimento de um modelo de gestão das políticas de saúde baseada em agregação de valor, eficiência, efetividade e resolutividade, que pode ampliar em até cinco anos a expectativa de vida saudável, mantendo os gastos de saúde per capita correntes, comparadamente a contextos internacionais (OECD, 2018).

Em outro prisma, avaliar a qualidade dos serviços é um fator essencial para medir a satisfação dos usuários, retê-los e ter uma visão ampla da perspectiva dos consumidores de um serviço como forma de auxiliar no gerenciamento de recursos, da resolutividade dos serviços e da satisfação dos usuários de serviços públicos.

No contexto do Brasil, foram identificadas duas pesquisas de opinião de âmbito nacional do Conselho Federal de Medicina (CFM) e da Confederação Nacional da Indústria (CNI), com os institutos Datafolha e Ibope, que revelam a importância de avaliar qualidade e satisfação em saúde visto que apontam insatisfações da população entre 54 e 93\% (CFM, 2014; 2015; 2018). E, ainda, que há um alto percentual de brasileiros que avalia a saúde pública como ruim ou muito ruim, tendo aumentado de 61\% em 2011 para 75\% em 2018 (CNI, 2012; 2018), que variam de acordo com a perspectiva da análise e do direcionamento dessas pesquisas, principalmente no que se refere ao uso recente de serviços, seja em saúde pública ou suplementar.

Duas revisões sistemáticas no Brasil mostram que os primeiros estudos surgiram entre 1991 a 2003, tendo encontrado apenas 48 publicações (MACHADO; MARTINS; MARTINS, 2013) sobre avaliação de qualidade hospitalar e outro apenas 44 estudos (FERNANDES; RIBEIRO; MOREIRA, 2011) sobre a avaliação em saúde.

\footnotetext{
1 PRODEV - Programa de Estratégia e Plano de Ação para a Efetividade do Desenvolvimento do BID para os países da América Latina e Caribe

2 PforR ou P4R - Programa para Resultados do Banco Mundial para o apoio ao desenvolvimento da "accountability" de países em desenvolvimento
} 
Assim, algumas análises bibliográficas robustas nas principais bases de artigos científicos do Brasil (Medline; Lilacs; Scielo) (MOITA, 2019b; VOLPATO, 2014) mostraram que a avaliação de qualidade é um tema incipiente, além de que não identificaram nenhuma metodologia ou instrumento robustos para avaliar a qualidade e a satisfação de uso padronizado e validado e/ou amplamente aplicado à medição da satisfação na experiência dos usuários nos serviços públicos do Brasil.

Figura 1 - Bibliometria de estudos de avaliação em saúde no Brasil (1990 - 2018).

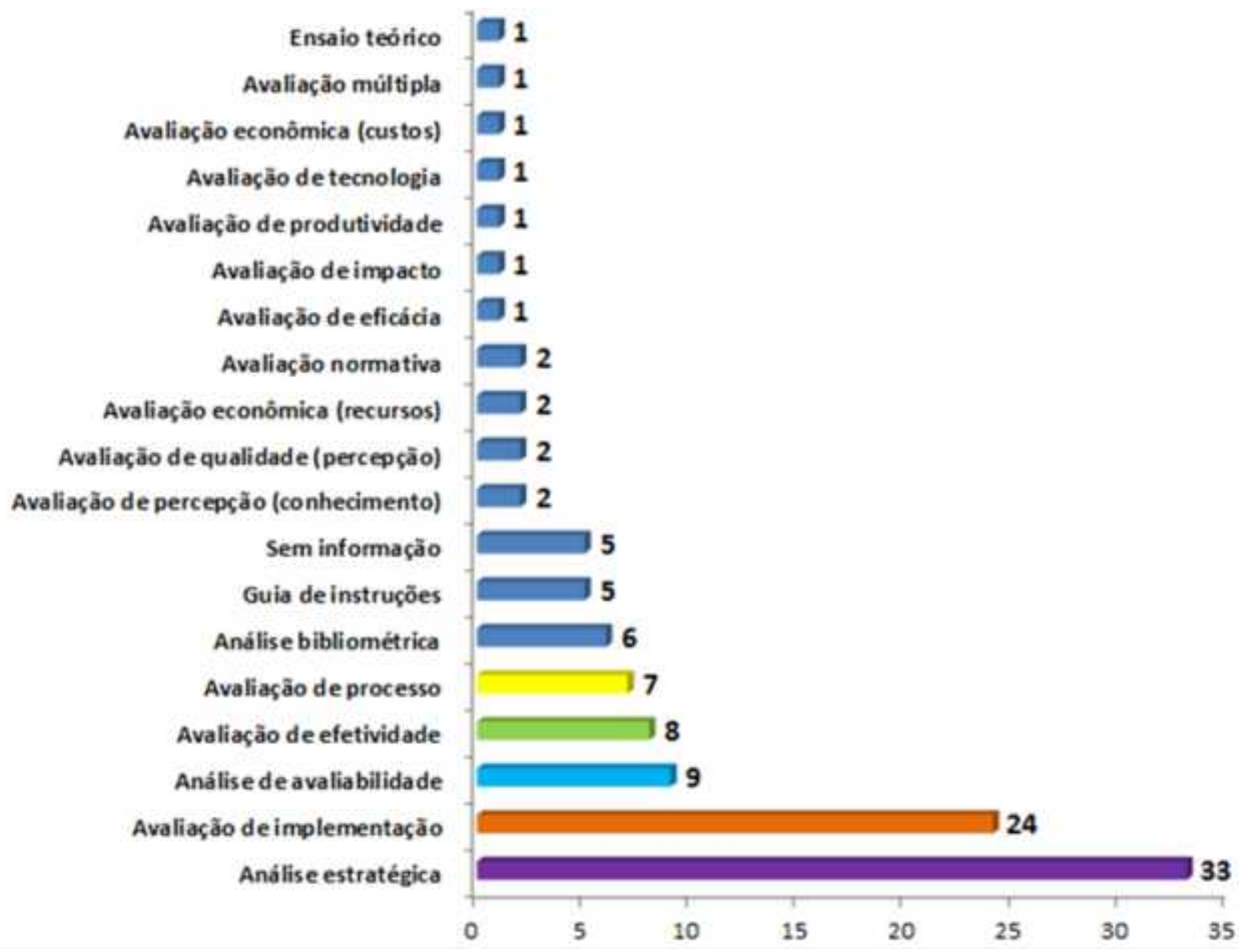

Fonte: elaboração própria.

Nesse contexto, desde 2002, o Ministério da Saúde (MS) tem operacionalizado duas estratégias de ouvidoria da opinião dos pacientes do SUS: a Carta SUS, um instrumento que consolida as informações dos atendimentos nas unidades hospitalares vinculadas ao SUS, que envia uma carta à residência do usuário para fornecer estas informações e solicitar retorno sobre sua percepção e satisfação quanto ao atendimento recebido; e o Disque Saúde - 196, que é uma linha telefônica gratuita pela qual qualquer cidadão pode encaminhar reclamações e sugestões sobre o sistema de saúde, inclusive quanto sua satisfação de atendimento no SUS. Porém, nestas duas iniciativas, pouco se avançou em modelos de avaliação de performance das unidades e/ou serviços do SUS.

Por sua vez, duas tentativas incipientes foram implantadas em 1998 e 2004, por uma parceria entre o MS e o Conselho Nacional de Secretários de Saúde (CONASS), não tendo se transformado em uma ferramenta de governação de organizações de saúde (BRASIL, 2003). Outras duas iniciativas foram a 
Pesquisa Mundial de Saúde (PMS) que foi aplicada em unidades de saúde de todo o Brasil, em 2003, além da PMS com foco específico na Atenção Básica, teve também a Pesquisa Mundial de Saúde com foco na Atenção Básica (PMS-AB) aplicada somente nos estados (províncias) do Rio de Janeiro e Pernambuco, em 2005. Ambas não tiveram continuidade e nem resultados sistematizados no SUS (GOUVEIA; SOUZA; LUNA; SOUZA-JÚNIOR et al., 2009).

Outro destaque é a iniciativa no bojo da iniciativa Gespública ${ }^{3}$ do Ministério do Planejamento do Brasil (BRASIL, 2009), pautado pelo Decreto no 5.378/2005 (BRASIL, 2005), criou-se a Carta de Serviço ao Cidadão além da proposição de um método de mensuração da satisfação de usuários de serviços públicos (BRASIL, 2010), no âmbito do Ministério do Planeamento do Brasil. No qual se propôs a criação do Instrumento Padrão de Pesquisa e Satisfação (IPPS) tendo analisado três metodologias internacionais (American Consumer Satisfaction Index da Universidade de Michigan; o SERVQUAL dos especialistas Zeithaml, Parasuraman e Berry- e também do Common Measurement Tool do Centro Canadense de Gestão). No IPPS, destacam-se as cinco dimensões proposta na escala SERVQUAL (confiabilidade, capacidade de resposta, segurança, empatia e tangibilidade) e as 22 questões originais do método que parecem ter sido objeto de traduções simplificadas e incorporadas diretamente na proposta de questionário vinculado ao IPPS, que segundo Batista e Paiva (2014) foi base para um software que combina elementos das principais metodologias internacionais de medição de satisfação dos usuários, na forma de um questionário de pesquisa de opinião padronizado.

Por sua vez, em 2011, o MS iniciou a estruturação de estratégias de monitoramento e avaliação do SUS, que se constitui por um conjunto de programas de avaliação relativamente independentes, mas relacionados, concatenados e complementares entre si. Entre os programas, pode-se citar: Índice de Desempenho do SUS (IDSUS), Programa Nacional de Avaliação de Serviços de Saúde (PNASS), Pesquisas Nacionais de Avaliação do Acesso e de Satisfação dos Usuários (carta SUS), Programa de Avaliação da Gestão do SUS e lançou o Programa de Avaliação para a Qualificação do Sistema Único de Saúde (SUS) (BRASIL, 2011; 2012a; b; c; 2015), instituindo o instrumento de Autoavaliação para a Melhoria do Acesso e da Qualidade da Atenção Básica (AMAQ) e o Programa Nacional de Melhoria do Acesso e da Qualidade da Atenção Básica (PMAQ) (BRASIL, 2012b).

Nesse escopo, o PMAQ, que teve três ciclos (2012, 2014 e 2015/2017), tem possibilitado um melhor entendimento da estrutura e forma de organização da ESF, sendo um banco de dados importante neste aspecto. Entretanto, as avaliações feitas, não permitem, por si só, a avaliação da ampliado para outras unidades de atenção primária de saúde, mas, no 3‥ ciclo do PMAQ (2015/2017), contou pela primeira vez com um quadro de indicadores de resultados das unidades (BRASIL, 2017a; d), mas de forma incipiente, especialmente quanto a qualidade e satisfação na experiência do usuário.

No prisma de transparência e participação dos cidadãos, o governo brasileiro reforçou a importância da participação no acompanhamento da prestação e na avaliação dos serviços pelos usuários através da Lei 13.460/2017 (BRASIL, 2017c) e do Decreto Federal 9.094/2017 (BRASIL, 2017b) e, que determinou a obrigatoriedade de avaliação periódica dos serviços pelas instituições públicas, além de estabelecer que os órgãos e entidades federais utilizem ferramenta de pesquisa de satisfação dos usuários e usem as informações coletadas para a melhoria dos serviços.

\footnotetext{
3 Programa Nacional de Gestão Pública e Desburocratização - GESPÚBLICA, instituído pelo decreto 5.378/2005 no âmbito do Ministério do Planejamento e descontinuado pelo Decreto 9.094/2017
} 
Neste escopo, registra-se o interesse de estudos de satisfação com os serviços públicos (DA SILVA, 2009) pelo que Da Silva e Schlegel (2012) analisaram um panorama de estudos seminais de satisfação com serviços públicos no Brasil, explorando alguns resultados de pesquisas de serviços públicos genéricos (para o conjunto dos serviços) em 1993 e 2006 e da avaliação de serviços específicos nos anos de 2002, 2006, 2008 e 2010, estudando três potenciais fatores moderadores das respostas: características socioeconômicas e demográficas; acesso às informações e conteúdos midiáticos; e o contato com serviços públicos.

Na análise dos dados das pesquisas de 2006, Da Silva e Schlegel (2012) afirmam que a regressão logística multinomial resultou com significância estatística os fatores: o nível de escolaridade, a atenção às notícias da mídia sobre políticas e o uso efetivo dos serviços que se associam negativamente à variável satisfação dos usuários de serviços públicos, possivelmente, por representar avaliações dos usuários com critérios mais críticos. Por sua vez, surgiu o fator moderador de moradia em capitais ou região metropolitana com efeito positivo em aumentar a satisfação, possivelmente, pelos serviços serem regiões com redes de assistência mais estruturadas. Destacam que "os índices positivos passaram a superar os negativos, tanto em avaliações genéricas (para o conjunto dos serviços) quanto em termos específicos (para setores determinados ou na esfera municipal)". Concluem que "o cidadão julga que os serviços deixam muito a desejar quando comparados a um "padrão ideal" ou se tomados como contrapartida de impostos tachados de "muito caros" por 3 em cada 4 brasileiros" (DA SILVA; SCHLEGEL, 2012).

A exigência normativa (BRASIL, 2017b; c) ainda não foi capaz de implementar instrumentos avaliativos de satisfação. Um inquérito recente da Escola Nacional de Administração Pública do (BRASIL, 2018) mapeou 1.740 os serviços de órgãos públicos da administração direta e revelou que mais de $75 \%$ dos serviços de órgãos e instituições federais não possuem avaliação regular de qualidade e/ou satisfação dos usuários, que enfatiza a importância de validação de uma metodologia para a medição da qualidade e satisfação percebida pelos usuários de serviços públicos.

Em 2013, o IBGE aplicou a Pesquisa Nacional de Saúde (PNS) (SOUZA-JÚNIOR; FREITAS; ANTONACI; SZWARCWALD, 2015; SZWARCWALD; MALTA; PEREIRA; VIEIRA et al., 2014), uma extensa amostra de domicílios de todo o Brasil com perspectiva de performance do sistema de saúde e alguns dados clínicos populacionais. A segunda edição na PNS foi aplicada em 2019, estando com resultados em análise e microdados em organização.

Esses contextos sugerem a relevância da avaliação da qualidade e satisfação pelos usuários de serviços públicos, além da promoção do empoderamento dos usuários, inclusive na validação incremental de questionários, aplicados na mensuração da qualidade percebida, em uma amostra selecionada da rede de unidades do SUS. Assim, visando adensar este campo de conhecimento, resolveu-se investigar um método de mensuração da qualidade e satisfação percebida pelo usuário do SUS, através da participação de profissionais e especialistas de qualidade e ouvidoria, além da captação de aspectos da experiência dos usuários doSUS.

Surge a importância dos modelos e escalas de qualidade, por exemplo, a SERVQUAL (BERRY; PARASURAMAN; ZEITHAML; ADSIT, 1994; PARASURAMAN; BERRY; ZEITHAML, 1988a; 1991a), mundialmente aplicada às diversas tipologias de serviços, tendo sido adaptado para serviços de saúde (BABAKUS, E.; MANGOLD, G., 1992; MANGOLD; BABAKUS, 1989) quanto a expectativa e a percepção na experiência de usuários e consumidores em algumas dimensões dos serviços. 
Registra-se uma multiplicidade de perspectivas de modelos avaliativos coexistentes do sistema de saúde mundial, além das diversidades de escopos, que geram complexidades inerentes aos diferentes modelos de avaliação da qualidade e satisfação, que por sua vez, agregam desafios crescentes para a avaliação da qualidade e satisfação de usuários em saúde.

Em busca de desenvolver um quadro teórico-conceitual de avaliação de qualidade e satisfação para organizações de saúde, aplicável às unidades do SUS, este estudo analisou algumas metodologias de mensuração de qualidade e satisfação de usuários em saúde no cenário mundial, além de uma pesquisa integrativa dos principais modelos aplicados no Brasil, especialmente quanto a potenciais escalas prevalentes na literatura.

Diante desse contexto, surge a problematização central desta investigação: em um ambiente de escassez de metodologias e instrumentos validados de mensuração de qualidade e satisfação em saúde, qual a importância relativa dos indicadores e dimensões de qualidade e satisfação dos usuários de saúde para a estruturação de quadros teóricos-conceituais (framework) e seus fatores mediadores de um proxy de escala de mensuração de qualidade e satisfação aplicados em saúde pública no Brasil?

No âmbito do SUS, justifica-se a importância deste estudo avaliativo, pois a avaliação é vista não só como instrumento para verificar a efetividade de programas, mas utilizada também com o intuito de melhorar a qualidade dos serviços por um processo de julgamento de valor orientado para a tomada de decisão e governança (RAPOSO, 2007).

Dessa forma, abordou-se o campo da avaliação de qualidade e satisfação em saúde, além de algumas perspectivas de metodologias e instrumentos com questões distribuídas em subescalas de análise (subdimensões e macrodimensões), para subsidiar a modelagem de uma plataforma virtual piloto e aplicação em caso exemplar multicêntrico.

\section{Avaliação de qualidade e satisfação na experiência de usuários}

Em busca de estabelecer um modelo avaliativo nota-se que não há na literatura um consenso sobre escopo e amplitude da avaliação e do monitoramento em saúde, mas muitos possíveis quadros teóricos conceituais (ARAH; CUSTERS; KLAZINGA, 2003; ARAH; KLAZINGA; DELNOIJ; ASBROEK et al., 2003; ARAH; WESTERT; HURST; NIEK et al., 2006; MURRAY; FRENK, 2000). Ante a multiplicidade de perspectiva, é basilar eleger uma base teórico-conceitual a partir de alguns dos principais quadros teóricos e metodológicos de avaliação relevantes da literatura.

No escopo deste trabalho, apropriou-se da visão integrada defendida pela United Nations Development Programme (UNDP), para a tomada de decisão e gestão baseada em resultados (UNDP, 2009).

Arah et al (2003) apresentam uma comparação global das diversas abordagens de quadro teóricoconceitual (framework) dos sistemas de medição de performance do Reino Unido (NHS), do Canadá, da Austrália, dos EUA, do relatório World Health Report 2000 (WHO, 2000), além das publicações 'Health at a Glance e OECD Health Data' da Organisation for Economic Co-operation and Development (OECD) (DEVELOPMENT, 2001; UNIT, 2001) (MOITA; RAPOSO; BARBOSA, 2020).

Deve-se ressaltar que uma revisão da literatura mundial aponta que a satisfação do usuário é multifacetada e difícil de medir (ESPERIDIÃO; TRAD, 2005; ESPERIDIÃO, 2009), e, assim, em muitas pesquisas surgem resultados desconectados da realidade, ou seja, existem insatisfações dos usuários 
com os serviços recebidos, porém, pouco explicadas nos resultados das pesquisas, possivelmente, por falhas nas metodologias de mensuração (AHARONY; STRASSER, 1993 apud Esperidião e Trad, 2005: 304).

Nesse contexto, Vinagre (2008) enfatiza a complexidade da medição de serviços pelos aspectos de intangibilidade (ausência de atributos físicos) dos serviços (OLIVER, 1980; PARASURAMAN; BERRY; ZEITHAML, 1985a; 1991b) e o fato de que serviços são essencialmente processos, sendo afetados por interações e atividades, isto é, depende de aspectos relacionais entre usuários e provedores de serviços (GRÖNROOS, 1984a; 1988; GRÖNROOS, 1997; OLIVER, 1989; RUST; OLIVER, 1994; WESTBROOK, 1987; WESTBROOK, R. A; NEWMAN, JO. W; TAYLOR, J. R, 1978).

Por sua vez, Surprenant e Solomon (1987) afirmam que os serviços são concretizados pela experiência, e salientam a sua natureza interpessoal e relacional com enfoque no que alguns autores designam por encontro ou experiência de serviços, pressupondo que a produção e o consumo implicam a interação entre o utilizador, o prestador e a organização. Noutra visão, o modelo proposto por Bitner (1992 apud Vinagre 2008), caracteriza-se o encontro de serviços como a relação interpessoal e/ou inter-relacional entre usuário e prestador, a organização e o ambiente envolvente, enquanto a experiência de serviços como o resultado de um encontro ou de uma sequência destes que já ocorreram e nos quais se produziram múltiplas interações, que inclui as relações relativas ao ambiente, regras, normas e serviços fornecidos.

Diante dessas aparentes dificuldades e da necessidade de avaliar a satisfação dos usuários dos serviços de saúde, diversas metodologias têm sido desenvolvidas para estruturar uma escala de mensuração confiável de satisfação de usuários-pacientes, pelo que se caracterizam os aspectos positivos e as limitações das principais propostas que surgiram na pesquisa bibliográfica integrativa (tabela 1), a partir de uma análise integrativa realizada por Giese e Cote (2000 apud VINAGRE, 2008), que sintetizou achados de alguns estudos sobre as bases da avaliação da satisfação, comparando as definições conceituais, as respostas, o enfoque e o momento da análise da satisfação (MOITA, G. F; RAPOSO, V. M. R; BARBOSA, A. C. Q, 2019a), conforme a Quadro 1, abaixo.

Quadro 1 - Pesquisa integrativa de definições conceituais de satisfação de consumidores (usuáriosutilizadores) - ordenamento cronológico.

\begin{tabular}{|c|c|c|c|c|}
\hline Fonte & Definição conceitual & Resposta & Enfoque & Tempo \\
\hline $\begin{array}{l}\text { (PLICHON, } 1999 \text { citado } \\
\text { por LICHTLÉ; PLICHON, } \\
2005 \text { ) }\end{array}$ & $\begin{array}{l}\text { Estado afetivo proveniente dum processo de } \\
\text { avaliação afetivo e cognitivo que advém de } \\
\text { uma transação específica }\end{array}$ & $\begin{array}{l}\text { Estado } \\
\text { afetivo }\end{array}$ & $\begin{array}{l}\text { Transação } \\
\text { específica }\end{array}$ & Pós-consumo \\
\hline $\begin{array}{l}\text { (AURIER; EVRARD, } \\
\text { 1988) }\end{array}$ & $\begin{array}{l}\text { Um estado psicológico resultante do } \\
\text { processo de compra e de consumo }\end{array}$ & $\begin{array}{l}\text { Estado } \\
\text { psicológico }\end{array}$ & $\begin{array}{l}\text { Processo de } \\
\text { compra e de } \\
\text { consumo }\end{array}$ & \\
\hline (OLIVER, 1997) & $\begin{array}{l}\text { Resposta de utilização dos consumidores. É } \\
\text { um julgamento relativo que leva em } \\
\text { consideração tanto as qualidades (atributos) e } \\
\text { benefícios obtidos da aquisição, como os } \\
\text { custos e esforços do consumidor para } \\
\text { conseguir essa aquisição }\end{array}$ & $\begin{array}{l}\text { Resposta/jul } \\
\text { ga-mento de } \\
\text { realização }\end{array}$ & $\begin{array}{l}\text { Produto ou } \\
\text { serviço }\end{array}$ & $\begin{array}{l}\text { Durante ou pós- } \\
\text { consumo }\end{array}$ \\
\hline (OLIVER, 1997) & $\begin{array}{l}\text { Um julgamento de que o serviço forneceu } \\
\text { um nível agradável de realização relativa ao } \\
\text { consumo }\end{array}$ & $\begin{array}{l}\text { Julgamento } \\
\text { de realização }\end{array}$ & Serviço & Pós-consumo \\
\hline
\end{tabular}


Continuação

\begin{tabular}{|c|c|c|c|c|}
\hline Fonte & Definiçãoconceitual & Resposta & Enfoque & Tempo \\
\hline $\begin{array}{l}\text { (OSTROM; IACOBUCCL } \\
\text { 1995) }\end{array}$ & $\begin{array}{l}\text { A satisfação/insatisfação é um julgamento } \\
\text { relativo que leva em consideração tanto as } \\
\text { qualidades (atributos) e os benefícios obtido } \\
\text { da aquisição, como oscustos e esforços do } \\
\text { consumidor para conseguir essa aquisição. }\end{array}$ & $\begin{array}{l}\text { Julgamento } \\
\text { avaliativo } \\
\text { relativo }\end{array}$ & & \\
\hline (HALSTEADet al., 1994) & $\begin{array}{l}\text { Uma resposta afetiva relativa a uma } \\
\text { transação específica resultante da } \\
\text { comparação entre o desempenho do produtd } \\
\text { e determinados padrões de compra (idêntica } \\
\text { a HUNT, 1977; OLIVER, 1989) }\end{array}$ & $\begin{array}{l}\text { Resposta } \\
\text { afetiva }\end{array}$ & $\begin{array}{l}\text { Desempenho } \\
\text { por } \\
\text { comparação } \\
\text { a padrões } \\
\text { pré-compra }\end{array}$ & $\begin{array}{l}\text { Durante o } \\
\text { consumo }\end{array}$ \\
\hline (MANO; OLIVER, 1993) & $\begin{array}{l}\text { Satisfação (com um produto) é uma atitude } \\
\text { idêntica ao julgamento avaliativo pés } \\
\text { consumo (HUNT 1977) que varia ao longo de } \\
\text { um contínuo hedônico (ULIVER, 1989; } \\
\text { WESTBROOK OLIVER, 1991) }\end{array}$ & $\begin{array}{l}\text { Atitude- } \\
\text { julgamento } \\
\text { avaliativo } \\
\text { variando ao } \\
\text { longo de um } \\
\text { contínuo } \\
\text { hedônico }\end{array}$ & $\begin{array}{l}\text { Produto ou } \\
\text { serviço }\end{array}$ & Pós-consumo \\
\hline $\begin{array}{l}\text { (ANDERSON SULLIVAN } \\
\text { 1993) }\end{array}$ & $\begin{array}{l}\text { Uma avaliação póscompra da qualidade do } \\
\text { produto a partir das expectativas préompra }\end{array}$ & Avaliação & $\begin{array}{l}\text { Qualidade do } \\
\text { produto } \\
\text { Desconfirma } \\
\text { ção às } \\
\text { expectativas }\end{array}$ & Pós-compra \\
\hline (FORNELL, 1992) & $\begin{array}{l}\text { Uma avaliação global pósvenda. } \\
\text { Percepçãopóscompra Desconfirmação entre } \\
\text { o desempenho do produto e as expectativas }\end{array}$ & $\begin{array}{l}\text { Avaliação } \\
\text { global }\end{array}$ & $\begin{array}{l}\text { Desconfirma } \\
\text { ção entre o } \\
\text { desemp. do } \\
\text { produto e as } \\
\text { expectativas }\end{array}$ & Pós-consumo \\
\hline (OLIVER,1992) & $\begin{array}{l}\text { A satisfação é um somatório do fenômeno } \\
\text { atributivo com emoções de consumo }\end{array}$ & $\begin{array}{l}\text { Fenômeno } \\
\text { atributivo }+ \\
\text { emoções de } \\
\text { consumo }\end{array}$ & $\begin{array}{l}\text { Atributos do } \\
\text { produto }\end{array}$ & $\begin{array}{l}\text { Durante o } \\
\text { consumo }\end{array}$ \\
\hline $\begin{array}{l}\text { (WESTBROOK; OLIVER, } \\
\text { 1991) }\end{array}$ & $\begin{array}{l}\text { Julgamento avaliativo pósescolha referente } \\
\text { a uma seleção específica }\end{array}$ & $\begin{array}{l}\text { Julgamento } \\
\text { avaliativo }\end{array}$ & $\begin{array}{l}\text { Seleção de } \\
\text { compra } \\
\text { específica }\end{array}$ & Pós-escolha \\
\hline (OLIVER; SWAN, 1988) & $\begin{array}{l}\text { Sem definição conceitual, mas uma função } \\
\text { da justiça e desconfirmação }\end{array}$ & & Vendedor & $\begin{array}{l}\text { Durante a } \\
\text { compra }\end{array}$ \\
\hline (TSE; WiLton, 1988) & $\begin{array}{l}\text { A resposta do consumidor àvaliação da } \\
\text { discrepância percebida entre as expectativas } \\
\text { iniciais e o desempenho atual ou percebido } \\
\text { depois do consumo. }\end{array}$ & $\begin{array}{l}\text { Resposta a } \\
\text { uma } \\
\text { avaliação }\end{array}$ & $\begin{array}{l}\text { Discrepância } \\
\text { percebida } \\
\text { entre as } \\
\text { expectativas } \\
\text { prévias e o } \\
\text { desempenho }\end{array}$ & Pós-consumo \\
\hline (CADOTTE et al., 1987) & $\begin{array}{l}\text { Conceitualizada como uma sensação } \\
\text { desenvolvida através da avaliação de } \\
\text { experiência de utilização. }\end{array}$ & $\begin{array}{l}\text { Sensação } \\
\text { desenvolvida } \\
\text { pela } \\
\text { avaliação }\end{array}$ & $\begin{array}{l}\text { Experiência } \\
\text { de uso }\end{array}$ & $\begin{array}{l}\text { Durante o } \\
\text { consumo }\end{array}$ \\
\hline (WESTBROOK, 1987) & $\begin{array}{l}\text { Julgamento global avaliativo sobre o } \\
\text { consumo e uso do produto. }\end{array}$ & $\begin{array}{l}\text { Julgamento } \\
\text { global } \\
\text { avaliativo }\end{array}$ & $\begin{array}{l}\text { Utilização do } \\
\text { produto/cons } \\
\text { umo }\end{array}$ & $\begin{array}{l}\text { Durante o } \\
\text { consumo }\end{array}$ \\
\hline
\end{tabular}




\section{Continuação}

\begin{tabular}{|c|c|c|c|c|}
\hline Fonte & Definição conceitual & Resposta & Enfoque & Tempo \\
\hline (DAY, 1984) & $\begin{array}{l}\text { A resposta avaliativa a uma experiência de } \\
\text { consumo relativamente à discrepância } \\
\text { percebida entre as expectativas prévias e o } \\
\text { desempenho percebido(p.496). }\end{array}$ & $\begin{array}{l}\text { Resposta } \\
\text { avaliativa }\end{array}$ & $\begin{array}{l}\text { Discrepância } \\
\text { percebida } \\
\text { entre } \\
\text { expectativas } \\
\text { prévias e } \\
\text { desempenho }\end{array}$ & Pós-compra \\
\hline (BEARDEN; TEEL, 1983) & $\begin{array}{l}\text { Sem definição conceitual, mas uma função } \\
\text { das expectativas consideradas como crenças } \\
\text { de atributos dos produtos (já referido por } \\
\text { Olson e Dover, 1979) e da desconfirmação } \\
\text { (p. 22). }\end{array}$ & & & $\begin{array}{l}\text { Durante o } \\
\text { consumo }\end{array}$ \\
\hline $\begin{array}{l}\text { (LABARBERA; } \\
\text { MAZURSKY, 1983) }\end{array}$ & $\begin{array}{l}\text { Avaliação pós-compra: uma avaliação da } \\
\text { surpresa inerente à aquisição de um produto } \\
\text { ou à experiência de consumo citando de } \\
\text { Oliver (1981), (p.394). }\end{array}$ & Avaliação & Surpresa & $\begin{array}{l}\text { Pós-consumo ou } \\
\text { aquisição }\end{array}$ \\
\hline \multirow[b]{2}{*}{$\begin{array}{l}\text { (WESTBROOK; REILLY, } \\
\text { 1983) }\end{array}$} & $\begin{array}{l}\text { Uma resposta emocional a experiências de } \\
\text { consumo. }\end{array}$ & \multirow[b]{2}{*}{$\begin{array}{l}\text { Resposta } \\
\text { emocional }\end{array}$} & $\begin{array}{l}\text { Experiência } \\
\text { de consumo }\end{array}$ & \multirow[b]{2}{*}{ Pós-compra } \\
\hline & $\begin{array}{l}\text { Uma resposta emocional despoletada por um } \\
\text { processo de avaliaçãocognitiva de } \\
\text { desconfirmação das percepções ou crenças } \\
\text { sobre o produto ou serviço e os valores, } \\
\text { necessidades ou desejos do consumidor. }\end{array}$ & & $\begin{array}{l}\text { Percepções } \\
\text { (ou crenças) } \\
\text { sobre um } \\
\text { objeto, ação } \\
\text { comparada } \\
\text { com valores } \\
\text { individuais }\end{array}$ & \\
\hline $\begin{array}{l}\text { (CHURCHILL; } \\
\text { SURPRENANT, 1982) }\end{array}$ & $\begin{array}{l}\text { Um resultado de compra e utilização de um } \\
\text { produto por comparação com as } \\
\text { recompensas e custos da compra e } \\
\text { consequências antecipadas. Similar a atitude. }\end{array}$ & Resultado & $\begin{array}{l}\text { Comparação } \\
\text { das } \\
\text { recompensas } \\
\text { e custos } \\
\text { relativament } \\
\text { e às } \\
\text { consequênci } \\
\text { as } \\
\text { antecipadas }\end{array}$ & Pós-consumo \\
\hline \multirow{3}{*}{ (OLIVER, 1981A) } & \multirow{3}{*}{$\begin{array}{l}\text { Uma avaliação da surpresa inerente à } \\
\text { aquisição de um produto ou à experiência de } \\
\text { consumo. }\end{array}$} & Avaliação & Surpresa & \multirow{3}{*}{$\begin{array}{l}\text { Pós-consumo ou } \\
\text { compra }\end{array}$} \\
\hline & & $\begin{array}{l}\text { Estado } \\
\text { psicológico }\end{array}$ & \multirow{2}{*}{$\begin{array}{l}\text { Desconfirma } \\
\text { ção de } \\
\text { expectativas } \\
\text { em conjunto } \\
\text { com } \\
\text { sensações } \\
\text { prévias }\end{array}$} & \\
\hline & & Emoção & & \\
\hline \multirow[t]{2}{*}{$\begin{array}{l}\text { (SWAN; TRAWICK, } \\
1980)\end{array}$} & \multirow[t]{2}{*}{$\begin{array}{l}\text { Avaliação consciente ou julgamento } \\
\text { cognitivo do desempenho. A satisfação } \\
\text { envolve também afetos relativos a sensações } \\
\text { referentes aos produtos. }\end{array}$} & $\begin{array}{l}\text { Avaliação } \\
\text { consciente } \\
\text { ou } \\
\text { julgamentos } \\
\text { cognitivos }\end{array}$ & \multirow[t]{2}{*}{$\begin{array}{l}\text { Através do } \\
\text { produto }\end{array}$} & \multirow[t]{2}{*}{$\begin{array}{l}\text { Durante ou pós- } \\
\text { consumo }\end{array}$} \\
\hline & & $\begin{array}{l}\text { Dimensões } \\
\text { afetivas }\end{array}$ & & \\
\hline
\end{tabular}


Continuação

\begin{tabular}{|c|c|c|c|c|}
\hline Fonte & Definição conceitual & Resposta & Enfoque & Tempo \\
\hline (WESTBROOK, 1980A) & $\begin{array}{l}\text { Refere-se à avaliação subjetiva individual } \\
\text { favorável dos resultados e experiência de } \\
\text { consumo associada (citando Hunt, 1977). }\end{array}$ & $\begin{array}{l}\text { Avaliação } \\
\text { subjetiva } \\
\text { individual } \\
\text { favorável }\end{array}$ & $\begin{array}{l}\text { Resultados e } \\
\text { experiências }\end{array}$ & $\begin{array}{l}\text { Durante o } \\
\text { consumo }\end{array}$ \\
\hline (HuNT, 1977) & $\begin{array}{l}\text { Tipo de avaliação que considera que a } \\
\text { experiência é pelo menos tão boa quanto } \\
\text { deveria ser }\end{array}$ & $\begin{array}{l}\text { Avaliação da } \\
\text { experiência }\end{array}$ & $\begin{array}{l}\text { Experiência } \\
\text { foi pelo } \\
\text { menos tão } \\
\text { boa quanto } \\
\text { era suposto } \\
\text { ser }\end{array}$ & $\begin{array}{l}\text { Durante a } \\
\text { experiência de } \\
\text { consumo }\end{array}$ \\
\hline $\begin{array}{l}\text { (HOWARD; SHETH, } \\
\text { 1969) }\end{array}$ & $\begin{array}{l}\text { Estado cognitivo dos compradores } \\
\text { recompensados de forma adequada ou } \\
\text { desadequada em função do seu sacrifício }\end{array}$ & $\begin{array}{l}\text { Estado } \\
\text { cognitivo }\end{array}$ & $\begin{array}{l}\text { Ser } \\
\text { adequado ou } \\
\text { desadequado } \\
\text { à } \\
\text { recompensa } \\
\text { por } \\
\text { sacrifícios }\end{array}$ & \\
\hline (CARDOZO, 1965) & $\begin{array}{l}\text { Sem definição formal. Constatação de que a } \\
\text { satisfação deverá ser um conceito mais } \\
\text { global que a simples avaliação de um } \\
\text { produto, envolvendo também toda a } \\
\text { experiência de consumo, através da } \\
\text { desconfirmação/confirmação de expectativas } \\
\text { e avaliação de esforço dispendido (e outros } \\
\text { elementos a identificar em estudos } \\
\text { posteriores) }\end{array}$ & $\begin{array}{l}\text { Avaliação } \\
\text { Desconfirma } \\
\text { ção/confirma } \\
\text { ção das } \\
\text { expectativas. } \\
\text { Avaliação de } \\
\text { esforço } \\
\text { dispendido }\end{array}$ & $\begin{array}{l}\text { Produto e } \\
\text { experiência } \\
\text { de consumo }\end{array}$ & \\
\hline
\end{tabular}

Fonte: adaptado de Giese e Cote (2000 apud VINAGRE, 2008, p. 23-25).

Diante dos diferentes escopos possíveis para a análise da satisfação e da existência de diversas linhas diferentes de investigação da satisfação dos usuários no contexto de serviços, não sendo escopo desta investigação aprofundar suas bases teóricos-conceituais. Neste estudo elegeu-se o escopo de experiência de serviços, visto que dadas as características do atendimento em saúde, a experiência na saúde pode ser sensível aos constructos expectativas, emoções e experiências, que são constructos que estão na base do enquadramento teórico da linha experiência de serviços para mensuração da satisfação.

Vinagre (2008) ressalta que no ambiente de transações ou encontros de serviços específicos, muitos dos autores (p.ex. CHURCHILL, G.; SURPRENANT, C., 1982; OLIVER, 1980; OLIVER; DESARBO, 1988b) avaliam a satisfação a partir de seus preditores, e provam em seus estudos empíricos que estas variáveis preditoras influenciam, em menor ou maior grau, na satisfação e na qualidade percebida pelo usuário durante uma experiência de consumo do serviço.

Dessa forma, diante das muitas definições do constructo satisfação e dos inúmeros quadros conceituais (framework) propostos na literatura para a avaliação da satisfação, neste trabalho, resolveu-se abordar a satisfação enquanto resposta a um processo de avaliação da experiência de consumo, e considerar tanto o resultado quanto o processo como elementos importantes para a satisfação dos consumidores com enfoque nos antecedentes/preditores da satisfação, ou seja, amparado pela teoria da atribuição causal (BITNER; BOOMS; MOHR, 1994). 
Assim, a partir de um modelo geral (figura 2) os constructos expectativas, desconfirmação, desempenho e qualidade de serviços quase sempre constam dos modelos de mensuração da satisfação (por simplicidade metodológica utiliza-se esta linha teórica neste estudo), enquanto os constructos equidade, atribuição e emoções geralmente são abordados apenas em estudos mais elaborados sobre a satisfação.

Figura 2- Antecedentes da satisfação mais frequentemente utilizados.

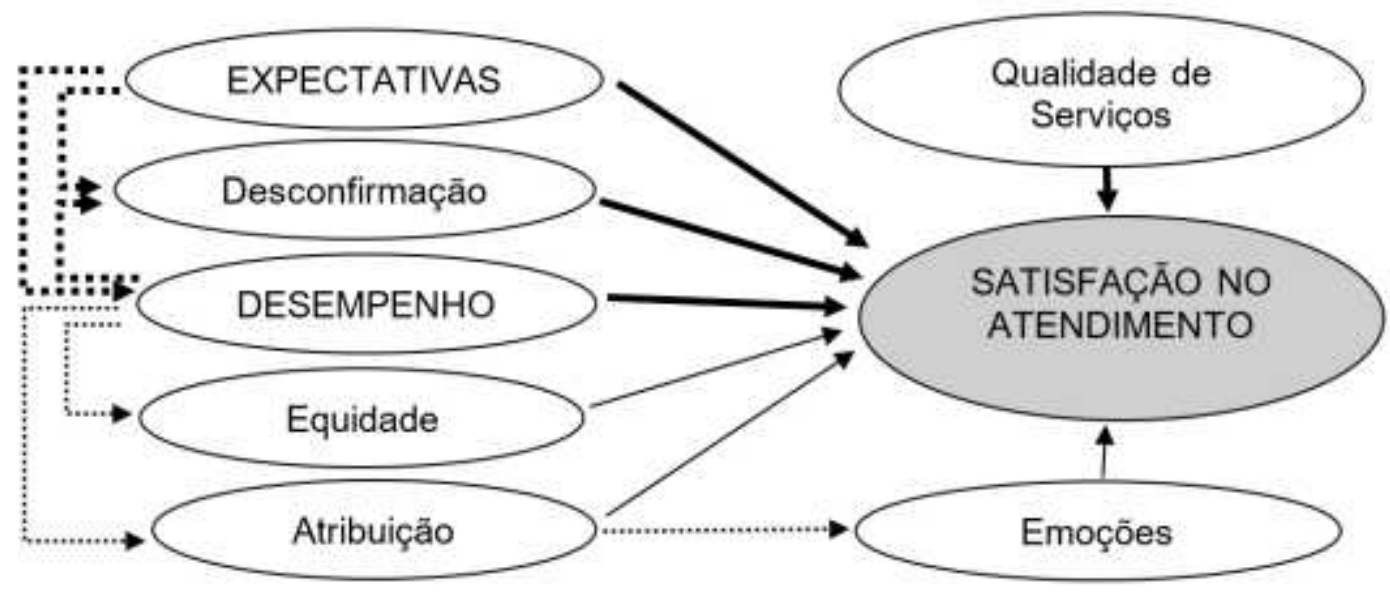

Fonte: adaptado de Szymanski e Henard (2001 apud Vinagre, 2008: 26).

Na verdade, tem-se um enorme desafio empírico no estudo da satisfação, em busca de identificar os preditores que são relevantes para compor a satisfação nos encontros de serviços. Ao compreender a expectativa como um dos mais importantes preditores da satisfação (SZYMANSKI; HENARD, 2001) afirmam ainda que o constructo expectativa é pouco consensual, além de existirem múltiplas classes de expectativas (p.ex. TSE; WILTON, 1988b; ZEITHAML; BERRY; PARASURAMAN, 1993a).

Um estudo muito relevante sobre preditores das expectativas de consumo foi apresentado por Oliver (1997) que desenhou um modelo (figura 3) que assume que as necessidades e valores são preditores dos desejos e que estes em conjunto (necessidades, valores e desejos) influenciam as expectativas dos consumidores.

Figura 3 - Inter-relações entre necessidades, valores e desejos versusexpectativas.

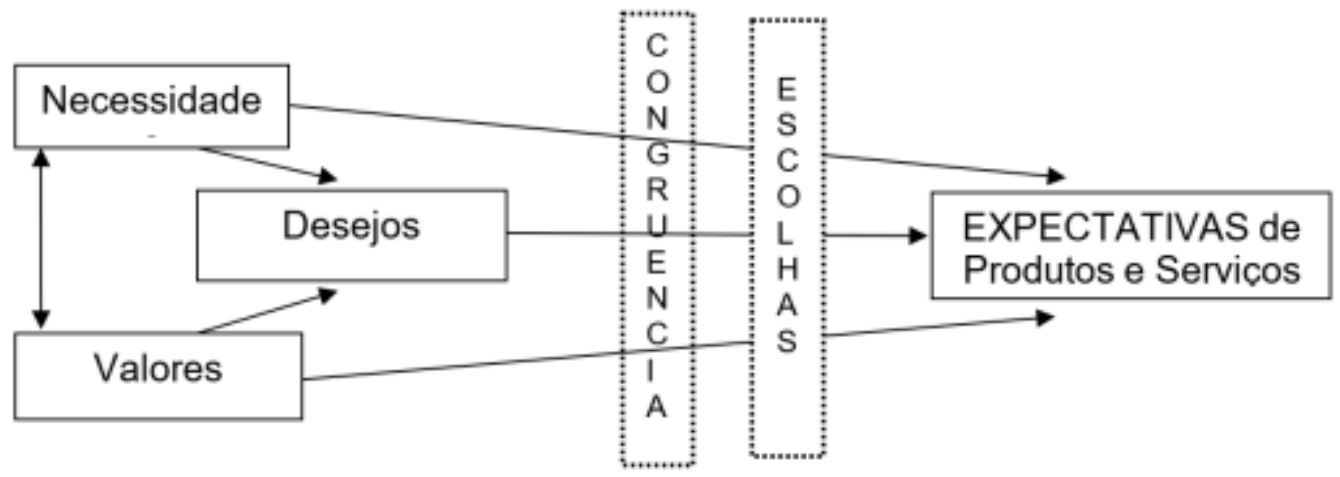

Fonte: Adaptado de (OLIVER, 1997 apud Vinagre, 2008: 29). 
Assim, Oliver (1997) assume que as necessidades e os valores do consumidores são preditores diretos dos desejos e da expectativa, e a conjugação destes (necessidades, valores e desejos) influenciam as expectativas dos consumidores. Teoriza ainda que estas inter-relações devem ser analisadas como sendo moderadas pelas congruências entre necessidades, valores e desejos, sempre buscada pelo consumidor, tendo ainda as escolhas de decisões de consumo como variável moderadora da formação da expectativa do consumidor.

Estes aprofundamentos de preditores são importantes, porém, para o escopo deste trabalho, resolveu-se partir da mensuração da expectativa e da percepção de desempenho e a desconfirmação objetiva (diferença algébrica) enquanto preditores da satisfação/insatisfação, baseados no figura 4, proposto por Oliver (1997).

Figura 4 - Modelo completo de desconfirmação das expectativas com o desempenho percebido.

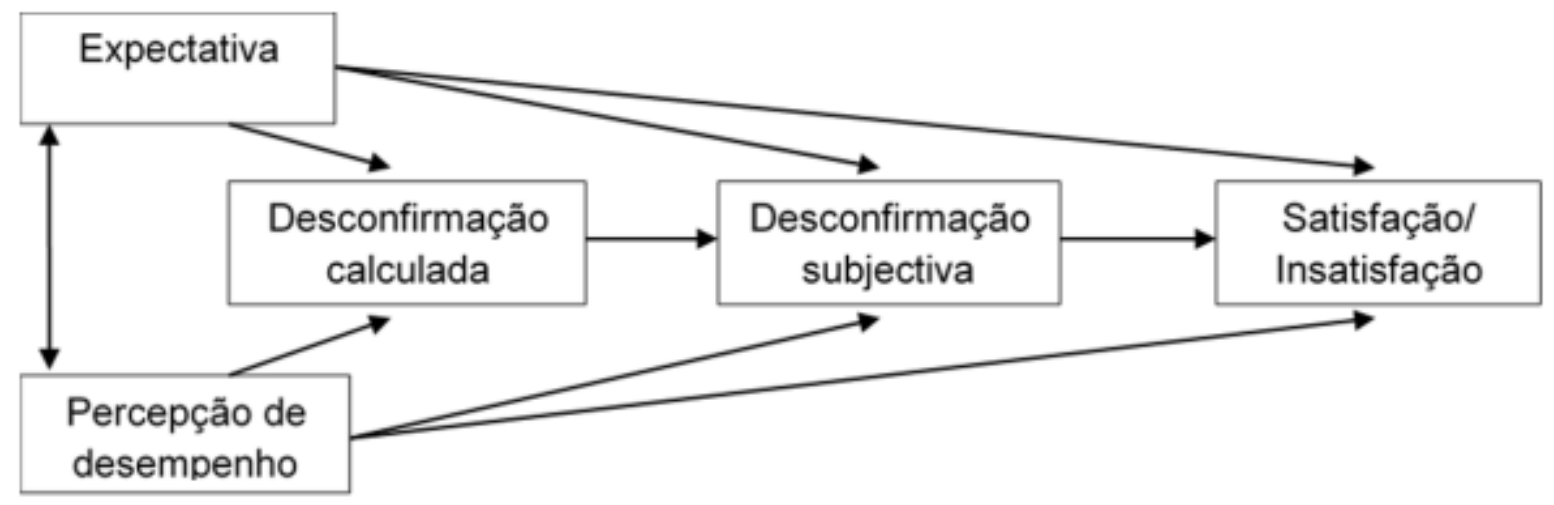

Fonte: Adaptado de (OLIVER, 1997 apud Vinagre, 2008: 29).

Segundo Vinagre (2008), as expectativas têm sido consideradas como antecipação ou como referente de comparação no contexto dos efeitos de desconfirmação. Enquanto antecipação da satisfação elas são tidas como influentes diretos da satisfação sem recurso comparativo com os níveis de percepção de desempenho (OLIVER; DESARBO, 1988b).

Surgem também alguns estudos empíricos (p.ex. CHURCHILL, G.; SURPRENANT, C., 1982; OLIVER; DESARBO, 1988b; YI, 1990) que comprovam que a desconfirmação é um importante determinante da satisfação, que sugerem que a desconfirmação terá de ser medida de forma independente enquanto determinante específico e separado das expectativas, pois teorizam que as expectativas se alteram no pós-consumo, fase em que a desconfirmação é medida efetivamente.

Noutros diferentes prismas há estudos empíricos que refutam a importância da desconfirmação e preferem a mensuração das expectativas como componente integrado da desconfirmação (KOPALLE; LEHMANN, 2001; MITTAL; ROSS; BALDASARE, 1998). Há também estudos empíricos que suportam relação positiva entre expectativas e satisfação (BEARDEN; TEEL, 1983; OLIVER; LINDA, 1981; SWAN; TRAWICK, 1981b). Por sua vez, Cronin e Taylor (1992) afirmam que as expectativas têm fraca saliência comparativamente com o desempenho percebido.

Há, ainda, estudos que utilizam a satisfação na condição de referente de comparação, que fundamentam o paradigma da desconfirmação, modelo de desconfirmação ou "gap model" (OLIVER, 1980; 1981a; b; PARASURAMAN; BERRY; ZEITHAML, 1985c; 1988b; 1991a; b; PARASURAMAN, A.; 
ZEITHAML, V.; BERRY, L., 1994; TSE; WILTON, 1988b; YI, 1990), que sustenta que os consumidores ficam satisfeitos se o desempenho percebido excede (desconfirmação positiva) ou iguala as expectativas (confirmação) e insatisfeitos se o desempenho observado é inferior as expectativas (desconfirmação negativa) (OLIVER, 1981b; OLIVER; DESARBO, 1988b). Assim, alguns estudos (OLIVER, 1980; 1981a; b; TSE; WILTON, 1988b; YI, 1990) explicam que os consumidores formariam expectativas pré-consumo, que quando comparadas com a percepção de desempenho no encontro de serviços, conduzem à confirmação/desconfirmação das expectativas.

Noutra perspetiva, Oliver e DeSarbo (1988b) destacam algumas das principais teorias propostas para o desenvolvimento da teoria da satisfação ou insatisfação de clientes/consumidores: Equity Theory; Attribution Theory; Performance Theory; e Expectancy Disconfirmation Theory (gap model), todas com vantagens e desvantagens.

Essas teorias foram concebidas no ambiente do marketing para estudos dos aspetos transacionais. $\mathrm{Na}$ Equity Theory relaciona-se ao princípio de que as saídas do processo de transação são proporcionais às entradas de cada uma das partes; na Attribution Theory pressupõe-se que a saída do processo de transação será avaliada em termos de sucesso ou de fracasso, e as causas destas saídas estão relacionadas a fatores internos, tais como as habilidades percebidas de compra ou de esforços, a fatores externos, como, por exemplo, a dificuldade relacionada ao processo de compra, ou a outros fatores, como a influência da equipe de vendas neste processo; na Performance Theory a satisfação do cliente está fortemente associada com a performance percebida do produto ou do serviço adquirido; e na Expectancy Disconfirmation Theory, talvez, a forma de mensuração de satisfação de clientes mais utilizada, parte-se do princípio de que os clientes criam um nível de expectativa em relação a produtos e serviços e que a desconfirmação (positiva ou negativa) pode gerar satisfação (desconfirmação positiva) ou insatisfação (desconfirmação negativa), definindo-se assim um "gap" ou hiato entre expectativa e satisfação do cliente (OLIVER, 1980; 1981a; b; TSE; WILTON, 1988b; YI, 1990), denominado de modelo "gap model".

Os estudos seminais das escalas psicométricas podem ter surgido no âmbito das relações de consumo (BABAKUS; FERGUSON JR.; JÖRESKOG, 1987; BABAKUS; FERGUSON JR., 1988; BERNHARDT; SHOSTACK, 1983; GRÖNROOS, 1984b; 2000; OLIVER; LINDA, 1981; PETER; CHURCHILL, 1986; WESTBROOK, ROBERT A.; NEWMAN, JOSEPH W.; TAYLOR, JAMES R., 1978; WESTBROOK; OLIVER, 1981).

Em seguida, voltou-se para analisar potenciais fatores mediadores da satisfação dos consumidores nasrelações comerciais, bancos e em empresas de serviços (GRÖNROOS, 1997; KANG; JEFFREY, 2004; OLIVER, 1980; 1989; 1993a; OLIVER; DESARBO, 1988a; OLIVER; LINDA, 1981; WESTBROOK, 1980; WESTBROOK; OLIVER, 1981; WESTBROOK; REILLY, 1983; ZEITHAML; BERRY; PARASURAMAN, 1993b; ZEITHAML; PARASURAMAN; BERRY, 1990). Em novo avanço buscou-se a extensão da influência dos fatores mediadores de percepção da qualidade de serviços e satisfação de consumidores (MANO; OLIVER, 1993; OLIVER, 1993b; 1994; 1996; OLIVER; DESARBO, 1988a; PARASURAMAN; GREWAL, 2000; PARASURAMAN, A.; ZEITHAML, V. A.; BERRY, L. L., 1994; SHEMWELL; YAVAS; BILGIN, 1998; WESTBROOK; OLIVER, 1991; ZEITHAML; BERRY; PARASURAMAN, 1993b).

Novas pesquisas inauguraram os modelos de validação de respostas aos ítens em escala semiestruturadas de qualidade e satisfação (BABAKUS; BOLLER, 1992; BABAKUS; FERGUSON JR.; JÖRESKOG, 1987; BABAKUS; FERGUSON JR., 1988; BABAKUS; PEDRICK; RICHARDSON, 1995; CHURCHILL, G. A.; SURPRENANT, C., 1982; CRONIN; BRADY; BRAND; HIGHTOWER JR. et al., 1997; 
CRONIN, J. J.; TAYLOR, A. S., 1992; KARATEPE; YAVAS; BABAKUS, 2005; OLIVER, 2010; SHEMWELL; YAVAS, 1999; WESTBROOK; OLIVER, 1991; WESTBROOK; REILLY, 1983; ZEITHAML; PARASURAMAN; BERRY, 1990).

$\mathrm{Na}$ evolução desses estudos surgiram as escalas psicosométricas para mensuração da qualidade percebida, baseadas no modelo de gap model de satisfação (OLIVER, 1980; OLIVER; LINDA, 1981; WESTBROOK; REILLY, 1983), nas quais a posição da percepção do cliente sobre a qualidade de serviço percebida depende da natureza e da extensão da discrepância entre a expectativa de serviço e a percepção de desempenho. Assim, foca-se na mensuração da distância entre a expectativa e a percepção de qualidade de serviços, com análise de pertinência e aplicações (BRADY; CRONIN, 2001; CRONIN; BRADY; HULT, 2000; PARASURAMAN; BERRY; ZEITHAML, 1988a; 1991a; PARASURAMAN, A.; ZEITHAML, V. A.; BERRY, L. L., 1994; SWAN; TRAWICK, 1980; 1981a).

Porém, um dos maiores desafios tem sido a modelagem das expectativas de serviço (serviço desejado, serviço adequado e serviço previsto), além de analisar seus possíveis antecedentes e variáveis preditoras, inclusive em serviços de saúde (BABAKUS; BIENSTOCK; VAN SCOTTER, 2004; BOWERS; SWAN; KOEHLER, 1994; OLIVER; SWAN, 1989; PARASURAMAN; BERRY; ZEITHAML, 1985a; TAYLOR; CRONIN, 1994; TSE; WILTON, 1988a; WESTBROOK; OLIVER, 1991; ZEITHAML; BERRY; PARASURAMAN, 1993b; ZEITHAML; PARASURAMAN; BERRY, 1990).

Em uma meta-análise sobre o assunto, Szymanski e Henard (2001) salientam que as investigações sobre satisfação de consumidores focam predominantemente os efeitos sobre a satisfação através das variáveis preditoras, quais sejam as expectativas, a desconfirmação (como preditor com efeito dominante) e, ainda, citam outros preditores como a equidade (como forte preditor, quando analisada conjuntamente com as expectativas e as emoções) e, a percepção (com um efeito preditor muito mais fraco, quando analisada conjuntamente com as expectativas de desempenho).

A perspectiva da avaliação da qualidade e/ou satisfação na metodologia do gap model é operacionalizada pela comparação algébrica entre expectativa do usuário e a satisfação percebida na qual a posição da percepção do cliente sobre a qualidade de serviço percebida depende da natureza e da extensão da discrepância entre a expectativa de serviço e o desempenho percebido pelo usuário, por exemplo, pela elaboração de um instrumento de mensuração de satisfação denominado de Escala Service Quality - SERVQUAL ${ }^{4}$. Nessa escala, foi proposta a medição de qualidade do serviço, baseado no modelo "gap model" (OLIVER, 1980; 1981a; b; TSE; WILTON, 1988b; YI, 1990) que, inicialmente, foi desenvolvida com 97 itens, com base nas 10 dimensões da qualidade (PARASURAMAN; BERRY; ZEITHAML, 1988a). Finalmente, um instrumento com 22 perguntas foi consolidado e redistribuído das dez (10) dimensões originais para as cinco (5) dimensões da escala SERVQUAL atuais (BABAKUS; BOLLER, 1992; BABAKUS, E.; MANGOLD, W. G., 1992a; BERRY; PARASURAMAN; ZEITHAML; ADSIT, 1994; PARASURAMAN; BERRY; ZEITHAML, 1991a), conforme quadros 2 e 3, a seguir. Albuquerque (2012) caracteriza estas cinco dimensões da seguinte forma:

\footnotetext{
4 Servqual - Escala Service Qualityde avaliação de qualidade e satisfação em serviços(Parasunaman e Zeithalm, 1988; 1991)
} 
1. Tangíveis visíveis: está relacionado à atratividade das instalações, equipamentos e materiais usados por uma empresa de serviços, bem como à aparência dos funcionários do serviço.

2. Confiabilidade/credibilidade: significa que a empresa de serviços oferece a seus clientes serviço correto da primeira vez, sem cometer nenhum erro, e entrega o que prometeu dentro do prazo estipulado.

3. Capacidade de resposta/prontidão: significa que os funcionários de uma empresa de serviços estão dispostos a ajudar os clientes e atender aos seus requisitos, bem como informá-los, quando o serviço será prestado e então executá-lo com presteza.

4. Segurança/domínio: significa que o comportamento dos empregados transmitirá aos clientes confiança na empresa e que esta faz com que se sintam seguros. E também que os empregados são sempre corteses e têm o conhecimento necessário para responder às perguntas dos clientes.

5. Empatia: Significa que a empresa entende os problemas dos clientes e executa o serviço, tendo em vista seus melhores interesses, bem como Ihes dá atenção pessoal, individual, e trabalha em horários convenientes.

Quadro 2- Equalização de 22 questões da escala SERVQUAL (10 dimensões originais para 5 dimensões atuais).

\begin{tabular}{|c|c|c|c|c|c|}
\hline \multicolumn{6}{|c|}{$\begin{array}{l}\text { Redistribuição das } 22 \text { Questões da Esca\$r RVQUAL } \\
\text { - } 10 \text { dimensões originais (linhas)s } 5 \text { dimensões atuais (colunas) }\end{array}$} \\
\hline & $\begin{array}{l}\text { Aspectos } \\
\text { Tangiveis }\end{array}$ & Confiabilidade & Presteza & Segurança & Empatia \\
\hline Aspectos tangíveis & Questões (1 a 4) & & & & \\
\hline Confiabilidade & & Questões (5 a 9) & & & \\
\hline Presteza & & & Questões (10 a 13) & & \\
\hline Competência & & & & \multirow{4}{*}{$\begin{array}{l}\text { Questões } \\
(14 \text { a } 17)\end{array}$} & \\
\hline Cortesia & & & & & \\
\hline Credibilidade & & & & & \\
\hline Segurança & & & & & \\
\hline Acessibilidade & & & & & \multirow{3}{*}{$\begin{array}{l}\text { Questões } \\
\text { (18 a 22) }\end{array}$} \\
\hline Comunicação & & & & & \\
\hline $\begin{array}{c}\text { Compreensão/ } \\
\text { Conhecimento do } \\
\text { cliente }\end{array}$ & & & & & \\
\hline
\end{tabular}

Fonte: Adaptado a patir de (PARASURAMAN; BERRY; ZEITHAML, 1988a). 
Quadro 3- Lista de 22 questões da escala SERVQUAL original

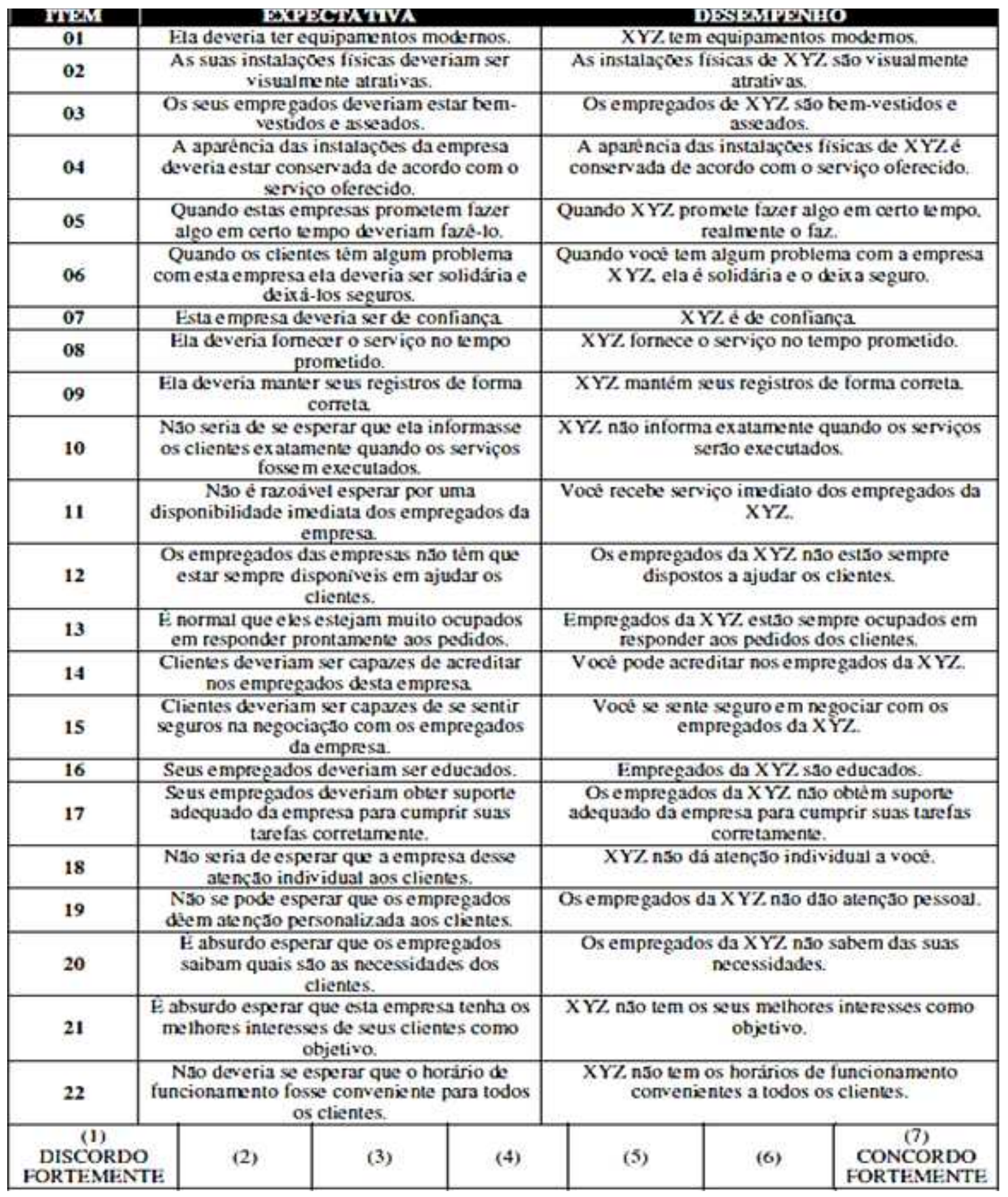

Fonte: Adaptado a patir de (PARASURAMAN; BERRY; ZEITHAML, 1988a).

Destaca-se a adaptação da escala SERVQUAL para aplicação em serviços de saúde (MANGOLD; BABAKUS, 1989; WESTBROOK; BABAKUS; GRANT, 2014; WESTBROOK; GRANT; RAFALSKI; BABAKUS, 2015; WESTBROOK; NEWMAN, 1978), concluíram que a escala SERVQUAL é confiável e válida no ambiente hospitalar e em outros serviços de saúde. Entretanto, deve-se reconhecer que há limitações relatadas na literatura (CHAHAL; KUMARI, 2011; 2012; CRONIN; TAYLOR, 1994; CRONIN, J. R. J.; TAYLOR, A. S., 1992), além da estruturação de outros instrumentos (FERREIRA, 1993; FERREIRA; LUZ; VALENTE; RAPOSO et al., 2001; FERREIRA; MENDES, 1997; FERREIRA; RAPOSO, 2006; FERREIRA; RAPOSO; PISCO, 2017; KARATEPE; YAVAS; BABAKUS, 2005; PEDRO; FERREIRA; MENDES, 2010). 
Neste processo, há de se considerar algumas limitações, restrições e cautelas na aplicação do instrumento e análise de resultados obtidos. Um exemplo de restrição analítica é que a qualidade de serviços observável ou perceptível é conceituada como um julgamento global, enquanto a satisfação é relacionada a um fato ou transação específica (PARASURAMAN; BERRY; ZEITHAML, 1985b).

Noutro prisma, ao comparar a escala SERVQUAL com outras escalas, por exemplo, a escala SERVPERF 5 (CRONIN, J. R. J.; TAYLOR, A. S., 1992), a escala SERVPERVAL (CHAHAL; KUMARI, 2011; 2012) e com o Instrumento de Avaliação de Qualidade Hospitalar (IAQH) (FERREIRA, 1993; FERREIRA; LUZ; VALENTE; RAPOSO et al., 2001; FERREIRA; MENDES, 1997; FERREIRA; RAPOSO, 2006; FERREIRA; RAPOSO; PISCO, 2017; PEDRO; FERREIRA; MENDES, 2010). Porém, deve-se reconhecer que há limitações relatadas na literatura (CHAHAL; KUMARI, 2011; 2012; CRONIN; TAYLOR, 1994; CRONIN, J. R. J.; TAYLOR, A. S., 1992).

$\mathrm{Na}$ verdade, qualquer que seja o método selecionado, enfrenta-se pelo menos três desafios na medição da expectativados clientes-consumidores. O primeiro deles reflete as dificuldades para investigar a fidedignidade e a validade de escalas usadas para medições diretas de constructos como a satisfação, que é um constructo complexo e multifacetado, e, reflete atributos de produtos ou de serviços, mas depende da relação preço/valor e imagens mentais do cliente (DILLON, 1997).

Outro desafio ocorre por usuários diferentes dar importâncias relativas diferentes para as diversas dimensões contidas na satisfação (produto, serviço, comunicação etc), e assim, para se calcular o índice de satisfação geral dos clientes-consumidores, há de se considerar as respostas a todas as variáveis apresentadas no modelo, bem como suas diferentes importâncias relativas.

Há, ainda, o desafio da necessidade de definição e inclusão de variáveis de "fechamento" de cada bloco/dimensão e da satisfação geral que visam estabelecer uma situação de dependência das variáveis para o emprego da técnica de análise estatística. Sem estas variáveis seria impossível estimar-se a importância de cada variável na satisfação com a análise de uma dimensão ou com a satisfação geral.

Além de medir a satisfação dos clientes-consumidores com cada atributo, um desafio adicional pode ser definir a importância relativa entre os atributos (FONTNOTE; HENKE; CARSON; CARSON, 2007), que pode ser obtida de duas formas: Declarada ou Derivada. A Importância Declarada é aquela na qual se solicita ao próprio entrevistado que avalie a importância dos atributos, para tal, geralmente se recorre a determinadas escalas, como a de diferencial semântico, de ranking e de soma constante; enquanto a Importância Derivada é obtida a partir da associação por métodos estatísticos entre a avaliação de cada atributo e a avaliação geral.

Quanto a seleção do método estatístico, Hanson (1992) sugere quatro formas a fim de analisar a Importância Derivada, ou seja, a mensuração de associação avaliação de cada atributo com a avaliação geral do usuário: pelo coeficiente de correlação de Pearson ( $r$ ); pelo coeficiente da regressão linear ( $\beta$ ); pela multiplicação do coeficiente da regressão linear $(\beta)$ e o coeficiente de correlação de Pearson ( $r$ ); e, pelo coeficiente de determinação parcial.

Dessa forma, nesta investigação mediu-se a Importância Declarada por uma escala de Likert de 5 níveis (diferencial semântico) além dos cálculos da Importância Derivada através de técnicas de estatística descritiva e inferencial para avaliar os itens da escala de qualidade percebida concebida.

Diante dessa evolução de modelos e quadros conceituais (framework), os estudos das escalas de mensuração de qualidade em serviços e satisfação de usuários está consolidado em diversos campos, 
podendo ser um campo de interesse, visto que, no Brasil, ainda não se registra nenhuma metodologia consolidada e/ou usada em larga escala dentro do escopo de satisfação desta investigação (quadro 4).

Pode-se destacar a iniciativa do Ministério do Planejamento do Brasil (BRASIL, 2009), pautado pelo Decreto no 5.378/2005 (BRASIL, 2005), que propôs a criação do Instrumento Padrão de Pesquisa e Satisfação (IPPS) tendo analisado três metodologias internacionais (o American Consumer Satisfaction Index da Universidade de Michigan; o SERVQUAL - dos especialistas Zeithaml, Parasuraman e Berry- e também do Common Measurement Tool do Centro Canadense de Gestão), no âmbito do Programa Nacional da Gestão Pública e Desburocratização - Gespública (BRASIL, 2010), através de um questionário do IPPS (BRASIL, 2014), com aparentes similaridades com as cinco dimensões propostas (Tangibilidade, Confiabilidade, Capacidade de resposta, Segurança e Empatia) e suas 22 questões da escala SERVQUAL (PARASURAMAN; BERRY; ZEITHAML, 1991a; 1994). Entretanto, não se localizou publicações recentes sobre o IPSS, talvez por descontinuidade da iniciativa.

Nesse escopo, há três trabalhos de pequeno porte de aplicação da SERVQUAL em contextos específicos (HERCOS; BEREZOVSKY, 2004; BORGES, et al., 2006; CRUZ \& MELLEIRO, 2007). Também foram identificados outros três trabalhos com sistematização da escala SERVQUAL para aplicação em ambientes hospitalares, mas com traduções e adaptações simplificadas e a plicação em amostra resumida em hospitais do Brasil (ALBUQUERQUE, 2012; DA SILVA, 2014; ROSALEM, 2013).

No estudo de Albuquerque (2012) a escala SERVQUAL foi aplicada no ambiente de seis hospitais gerais, vinculados ao SUS. Os resultados sugerem que a utilização da avaliação dos serviços pode apoiar aos gestores e profissionais a mensurar a qualidade de serviço através da identificação e análise de suas dimensões.

Por sua vez, Rosalem (2013) aplicou a SERVQUAL para mensurar a percepção no ambiente de hospitais gerais, vinculados ao SUS, sendo 10 públicos e 10 privados. Os resultados apontaram a adequação da aplicação da escala SERVQUAL e forte diferenciação da percepção de qualidade entre hospitais públicos e privados e também entre os três grupos de entrevistados: gestores, profissionais e pacientes.

Por fim, os estudos de Da Silva (2014) avaliou a percepção de qualidade e satisfação com pacientes de unidades clínicas e cirúrgicas do Hospital da Universidade de Sergipe, sendo que as cinco dimensões e os 22 atributos das questões da Escala SERVQUAL aplicadas apresentaram as diferenças entre Percepção e Expectativa negativas e próximas de zero, ou seja, não se verificou a associação negativa citada pela literatura de aplicação da escala SERVQUAL (BABAKUS, E.; MANGOLD, W. G., 1992b; PARASURAMAN; BERRY; ZEITHAML, 1988b; 1991a; PARASURAMAN, A.; ZEITHAML, V.; BERRY, L., 1994). Destacou ainda que a Empatia foi considerada a dimensão de maior importância, seguida da dimensão Confiabilidade, enquanto a Tangibilidade obteve a menor importância.

Esses trabalhos aplicaram apenas a versão original da escala SERVQUAL, sendo de difícil mensuração dos resultados comparativos pela ausência de validação transcultural. Essas pesquisas mencionadas parecem não servir bem aos seus propósitos, visto que não foram aplicados métodos científicos com rigor metodológico para a tradução e adaptação da escala SERVQUAL que realmente se aproximassem da realidade, sendo comparados no quadro 4, abaixo. 
Quadro 4 - Síntese de aplicação da escala SERVQUAL em organizações hospitalares e unidades de saúde do Brasil.

\begin{tabular}{|c|c|c|c|c|c|}
\hline $\begin{array}{c}\text { Autores/ Título } \\
\text { Resumido }\end{array}$ & $\begin{array}{l}\text { População / } \\
\text { Objeto do } \\
\text { Estudo }\end{array}$ & Local e Ano & $\begin{array}{c}\text { Amostra } \\
\text { (N) }\end{array}$ & $\begin{array}{l}\text { Tipo de } \\
\text { Análise }\end{array}$ & Descrição e Conclusões \\
\hline $\begin{array}{l}\text { Hercos, B. V. S. e } \\
\text { Berezovsky, A. } \\
\text { Qualidade do serviço } \\
\text { oftalmológico } \\
\text { prestado aos } \\
\text { pacientes } \\
\text { ambulatoriais, do } \\
\text { Sistema Único de } \\
\text { Saúde - SUS. }\end{array}$ & $\begin{array}{l}\text { Pacientes } \\
\text { ambulatoriais } \\
\text { do SUS } \\
\text { - Fundação } \\
\text { Hilton } \\
\text { Rocha. }\end{array}$ & $\begin{array}{l}\text { Belo } \\
\text { Horizonte, } \\
\text { Minas } \\
\text { Gerais, } \\
\text { Brasil - } \\
2004 .\end{array}$ & $\begin{array}{l}100 \\
\text { pacientes }\end{array}$ & $\begin{array}{l}\text { Escala } \\
\text { SERVQUAL } \\
\text { adaptada }\end{array}$ & $\begin{array}{l}\text { O grau de insatisfação com o serviço } \\
\text { prestado foi discreto principalmente na } \\
\text { dimensão segurança. Foi detectado que é na } \\
\text { confiabilidade a maior deficiência. Os dados } \\
\text { obtidos sugerem que monitorar a qualidade } \\
\text { do serviço, através do emprego periódico da } \\
\text { Escala SERVQUAL permite planejar } \\
\text { estratégias de intervenção de alta efetividade } \\
\text { como monitorar respostas a essas ações. }\end{array}$ \\
\hline $\begin{array}{l}\text { Borges, J. B. C. et al. } \\
\text { Qualidade do serviço } \\
\text { prestado aos pacientes } \\
\text { de cirurgia cardíaca do } \\
\text { Sistema Único de } \\
\text { Saúde - SUS }\end{array}$ & $\begin{array}{l}\text { Pacientes de } \\
\text { cirurgia } \\
\text { cardíaca da } \\
\text { Santa Casa de } \\
\text { Misericórdia. }\end{array}$ & $\begin{array}{l}\text { Marília, São } \\
\text { Paulo, } \\
\text { Brasil - } \\
2006 .\end{array}$ & $\begin{array}{l}82 \\
\text { Pacientes }\end{array}$ & $\begin{array}{l}\text { Analise e } \\
\text { modelo } \\
\text { SERVQUAL }\end{array}$ & $\begin{array}{l}\text { O paciente de cirurgia cardíaca tem } \\
\text { expectativa alta quanto ao serviço médico - } \\
\text { hospitalar. Ele da importância à dimensão } \\
\text { segurança não sendo relevante a } \\
\text { tangibilidade e confiabilidade. Os dados } \\
\text { obtidos sugerem que a qualidade deste } \\
\text { serviço pode ser monitorada periodicamente } \\
\text { pela Escala SERVQUAL }\end{array}$ \\
\hline $\begin{array}{l}\text { Cruz, W. B. S. e } \\
\text { Melleiro, } \\
\text { M. M. Análise da } \\
\text { satisfação dos usuários } \\
\text { de um hospital privado. }\end{array}$ & $\begin{array}{l}\text { Usuário em } \\
\text { unidades de } \\
\text { Internação de } \\
\text { clinica médica } \\
\text { e cirúrgica. }\end{array}$ & $\begin{array}{l}\text { São Paulo, } \\
\text { Brasil - } \\
2007\end{array}$ & $\begin{array}{l}71 \\
\text { usuários }\end{array}$ & $\begin{array}{l}\text { Escala } \\
\text { SERVQUAL }\end{array}$ & $\begin{array}{l}\text { Quanto às dimensões confiabilidade, } \\
\text { responsabilidade e empatia, todas foram } \\
\text { valorizadas pelos usuários, principalmente } \\
\text { relacionada ao desempenho dos } \\
\text { colaboradores. Quanto à dimensão } \\
\text { tangibilidade esta apresentou os menores } \\
\text { índices de satisfação. }\end{array}$ \\
\hline $\begin{array}{l}\text { Albuquerque, J. D. } \\
\text { (2012). Qualidade } \\
\text { hospitalar: Uma análise } \\
\text { da sua realidade em } \\
\text { Campina Grande - } \\
\text { Paraíba - Brasil. }\end{array}$ & $\begin{array}{l}\text { Pacientes, } \\
\text { profissionais e } \\
\text { gestores de seis } \\
\text { hospitais } \\
\text { vinculados ao } \\
\text { SUS. }\end{array}$ & $\begin{array}{l}\text { Campina } \\
\text { Grande, } \\
\text { Paraiba, } \\
\text { Brasil - } \\
2012 .\end{array}$ & $\begin{array}{l}495 \\
\text { indivíduos } \\
\text { (185 } \\
\text { profissiona } \\
\text { is e } 310 \\
\text { pacientes) }\end{array}$ & $\begin{array}{l}\text { Escala } \\
\text { SERVQUAL } \\
\text { traduzida (15 } \\
\text { questões) }\end{array}$ & $\begin{array}{l}\text { A expectativa foi superior a Percepção nas } \\
15 \text { questões aplicadas aos pacientes. A } \\
\text { Análise Fatorial Confirmatória validou } \\
\text { apenas três fatores (F1: Segurança, (F2: } \\
\text { Empatia e F3: Tangibilidade), tendo } \\
\text { apresentado apenas validade convergente e } \\
\text { discriminantes. }\end{array}$ \\
\hline $\begin{array}{l}\text { Rosalem, V. (2013). } \\
\text { Análise das percepções } \\
\text { dos principais atores da } \\
\text { cadeia produtiva da } \\
\text { saúde sobre a qualidade } \\
\text { dos serviços prestados } \\
\text { por hospitais no Estado } \\
\text { de Goiás - Brasil. }\end{array}$ & $\begin{array}{l}\text { Pacientes, } \\
\text { profissionais e } \\
\text { gestores de vinte } \\
\text { hospitais } \\
\text { vinculados ao } \\
\text { SUS. }\end{array}$ & $\begin{array}{l}\text { Goiás, Brasil } \\
-2013 \text {. }\end{array}$ & $\begin{array}{l}347 \\
\text { indivíduos } \\
(115 \\
\text { gestores, } \\
116 \\
\text { profissiona } \\
\text { is e } 116 \\
\text { pacientes })\end{array}$ & $\begin{array}{l}\text { Escala } \\
\text { SERVQUAL } \\
\text { traduzida ( } 22 \\
\text { questões) }\end{array}$ & $\begin{array}{l}\text { Os resultados sugerem que determinadas } \\
\text { diferenças de percepções, se trabalhadas por } \\
\text { grupos de interesse. Por exemplo, a } \\
\text { dimensão presteza, considerada a mais } \\
\text { importante pelos pacientes/usuários, poderia } \\
\text { ser melhorada entre os profissionais de } \\
\text { saúde que a relegaram como sendo uma das } \\
\text { menos importantes. Também houve } \\
\text { existência de diferenças significantes das } \\
\text { percepções sobre a qualidade por par te dos } \\
\text { grupos envolvidos, exceto para } \\
\text { profissionais. }\end{array}$ \\
\hline $\begin{array}{l}\text { Da Silva, F. J. C. P. } \\
\text { (2014). Avaliação da } \\
\text { qualidade do serviço de } \\
\text { saúde: a visão do } \\
\text { cliente }\end{array}$ & $\begin{array}{l}\text { Pacientes de } \\
\text { unidades } \\
\text { clínicas e } \\
\text { cirúrgicas do } \\
\text { Hospital da } \\
\text { Universidade de } \\
\text { Sergipe. } \\
\end{array}$ & $\begin{array}{l}\text { Ribeirão } \\
\text { Preto, São } \\
\text { Paulo, Brasil, } \\
2014 .\end{array}$ & $\begin{array}{l}305 \\
\text { pacientes }\end{array}$ & $\begin{array}{l}\text { Escala } \\
\text { SERVQUAL } \\
\text { adaptada (três } \\
\text { subescalas) }\end{array}$ & $\begin{array}{l}\text { As cinco dimensões e seus } 22 \text { atributos } \\
\text { apresentaram resultados negativos e } \\
\text { próximos de zero. Empatia foi considerada a } \\
\text { dimensão de maior importância, seguida da } \\
\text { dimensão confiabilidade enquanto a } \\
\text { tangibilidade foi a menor. }\end{array}$ \\
\hline
\end{tabular}

Fonte: Elaboração própria a partir de (MOITA, 2019b; c). 
serviços públicos de saúde no Brasil, nesta investigação elaborou-se uma proposta de estratégia de mensuração de avaliação de satisfação dos usuários-utilizadores, pautada em princípios científicos, embasada na tradução e validação transcultural multicêntrica da escala SERVQUAL.

Dessa forma, na linha teórica que se assumiu na presente investigação (Expectancy Disconfirmation Theory) abordou-se a qualidade percebida do serviço baseada no "modelo de discrepância" ou "gap model" adotado por diversos autores (OLIVER, 1980; 1981a; b; PARASURAMAN; BERRY; ZEITHAML, 1985c; 1988b; 1991a; b; PARASURAMAN, A.; ZEITHAML, V.; BERRY, L., 1994; TSE; WILTON, 1988b; YI, 1990), mais especificamente na discrepância entre expectativa (pré-consumo) e desempenho percebido (pós-consumo).

Nesta investigação a partir das 10 dimensões e das 22 questões originais da escala SERVQUAL, através de painéis de especialistas e grupos pilotos de profissionais, gestores e usuários, no âmbito de hospitais, policlínicas, unidades especializadas da rede de saúde, esses atores chaves estabeleceram constructos de qualidade e questões validadas classificadas em cinco macrodimensões similares as da escala SERVQUAL (Tangibilidade, Confiabilidade, Segurança, Presteza e Empatia), além de sinalizar a importância de uma nova macrodimensão denominada de Acessibilidade com aspetos de garantia de acesso oportuno, efetivo e eficaz ao atendimento em saúde.

Assim, o marco teórico construído nesse estudo norteou os pesquisadores quanto a validação dos ítens de avaliação de qualidade e satisfação, segundo a importância atribuída por gestores e decisores de saúde, mas, nesta etapa, buscou-se mapear os conhecimentos prévios dos respondentes, sem fazer vínculos com a literatura, que foram diretrizes para aprofundamentos em etapas posteriores.

A inclusão dos diversos atores na decisão da modelagem da avaliação se faz necessária também pela variedade de dimensões mensuráveis nos serviços de saúde, e pela necessidade de priorização por seus futuros utilizadores. Este estudo envolveu 195 especialistas e profissionais de 10 estados do Brasil (Bahia, Ceará, Goiás, Maranhão, Mato Grosso, Pará, Piauí, Rio Grande do Norte, Rondônia e o Distrito Federal), além de 506 usuários do SUS, operacionalizada em três fases sucessivas (painel de especialistas, grupos $D e l p h i^{6}$ e pesquisa de campo), cuja respostas foram objetos de análise descritiva e de significância estatística e aplicou entrevistas em 2.547 usuários de 74 unidades do SUS, que tiveram análises de confiabilidade e validade e consolidou um modelo final que se transformaram em 20 questões sobre qualidade e satisfação de usuários dosus.

Na pesquisa inicial estudaram-se as questões da escala SERVQUAL que tiveram os constructos (ideias-forças) representativos das 22 questões originais validadas e consolidados por meio da construção e validação científica de 20 questões (MOITA, 2019b; c) sendo base para desenvolvimento de uma plataforma virtual (Quality SaúdeTM) para a aplicação on-line em grupos multicêntricos de usuários do SUS (MOITA, G. F; RAPOSO, V. M. R; BARBOSA, A. C. Q, 2019a; MOITA, G. F.; RAPOSO, V. M. R.; BARBOSA, A. C. Q., 2019).

\footnotetext{
6 Técnica de grupo focal usada para obter consenso a respeito de um projeto.
} 
Em seguida, na terceira fase da pesquisa, um novo instrumento foi validado pela percepção e experiência de usuários do SUS, com 20 questões adaptadas, 13 subdimensões e seis macrodimensões de qualidade/satisfação, que foi aplicado para consolidar os o instrumento de qualidade percebida quanto aos níveis de preferências (relevâncias/importâncias) de 506 usuários em atendimento, de 15 unidades de saúde de um grande município da região metropolitana de Fortaleza (resultados em publicação).

A adaptação da escala SERVQUAL que gerou uma escala inovadora (Quality Saúde ${ }^{T M}$ ), permite que a percepção do usuário seja vista em contraponto à sua expectativa, apresentando resultados que realmente aproximam a realidade, além de destacar quais pontos devem ser revistos pelos gestores públicos. Desta forma, o processo aplicado pode ser expandido para outros serviços públicos, visando estruturar e validar painéis de indicadores específicos. 


\section{REFERÊNCIAS}

AHARONY, L.; STRASSER, S. Patient satisfaction: what we know about and what we still need to explore. Medical Care Review. Medical Care Review. 50: 31 p. 1993.

ALBUQUERQUE, J. D. Qualidade hospitalar: Uma análise da sua realidade em Campina Grande - Paraíba - Brasil. 2012. Doctoral -, Universidade de Extramadura, Espanha: Badajoz.

ARAH, O. A.; CUSTERS, T.; KLAZINGA, N. S. Updating the Key Dimensions of Hospital Performance: The Move Towards a Theoretical Framework In: 3rd Workshop on Hospital Performance Measurement 2003, Barcelona. WHO Regional Office for Europe.

ARAH, O. A.; KLAZINGA, N. S.; DELNOIJ, D. M. J.; ASBROEK, A. H. A. T. et al. Conceptual frameworks for health systems performance: a quest for effectiveness, quality, and improvement International Journal for Quality in Health Care, 15, n. 5, p. 22, 2003.

ARAH, O. A.; WESTERT, G. P.; HURST, J.; NIEK, S. et al. A conceptual framework for the OECD Health Care Quality Indicators Project International Journal for Quality in Health Care, p. 9, 2006.

BABAKUS, E.; BIENSTOCK, C. C.; VAN SCOTTER, J. R. Linking perceived quality and customer satisfaction to store traffic and revenue growth. Decision Sciences, 35, n. 4, p. 25, 2004.

BABAKUS, E.; BOLLER, G. W. An empirical assessment of the SERVQUAL scale. Journal of Business Research, 24, p. $16,1992$.

BABAKUS, E.; FERGUSON JR., C. E.; JÖRESKOG, K. G. The sensitivity of confirmatory maximum likelihood factor analysis to violations of measurement scale and distributional assumptions. Journal of Marketing Research, 24, $n$. 2, p. 7, 1987.

BABAKUS, E.; FERGUSON JR., C. E. On choosing the appropriate measure of association when analyzing rating scale data. Journal of the Academy of Marketing Science, 16, n. 1, p. 8, 1988.

BABAKUS, E.; MANGOLD, G. Adapting SERVQUAL Scale Hospital Service: Na empirical Investigation. Health Services Research. Health Services Research. 221992.

BABAKUS, E.; MANGOLD, W. G. Adapting the SERVQUAL scale to hospital services: an empirical investigation. Health Services Research, 26, n. 6, p. 20, 1992a.

BABAKUS, E.; MANGOLD, W. G. Adapting the SERVQUAL scale to Hospital Services: An empirical investigation. Health Services Research, 26, n. 6, p. 767-786, 1992b.

BABAKUS, E.; PEDRICK, D.; RICHARDSON, A. Assessing perceived quality in industrial service settings: measure development and application. Journal of Business-to-Business Marketing, 2, n. 3, p. 21, 1995.

BATISTA, W. J.; PAIVA, A. D. A utilização do instrumento padrão de pesquisa de satisfação (IPPS) no diagnóstico de uma organização militar de saúde do Exército Brasileiro. In: XI Simpósio de Excelência em Gestão e TecnologiaSEGeT 2014, Resende-RJ.

BEARDEN, W. O.; TEEL, J. E. Selected determinants of consumer satisfaction and complaint reports. JMR, Journal of Marketing Research, 20, n. 1, p. 1, 1983.

BERNHARDT, K. L.; SHOSTACK, G. Comments on Christian Grönroos' Strategic Management and Marketing in the Service Sector. Boston: 1983. 
BERRY, L. L.; PARASURAMAN, A.; ZEITHAML, V.; ADSIT, D. Improving service quality in America: Lessons learned; Executive commentary. The Academy of Management Executive, 8, n. 2, p. 21, 1994.

BITNER, M. J. Evaluating service encounters: the effects of physical surroundings and employees. Journal of Marketing, 56, n. 2, 1992.

BITNER, M. J.; BOOMS, B. H.; MOHR, L. A. Critical service encounters: The employee's viewpoint. Journal of Marketing, 58, n. 4, p. 1, 1994.

BORGES, J. B. C.; CARVALHO, S. M. R.; SILVA, M. A. M. Qualidade do serviço prestado aos pacientes de cirurgia cardíaca do Sistema Único de Saúde -SUS. Revista Brasileira de Cirurgia Cardiovascular, n. 25, 2006.

BOWERS, M. R.; SWAN, J. E.; KOEHLER, W. F. What attributes determine quality and satisfaction with healthcare delivery? Healthcare Management Review, 19, n. 4, p. 49-55, 1994.

BRADY, M. K.; CRONIN, J. J. Some new thoughts on conceptualizing perceived service quality: a hierarchical approach. Journal of Marketing, 65, p. 17, 2001.

BRASIL. A Saúde na opinião dos brasileiros. Ministério da Saúde. Brasília. 2003.

BRASIL. Decreto no 5.378, de 23 de fevereiro de 2005. CASA CIVIL, P. D. R. Distrito Federal: Brasília: Diário Oficial da União 2005.

BRASIL. MPOG - Guia Referencial para Medição de Desempenho e Manual para Construção de Indicadores. Brasília: Secretaria de Gestão, 2009.

BRASIL. Programa Nacional de Gestão Pública e Desburocratização - GESPÚBLICA. Manual de Avaliação de Satisfação do Usuário do Serviço Público. Ministério do Planejamento, Orçamento e Gestão. Secretaria de Gestão Pública. Brasília. 2010.

BRASIL. Portaria no 1.654 GM/MS, de 19 de julho 2011. Dispõe sobre o Programa Nacional de Melhoria do Acesso e da Qualidade da Atenção Básica (PMAQ-AB). Diário Oficial da União, Distrito Federal: Brasília, pp.

BRASIL. Autoavaliação para a Melhoria do Acesso e da Qualidade da Atenção Básica: AMAQ. Ministério da Saúde. Brasília. 2012a.

BRASIL. Programa Nacional de Melhoria do Acesso e da Qualidade da Atenção Básica (PMAQ): manual instrutivo. Ministério da Saúde. Brasília, p. 62. 2012b.

BRASIL. Índice de Desempenho do Sistema Único de Saúde. SAÚDE, M. D.: Ministério da Saúde 2012c.

BRASIL. Governos Estaduais no Federalismo Brasileiro. REPÚBLICA, S. D. A. E. D. P. D. Brasilia: Instituto de Pesquisa Econômica Aplicada: 335 p. 2014.

BRASIL. Portaria no 28, de 08 de janeiro de 2015. Diário Oficial da União, Distrito Federal: Brasília, pp.

BRASIL. Autoavaliação para melhoria do acesso e da qualidade da atenção básica: AMAQ. SAÚDE, M. D. Brasília: Ministério da Saúde, Secretaria de Atenção à Saúde, Departamento de Atenção Básica 164 p. 2017 a.

BRASIL. Decreto no 9.094, 17 de julho de 2017. Diário Oficial da União, Distrito Federal: Brasília, pp.

BRASIL. Lei no 13.460, de 26 de junho de 2017. Diário Oficial da União, Distrito Federal: Brasília, pp.

BRASIL. Manual instrutivo para as equipes de atenção básica e NASF - Programa Nacional de Melhoria do Acesso e da Qualidade da Atenção Básica (PMAQ) - Terceiro ciclo - (2015-2017). SAÚDE, M. D. Brasília: Ministério da Saúde, Secretaria de Atenção à Saúde, Departamento de Atenção Básica 2017d.

BRASIL. Catálogo de serviços públicos de atendimento do governo federal. Escola Nacional de Administração Pública. Brasília. 2018. 
CFM. Pesquisa revela que 92\% da população está insatisfeita com a saúde no Brasil. 2014. Disponível em: http://portal.cfm.org.br/index.php?option=com_content\&view=article\&id=24984:datafolha-revela-93-dapopulacao-esta-insatisfeita-com-a-saude-no-brasil\&catid=3.

CFM. Para 93\% da população, a saúde Brasil é considerada péssima, ruim ou regular. 2015. Disponível em: http://portal.cfm.org.br/index.php?option=com_content\&view=article\&id=25807:2015-10-13-14-55$36 \&$ catid=3.

CFM. Opinião dos brasileiros sobre o atendimento público na área de saúde (2018). 2018.

CHAHAL, H.; KUMARI, N. Consumer Perceived Value and Consumer Loyalty in the Healthcare Sector. Journal of Relationship Marketing, 10, n. 2, p. 15, 2011.

CHAHAL, H.; KUMARI, N. Consumer perceived value -The development of a multiple item scale in hospitals in the Indian context. International Journal of Pharmaceutical and Healthcare Marketing, 6, n. 2, p. $24,2012$.

CHURCHILL, G.; SURPRENANT, C. An investigation into the determinants of costumer satisfaction. Journal of Marketing Research, 19, n. 4, p. 14, 1982.

CHURCHILL, G. A.; SURPRENANT, C. An investigation into the determinants of costumer satisfaction. Journal of Marketing Research, 19, n. 4, p. 14, 1982.

CNI, C. N. D. I.-. Retratados da sociedade brasileira: saúde publica (2011). CNI. Brasília. 2012.

CNI, C. N. D. I.-. Retratados da sociedade brasileira: saúde publica (2018). CNI. Brasília. 2018.

CRONIN, J. J.; BRADY, M. K.; BRAND, R. R.; HIGHTOWER JR., R. et al. A cross-sectional test of the effect and conceptualization of service value. Journal of Services Marketing, 11, n. 6, p. 375-391, 1997.

CRONIN, J. J.; BRADY, M. K.; HULT, G. T. M. Assessing the effects of quality, value, and customer satisfaction on consumer behavioral intentions in service environments. Journal of Retailing, 76, n. 2, p. 26, 2000.

CRONIN, J. J.; TAYLOR, A. S. Measuring service quality: a reexamination and a extension. American Marketing Association, 56, 1992.

CRONIN, J. J.; TAYLOR, S. A. SERVPERF versus SERVQUAL: reconciling performance-based and perceptions-minusexpectations measurement of service quality. Joumal cf Marketing, 58, p. 8, 1994.

CRONIN, J. R. J.; TAYLOR, A. S. Measuring service quality: a reexamination and a extension. American Marketing Association, 56, 1992.

CRUZ, W. B. S.; MELLEIRO, M. M. Análise da satisfação dos usuários de um hospital privado. Revista Escola de Enfermagem da USP, 2007.

DA SILVA, F. J. C. P. Avaliação da qualidade do serviço de saúde: a visão do cliente. Orientador: LAUS, D. A. M. 2014. 130 f. Doctoral - Escola de Enfermagem, Universidade de São Paulo, Ribeirão Preto.

DA SILVA, R. B. Desempenho governamental e apoio à democracia no Brasil. Orientador: MENEGUELLO, R. 2009. (Master) - Departamento de Ciência Política, Universidade Estadual de Campinas, Campinas. Disponível em: http://www.opiniaopublica.ufmg.br/biblioteca/dissertacao_robert.pdf.

DA SILVA, R. B.; SCHLEGEL, R. Panorama e determinantes da satisfação com os serviços públicos do Brasil. Rev. Serviços Públicos, 63, n. 4, p. 22, 2012.

DEVELOPMENT, O. F. E. C. A. OECD Health Data 2001. Paris: Organisation for Economic Cooperation and Development 2001.

DILLON, W. R. Good Science. In: Marketing Research, 1997, 9. 4. 
ESPERIDIÃO, M.; TRAD, L. A. B. Avaliação de satisfação de usuários. Ciência e saúde coletiva [online]. Ciência e saúde coletiva [online]. 10: 10 p. 2005.

ESPERIDIÃO, M. A. O usuário e o julgamento dos serviços de saúde. Orientador: SILVA, L. M. V. D. 2009. 171 f. Doctoral -, Universidade Federal da Bahia, Bahia.

FERNANDES, F. M. B.; RIBEIRO, J. M.; MOREIRA, M. R. Reflexões sobre Avaliação de Políticas de Saúde no Brasil. Cad. Saúde Pública. Rio de Janeiro: Cad. Saúde Pública. 27: 11 p. 2011.

FERREIRA, P. L. Family of Instruments to Evaluate Hospital quality: a pilot test. Coimbra, Portugal: Faculty of Economics 1993.

FERREIRA, P. L.; LUZ, A.; VALENTE, S.; RAPOSO, V. M. et al. Determinantes da satisfação dos utentes dos cuidados primários: 0 caso de Lisboa e Vale do Tejo [Determinants of satisfaction of primary care users: the case of Lisbon and Tagus Valley]. Revista Portuguesa de Saúde Pública, 2, p. 9, 2001.

FERREIRA, P. L.; MENDES, J. Hospital patient satisfaction: a Portuguese experience. European Healthcare Management Association Conference Changing management in healthcare: new missions, conditions \& skills. EHMA, 69, 1997.

FERREIRA, P. L.; RAPOSO, V. M. A governação em saúde e a utilização de indicadores de satisfação [Health governance and the use of satisfaction indicators]. Revista Portuguesa de Clínica Geral. Revista Portuguesa de Clínica Geral. 22: 12 p. 2006.

FERREIRA, P. L.; RAPOSO, V. M.; PISCO, L. A voz dos utilizadores dos cuidados de saúde primários da região de Lisboa e Vale do Tejo, Portugal [The voice of Primary Care patients in the Lisbon and Tagus Valley region of Portugal]. Ciência \& Saúde Coletiva, 22, n. 3, p. 12, 2017.

FONTNOTE, G.; HENKE, L.; CARSON, K.; CARSON, P. P. Techniques for determining importance: Balancing scientific method and subjectivity. Journal of Targeting, Measurement and Analysis for Marketing, 15, p. 11, 2007.

GIESE, J. L.; COTE, J. A. Defining Consumer Satisfaction. Academy of Marketing Science Review, 2000, p. 24, 2000.

GOUVEIA, G. C.; SOUZA, W. V. D.; LUNA, C. F.; SOUZA-JÚNIOR et al. Satisfação dos usuários do sistema de saúde brasileiro: fatores associados e diferenças regionais. Rev. Bras. Epidemiol. 12:15 p. 2009.

GRÖNROOS, C. A service quality model and its marketing implications. European Journal of Marketing, 18, n. 4, p. 9, 1984a.

GRÖNROOS, C. A Service Quality Model and Its Marketing Implications. European Journal of Marketing, 18, n. 4, p. 1, 1984b.

GRÖNROOS, C. Service Quality: the six criteria of good perceived service. 9, n. 3, p. 4, 1988.

GRÖNROOS, C. Service management and marketing: a customer relationship management approach. 2nd ed. New York, USA: 2000. 0-471-72034-8.

GRÖNROOS, R. Value-driven relational marketing: from products to resources and competencies. Journal of Marketing Management, 13, n. 5, p. 13, 1997.

HANSON, R. Determining attribute importance. Quirk's Marketing Research Review. Quirk's Marketing Research Review 1992.

HERCOS, B. V. S.; BEREZOVSKY, A. Qualidade do serviço oftalmológico prestado aos pacientes ambulatoriais, do Sistema Único de Saúde - SUS. In: XV Congresso Norte-Nordeste de Oftalmologia, 2004, Belo Horizonte, Minas Gerais-Brasil.

KANG, G. D.; JEFFREY, J. Service quality dimensions: an examination of Grönroos service quality mode. Managing Service Quality, 14, n. 4, p. 12, 2004. 
KARATEPE, O. M.; YAVAS, U.; BABAKUS, E. Measuring service quality of banks: scale development and validation. Journal of Retailing and Consumer Services, 12, n. 5, p. 373-383, 2005.

KOPALLE, P. K.; LEHMANN, D. R. Strategic management of expectations: The role of disconfirmation sensitivity and perfectionism. Journal of Marketing Research, 38, n. 3, p. 9, 2001.

MACHADO, J. P.; MARTINS, A. C. M.; MARTINS, M. S. Avaliação da qualidade do cuidado hospitalar no Brasil: uma revisão sistemática. Cad. Saúde Pública. Rio de Janeiro: Cad. Saúde Pública. 29: 20 p. 2013.

MANGOLD, W. G.; BABAKUS, E. Adapting the SERVQUAL Scale to Healthcare Environment: an Empirical Assessment. Enhancing Knowledge Development in Marketing, 9, n. 1, p. 2, 1989.

MANO, H.; OLIVER, R. L. Assessing the dimensionality and structure of the consumption experience: Evaluation, feeling, and satisfaction. Journal of Consumer Research, 20, n. 3, p. 17, 1993.

MITTAL, V.; ROSS, W. T. J.; BALDASARE, P. M. The asymmetric impact of negative and positive attribute-level performance on overall satisfaction and repurchase intentions. Journal of Marketing, 62, n. 1, p. 1, 1998.

MOITA, G. F. Avaliação e monitoramento de resultados no planejamento regional do SUS: pactuações, desafios e potencialidades. Orientador: RIBEIRO, J. M. 2019a. 184 f. Master (Mestrado) - Escola Nacional de Saúde Pública Sérgio Arouca, Fundação Oswaldo Cruz (Fiocruz), Rio de Janeiro. Disponível em: https://www.arca.fiocruz.br/simple-search?query=Galba+Freire+Moita.

MOITA, G. F. Avaliação integrativa de performance multidimensional e decisão multicritério: um proxy de painel de indicadores de eficiência, efetividade e qualidade para governança de organizações hospitalares e serviços de saúde no Brasil. Orientador: RAPOSO, V. M. e BARBOSA, A. C. Q. 2019b. 364 f. Doctoral (Doutoramento) Faculdade de Ciências Econômicas - Departamento de Ciências Administrativas, Universidade Federal de Minas Gerais, Belo Horizonte. Disponível em: http://hdl.handle.net/1843/32451.

MOITA, G. F. Avaliação integrativa de performance multidimensional e decisão multicritério: um proxy de painel de indicadores de eficiência, efetividade e qualidade para governação de organizações hospitalares e serviços de saúde no Brasil. Orientador: RAPOSO, V. M. e BARBOSA, A. C. Q. 2019c. 366 f. Doctoral (Doutoramento) Faculdade de Economia, Universidade de Coimbra, Coimbra. Disponível em: http://hdl.handle.net/10316/88714.

MOITA, G. F.; BERNARDO, C. G.; COSTA, J. C.; AZEVEDO, D. A., 2018, Inglês, Lisbon. Business Intelligence application in adaptation of SERVQUAL scale at brazilian health system. 11th IADIS International Conference Information Systems \# IADIS 2018. 77-86. Disponível em: http://www.iadisportal.org/digital-library/iadisinternational-conference-information-systems-is.

MOITA, G. F.; RAPOSO, V. M. R.; BARBOSA, A. C. Q. Quality Saúde - uma adaptação transcultural multicêntrica dos constructos da escala SERVQUAL de satisfação para o SUS, por translação de conhecimento de especialistas e usuários. Rev. Serv. Público, abr/jun, 70, n. 2, p. 40, 2019 a.

MOITA, G. F.; RAPOSO, V. M. R.; BARBOSA, A. C. Q., 2019, Madrid. Reliability and validity analyzes of constructs and dimensions scale of measurement of quality and satisfaction of public health users in Brazil. Actas Gobernando el Futuro:agenda 2030. 20. Gobernanza e Innovaciones Participativas v. Disponível em: https://congresox.gigapp.org/program-schedule.

MOITA, G. F.; RAPOSO, V. M. R.; BARBOSA, A. C. Q. Validação colaborativa de macrodimensões e indicadores-chave para avaliação de performance de serviços de saúde no Brasil. Saúde em Debate, 43, n. 5, p. 232-247, 2019b.

MOITA, G. F.; RAPOSO, V. M. R.; BARBOSA, A. C. Q. A construção de um modelo de avaliação por profissionais e gestores de saúde: validação e consolidação de dimensões e indicadores de performance em serviços e unidades de saúde do SUS. Rev. Serv. Público, jul/set, 70, n. 3, p. 41, 2020.

MURRAY, C. J. L.; FRENK, J. A framework for assessing the performance of health systems Bulletin of the World Health Organization, 78, n. 6, p. 15, 2000. 
OECD. Economic survey of Brazil 2018. Paris. 2018.

OLIVER, R. L. A Cognitive model of the antecedents and consequences of satisfaction decisions. Journal of Marketing Research, 17, n. 4, p. 10, 1980.

OLIVER, R. L. Measurement and evaluation of the satisfaction process in retail settings. Journal of Retailing, $57, \mathrm{n}$. 3, p. 24, 1981a.

OLIVER, R. L. What in costomer satisfaction? Wharton Magazine. Wharton Magazine. 5: 6 p. $1981 \mathrm{~b}$.

OLIVER, R. L. Processing of the satisfaction in consumptions a suggested framework and research propositions. Journal of Consumer Satisfaction, 2, p. 16, 1989.

OLIVER, R. L. A conceptual model of service quality and service satisfaction: compatible goals, different concepts. In: INC, J. P. (Ed.). Advances in services marketing and management: research and practice. Greenwick: JAI Press Inc, 1993a. v. 2, p. 65-85.

OLIVER, R. L. Cognitive, affective, and attribute bases of the satisfaction response. Journal of Consumer Research, 20, p. 13, 1993b.

OLIVER, R. L. Conceptual issues in the structural analyses of consumption emotion, satisfaction, and quality: evidence in a service setting. In: RESEARCH, A. F. C. (Ed.). Advances in consumer research, 1994. v. 21, p. 16-22.

OLIVER, R. L. Varieties of value in the consumption satisfaction response. Advances in Consumer Research, 23, n. 1, p. 5, 1996.

OLIVER, R. L. Satisfaction, a behavioral perspective on the consumer. Irwin/MacGraw-Hill, 1997.

OLIVER, R. L. Satisfaction: a behavioral perspective on the consumer. 2nd ed. New York: Routledge, 2010. 9781315700892.

OLIVER, R. L.; DESARBO, W. S. Response determinants in satisfaction judgments. Journal of Consumer Research, 14, p. 13, 1988a.

OLIVER, R. L.; DESARBO, W. S. Response Determinants in Satisfaction Judgments. \|l Journal of Consumer Research, 14, p. 13, 1988b.

OLIVER, R. L.; LINDA, G. Effects of satisfaction and its antecedents on consumer preference and intention. Advances in Consumer Research, 8, p. 6, 1981.

OLIVER, R. L.; SWAN, J. E. Consumer perceptions of interpersonal equity and satisfaction in transactions: a field survey approach. Journal of Marketing, 53, n. 2, p. 15, 1989.

PARASURAMAN, A.; BERRY, L. L.; ZEITHAML, V. A. A Conceptual model of service quality and its implications for future research. Journal of Marketing, 49, p. 41-50, 1985a.

PARASURAMAN, A.; BERRY, L. L.; ZEITHAML, V. A. A Conceptual Model of Service Quality and its Implications for Future Research. Journal of Marketing, 49, p. 10,1985b.

PARASURAMAN, A.; BERRY, L. L.; ZEITHAML, V. A. A Conceptual Model of Service Quality and its Implications for Future Research. Journal of Marketing, 49, p. 41-50, 1985c.

PARASURAMAN, A.; BERRY, L. L.; ZEITHAML, V. A. SERVQUAL: a multiple-item scale for measuring consumer perceptions of service quality. Joumal of Retailing, 64, p. 29, 1988 a.

PARASURAMAN, A.; BERRY, L. L.; ZEITHAML, V. A. SERVQUAL:A Multiple-Item Scale for Measuring Consumer Perceptions of Service Quality. Joumal of Retailing, 64, p. 29, 1988b.

PARASURAMAN, A.; BERRY, L. L.; ZEITHAML, V. A. Refinement and Reassessment of the SERVQUAL Scale. Journal of Retailing, 67, n. 4, 1991a. 
PARASURAMAN, A.; BERRY, L. L.; ZEITHAML, V. A. Understanding costumer expectation of service. Sloan Management Review, 31, p. 10, 1991b.

PARASURAMAN, A.; BERRY, L. L.; ZEITHAML, V. A. Moving forwar in service quality research: measuring different customer-expectation levels, comparing alternative scales, and examining the perfomance - behavioral intentions link. Working Paper, 1994.

PARASURAMAN, A.; GREWAL, D. Serving customers and consumers effectively in the twenty-first. Academy of Marketing Science. Journal, 28, n. 1, 2000.

PARASURAMAN, A.; ZEITHAML, V.; BERRY, L. Reassessment of Expectations as a Comparison Standard in Measuring Service Quality: Implications for Further Research. Journal of Marketing, 58, p. 14, 1994.

PARASURAMAN, A.; ZEITHAML, V. A.; BERRY, L. L. Reassessment of expectations as a comparison standard in measuring service quality: implications for further research. Journal of Marketing, 58, p. 14, 1994.

PEDRO, S.; FERREIRA, P. L.; MENDES, J. Aplicação de métodos estatísticos na avaliação da satisfação dos utentes com o internamento hospitalar. Tourism \& Management Studies. Tourism \& Management Studies. 6: 15 p. 2010.

PETER, J. P.; CHURCHILL, G. A. Relationships among Research Design Choices and Psychometric Properties of Rating Scales: A Meta-Analysis. Journal of Marketing Research, 23, p. 10, 1986.

RAPOSO, V. Governação hospitalar - uma proposta conceptual e metodológica para o caso português. 2007. Faculdade de Economia, Universidade de Coimbra, Coimbra.

ROSALEM, V. Análise das percepções dos principais atores da cadeia produtiva da saúde sobre a qualidade dos serviços prestados por hospitais no Estado de Goiás - Brasil. 2013. Doctoral -, Escola de Administração de Empresas de São Paulo, São Paulo.

RUST, R. T.; OLIVER, R. L. Service quality: insights and implications from the frontier service quality. In: SAGE (Ed.). New Directions in Theory and Practice. Thousand Oaks, CA, 1994.

SHEMWELL, D. J.; YAVAS, U. Measuring Service Quality in Hospitals: Scale Development and Managerial Applications. Journal of Marketing Theory and Practice, 7, n. 3, p. 11, 1999.

SHEMWELL, D. J.; YAVAS, U.; BILGIN, Z. Customer-service provider relationships: an empirical test of a model of service quality, satisfaction and relationship-oriented outcomes. International Journal of Service Industry Management, 9, n. 2, p. 14, 1998.

SOUZA-JÚNIOR, P. R. B. D.; FREITAS, M. P. S. D.; ANTONACI, G. D. A.; SZWARCWALD, C. L. Desenho da amostra da Pesquisa Nacional de Saúde 2013. Epidemiologia e Serviços de Saúde, 24, n. 2, p. 207-216, 2015.

SURPRENANT, C. F.; SOLOMON, M. R. Predictability and Personalization in the Service Encounter. Journal of Marketing, 51, n. 2, p. 1, 1987.

SWAN, J. E.; TRAWICK, F. I. Satisfaction related to predictive vs. desired expectations. In: Refining Concepts and Measures of Consumer Satisfaction and Complaining Behavior. Bloomington: University of Indiana School of Business, 1980. p. 7-12.

SWAN, J. E.; TRAWICK, F. I. Disconfirmation of expectations and satisfaction with a retail service. Journal of Retailing, 57, n. 3, p. 19, 1981a.

SWAN, J. E.; TRAWICK, F. I. Disconfirmation of expectations and satisfaction with a retail service. Journal of Retailing, 57, n. 3, p. 19, 1981b.

SZWARCWALD, C. L.; MALTA, D. C.; PEREIRA, C. A.; VIEIRA, M. L. F. P. et al. Pesquisa Nacional de Saúde no Brasil: concepção e metodologia de aplicação Ciên. \& Saúde Coletiva, 19, n. 2, p. 10, 2014.

SZYMANSKI, D. M.; HENARD, D. H. Customer satisfaction: A meta-analysis of the empirical evidence. Academy of Marketing Science. Journal, 29, n. 1, p. 1, 2001. 
TAYLOR, S. A.; CRONIN, J. J. Modeling patient satisfaction and service quality. Spring, 14, n. 1, p. 12, 1994.

TSE, D. K.; WILTON, P. C. Models of consumer satisfaction: an extension. Journal of Marketing Research, 25, p. 9, 1988 a.

TSE, D. K.; WILTON, P. C. Models of Consumer Satisfaction: Na Extension. Journal of Marketing Research, 25, p. 9, 1988 b.

UNDP. Handbook on Planning, Monitoring and Evaluation for Development Results. 2009.

UNIT, O. H. P. Health at a Glance. Paris: Organisation for Economic Co-operation and Development 2001.

VINAGRE, M. H. A satisfação de utentes de serviços públicos de saúde: preditores e mediadores. 2008. Doctoral -, Instituto Superior de Ciências do Trabalho e da Empresa-ISCTE, Portugal: Lisboa.

VOLPATO, L. F. Utilização de uma ferramenta para análise da qualidade nos serviços públicos de saúde. Orientador: MENEGHIM, M. D. C. 2014. 112 f. Doctoral - Faculdade de odontologia de Piracicaba, Universidade estadual de campinas, Piracicaba

WESTBROOK, K. W.; BABAKUS, E.; GRANT, C. C. Measuring patient-perceived hospital service quality: validity and managerial usefulness of HCAHPS scales. Health Marketing Quarterly, 31, n. 2, p. 18, 2014.

WESTBROOK, K. W.; GRANT, C. C.; RAFALSKI, E.; BABAKUS, E. Patient-family centered care: measuring perceived service quality following a critical care services experience. Journal of Health Management, 17, n. 3, p. 12, 2015.

WESTBROOK, R. A. A rating scale for measuring product/service satisfaction. Journal of marketing, 44, n. 4, p. 5, 1980.

WESTBROOK, R. A. Product/consumption based affective responses and postpurchase processes. Journal of Marketing Research, 24, p. 13, 1987.

WESTBROOK, R. A.; NEWMAN, J. W. An analysis of dissatisfies shoppers for major household appliances. Journal of Marketing Research, 15, p. 11, 1978.

WESTBROOK, R. A.; NEWMAN, J. W.; TAYLOR, J. R. Satisfaction/dissatisfaction in the purchase decision process: are consumers really as dissatisfied as many studies claim? Journal of Marketing, 42, n. 4, p. 7, 1978.

WESTBROOK, R. A.; NEWMAN, J. W.; TAYLOR, J. R. Satisfaction/Dissatisfaction in the Purchase Decision Process: Are consumers really as dissatisfied as many studies claim? Journal of Marketing, 42, n. 4, p. 7, 1978.

WESTBROOK, R. A.; OLIVER, R. L. Developing Better Measures of Consumer Satisfaction: Some Preliminary Results. In: RESEARCH, A. F. C. (Ed.). Advances in Consumer Research. Ann Arbor, MI, 1981. v. 8, p. 94-99.

WESTBROOK, R. A.; OLIVER, R. L. The dimensionality of consumption emotion patterns and consumer satisfaction. Journal of Consumer Research, 18, n. 1, p. 8, 1991.

WESTBROOK, R. A.; REILLY, M. D. Value-percept disparity: an alternative to the disconfirmation of expectations theory of consumer satisfaction. Advances in Consumer Research, 10, n. 1, p. 6, 1983.

WHO. The World Health Report 2000. Health Systems: Improving Performance ORGANIZATION, W. H. Geneva: World Health Organization 2000.

YI, Y. A Critical Review of Consumer Satisfaction. In: ASSOCIATION, A. M. (Ed.). Review of Marketing. Chicago: American Marketing Association, 1990. p. 68-123.

ZEITHAML, V. A.; BERRY, L. L.; PARASURAMAN, A. The nature and determinants of customer expectations of service. Academy of Marketing Science. Journal, 21, n. 1, p. 1, 1993 a.

ZEITHAML, V. A.; BERRY, L. L.; PARASURAMAN, A. The nature and determinants of customer expectations of service. Academy of Marketing Science, 21, n. 1, p. 1, 1993b.

ZEITHAML, V. A.; PARASURAMAN, A.; BERRY, L. L. Delivering quality service: balancing customer perceptions and expectations. The Free Press, New York, 1990. 


\title{
O PROCESSO DE ADESÃO AO PROGRAMA DA QUALIDADE NO SERVIÇO PÚBLICO (PQSP) E A QUALIDADE NO ATENDIMENTO EM SAÚDE, EM FUNÇÃO DA EXCELÊNCIA
}

\author{
Priscila Marinho da Silva \\ Faculdade dos Guararapes
}

\section{RESUMO}

Esta pesquisa aborda a gestão da qualidade em organizações de saúde tendo por base o Programa da Qualidade no Serviço Público - PQSP, onde através de uma pesquisa de campo aplicada em uma unidade de saúde pública municipal direcionada às gestoras, aos colaboradores e clientes pôde ser percebido se a mesma exerce a qualidade em termos de serviços oferecidos à população, assim como os entraves encontrados pela administração e funcionários, permitindo a partir dessa análise perceber que apesar dos usuários se mostrarem satisfeitos em diversos aspectos o mesmo não ocorre por quem presta o serviço, demonstrando, porém, que tal fator não afeta diretamente os pacientes atendidos, embora deva ser um ponto a ser levado em questão pela gestão da unidade, devendo através do trabalho em equipe satisfazer todas as partes envolvidas no processo. A pesquisa também permitiu discorrer sobre os fatores que dificultam a implementação de programas de qualidade nas organizações, como também os meios que levam a melhoria na prestação de serviços em saúde. A gestão da unidade poderá através da análise deste trabalho, direcionar ações no intuito de diminuir o índice de insatisfação dos colaboradores e clientes, melhorando com isso, os serviços prestados.

\section{Palavras-chave:}

Qualidade em Saúde; Gestão Pública; Prestação de Serviços.

\begin{abstract}
This research approaches the quality management in health organizations based on the Program for Quality in Public Service - PQPS, in which, by means of a field research implemented in a local public health unit focused on management companies, employees and customers could be found out if it carries on quality in terms of services provided to the population, as well as the obstacles faced by management and employees, allowing to realize from this analysis that although the users were satisfied in several ways this is not true for those who provide the service, showing, however, that this factor does not directly affect the treated patients, it should be though a point to be brought into question by the unit management, and through teamwork, it should satisfy all of the involved parties. The survey also enabled to discuss the factors which disrupt the
\end{abstract}

implementation of programs for quality in organizations, as well as the means leading to improvement in health service provision. The unit management, by analyzing this work, may direct actions so as to reduce the rate of dissatisfaction among employees and customers, thus improving the services provided.

\section{Keywords:}

Quality in Health; Public Management; Service Provision. 


\section{INTRODUÇÃO}

A implementação de programas de qualidade nas organizações públicas geralmente vem acrescido de obstáculos que devem ser superados por meio do trabalho em equipe, fortalecendo dessa maneira os laços entre os integrantes da equipe de trabalho e alcançando os objetivos propostos pela gestão.

A pesquisa teve por base o estudo de uma unidade pública de saúde municipal, onde a autora exerce suas atividades laborais, onde foi possível a análise desta organização, através da aplicação de questionários direcionados às partes envolvidas.

Assim sendo, esta investigação analisa através da realização de uma pesquisa de campo, a visão de duas gestões, visto que no decorrer da elaboração do trabalho e consequentemente da pesquisa houve uma mudança na gestão da unidade, além disso, foi analisada também a opinião dos colaboradores da unidade assim como dos clientes/pacientes/usuários dos serviços a serem prestados.

Essa pesquisa demonstra através de seus resultados a necessidade de conscientização por parte das organizações públicas a prestarem um atendimento à população com excelência e, com isso, faz com que o público seja seu principal beneficiado, excluindo-se a impressão da sociedade de que o órgão público não presta bons atendimentos.

\section{REFERENCIALTEÓRICO}

\subsection{O PROCESSO DE ADESÃO AO PROGRAMA DA QUALIDADE NO SERVIÇO PÚBLICO (PQSP)}

De acordo com Brasil (2002), "Podem aderir ao Programa da Qualidade no Serviço Público (doravante PQSP) às organizações públicas brasileiras, ou suas unidades, dos níveis federal, estadual e municipal, dos Poderes Executivo, Legislativo e Judiciário". Ou seja, abrange todos os tipos de organizações públicas existentes.

Para formalizar a adesão ao Programa é preciso que a organização representada pelo dirigente maior assuma um compromisso formal e publicamente enviando para a Gerência Executiva do Programa o Termo de Adesão disponível no endereço eletrônico ${ }^{1}$.

Ainda conforme Brasil (2002), "A adesão não deve se restringir ao ato formal e burocrático de assinar um termo e montar um comitê", alertando ainda que, "Se a direção não está disposta a aceitar o desafio da transformação preconizado pelo Programa é melhor não oficializar a adesão". Para que a adesão obtenha sucesso, é necessário que o ato formal seja acompanhado de um processo de informação e sensibilização em que estejam envolvidas a alta administração, em conjunto com parte

\footnotetext{
1 http://qualidade.planejamento.gov.br
} 
do corpo gerencial e dos chamados formadores de opinião, que são aqueles que independente do cargo que exercem, têm o poder de influenciar as pessoas da organização.

Segundo Brasil (2002), os compromissos assumidos pela organização pública ao aderirem ao PQSP, são:

- $\quad$ Orientar a prática gerencial pelos Princípios da Excelência em Gestão Pública, preconizados pelo Programa;

- Implementar ciclos contínuos de avaliação e melhoria da gestão com base no Modelo de Excelência em Gestão Pública;

- Indicar dois servidores para integrarem a Rede Nacional de Consultores do PQSP;

- Estabelecer e divulgar padrões de qualidade de atendimento aos usuários dos serviços da organização;

- Avaliar periodicamente a satisfação dos usuários, observando os parâmetros de pesquisa fixados pelo Programa;

- Adotar a prática da colaboração institucional, trocando experiências com outras organizações públicas;

- Dar ampla divulgação à participação da organização no Programa, utilizando sua logomarca no material técnico e de divulgação.

É importante ressaltar que o fator determinante da continuidade ou não da organização pública no Programa é a manutenção de ciclos contínuos de avaliação e melhoria da gestão, sendo necessário para tanto, que a organização esteja engajada no propósito de oferecer serviços/produtos com qualidade aos seus usuários, estando atentos às suas necessidades, ouvindo as reclamações, sugestões e elogios, no sentido de corrigir as falhas e/ou manter as práticas que tiveram resultados satisfatórios.

É preciso que cada organização organize a coordenação do Programa da melhor forma possível, com a constituição de um 'Comitê Gestor', pois é essencial para liderar as ações a serem implementadas pela organização, além disso, é necessário a participação de integrantes da alta administração nesse Comitê, que de acordo com Brasil (2002), "[...] se comuniquem com facilidade com as diversas áreas da organização e que tenham capacidade para atuar como mobilizadores e facilitadores". Quando em alguns casos, a condução estratégica do Programa é assumida pela alta administração, um comitê não é constituído, visto as ações a serem integradas entrarem tanto na sua pauta, como na reunião de seus colegiados.

\subsection{FATORES QUE DIFICULTAM A IMPLEMENTAÇÃO DE PROGRAMAS DE QUALIDADE NAS ORGANIZAÇÕES}

Inúmeros são os fatores que dificultam a implantação de programas de gestão de qualidade nas organizações, entre eles alguns se relacionam à estrutura organizacional, ao processo produtivo, como também à política de pessoal e o grau de abertura da empresa para as questões relacionadas à qualidade. Os mais importantes de acordo com Gil (2007, p.268) são: 
- Inexistência de canais de comunicação para expressar as sugestões e reivindicações dos empregados;

- Despreocupação com as expectativas dos clientes;

- Pouco incentivo à iniciativa e à inovação;

- Dentre outros.

Portanto, é perceptível que grande parte dos obstáculos à implantação aos programas da qualidade estão relacionados às pessoas, o que faz com que as organizações incentivem o capital humano na busca constante pela qualidade.

\subsection{QUALIDADE NO ATENDIMENTO EM SAÚDE}

O conceito de qualidade no setor de saúde de acordo com Rebelo (1995), "Sempre esteve relacionado de modo implícito com os cuidados médicos e as ações dos profissionais de saúde", visto se tratar de uma atividade que lida com a saúde do indivíduo e que por isso mesmo, "Não pode enveredar pelo caminho do descaso, do amadorismo ou da aventura". Dessa forma conclui-se que, para o atendimento das enfermidades que acometem as pessoas, o mesmo deve ser prestado por profissionais qualificados/capacitados para exercer o cargo e comprometidas em solucionar da melhor maneira possível os problemas dos que chegam diariamente às unidades de saúde.

O autor acima ainda ressalta que as pessoas percebem quando não estão bem de saúde e que quando isso ocorre há uma perturbação, interferindo diretamente no seu estado de satisfação e bem-estar e que por esta razão, a saúde é uma condição necessária ao ser humano e se encontra em, "Condição oposta à da doença que leva à disfunção e à incapacidade". Tudo isso demonstra que uma pessoa doente é uma pessoa fragilizada, devendo a mesma ser acolhida de forma humanizada e com qualidade, devendo essa se estender a todos os setores envolvidos no atendimento à promoção da saúde. E ainda caracteriza que "Quando se adoece há sempre a procura angustiada de uma cura rápida e definitiva para a moléstia”, portanto, o doente tem pressa, e a procura para o tratamento de saúde nem sempre é fácil para ele. Por isso, a necessidade de profissionais sensíveis para o atendimento direto ao doente, no sentido de ser tratado de modo cortês.

A propósito o autor comunica que:

Ao procurar um profissional ou instituição de saúde, o indivíduo anseia encontrar pessoas tecnicamente capacitadas e sensiveis no trato interpessoal. Se não as encontra procura outra alternativa ou, simplesmente, abandona o tratamento. Se obtém sucesso costuma divulgar o fato aos amigos.

Dessa forma, o profissional que atende diretamente os pacientes é o principal responsável para que os usuários retornem à unidade de saúde e/ou permaneçam no tratamento. Quando se trata de 
instituições privadas o cliente critica o atendimento quando não é bem prestado e ele é ressarcido de alguma forma, podendo retornar ou não, e quem é prejudicado é a própria instituição que perderá a credibilidade junto à clientela, podendo perder clientes em potenciais pela propaganda negativa gerada por aquele que saiu insatisfeito. Quando esse mesmo caso ocorre em organizações públicas, a imagem da mesma fica prejudicada e, além disso, a imagem do serviço público e na maioria dos casos o paciente retorna, visto não ter outra alternativa.

Entre as diferenças existentes entre os setores público e privado, no que concerne Brasil (2002), destacam-se:

A finalidade principal das atividades de caráter privado é o lucro que lhe dá capacidade de sobrevivência em um ambiente de alta competitividade; por sua vez, a principal finalidade das atividades públicas é prestar serviços à sociedade;

- A preocupação em satisfazer o cliente no setor privado é baseada no interesse, enquanto no setor público essa preocupação tem que ser alicerçada no dever;

- $\quad$ Cliente atendido, no setor privado, remunera diretamente a organização, pagando pelo serviço recebido ou pelo produto adquirido; no setor público, o cliente atendido, paga indiretamente, pela via do imposto, sem qualquer simetria entre a quantidade e a qualidade do serviço recebido e o valor do tributo que recolhe;

- As políticas voltadas para a Qualidade no setor privado referem-se a metas de competitividade para obtenção, manutenção e expansão de mercado, enquanto no setor público, a meta é a busca da excelência no atendimento a todos os cidadãos, ao menor custo possível;

- As diferentes contingências a que estão submetidos os dois setores como, por exemplo, limites de autonomia estabelecidos pela legislação e o perfil da clientela.

Ainda de acordo com Brasil (2002), a adoção da qualidade como instrumento de modernização da administração pública brasileira deverá levar em conta, simultaneamente, a sua dimensão formal que se refere à competência para produzir e aplicar métodos, técnicas e ferramentas - e a sua dimensão política - que se refere à competência para projetar e realizar organizações públicas que atendam às necessidades dos cidadãos. A gestão pela Qualidade instrumentaliza o alcance da dimensão política em sua expressão mais ampla: a cidadania.

O PQSP percebe a importância de se criar uma 'tecnologia de gestão pública' que seja compatível com os padrões internacionais de qualidade e desempenho de maneira que não anule as características essenciais definidoras do setor público brasileiro e que o distinguem dos setores privados e nãogovernamentais.

Os parâmetros internacionais impactam e qualificam a gestão pública por meio da parceria com empresas e técnicos do setor privado, por outro lado, a eficácia desses parâmetros no espaço público, tanto para estabelecer uma tecnologia de gestão pública, como para torná-la padrão de normalidade gerencial para a maioria das organizações depende essencialmente da formação de uma rede de servidores públicos preparados para conceber, adequar e difundir essa tecnologia que pode ser universal, mas que deve ser, sob qualquer pretexto, necessariamente pública (BRASIL, 2002). Dessa 
maneira se percebe que a tecnologia e parâmetros internacionais e a parceria com o setor privado é fator que integra as diretrizes do Programa, mas que os funcionários públicos precisam ser preparados para atuar em conjunto com essa tecnologia e padrões, tornando-a universal e padronizada sem deixar de ser pública. Ou seja, as tecnologias e padrões existentes na rede privada podem e devem fazer parte integrante do setor público e é esse um fator que determina a qualidade no setor público.

\subsubsection{O que são atendimentos básicos e especializados em saúde}

De acordo com a Cartilha Entendendo o SUS (Brasil, 2006), atendimentos básicos em saúde ou rede de Atenção Básica à Saúde pode ser descrita como:

Atenção Básica: é preferencialmente a "porta de entrada" do sistema de saúde, onde a população tem acesso a especialidades básicas como: clínica médica (clínica geral), pediatria, obstetrícia e ginecologia. Estudos demonstram que a atenção básica é capaz de resolver cerca de $80 \%$ das necessidades e problemas de saúde.

Ainda segundo a Cartilha, a porta de entrada do sistema de saúde deve ser preferencialmente a atenção básica (postos de saúde, centros de saúde, unidades de Saúde da Família, etc.). A partir desse primeiro atendimento, o cidadão será encaminhado para os outros serviços de maior complexidade da saúde pública (hospitais e clínicas especializadas).

Os atendimentos especializados em saúde, como define a Cartilha Entendendo o SUS (Brasil, 2006) podem ser subdivididos em basicamente dois tipos:

Atenção de Média Complexidade: objetiva atender os principais agravos de saúde da população, com procedimentos e atendimentos especializados. São serviços como consultas hospitalares e ambulatoriais, exames e alguns procedimentos cirúrgicos. É constituída por procedimentos ambulatoriais e hospitalares situados entre a atenção básica e alta complexidade.

Atenção de Alta Complexidade: são os procedimentos que envolvem alta tecnologia e/ou alto custo. São exemplos de procedimentos de alta complexidade: traumatoortopedia, cardiologia, terapia renal substitutiva e oncologia. As principais áreas estão organizadas em redes, como as de cirurgias cardíacas e de atenção oncológica.

Cabe à direção municipal do SUS a gestão da rede de serviços em seu território, estabelecendo parcerias com municípios vizinhos para garantir o atendimento necessário à sua população. Com isso, o acesso aos serviços de saúde é uma preocupação da Alta Administração Pública, que garante que todos os níveis hierárquicos (Município, Estado, União, ONGs e iniciativa privada) estejam integrados de modo a sanar os problemas de saúde da população de forma integral. O PQSP é uma maneira de o Governo Federal mobilizar e orientar tanto os dirigentes quanto os servidores para o exercício de um modelo empreendedor de administração pública capaz de prestar serviços de maior qualidade a um menor custo, atendendo desta forma, aos interesses da sociedade.

Faz parte do Governo Federal uma estrutura bem desenvolvida capaz de solucionar todos os problemas de saúde da população, assim como a garantia ao acesso a tais serviços e o PQSP permite garantir que esses serviços sejam oferecidos com qualidade, visando à equidade de atendimento nas redes públicas e privadas. 


\subsubsection{Meios que proporcionam a melhoria da qualidade na prestação de serviços nas organizações de saúde}

Com o intento de garantir a melhoria contínua das atividades produtivas, a gestão da qualidade tem utilizado estratégias para organizar os processos e otimizar o seu funcionamento. Em se tratando de serviços que tem por principais características a intangibilidade e a interação do cliente no processo produtivo, podemos citar como uma das estratégias a utilização do programa da qualidade denominado 5S, pelo entendimento é necessário o investimento em melhoria contínua nas pessoas, pois há o entendimento de que melhorando o desempenho delas se estará melhorando o desempenho das empresas.

O programa foi desenvolvido na década de 50 no Japão e seu nome tem relação com cinco palavras iniciadas por S em japonês que são: seiri (utilização), seiton (ordenação), seisou (limpeza), seiketsu (saúde) e shitsuke (autodisciplina). A ideia do programa é o investimento de mudanças de hábitos e pensamentos, por essa razão adotou-se a palavra "senso" para expressar esses termos genericamente. Para Paladini (2008, p.256) “A ideia é que é necessário "sentir" cada elemento e, daí, definir a necessidade de mudar atitudes e concepções". A percepção é a de que as próprias pessoas devem começar a organizar suas atividades e locais de trabalho de modo a contribuir de forma mais relevante para as empresas.

A descrição de cada senso pode ser definido segundo Paladini (2008, p.256) como:

- Senso de utilização: envolve organização, arrumação ou seleção. Refere-se à melhor utilização dos recursos da organização, evitando excessos, desperdícios ou emprego inadequado;

- Senso de ordenação: está associado à arrumação, racionalização e sistematização. Referese à organização física da empresa, com a definição de processos de alocação (layouts) e intangíveis (informações);

- Senso de limpeza: inclui higiene, asseio e padronização. Refere-se à conservação de ambientes de trabalho;

- Senso de saúde: envolve o bem-estar das pessoas e sua segurança. Refere-se à conservação da saúde dos recursos humanos da organização;

- Senso de autodisciplina: abrange educação e comprometimento. Refere-se à definição e à manutenção de valores (em geral, éticos ou morais, de caráter individual ou coletivo) e à atenção permanente a eles.

Todos os elementos do programa relacionam-se intimamente com os princípios e métodos da gestão da qualidade. Princípios em relação à ênfase na produtividade e a busca pela eliminação de desperdícios, métodos em relação ao envolvimento dos recursos humanos, com o estabelecimento de estratégias direcionadas ao desenvolvimento integral das pessoas. Por ser de simples aplicação e obtenção de resultados práticos, visíveis e valiosos, o torna uma importante estratégia aplicada pelas empresas, podendo também ser utilizadas em organizações públicas. 
As transformações sociais ocorridas nas últimas décadas também desencadearam mudanças nas relações de trabalho. Com relação à qualificação profissional, o conceito de competência foi expandido e atualmente ser competente não se restringe apenas a demonstrar aptidão técnica, mas ter autonomia para solucionar problemas, assumir responsabilidades e disposição para trabalhar em equipe. Sendo essas competências indispensáveis para o profissional se manter no mercado de trabalho. No setor público o envolvimento dessas habilidades, que são técnica, pessoal, social e participativa levam, a construção de uma melhoria na qualidade dos serviços prestados à população.

No que se refere às relações de trabalho, hoje em dia também é imprescindível que o profissional saiba manter relações interpessoais com os colegas, com os profissionais de todos os setores da empresa e os superiores hierárquicos (ZUANETTI et al, 2001, p.36). Dentro desta perspectiva, podese dizer que é necessário saber conduzir-se dentro da empresa, sabendo relacionar-se com todos os níveis hierárquicos. Saber relacionar-se com as pessoas interfere diretamente na qualidade de vida dos indivíduos em todos os aspectos: pessoal e profissional.

A busca pela qualidade nas organizações também exige profissionais abertos às mudanças e inovações, devendo estar interiorizado em cada um deles a predisposição para aprender coisas novas e a percepção de que jamais sabe o suficiente. Para que isso ocorra nas instituições públicas é preciso que haja a conscientização de todos os servidores, como também o apoio da liderança e da alta administração, com a realização e investimento em cursos de capacitação profissional e tecnologia de ponta.

Na prestação de serviços não há espaço para individualismos e exige de cada um a disposição interior para o trabalho em equipe, capacidade para mediar discussões e desenvolver trabalhos com grupos multidisciplinares, compostos por profissionais de diferentes formações e perfis, promovendo a integração da equipe de trabalho e possibilitando o intercâmbio de funções, assim como a uniformização das diversas linguagens organizacionais.

É necessário, no entanto, que os profissionais se identifiquem com os objetivos da empresa e estejam satisfeitos em desempenhar suas funções para que haja a composição de uma equipe de trabalho. Estando esses dois fatores em convergência é possível aumentar a produtividade e a qualidade dos serviços prestados, pois todos estarão empenhados tanto no sucesso da prestação dos serviços, como na satisfação dos clientes. Para tanto é preciso uma mudança de paradigmas no cenário que engloba o setor público brasileiro, no sentido de oferecer não só produtos/serviços com qualidade aos seus cidadãos, como também promover o incentivo do servidor público neste aspecto. E O PQSP demonstra esse interesse como também permite a sua realização, tendo como incentivo o reconhecimento pelo bom desempenho que é feito através das premiações e certificações.

Para se trabalhar em equipe é preciso de acordo com Zuanetti et al (2001, p.43): discutir exclusivamente ideias; buscar um diálogo competente; não temer o conflito; saber ceder; discordar construtivamente; construir ideias.

Dessa forma pode-se concluir que, o trabalho em equipe é a busca permanente pela integração entre seus participantes na condução dos objetivos da empresa.

Ainda segundo o autor, pode-se identificar as fases do trabalho em equipe: abordagem; conversa; superação de objeções; acordo; reabordagem.

Todas essas fases levam a crença de que para que uma equipe de trabalho alcance os objetivos propostos, é necessário que haja debates e acordos, com isso gerará na empresa os resultados 
esperados, visto ter tido o diálogo anterior e o compromisso assumido por cada um de seus integrantes.

Como em toda equipe de trabalho existem as relações de poder. Ter poder é ser capaz de influenciar e provocar mudanças no comportamento ou atitudes dos outros e não exercer a força, ordenar, dar instruções ou oprimir. Pode-se dizer que existem pelo menos dois tipos de poder nas organizações: o institucional (ou legítimo) e o de influência.

O poder institucional ou da autoridade formal: são exercidos de acordo com a posição que as pessoas ocupam na empresa.

o poder de influência: independe do cargo formal exercido dentro da empresa, envolvendo sentimentos como admiração, aceitação e prestígio pela competência, tendo por base a crença de que, segundo Zuanetti et al (2001, p.46) “Quem influencia tem alguma competência relevante ou um conhecimento especial que o influenciado não possui".

O autor ainda define que "É com base no poder institucional que alguém assume uma gerência, [...] mas é o poder de influência que vai fazer desse chefe um verdadeiro líder". Liderança implica não apenas fazer com que os subordinados cumpram suas atribuições, mas também, fazê-los sentir parte integrante da equipe. Assim, liderança é motivá-los, tirar dúvidas, esclarecer e sugerir, gerando por consequência, o respeito e a admiração deles.

Vale salientar que para que todo o trabalho em equipe gere êxito é preciso a abertura ao diálogo por parte da gestão e a harmonia por parte de todos os envolvidos.

Outro aspecto importante é a valorização do profissional, onde é importante nas organizações a criação de um programa contínuo de desenvolvimento de pessoal, com o intuito de estimular e motivar os profissionais, pois cada componente da equipe de trabalho necessita ter provas concretas de que desempenha um papel importante dentro da empresa, se creem no inverso dificilmente se conseguirá o apoio necessário para o alcance dos objetivos organizacionais. É importante que todos estejam envolvidos emocionalmente com o seu trabalho e a percepção intrínseca de que se estará ganhando com o sucesso da empresa.

"Pagar melhores salários é apenas um dos caminhos para se reconhecer o trabalho de profissionais" (ZUANETTI et al, 2001, p.46). Existem outras formas de reconhecimento como elogios e benefícios oferecidos pela empresa como: cursos de especialização, participação em congressos, participação nos lucros e abonos salariais, etc. No setor público, a aplicação de boa parte desses recursos é um desafio, que deve ser assumido pela liderança e pela alta administração para que ocorram mudanças profundas na qualidade dos serviços prestados, pois se deve ter em mente que a reação é encadeada. Se o servidor está satisfeito com o seu trabalho isso reflete diretamente no trato com o cliente - que deve ser entendido tanto no setor privado quanto no público como o bem mais importante da empresa e por isso mesmo deve ser bem tratado. 


\section{METODOLOGIA}

Este trabalho é uma pesquisa de campo, e, como tal, busca conseguir informações e/ou conhecimentos acerca da qualidade dos serviços prestados na Policlínica Cônego Pedro de Souza Leão. A intenção é descobrir novas formas de se gerenciar a qualidade em prestação de serviços na área de saúde, com o intuito de oferecer à população serviços de forma qualitativa, satisfazendo com isso todas as partes envolvidas no processo.

O objetivo deste estudo foi analisar e mensurar o nível de satisfação dos clientes internos e externos, assim como ter uma visão dos entraves encontrados pelas duas gestões, tendo por base o PQSP, sendo possível desta forma, servir como ponto de partida, para que a alta administração municipal tenha interesse em aderir ao Programa, elevando deste modo a qualidade dos serviços oferecidos à população e melhorar a qualidade de vida e profissional de seus servidores.

Segundo Andrade (2006, p.129) “Metodologia é o conjunto de métodos ou caminhos que são percorridos na busca do conhecimento".

Para tanto, a pesquisa desenvolvida teve como principal fundamento, através da investigação metodológica, verificar se a qualidade no atendimento ao público está sendo exercida pela organização investigada, fazendo uso quanto aos fins do método exploratório e comparativo para formação deste conceito.

"A pesquisa exploratória não requer a elaboração de hipóteses a serem testadas no trabalho, restringindo-se a definir objetivos e buscar mais informações sobre determinado assunto de estudo" (CERVO; BERVIAN; DA SILVA, 2007, p.63).

O universo da pesquisa foi direcionada às gestoras, colaboradores e clientes de uma unidade de saúde pública municipal localizada no bairro de Cavaleiro, com o intuito de afirmar ou confrontar o embasamento teórico referente à pesquisa exploratória, contendo três questionários aplicados a duas gestoras, cinquenta e quatro colaboradores e cento e nove clientes.

A pesquisa de campo foi realizada na unidade de saúde pública municipal, denominada Policlínica Cônego Pedro de Souza Leão, localizada no bairro de Cavaleiro, S/N, no município de Jaboatão dos Guararapes-PE, no período de 13 de outubro de 2010 a 12 de novembro de 2010, onde foram analisadas as opiniões da gestão atual da unidade, como também da pretérita, visto que no decorrer da pesquisa houve mudança de gestão na unidade pesquisada e o objetivo foi realizar uma análise comparativa das visões das duas gestoras, no intuito de encontrar convergências ou não em algumas questões, além disso, foram abordadas também as opiniões dos colaboradores e clientes.

Para a pesquisa tanto das gestoras, quanto dos colaboradores foi elaborado um questionário com perguntas objetivas e para os clientes/pacientes/usuários um questionário com perguntas também objetivas, portanto, entende-se que a amostragem é satisfatória visto que em relação aos 
colaboradores foi conseguida a coleta de mais de $50 \%+1$, e em relação aos clientes foi feita uma estimativa da demanda diária no período da manhã, por ser essa a maior quantidade da atuação dos profissionais da unidade e consequentemente maior número de pacientes atendidos e esse quantitativo esperado foi alcançado.

\section{ANÁLISE E DISCUSSÃO DE DADOS}

\subsection{Resultados obtidos com as gestões atual e pretérita da unidade}

A unidade de saúde em que foi realizada a pesquisa de campo, localizada no bairro de Cavaleiro, se enquadra quanto à ordem de grandeza, como de atenção de média complexidade, ou seja, é de médio porte. As unidades que integram essa rede são de extrema relevância quanto ao setor de atuação, visto que contribuem para a diminuição do fluxo nos Hospitais e Unidades de Alta Complexidade, locais esses, onde devem ser atendidos apenas os casos que não podem ser resolvidos nas Unidades de Atenção Básica e Média Complexidade, visto não ter essas a estrutura necessária, nem a tecnologia adequada para resolver tais casos.

A pesquisa de campo foi aplicada a duas gestoras uma que atuou durante um período na unidade e a outra que gere atualmente, portanto as duas são mulheres, demonstrando que cada vez mais existe a atuação do sexo feminino em cargos de gestão, sendo essa a primeira questão do questionário.

A seguir a segunda questão que foi subdivida em três etapas e trata-se a respeito da iniciativa do colaborador para contribuir/sugerir novas ideias para melhoria da qualidade no atendimento ao cliente_onde na primeira parte foi perguntado sobre a disponibilidade para pôr em prática quando é da competência da própria gestão, onde o resultado foi:

Gráfico 1: Disponibilidade da gestão em pôr em prática sugestões dos colaboradores para melhoria do atendimento quando é de sua competência

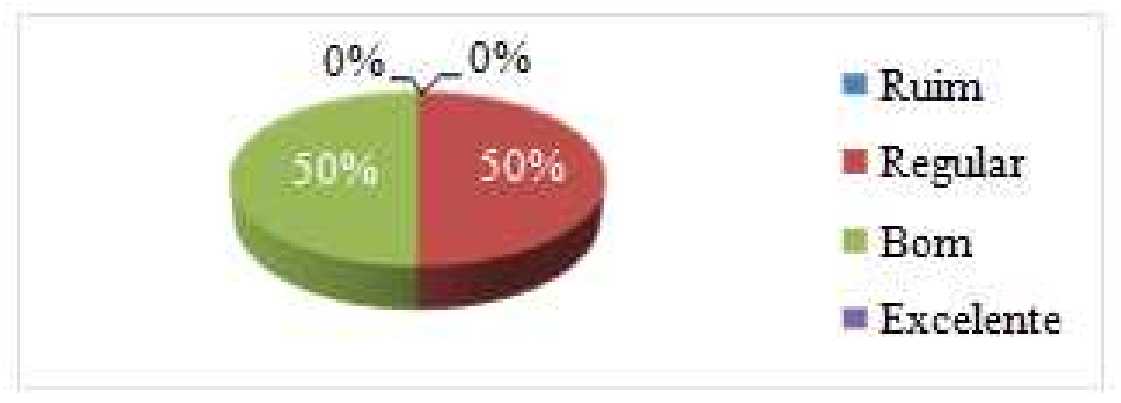

Fonte: autoria própria, dados coletados na pesquisa de campo, 2010

Pode ser observada a cisão de opiniões acerca do questionamento realizado, onde uma considera regular e a outra bom a disponibilidade para pôr em prática as ideias dos colaboradores para a construção da melhoria do atendimento, quando for de sua competência. Podendo ocorrer essa divergência por diversos fatores, que não podem ser aqui enumerados, visto não fazer parte da realidade laboral da pesquisadora sobre tais informações. A segunda parte trata-se sobre a 


\section{disponibilidade para pôr em prática quando há dependência de fatores externos (licitações,} autorizações...) e a resultante foi:

Gráfico 2: Disponibilidade da gestão em pôr em prática sugestões dos colaboradores para melhoria do atendimento quando depende de fatores externos

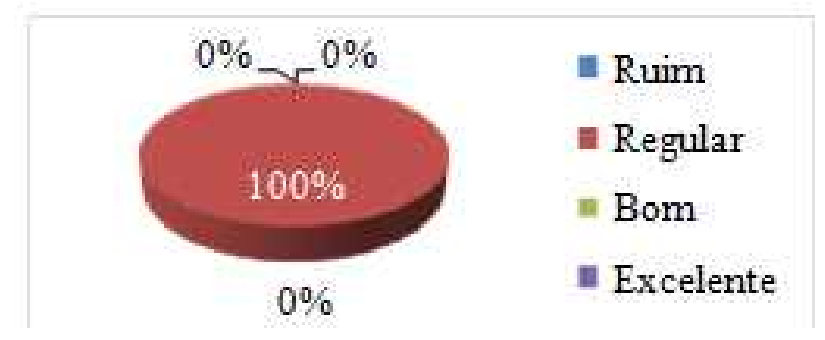

Fonte: autoria própria, dados coletados na pesquisa de campo, 2010

Com esse resultado pode ser analisada a concordância das duas gestões neste aspecto, onde ambas percebem como regular a disponibilidade para pôr em prática as sugestões dadas pelos funcionários, quando as mesmas dependem de fatores externos, ou seja, fatores burocráticos que envolvem licitações, autorizações da Secretaria de Saúde e/ou Prefeitura, demonstrando como boas idéias podem ser desperdiçadas, quando há excesso de burocracia (quando não autorizadas), ou quando há a demora neste processo (quando obtida autorização para pôr em prática), intervindo esse fator diretamente na iniciativa do colaborador em dar sugestões neste sentido, desmotivando o mesmo quando sua ideia não foi permitida para pôr em execução. A terceira e última parte da questão referese à qualidade das ideias/sugestões onde obteve-se o seguinte resultado:

Gráfico 3: Qualidade das sugestões dadas pelos colaboradores para melhoria da qualidade no atendimento

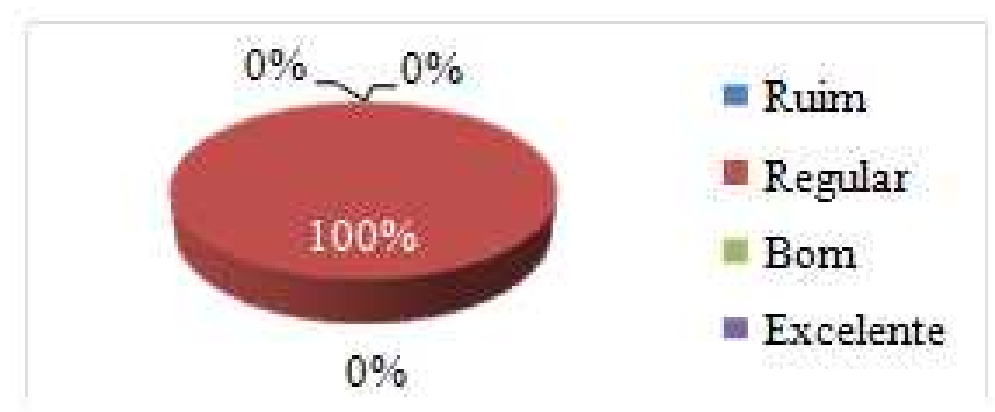

Fonte: autoria própria, dados coletados na pesquisa de campo, 2010 
Dessa maneira observa-se que as duas gestoras concordam que as ideias sugeridas pelos funcionários na construção da melhoria do atendimento carecem de qualidade, pois as mesmas avaliaram como regular. Demonstrando que o funcionário não deve apenas esforçar-se para contribuir com sugestões para melhorar a qualidade no atendimento, como também ser sensível para perceber a real necessidade do setor sendo, no entanto, necessária a opinião de todas as partes envolvidas no processo, inclusive do próprio usuário, pois só dessa forma é possível construir um atendimento em que todas as partes interessadas se satisfaçam e se complementem.

\subsection{Resultados obtidos com os colaboradores}

Os dados colhidos com os colaboradores da unidade diz respeito apenas aos profissionais que atuam diretamente com os clientes, excluindo-se as funções de dentista, auxiliar de consultório dentário (ACD), auxiliar de serviços gerais, auxiliar administrativo, farmacêutico (a), atendente de farmácia, guarda municipal e auxiliar de cozinha. Os profissionais abordados na pesquisa de campo atuam como: médico (a), enfermeiro (a), assistente social, nutricionista, auxiliar e técnico de enfermagem e laboratório, recepcionistas (que trabalham na marcação de consultas/exames) e atendentes de consultórios médicos (nível ambulatorial). Os setores que foram excluídos da pesquisa foram: CEO (Centro de Especialidades Odontológicas) e SAE (Serviço de Atendimento Especializado), pois os dois recebem recursos federais, farmácia, almoxarifado, copa e estatística.

Dentro da amostra citada anteriormente, existem na unidade 32 profissionais que atuam como nível superior e 48 que atuam como nível fundamental, médio ou médio/técnico, totalizando 80 profissionais. Dos que possuem nível superior 18 responderam ao questionário o que corresponde a $56 \%$, dos que possuem nível fundamental/médio/médio-técnico 36 responderam ao questionário o que corresponde a $75 \%$, no geral 54 responderam ao questionário o que corresponde a $68 \%$ do total da amostra, sendo, portanto, satisfatória por corresponder a mais de $50 \%+1$ do total de profissionais. Os dados demonstrados a seguir dizem respeito a todos os níveis de escolaridade. Existem algumas perguntas em que foi necessário colocar a opção não sabe opinar, que se refere aos que se colocaram como neutros no questionamento realizado.

Na primeira pergunta foi avaliada pelos colaboradores a estrutura física da sala/setor em que trabalham onde se obteve o seguinte resultado:

Gráfico 4: Estrutura física da sala/setor em que atuam os colaboradores

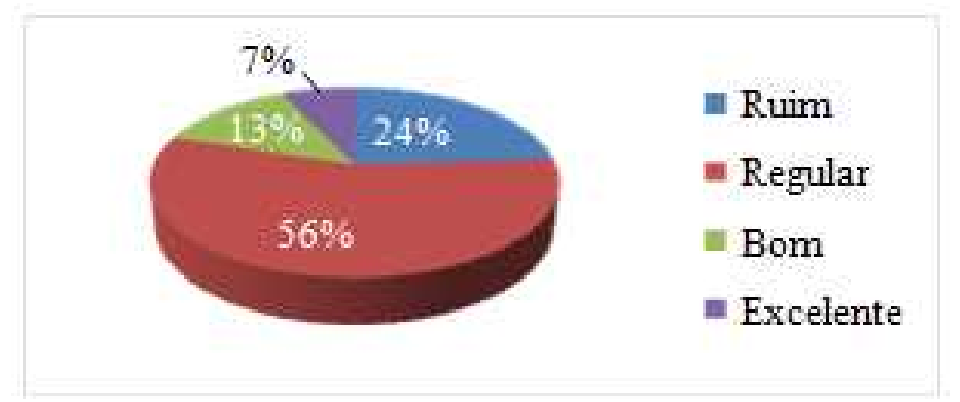

Fonte: autoria própria, dados coletados na pesquisa de campo, 2010 
Sendo assim, observa-se a insatisfação da maioria dos funcionários com relação ao seu ambiente de trabalho, que consideram regular esse fator com um percentual de $56 \%$, que somando-se aos que consideram ruim (24\%) totaliza $80 \%$. Esse resultado interfere diretamente na qualidade de vida dos servidores, assim como com a qualidade dos serviços a serem prestados, pois se a unidade não possui uma estrutura adequada, a qualidade fica prejudicada. Devendo para reverter tal situação solicitação da gestão da unidade, para posterior investimento da alta administração na reforma e melhoria da estrutura da unidade. E, ainda para que se obtenha a aprovação absoluta dos colaboradores, ouvir as suas necessidades em termos estruturais e tentar da melhor maneira possível satisfazê-las, já que eles fazem parte integrante da equipe de trabalho e percebe as dificuldades enfrentadas no seu dia-a-dia.

A seguir foi indagado quanto à interação existente entre gestor e colaborador em eventos realizados pela unidade como: festas e reuniões, no sentido criar vínculos e trocar ideias entre os envolvidos, onde foi avaliada a iniciativa da gestão na realização dos mesmos e o resultado foi:

Gráfico 5: Quanto à iniciativa da gestão em promover reuniões/festas no sentido de criar vínculos e trocar ideias entre os envolvidos

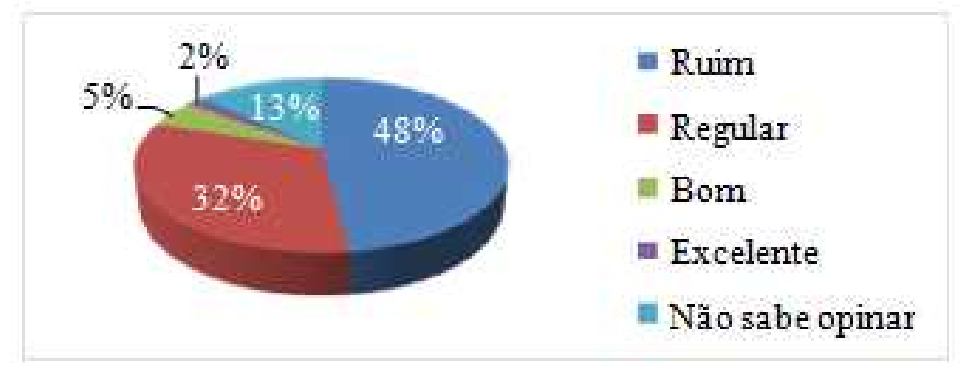

Fonte: autoria própria, dados coletados na pesquisa de campo, 2010

Dessa forma, pode ser percebido que a maioria dos entrevistados (48\%) avalia a iniciativa da gestão neste aspecto ruim e somado aos que consideram regular esse percentual atinge $80 \%$, sendo esse fator importante para a unidade da equipe de trabalho.

A seguir foi questionado quanto ao espaço dado ao colaborador na construção da melhoria do atendimento, onde o resultado obtido foi:

Gráfico 6: Quanto ao espaço dado ao colaborador na construção da melhoria do atendimento

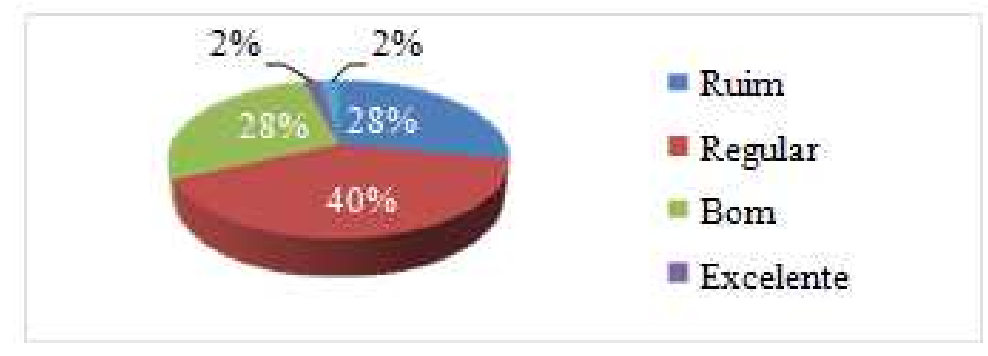

Fonte: autoria própria, dados coletados na pesquisa de campo, 2010 
Neste item constata-se que $40 \%$ dos servidores consideram regular o espaço dado na construção da melhoria do atendimento e que somado aos que avaliaram como ruim (28\%) esse percentual eleva-se para $68 \%$ do total. Neste caso torna-se necessário que haja o diálogo entre as partes envolvidas para que as mesmas entrem num consenso do que é melhor para que o cliente seja bem atendido.

Todos os questionamentos aqui realizados apontam que a maior parte dos servidores estão insatisfeitos com os seus trabalhos, o que faz com que a gestão tanto da unidade como da Secretaria Municipal de Saúde e da própria Prefeitura possam levar em consideração e realizar políticas necessárias a inversão desse percentual, contribuindo para que os colaboradores realmente "vistam a camisa" da organização e se comprazam em estar executando suas atividades laborais. Os aspectos analisados contribuem para o direcionamento dessas políticas, podendo ser complementado através de um estudo mais detalhado e com um percentual maior de entrevistados.

\subsection{Resultados obtidos com os clientes}

Com base numa estimativa de pacientes atendidos durante um mês de atendimento (período da pesquisa), excluindo-se os sábados, domingos e feriados (dias úteis: 20 dias) e sendo o turno analisado o da manhã, chegou-se a uma média de 10\% dessa demanda que equivale a 108 pacientes e obteve-se o total de 109 questionários respondidos, sendo por isso a amostra considerada satisfatória. Houve a necessidade de inclusão em algumas questões a opção não sabe opinar que ocorre quando a realidade questionada não condiz com a vivenciada pelos clientes.

Pôde ser percebido durante a aplicação dos questionários que o nível de escolaridade e poder aquisitivo dos clientes tiveram interferência significativa nas respostas referentes à qualidade dos serviços prestados e também pela falta de hábito por parte deles de participar de avaliações como esta, assim como a falta de conscientização da importância de que, de acordo com as respostas obtidas será possível direcionar e solucionar da melhor forma possível os problemas existentes, obtendo com isso a melhoria da qualidade no atendimento.

A primeira questão trata-se a respeito dos materiais quanto à disponibilidade para atendimento nas salas de curativo, coleta de exames e vacina onde o resultado obtido foi o seguinte:

Gráfico 7: A respeito dos materiais disponíveis para atendimento nas salas de curativo, coleta de exames e vacina

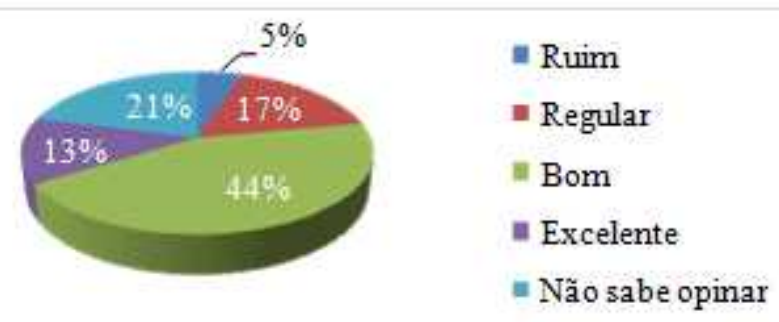

Fonte: autoria própria, dados coletados na pesquisa de campo, 2010 
É perceptível que a maior parte descreveu como bom (44\%) sobre o questionamento realizado, devendo ser considerado, no entanto, o quantitativo que opinaram como ruim ou regular.

Na segunda questão indagou-se sobre a marcação de consultas e exames feitos na unidade, que foi dividida em duas partes. Na primeira parte questionou-se sobre o tempo de espera na fila e o resultado alcançado foi:

Gráfico 8: Sobre o tempo de espera na fila nas marcações de consultas e exames feitos na unidade

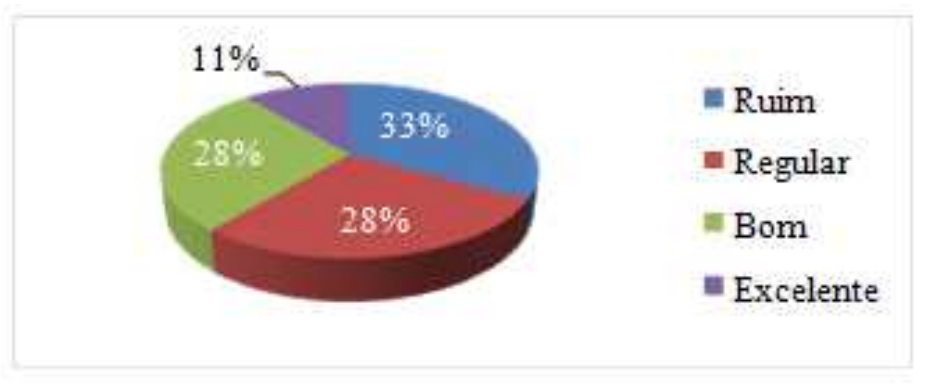

Fonte: autoria própria, dados coletados na pesquisa de campo, 2010

Dessa forma, percebe-se que 33\% avaliaram como ruim este aspecto, podendo ser vista estratégias para reverter este índice de insatisfação. Na segunda parte foi questionado sobre o acesso às marcações e o resultado foi:

Gráfico 9: Sobre o acesso às marcações

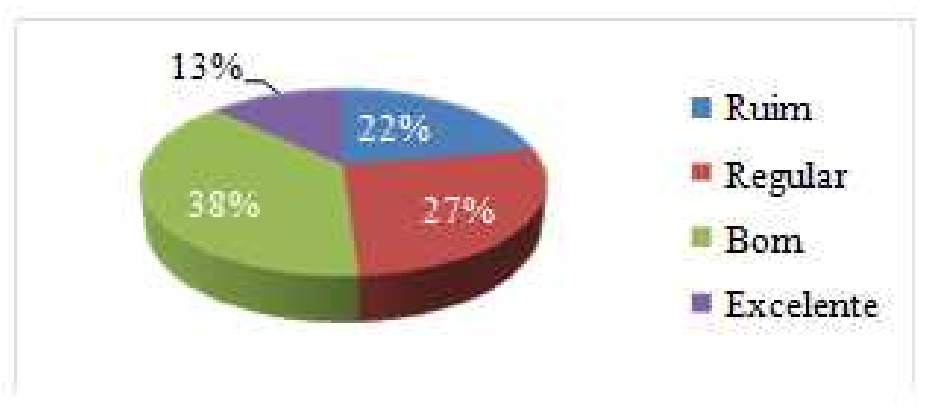

Fonte: autoria própria, dados coletados na pesquisa de campo, 2010

Com isso percebe-se que $38 \%$ consideram como bom o acesso às marcações, porém deve ser analisado que o percentual que separa ruim/regular de bom/excelente é de apenas $2 \%$, podendo ser um ponto a ser melhorado na unidade.

Apesar da maioria das respostas terem apontado como bom o resultado, deve ser analisado, porém que o percentual que considerou como ruim ou regular foi muito elevado devendo, portanto, ser discutido por toda a equipe de trabalho soluções para diminuir este índice de insatisfação. 


\section{CONSIDERAÇÕES FINAIS}

É preciso uma mudança de paradigmas para que assim as organizações públicas possam se dispor a aderir às propostas do Programa que possui como principal estratégia a adesão espontânea por entender que a transformação só é possível pela vontade mútua da maioria que integra uma organização. Sendo o principal foco desta pesquisa a releitura e reflexão por parte dos clientes internos para que os mesmos possam exercer a qualidade em seus atendimentos ainda que a organização não seja adesa ao Programa da Qualidade no Serviço Público (PQSP), pois é preciso crer que é preciso mudar e o desafio maior é a mudança com as ferramentas que são acessíveis no momento.

A unidade estudada poderá através das análises apresentadas neste trabalho, direcionar ações no intuito de melhorar o nível de satisfação tanto dos colaboradores quanto dos clientes e a partir de uma internalização de todas as partes envolvidas de que o trabalho em equipe é uma forma de se melhorar as relações interpessoais e de que a formação de equipes multidisciplinares e dinâmicas é possível melhorar a qualidade dos serviços oferecidos ao público. 


\section{REFERÊNCIAS}

ANDRADE, M. Introdução à metodologia do trabalho científico: elaboração de trabalhos de graduação. 7. ed. São Paulo: Atlas, 2006.

BRASIL. Assessoria de Comunicação. Entendendo o SUS. Brasília, DF: Ministério da Saúde/Governo Federal, 2006. Disponível em: <http://portal.saude.gov.br/portal/arquivos/pdf/cartilha_entendendo_o_sus_2007.pdf>. Acesso em: 02 nov. 2010. (20:57).

BRASIL. Repertório do Programa Qualidade no Serviço Público - PQSP. Brasília: Ministério do Orçamento e Gestão, memo, 2002. Disponível em: <http://www.google.com.br/search?hl=ptBR\&q= repertorio+2002+pqsp\&aq=f\&aqi=g10\&aql=\&oq=\&gs_rfai=>. Acesso em: 16 out. 2010. (18:24).

CERVO, A; BERVIAN, P; DA SILVA, R. Metodologia científica. 6. ed. São Paulo: Pearson Prentice Hall, 2007.

GIL, A. Gestão de pessoas: enfoque nos papéis profissionais. São Paulo: Atlas, 2007.

PALADINI, E. Gestão da qualidade: teoria e prática. 2. ed. São Paulo: Atlas, 2008.

REBELO, P. Qualidade em saúde. Rio de Janeiro: Qualitymark, 1995.

ZUANETTI, R; HARGREAVES, L; LEE, R et al. Qualidade em prestação de serviços. 2. ed. Rio de Janeiro: Ed. Senac Nacional, 2001. 


\title{
GESTÃO DA INOVAÇÃO, TEORIAS E PRÁTICAS APLICÁVEIS ÀS AÇÕES EMPRESARIAIS
}

\author{
Maria Aparecida Fernandes \\ Universidade Federal de Minas Gerais - UFMG \\ Washington Moreira Cavalcanti \\ Universidade Federal de Minas Gerais - UFMG
}

\section{RESUMO}

A inovação, na sociedade contemporânea, é um dos fatores associados ao desenvolvimento social e econômico das nações. Mota (2011) destaca que o conceito de inovação, de modo geral, é correlacionado com pesquisa e desenvolvimento (P\&D), mas distinto e mais amplo, estando necessariamente associado à aplicação do conhecimento. A respeito da inovação e de sua gestão em empresas, apresenta-se um estudo bibliográfico sobre a aplicação e utilização de ferramentas de gestão no processo de inovação. Nas empresas, a inovação não pode ser vista apenas como uma oportunidade inerente de criação de um novo negócio ou de crescimento de mercado, mas, acima de tudo, como uma forma de redefinir a organização.

$\mathrm{O}$ artigo objetiva descrever as práticas de gestão da inovação, apresentando um levantamento bibliográfico sobre quais destas práticas estão arranjadas no contexto de desenvolvimento da inovação e que podem aplicadas nas empresas em um ambiente de inovação no Brasil.

\section{Palavras-chave:}

Inovação; Gestão da inovação; P\&D; Empreendedorismo..

\begin{abstract}
Innovation in contemporary society is one of the factors associated with the social and economic development of nations. Mota (2011) emphasizes that the concept of innovation, in general, is correlated with research and development ( $R \& D)$, but distinct and broader, being necessarily associated to the application of knowledge.

Regarding innovation and its management in companies, a bibliographic study is presented on the application and use of management tools in the innovation process. In companies, innovation can not be seen merely as an inherent opportunity to create a new business or market growth, but above all, as a way
\end{abstract}

to redefine the organization. The article aims to describe the management practices of innovation, presenting a bibliographical survey about which of these practices are arranged in the context of innovation development and that can be applied in companies in an innovation environment in Brazil.

\section{Keywords:}

Innovation; Innovation management; P\&D;

Entrepreneurship. 
INTRODUÇÃO

A inovação, na sociedade contemporânea, é um dos fatores associados ao desenvolvimento social e econômico das nações. Mota (2011) destaca que o conceito de inovação, de modo geral, é correlacionado com pesquisa e desenvolvimento (P\&D), mas distinto e mais amplo, estando necessariamente associado à aplicação do conhecimento.

Este artigo pretende compartilhar o que tem se apresentado sobre inovação no currículo da Academia e também fornecer uma introdução às ferramentas, às técnicas e ao conhecimento necessário para desenvolver ainda mais a inovação e o empreendedorismo como pensamento crítico, construção do saber e negócios. Este tema abrange as abordagens práticas e teóricas para a formação, tais como, o ensino baseado em projetos e problemas; a integração multimídia; o ensino em pares; a pedagogia em grupo, e os processos da construção do pensamento. A respeito da inovação e de sua gestão em empresas, apresenta-se um estudo bibliográfico sobre a aplicação e utilização de ferramentas de gestão no processo de inovação. Nas empresas, a inovação não pode ser vista apenas como uma oportunidade inerente de criação de um novo negócio ou de crescimento de mercado, mas, acima de tudo, como uma forma de redefinir a organização. No Brasil, muito pouco tem se feito com relação ao amplo desenvolvimento da gestão da inovação.

A inovação pré-dispõe o compromisso para a prática educativa, transforma-se em pano de fundo para a construção de novos conhecimentos dinamizados, não pelo paradigma vigente, mas pela atividade organizacional vivenciada e repensada, sendo este um dos pilares do empreendedor para a inovação.

O problema primordial neste estudo é: “De que forma a utilização de práticas adequadas a cada etapa do processo de desenvolvimento de um conceito inovador pode contribuir para o incremento do processo de inovação, de modo a aumentar o potencial de geração de valor, seja social ou econômico". O artigo objetiva descrever as práticas de gestão da inovação, apresentando um levantamento bibliográfico sobre quais destas práticas estão arranjadas no contexto de desenvolvimento da inovação e que podem aplicadas nas empresas no Brasil.

Espera-se que os resultados deparados permitam auxiliar no estudo, divulgação e também o desenvolvimento de ferramentas e metodologias de gestão da inovação que auxiliem no aumento das iniciativas inovadoras de sucesso em nosso país.

\section{Metodologia}

O método de pesquisa empregado para realização deste artigo foi a pesquisa bibliográfica e documental. Segundo Gil (2008), a pesquisa bibliográfica é desenvolvida com base em material já elaborado, constituído principalmente de livros e artigos científicos. A principal vantagem da pesquisa bibliográfica está no fato de permitir ao investigador a cobertura de uma gama de fenômenos muito mais ampla do que aquela que poderia pesquisar diretamente Ainda segundo Gil (2008), a pesquisa é 
como um diálogo crítico e criativo com a realidade, culminando com a elaboração própria e com a capacidade de intervenção. Em tese, pesquisa é a atitude de "aprender a aprender", e, como tal, faz parte de todo processo educativo e de emancipação do conhecimento.

Esta revisão bibliográfica foi efetivada a partir de vasto material publicado, constituído principalmente de livros, artigos científicos e publicações periódicas, jornais, dissertações e teses, sobre os temas: Inovação, Gestão da Inovação e Ferramentas de Gestão da Inovação. Esta revisão serviu para elucidar as investigações, análises e conclusões sobre o tema "Inovação".

Elaborado este levantamento, foram compilados os dados e analisados os textos que estivessem alinhados com o tema principal para que fosse possível alcançar os resultados almejados da pesquisa.

\section{Inovação nas empresas}

A legislação brasileira da inovação é recente e tem origem já na década de 90 . Até então, a legislação cobria simplesmente atividades de C\&T (Ciência e Tecnologia), predominantemente em instituições superiores de ensino e pesquisa, não era atrelada à visão linear de P\&D -Pesquisa e Desenvolvimento, para gerar inovação. A criação do Fundo Nacional de Desenvolvimento Científico e Tecnológico (FNDCT), por meio do Decreto-Lei no 719 de1969, que teve a finalidade de apoiar financeiramente programas e projetos prioritários de desenvolvimento científico e tecnológico, foi um dos marcos da legislação de P\&D no país.

A Lei de Inovação federal é a Lei no 10.973, de 2 de dezembro de 2004, regulamentada pelo Decreto no 5.563 de 11 de Outubro de 2005. Segundo Vettorato (2017), esta lei teve como referencia básica a lei francesa de inovação, "Loi sur l'innovation et la recherche 1999 - França". A Lei de Inovação federal regula os incentivos à inovação e à pesquisa científica e tecnológica no ambiente produtivo, estabelecendo medidas, com vistas à capacitação e ao alcance da autonomia tecnológica e ao desenvolvimento industrial do País, nos termos dos artigos 218 e 219 da Constituição Federal.

A lei traz conceitos e definições, para seu entendimento, entre elas:

- Inovação: é a introdução de novidade ou aperfeiçoamento no ambiente produtivo ou social que resulte em novos produtos, processos ou serviços;

- Instituição Científica e Tecnológica - ICT: é o órgão ou entidade da administração pública que tenha por missão institucional, dentre outras, executar atividades de pesquisa básica ou aplicada de caráter científico ou tecnológico.

- Núcleo de Inovação Tecnológica - NIT: é o núcleo ou órgão constituído por uma ou mais ICT com a finalidade de gerir sua política de inovação.

A definição de inovação na Lei de Inovação federal é bastante genérica, com foco na inovação tecnológica. Ela descreve, com abrangência, como sendo a introdução de novidade ou aperfeiçoamento no ambiente produtivo que resulte em novos produtos, processos ou serviços.

As leis de inovação estaduais derivam da Lei de Inovação Federal, permeando para o ambiente estadual, os preceitos da lei federal. O quadro a seguir apresenta a relação de estados que já possuem leis estaduais de inovação proclamadas. 
Quadro 1 - Relação de Leis Estaduais de Inovação.

\begin{tabular}{|c|c|c|}
\hline Estado & Legislação & Entrada em vigor \\
\hline Alagoas & Lei Estadual n².117, & 12 de Novembro de 2009 \\
\hline Amazonas & Lei Ordinária n 3.095 & 17 de Novembro de 2006 \\
\hline Bahia & Lei Estadual no 11.174 & 09 de Dezembro de 2008 \\
\hline Ceará & Lei Estadual 14.220 & 16 de Outubro de 2008 \\
\hline Goiás & Lei Estadual $n^{\circ} 16.922$. DE & 08 de Fevereiro de 2010. \\
\hline Mato Grosso & Lei Complementar $n^{2} 297$ & 07 de Janeiro de 2008 \\
\hline Minas Gerais & Lei Estadual n² 17.348 & 17 de Janeiro de 2008 \\
\hline Pernambuco & Lei Estadual $n=13.690$ & 16 de Dezembro de 2008 \\
\hline Rio de Janeiro & $\begin{array}{l}\text { Lei Estadual } n^{\circ} 5.361 \\
\text { Decreto Estadual } n^{\circ} 42.302\end{array}$ & $\begin{array}{l}29 \text { de Dezembro de } 2008 \\
12 \text { de fevereiro de } 2010\end{array}$ \\
\hline Rio Grande do Sul & Lei Estadual n 13.196 & 13 de Julho de 2009 \\
\hline São Paulo & $\begin{array}{l}\text { Lei Complementar n? } 1049 \\
\text { Decreto n? } 53.141 \text {. }\end{array}$ & $\begin{array}{l}19 \text { de Junho de } 2008 \\
19 \text { de Junho de } 2008\end{array}$ \\
\hline Santa Catarina & Lei Estadual $n=14.328$ & 15 de Janeiro de 2008 \\
\hline Sergipe & Lei Estadual n² 6.794 & 02 de Dezembro de 2009 \\
\hline
\end{tabular}

Fonte: IBGE, 2005.

Apesar da definição de leis e incentivos fiscais que regem o processo de inovação, em relação às Empresas como um todo, é preciso destacar que elas não têm alcançado de forma linear a liberação dos incentivos fiscais possíveis. O Ministério da Ciência, Tecnologia e Inovação - MCTI tem endurecido muito com as organizações, ao definir pontos diversos a serem analisados, além de destacar o que ele, o MCTI, não considera atividades de P\&D\&I para efeito dos incentivos da lei.

Diante da intenção dos projetos percebe-se, que as experiências inovadoras já estão ocorrendo nas organizações de forma tímida. Isso quer dizer que pequenas rupturas já estão em curso, ou seja, gestores estão reestruturando suas percepções gerenciais e investem em diferentes meios de capacitar e desenvolver novas idéias. Nesse contexto, Cunha et al (2001) afirma que as inovações que contribuem para a melhoria de uma organização e da aprendizagem na universidade podem dar-se em diferentes patamares e de variadas formas.

Quadro 2 - Tipos de Inovação Tecnológica - Produto

INOVAÇÃO DE PRODUTO

$\begin{array}{lll}\begin{array}{l}\text { Produto tecnologicamente } \\ \text { novo }\end{array} & \begin{array}{l}\text { É um produto cujas características fundamentais (especificações } \\ \text { pretendidos, software ou outro componente imaterial incorporado) usos }\end{array} & \text { diferem } \\ \text { (bem ou serviço industrial) } & \text { significativamente de todos os produtos previamente produzidos. }\end{array}$

\begin{tabular}{ll}
\hline $\begin{array}{l}\text { Melhoria incremental de } \\
\text { produto }\end{array}$ & $\begin{array}{l}\text { Refere -se a um produto previamente existente, cujo desempenho foi substancialmente } \\
\text { aumentado ou aperfeiçoado tecnologicamente. Um produto simples pode ser aperfeiçoado }\end{array}$ \\
(bem ou serviço industrial) & $\begin{array}{l}\text { (no sentido de se obter um melhor desempenho ou um menor custo) através da utilização de } \\
\text { matérias primas ou componentes de maior rendimento. Um produto complexo, com vários } \\
\text { componentes ou subsistemas integrados, pode ser aperfeiçoado via mudanças parciais em um } \\
\text { dos componentes ou subsistemas. }\end{array}$
\end{tabular}

Não são incluídas:

As mudanças puramente estáticas ou de estilo e a comercialização de produtos novos integralmente desenvolvidos e produzidos por outra empresa.

Fonte: Adaptado de Vettorato (2017) 
Para o meio empresarial, a inovação não pode ser vista apenas como uma oportunidade de iniciar um negócio, crescer em um negócio existente ou mesmo sobreviver, mas, uma maneira de definir os rumos da indústria, do negócio ou mesmo da comunidade onde a organização ou entidade está inserida (DAVILA; EPSTEIN; SHELTON, 2007), sendo difícil encontrar argumentos que se posicionem contra a premissa de que a inovação tende a ser cada vez mais importante nos próximos anos.

Segundo Vettorato (2017) a portaria do MCTI n 327/10, descreve que uma Inovação Tecnológica é definida como a concepção de novo produto, ou processo de fabricação, bem como a agregação de novas funcionalidades e características ao produto, ou processo que implique melhorias incrementais e algum efetivo ganho de qualidade e produtividade, resultando maior competitividade no mercado ou setor em que esteja inserido.

Segundo dados da Pintec de 2003 (IBGE, 2005), tendo por referência o "principal produto tecnologicamente novo ou substancialmente aprimorado lançado no mercado", são oferecidas as seguintes alternativas de inovação:

a) Aprimoramento de um produto existente;

b) Produto Novo para a empresa, mas já existente no mercado nacional;

c) Produto Novo para o mercado nacional, mas já existente no mercado mundial; e

d) Produto Novo para o mercado mundial.

De acordo com este levantamento, o grau de novidade de uma inovação está em um ponto de uma escala contínua (continuum) localizada entre um extremo (totalmente incremental) e outro extremo (totalmente radical).

Com as informações elaboradas pela academia até o momento, associado às normativas e leis em curso, pode-se gerar um conhecimento básico sobre inovação e perceber que, independentemente do tipo de inovação a ser adotado, é primordial que ele tenha como resultado um valor de conquista, de ganho de valor.

A inovação sistemática, portanto, consiste na busca deliberada e organizada de mudanças, e na análise sistemática das oportunidades que tais mudanças podem oferecer para a inovação econômica ou social (DRUKER, 1987).

Chiavenato (2007) cita que uma pequena empresa não pode ser considerada atividade empreendedora, a não ser que esta tenha aplicado ou empreendido algum tipo de inovação, o empreendedorismo não trata apenas de pequenas empresas e novos empreendimentos. Não aborda apenas a criação de novos produtos ou serviços, mas, sim, inovações em todos os âmbitos do negócio.

\subsection{Gestão da inovação}

A Gestão da Inovação, também denominada Gestão Estratégica da Inovação, é um processo estruturado, contínuo e facilitador para que uma empresa gere mais inovação e crie mais valor a estas inovações (BESSANT e TIDD, 2009).

Fator importante para o conhecimento da inovação é o grau de novidade que a mesma apresenta, para Bessant \& Tidd (2009) a diferença entre inovação incremental e inovação radical, ocorre quando 
há a enorme diferença entre se adicionar melhorias e modificações em algo já existente, e se criar um conceito, seja de produto ou serviço, que seja totalmente novo. A Gestão da inovação compreende a busca por fatores que venham a determinar o sucesso ou fracasso de um projeto, dentre eles quatro fatores centrais, como citado por Bessant e Tidd (2009):

1. Compreender o que se tenta gerenciar.

2. Compreender o como.

3. Compreender o quê, o porquê e o quando da atividade de inovação.

4. Compreender que isso é um alvo móvel.

A ação de gerenciar a inovação em uma organização é basear-se em mais que uma boa idéia, é preciso calcular estrategicamente e aprender com o processo. Para Bessant e Tidd (2009) a inovação assume formas muito variadas, mas podem ser resumidas em quatro tipos diferentes, como pode-se verificar:

I. Inovação de produtos

II. Inovação de processos

III. Inovação de posição

IV. Inovação de paradigma

Faz-se importante salientar que muitas vezes é possível que se tenha dificuldades em se diferenciar os tipos de inovação, pelo fato de serem parecidas em alguns casos e se aplicarem a mais de um tipo de caso e ao mesmo tempo.

\subsection{Inovação Incremental, Semi-radical e Radical}

Quando se analisa apenas os aspectos tecnológicos, fica fácil diferenciar uma inovação incremental de uma inovação radical. Tidd, Bessant e Pavitt (2008), classificam os tipos de inovação quanto à sua intensidade ou grau. Quando analisados simultaneamente os aspectos tecnológicos e as características do modelo de negócio, surgem correlações que possibilitam a identificação de 3 grupos diferentes de inovações: as radicais, as semi-radicais e as incrementais.

Figura 1 - Modelo de Inovação Incremental, Semi-radical e Radical.

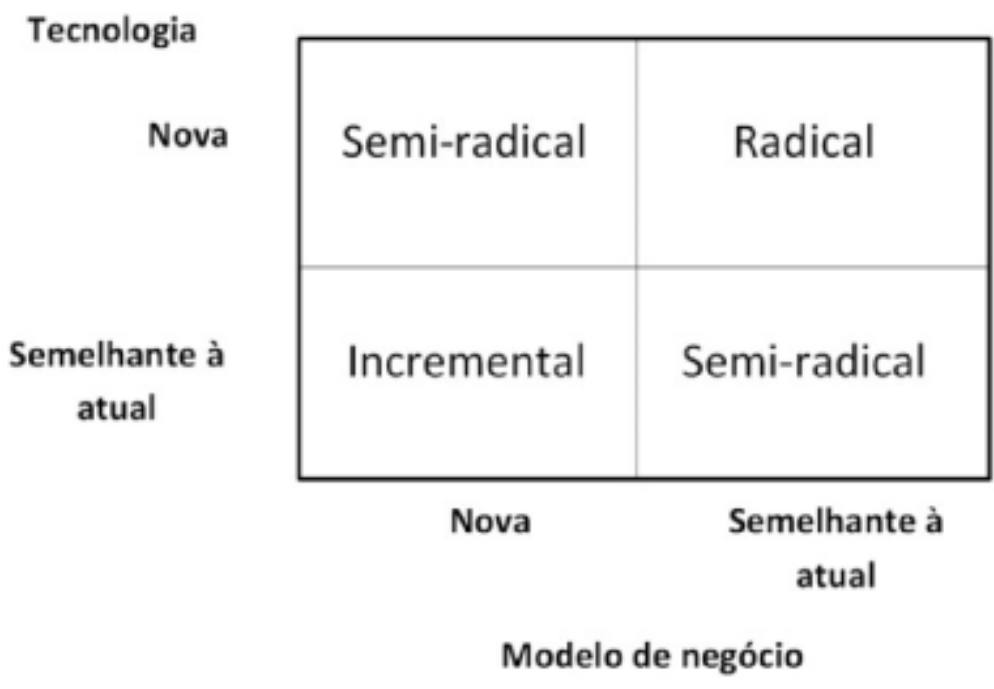

Fonte: Adaptado de Tidd, Bessant e Pavitt (2008) 
Nem todas as inovações são criadas da mesma forma. Elas não apresentam os mesmos riscos nem proporcionam recompensas similares. O modelo de inovação geral é descrito por Tidd, Bessant e Pavitt (2008), como:

- A inovação incremental: é a forma predominante de inovação na maioria das empresas, seguidamente recebendo mais de $80 \%$ do investimento total das companhias em inovação.

- A inovação semi-radical: envolve mudança substancial no modelo de negócios ou na tecnologia de uma organização - mas não em ambas. Às vezes a mudança em uma dimensão é condicionada à mudança na outra, embora essa mudança concomitante possa não ser tão dramática ou revolucionária.

- Inovações radicais: são, pela própria natureza, investimentos de poucas probabilidades de retorno. A chave é manter um portfólio equilibrado de inovações radicais a fim de que o investimento possa suprir as necessidades do negócio.

Ainda de acordo com Tidd, Bessant e Pavitt (2008), uma inovação radical só ocorre quando há a introdução de uma nova tecnologia, simultaneamente com a implantação de um novo modelo de negócio. Nem todas as inovações são criadas da mesma forma. Elas não apresentam os mesmos riscos nem proporcionam recompensas similares. O modelo de inovação geral é descrito por Tidd, Bessant e Pavitt (2008), como:

- A inovação incremental: é a forma predominante de inovação na maioria das empresas, seguidamente recebendo mais de $80 \%$ do investimento total das companhias em inovação.

- A inovação semi-radical: envolve mudança substancial no modelo de negócios ou na tecnologia de uma organização - mas não em ambas. Às vezes a mudança em uma dimensão é condicionada à mudança na outra, embora essa mudança concomitante possa não ser tão dramática ou revolucionária.

- Inovações radicais: são, pela própria natureza, investimentos de poucas probabilidades de retorno. A chave é manter um portfólio equilibrado de inovações radicais a fim de que o investimento possa suprir as necessidades do negócio.

Ainda de acordo com Tidd, Bessant e Pavitt (2008),uma inovação radical só ocorre quando há a introdução de uma nova tecnologia, simultaneamente com a implantação de um novo modelo de negócio.

\section{3 "Inovação e Empreendedorismo", por Peter Drucker}

As "Empresas Empreendedoras", para Drucker (1987), proporcionam um excelente ambiente para a inovação, em que os membros da equipa estão ansiosos por inovar, existe o incentivo da liderança, em parte porque o crescimento e as recompensas andam de mãos dadas.

É possível questionar se o Empreendedorismo consegue ser sustentado sem a Inovação. A parte principal do trabalho apresentado por Drucker (1987) teve foco nas fontes de inovação. Druker relatou sete fontes diferenciadas de inovação: 
1. O inesperado;

2. Incongruências;

3. Necessidade de pensamento;

4. Estruturas de indústria e de mercado;

5. Demografia;

6. Mudança de percepções;

7. Novo conhecimento.

As empresas careceriam ser mais clarividentes na busca e na forma de aprender mais sobre as fontes de inovação. É curioso verificar que Drucker buscou entender como o processo de inovação ocorria na década de oitenta. Ele identificou uma série de eventos a se fazer e de não fazer relacionados a inovação:

A se Fazer
A. A inovação planejada começa com a análise de oportunidades;
B. A inovação é tanto conceitual como por percepção;
C. Para ser eficiente, a inovação tem de ser simples e direcionada;
D. Inovação eficiente começa com pequenos passos;
E. Uma inovação bem sucedida visa a liderança.

\section{A não Fazer:}

A. Não pensar que se sabe mais do que os outros;

B. Não diversifique, não perca o rumo e não tente fazer demasiadas tarefas de uma só vez;

C. Não tente inovar para o futuro. Inove para o presente!

Fatores como apoio e subvenções à pesquisa e desenvolvimento conjunto entre Universidades e empresas também contribuem positivamente para a criação de oportunidades de colaboração e inovação dentro das organizações.

\section{Modelo de Gestão Estratégica da Inovação Tecnológica}

Na visão desse modelo, a essência do gerenciamento do processo de inovação tecnológica consiste na mobilização e coordenação dos recursos e atores internos da corporação, tais como: P\&D, marketing, operações, RH, financeiro, novos negócios; além de atores e recursos externos à empresa como os clientes, fornecedores, instituições de pesquisa, instituições de fomento, etc.

A inovação é o elemento chave para a concretização do crescimento sistemático das receitas, e um diferencial importante para aumentar os percentuais nos lucros da empresa. Não há organização que seja capaz de crescer somente por redução de custos e reengenharia. 
Figura 2 - Modelo de Gestão Estratégica da Inovação Tecnológica

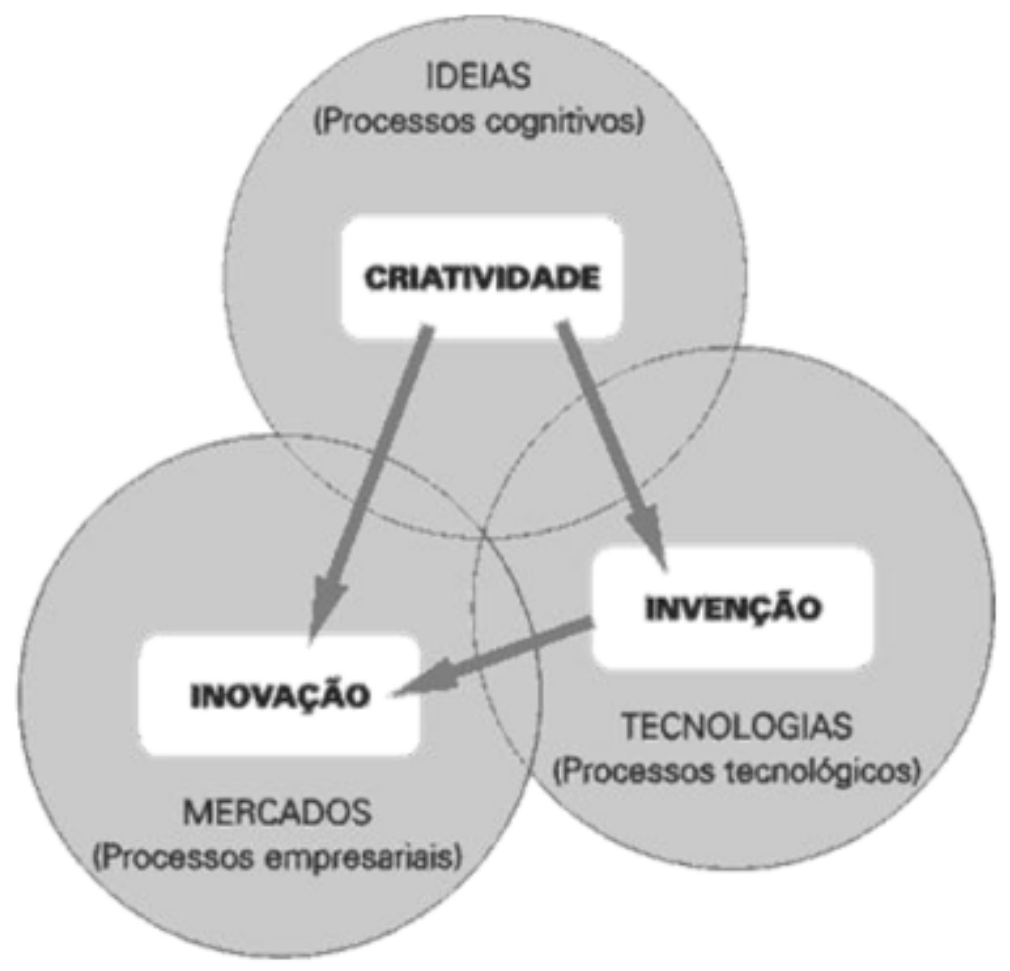

Fonte: Adaptado de Barney, (2002)

Para explorar oportunidades tecnológicas e de mercado alinhadas às prioridades da estratégia competitiva, alguns desafios se sobressaem nesse processo, como dificuldades características da gestão da inovação:

- A gestão da inovação busca integrar as esferas da tecnologia (engenharia, P\&D) com a do(s) mercado(s) que a empresa serve ou busca desenvolver; tecnologia não é fim em si mesmo, mas instrumento da diferenciação competitiva sustentada (Barney, 2002).

- Um trade-off permanentemente enfrentado na gestão da inovação tem a ver com a necessidade de combinar a geração de inovações incrementais com a geração de inovações radicais, de maneira estruturada, numa mesma corporação; as lógicas desses dois processos são distintas (Christensen, 1997);

- Um desafio que se evidenciou mais recentemente (em relação aos anteriores) está associado à grande flutuação da configuração das cadeias de valor que hoje marca a maior parte dos ambientes de negócios; assim, inovação não se refere necessariamente apenas a produto, processos e serviços, mas também ao modelo de negócios, isto é, inovação na forma de se inserir em uma cadeia de valor (Chesbrough, 2007).

De acordo com Davila (2007) a inovação do modelo de negócios é quase tão importante quanto a inovação tecnológica. A gestão estratégica da inovação busca estruturar, sob uma perspectiva estratégica, recursos, processos, ferramentas e práticas organizacionais de maneira sistêmica, a fim de que a inovação não seja algo espontâneo ou aleatório na empresa, mas um processo organizado, crescente e permanente. 


\subsection{Inovação Reversa}

Segundo Govindarajan e Trimble (2012) a inovação que sempre esteve atrelada as grandes corporações de países desenvolvidos, e posteriormente migraram para os em desenvolvimento, altera seu padrão ao inverter o fluxo da inovação, ou seja, a Inovação Reversa tem seu início pelas subsidiárias de empresas ou por meio de outras corporações de países em desenvolvimento.

Deve-se analisar que a Inovação Reversa pode ser também compreendida como uma tática utilizada pelas matrizes das corporações para ampliar seu alcance de vendas, atingindo um novo mercado e assim, alcançar um impacto global:

"[...] qualquer inovação que seja adotada em primeiro lugar nos países em desenvolvimento. Sempre de forma surpreendente, essas inovações desafiam a gravidade fluindo para cima" GOVINDARAJAN E TRIMBLE (2012).

Investir em PD\&I é um diferencial, mas é igualmente importante ter uma combinação de talentos, conhecimentos, ferramentas e processos voltados para a inovação e alinhados às estratégias de negócios da empresa.

Para Govindarajan e Trimble (2012) Inovação Reversa é a habilidade de inovar especificamente para os mercados emergentes:

- Necessidade de criar mercados, inovar para atender necessidades específicas como performance, infra-estrutura, sustentabilidade, leis locais, etc.;

- Futura exportação das inovações para os países desenvolvidos = Inovação Reversa.

Empresas de alto desempenho inovam ao dar sustentação tanto a novos modelos de negócios quanto a tecnologias aprimoradas, como descritas no modelo de Inovação Reversa.

Figura 3 - Modelo de Inovação Reversa

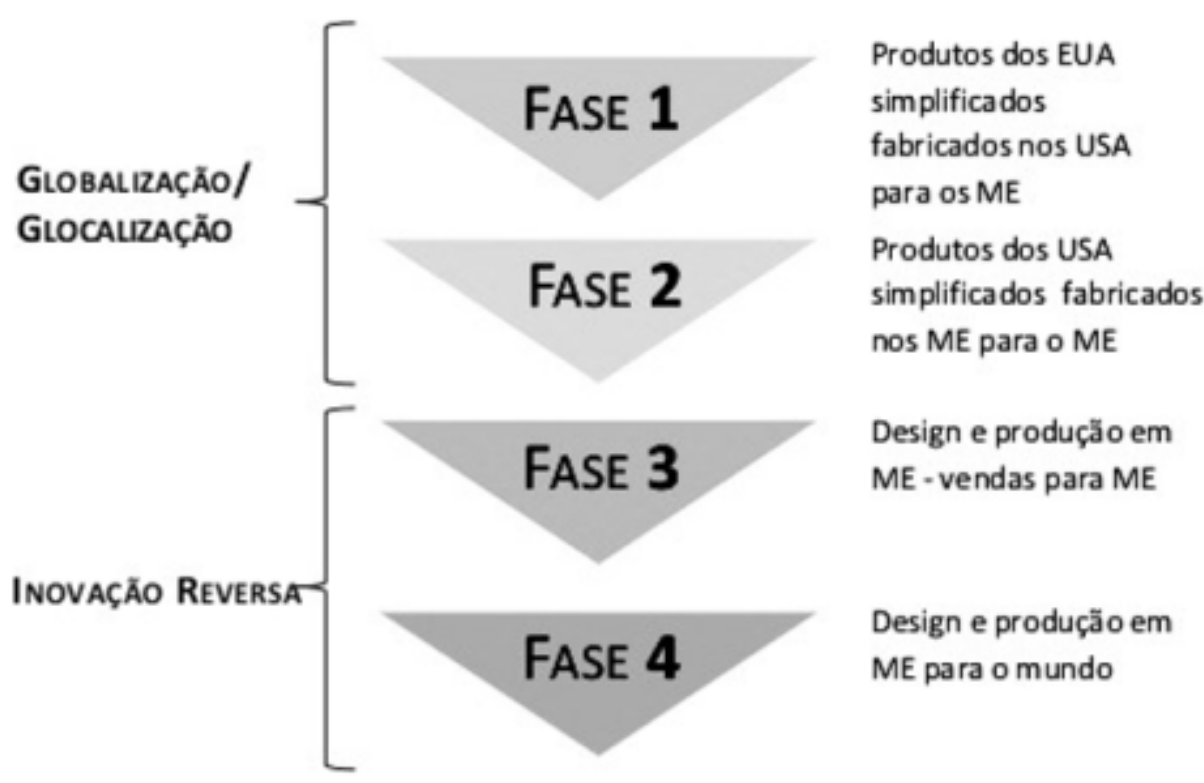

Fonte: Adaptado de Govindarajan e Trimble (2012) 
Govindarajan e Trimble (2012) propõem soluções mais baratas e convenientes que poderiam inclusive ser exploradas por diversos tipos de empreendimentos organizacionais. Para os autores, conquistar o mercado com uma idéia inovadora pode ser muito entusiasmador, mas alcançá-lo demanda um trabalho que vai além das sessões de Braimstorm e análises estratégicas, sendo necessário avaliar todas as armadilhas que estão do outro lado da inovação. Uma idéia que propõe inovação precisa ser experimentada de forma disciplinada, responsabilizando equipes e diagnosticando diretrizes e norte para as organizações (GOVINDARAJAN e TRIMBLE, 2012).

\subsection{Ps da Gestão da Inovação}

Os fatores descritos em Propósito, Processos, Pessoas e Políticas, chamados de os 4 Ps da gestão com foco na inovação, foi uma metodologia desenvolvida para a realidade de pequenas e médias empresas, mas por sua abrangência, pode ser aplicado em empresas de todos os portes. (BRANSON, 1998 apud TIDD; BESSANT; PAVITT, 2008).

Esta proposta de gestão tem como lema a organização da viabilidade e visão da inovação, busca sua aplicação à realidade de cada empreendimento. Conforme Junior et al (2008), o ambiente interno da organização é a base para todos os outros componentes do gerenciamento da inovação, o que propicia disciplina e estrutura a proposta inovadora.

Os 4Ps da inovação seguem a mesma lógica e consistem em quatro áreas de decisões que são o propósito, os processos, as pessoas e as políticas, que o empreendedor precisa considerar para fortalecer e ou consolidar a capacidade de inovação de seu negócio. As organizações bem-sucedidas combinam mudança em tecnologia e mudança no modelo de negócio para criar inovação.

Quadro 3 - Os 4Ps da Gestão da Inovação

\section{INOVAÇÃO DE PRODUTO}

A primeira reflexão diz respeito ao propósito da inovação para o seu negócio. Assim, é preciso entender que as inovações são idéias que contribuem, em última instância, para o aumento de entradas de caixa (vendas) e para a redução das saídas de caixa (despesas, custos, gastos etc.) da empresa.

Propósito de inovar:

Depois que a empresa esclarecer que definição de inovação irá empregar seu

Processos para inovar: alinhamento com a estratégia e as metas, deve definir os processos para começar a transformar novas idéias em fontes de lucro.

Para que os processos de inovação funcionem, tenha em sua empresa pessoas que se encaixem em duas categorias: empreendedoras (as que percebem oportunidades,

Pessoas para inovar: $\quad$ fazem sugestões formais na forma de um projeto ou plano de negócio e têm perseverança até conseguirem a implementação) e as gestoras (são flexíveis, mas orientadas para transformar conceitos intangíveis em resultados mensuráveis).

Políticas para inovar:

De nada adianta a empresa saber definir o que é inovação e como ela contribui para o resultado do negócio, definir os processos e ter as pessoas certas para inovar se não criar condições para que a inovação realmente aconteça.

Fonte: Adaptado de Tidd; Bessant; Pavitt, (2008) 
A gestão das pessoas, dos processos, do capital intelectual e de como agir, é a principal forma de elevar o valor das empresas, até mesmo por ser hoje uma grande dificuldade, em relação às organizações, a sua capacidade de mensurar seus ativos intangíveis. Os autores relatam que para ser aproveitado todo potencial de inovação, a organização deve ter uma interação contínua e dinâmica entre o conhecimento tácito e o explícito que possui.

\section{CONCLUSÕES}

No decorrer deste trabalho foram alocadas idéias de vários autores acerca da gestão da inovação, que envolvem também a formação do conhecimento e a inovação. $O$ trabalho permitiu identificar, dentre as práticas de inovação e gestão descritas na literatura, quais podem ser aplicáveis às empresas de forma empírica, bem como suas principais formas de abordagem e vantagens percebidas. Entretanto, não foi possível concluir o quanto a utilização dessas práticas contribui para o sucesso do desenvolvimento da inovação nas empresas.

Com relação ao desenvolvimento do trabalho como um todo, o resultado obtido pode ser considerado positivo, porém faz-se necessário uma segunda etapa, a estruturação de uma pesquisa de campo de forma a identificar empresas que apliquem e levem a frente a implementação da inovação em suas atividades fins.

A busca pela inovação tem riscos, ou seja, o processo não garante sucesso automaticamente. A atividade de inovar é carregada de incertezas, com muitas variáveis, entre elas a tecnologia em si, a natureza da competição, o contexto do mercado onde será lançada e também o contexto político e social em que a organização está inserida.

Nesse sentido, também é interessante investigar melhor quais ferramentas contribuem para a etapa de aprendizagem do processo de inovação, uma vez que essa etapa é vista como importante para o processo, porém as empresas não tem a utilização de ferramentas de inovação como uma estratégia vantajosa em curto prazo. 


\section{REFERÊNCIAS}

ARAÚJO, Luis César G. de. Organização, sistemas e métodos e as tecnologias de gestão organizacional. 4 ed. São Paulo: Atlas, 2008.

BARNEY, J. B. Gaining and Sustaining Competitive Advantage. Prentice Hall, 2002. BESSANT, John; TIDD, Joe. Inovação e empreendedorismo. S/L: bookman, 2009.

CHIAVENATO, Idalberto. Empreendedorismo: dando asas ao espírito empreendedor: empreendedorismo e viabilidade de novas. 2.ed. rev. e atualizada. São Paulo: Saraiva 2007.

CHESBROUGH Henry W.. APPLEYARD Melissa M.. California Management Review VOL. 50, NO. 1 FALL 2007.

Christensen, Clayton M.. O Dilema da Inovação - Quando as novas tecnologias levam empresas ao fracasso. São Paulo: Saraiva 2012.

CUNHA, M. I. (et al). Inovações pedagógicas na formação inicial de professores. In:FERNANDES, C.M.B (Org). Educação Superior: Travessias e Atravessamentos. Canoas: Ed ULBRA, 2001.

DAVILA, Tony; EPSTEIN, Marc J.; SHELTON, Robert. As Regras da Inovação. São Paulo: Ed. Artmed, 2007.

GIL, Antonio Carlos. Como elaborar projetos de pesquisa. 4. ed. São Paulo: Atlas, 2008. DRUKER, Peter Ferdinand. Inovação e espírito empreendedor. Editora Pioneira, 1987.

GOVINDARAJAN, Vijay; TRIMBLE, Chris. Inovação Reversa: Descubra as oportunidades ocultas nos mercados. Campus - Rj, 2012.

IBGE. Pesquisa Industrial de Inovação Tecnológica - Pintec 2003. Rio de Janeiro, 2005.

JUNIOR, F. N.; NASCIMENTO, D. E. Fatores Locais para Geração de Inovação na Economia do Conhecimento. XII SIMPOI Anais... CD-ROM. São Paulo, 2009.

MOTA, R. O papel da inovação na sociedade e na educação. In: COLOMBO, S.S. (Org). Desafios da gestão universitária contemporânea. Porto Alegre: Artmed, 2011.

TIDD, J.; BESANT, J.; PAVITT, K. Gestão da inovação. 3. ed. Porto Alegre: Bookman. 2008.

Vettorato, Jardel Luís, Lei de Inovação Tecnológica - Os aspectos legais da inovação no Brasil, disponível em: http://www.buscalegis.ufsc.br/arquivos

/LEI\%20DE\%2OINOVACAO\%20TECNOLOGICA_

Os\%20aspectos\%20legais\%20da\%20inovacao\%85.pdf, Acessado em 23 de Março de 2017. 


\section{Sobre a Organizadora}

\section{Maria Aparecida Fernandes}

Graduada em Administração pela Universidade Federal de Lavras - UFLA (2011) e em Gestão de Comunicação Integrada Jornalismo pela Pontifícia Universidade Católica de Minas Gerais - PUC Minas (2003). Especialista em mídia eletrônica pelo UNIBH. Tem experiência na área de Comunicação, com ênfase em jornalismo e produção gráfica. Coordena projetos ? radialismo, comunicação, produção literária. Em administração, atua principalmente na elaboração e gestão de projetos de pesquisa e inovação na área de bioengenharia, educação e desenvolvimento social e econômico.

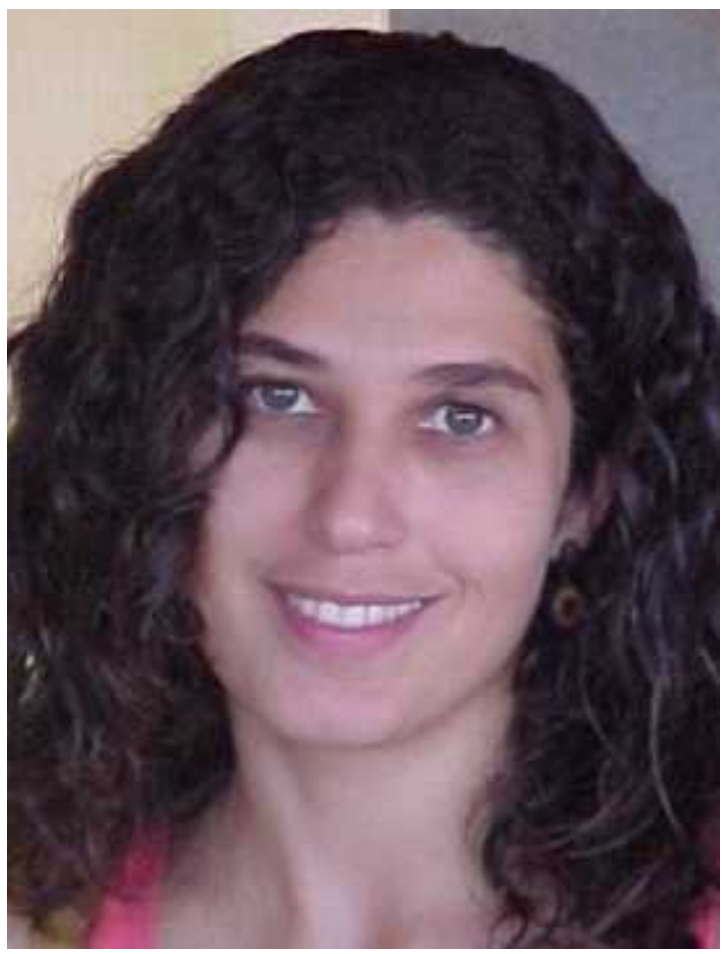




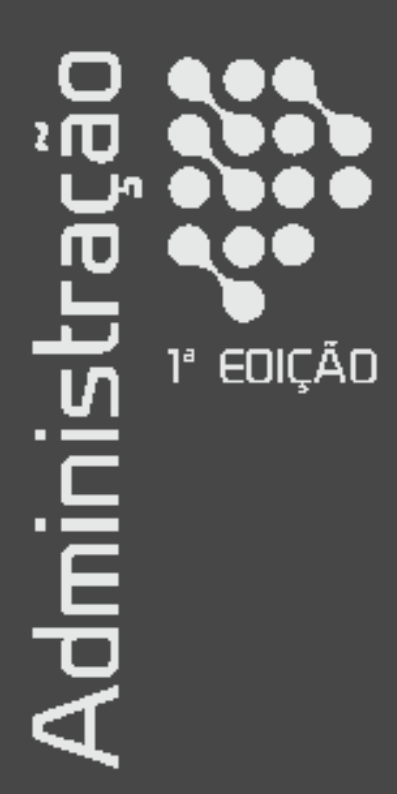

5 https://www.facebook.com/Synapse-Editora-111777697257115

(C) https://www.instagram.com/synapseeditora

in https://www.linkedin.com/in/synapse-editora-compartilhando-conhecimento/

(C) $3198264-1586$

editorasynapse@gmail.com

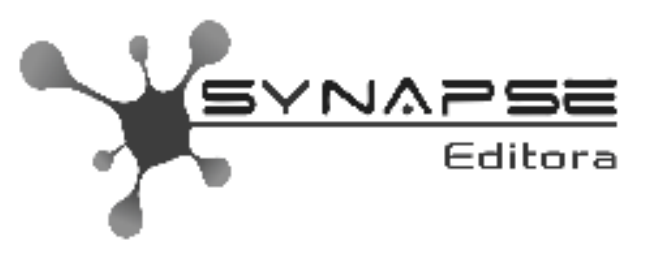

Compartilhando conhecimento 